\title{
Stratigraphic analysis of the Bahia intraslope basin, offshore northern Colombia
}

By

\section{ARIAN MAURICIO SARMIENTO-ORJUELA}

B.A., Geological Sciences, Universidad Nacional de Colombia, 2011

A thesis submitted to the

Faculty of the Graduate School of the

University of Colorado in partial fulfillment

of the requirements for the degree of

Master of Science

Department of Geological Sciences

2019 
This thesis

entitled:

Stratigraphic analysis of the Bahia intraslope basin, offshore northern Colombia written by Arian Mauricio Sarmiento has been approved for the Department of Geological Sciences

\section{Dr. Paul Weimer}

Dr. Tomas Villamil

Dr. Charles Stern

\section{Date}

The final copy of this thesis has been examined by the signatories, and we find that both the content and the form meet acceptable presentation standards of scholarly work in the above mentioned discipline. 
Sarmiento-Orjuela, Arian Mauricio (M. S. Geological Sciences)

Stratigraphic analysis of the Bahia intraslope basin, offshore northern Colombia Thesis directed by Dr. Paul Weimer

\begin{abstract}
The Bahía Basin is an intraslope basin in the Colombian continental slope located in the northern part of the South American Plate, in a structurally and stratigraphically highcomplexity zone due to the interaction between the Caribbean and South American Plates. During the Neogene, the basin evolved associated with a transform margin.

Three main tectono-sequences (TS1 to TS3) characterize the Cenozoic stratigraphic evolution. TS1 consisted of deformed strata that underlie the prospective sequences. The transtension stage occurred during the deposition of TS2, which consist of six main sequences (S1 to S6). Each sequence has varying thickness, in part due to the syndepositional structuring the basin. The basin developed onto a pre-structured topography, defined by the thrusting stage during TS1. Three sub-basin comprise the Bahia Basin, and basin-fill consisted of intraslope turbidite system, including channel-fill, lobes and levee sediments. The Araza-1 well, flanking the basin penetrated reservoir quality sand with gas shows.

TS3 developed after a major transpressional stage. This transpression inverted the basin, and created several potential anticline traps, underlying by reverse faults, and in echelon structures. The presence of gas shows suggest an active petroleum system. The Bahia basin is an attractive frontier exploration area.
\end{abstract}




\section{ACKNOWLEDGEMENTS}

Firstly, I want to thank my advisor Dr. Paul Weimer for his guidance and patience throughout my graduate time, and especially for support me in my search for contributing to the knowledge of the Colombian Caribbean. This experience gave me more elements to follow this path to be an excellent interpreter.

I am very grateful to Dr. Tomas Villamil for guidance, comments and valuable discussions in my work. All his generous contributions complement in a superlative way my research goals.

Additional I would like to especially thanks to ECOPETROL S. A. particularly to Offshore Colombia Area (Jorge Calvache, John Londoño, Juan Carlos Llinas, Oswaldo Mantilla, Helga Niño, David Izquierdo, Catalina Ramirez, Victor Sotelo, David Sanabria and so on) for providing all data used for this research, and for the permission to publish this thesis. IHS Kingdom Suite Software and Services, is acknowledged for providing the software used to interpret the seismic data under a university software grant to Imperial College. I am greatly indebted to my dad Dr. Gustavo Sarmiento to be my support in geology pathway and my model of geologist walkway. His recommendations, guidance and support make me a better geologist during all these years

Thanks to my mother Luz Angela, my sisters Lina y Daniela and my fiancée Erika that play a very important role in helping me get through the long stretches. Their patience understanding and love to helped me get through the long pathway of hard times living abroad.

Thanks to all the new friends (Luke, OAT and Postal) and colleagues at Colorado University for great times and experiences. To all my friends in Colombia who always sent 
me their blessings and good vibes. I am very grateful to Carolina Mayorga, Carolina Mejia, Laura Rodriguez, Martha Perdomo and Diego Sanchez for letting me make his home, in different places that I visited in the US. To Santiago Valderrama to be as a brother when we lived in US to get through hard times in Boulder. 


\section{CONTENT}

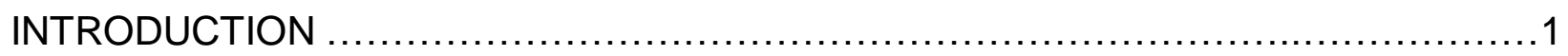

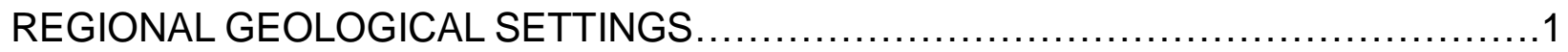

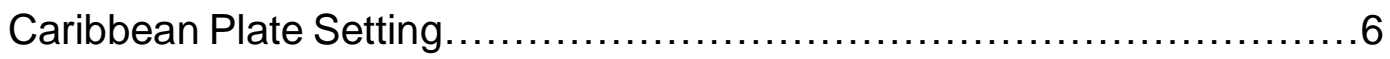

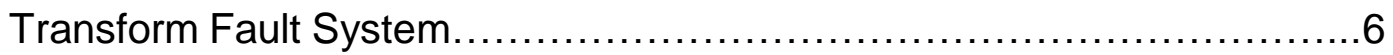

Accretionary Fold Belts..............................................

Stratigraphy and Magdalena Fan Delta................................

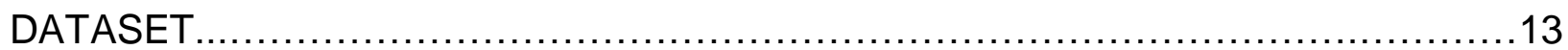

Seismic 3D..........................................................

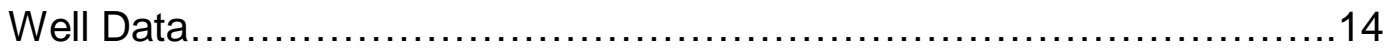

INTERPRETATION AND METHODOLOGY ............................................ 14

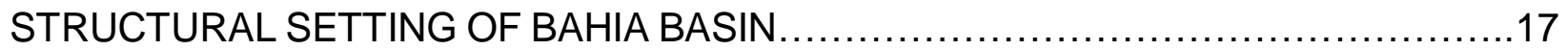

Strike-Slip Fault.....................................................18

Normal Faults........................................................ 19

Normal Minor Faults......................................................

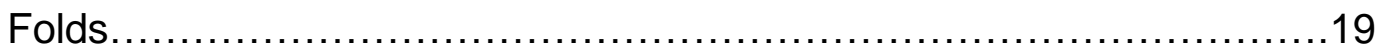

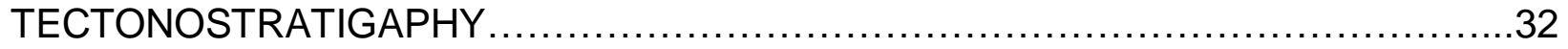

Tectono-sequence 1 (TS1) ...........................................

Tectono-sequence 2 (TS2) ..........................................

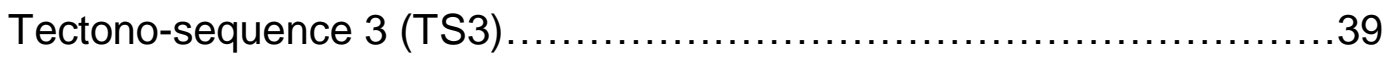

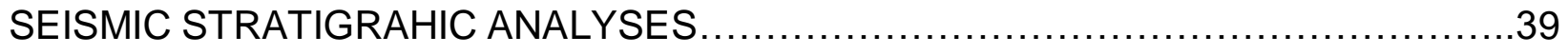

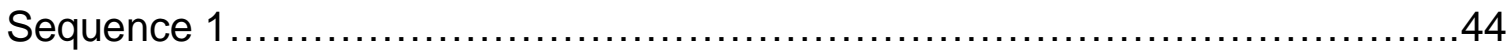

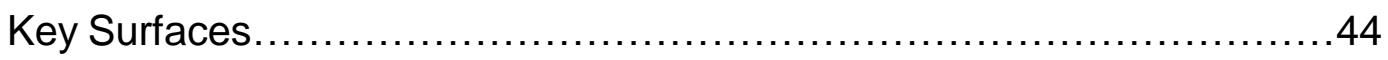


Time-Structure Map................................................. 44

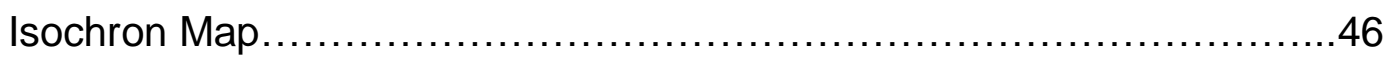

Seismic Facies......................................................... 46

Geologic Interpretation.............................................. 47

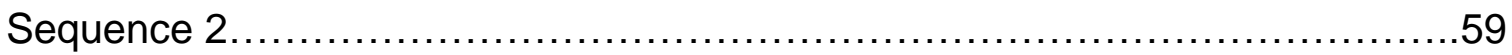

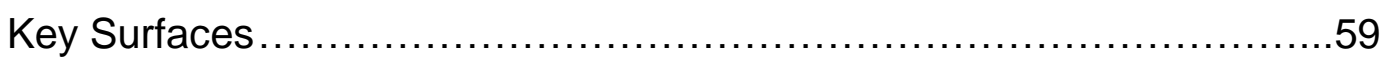

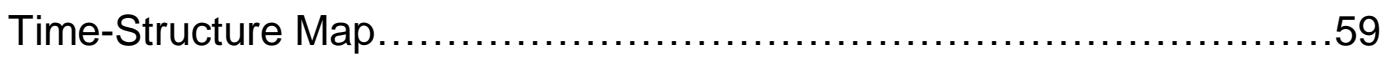

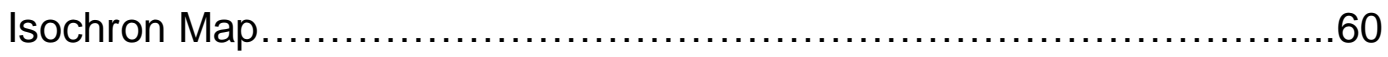

Seismic Facies.........................................................

Geologic Interpretation................................................

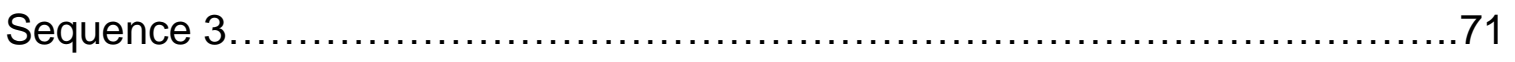

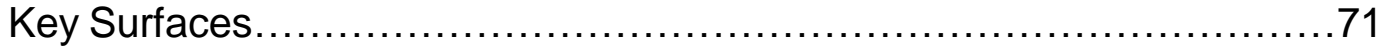

Time-Structure Map................................................... 72

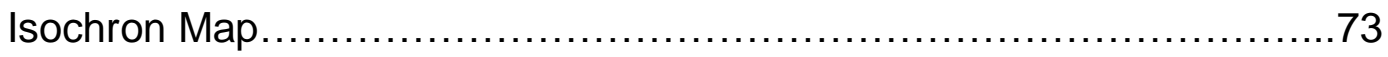

Seismic Facies........................................................

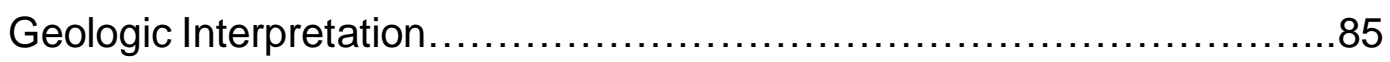

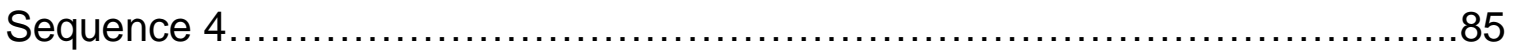

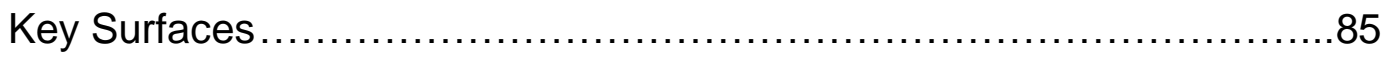

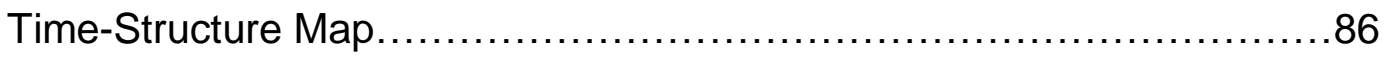

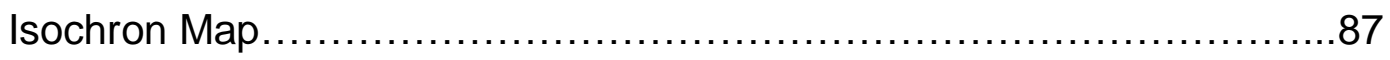

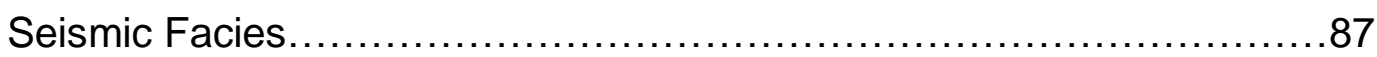

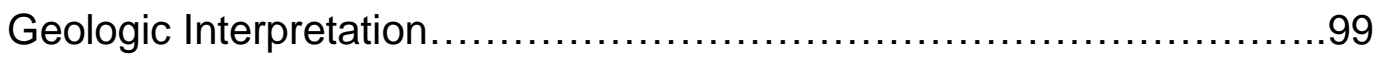

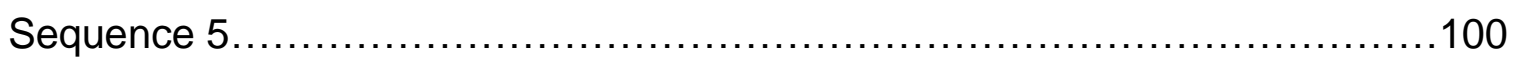


Key Surfaces ......................................................... 100

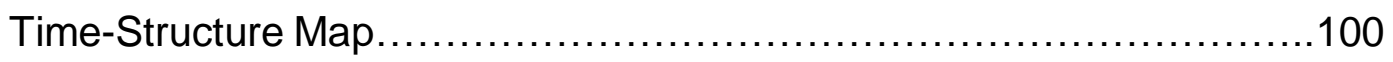

Isochron Map...................................................... 101

Seismic Facies .................................................... 102

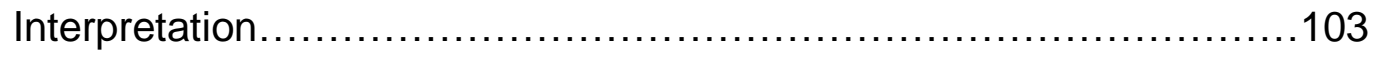

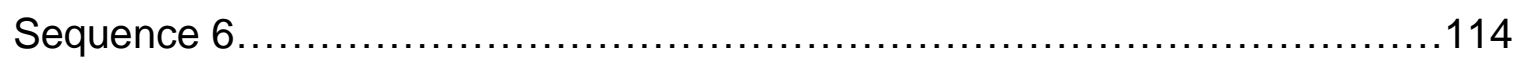

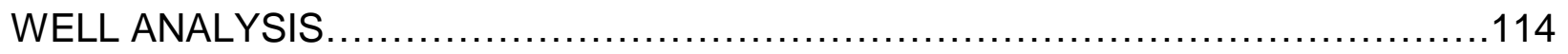

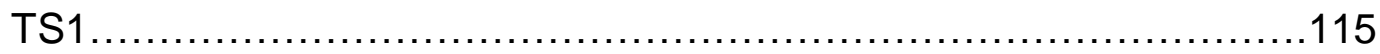

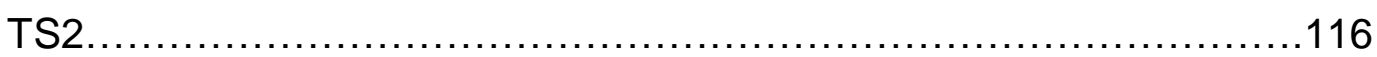

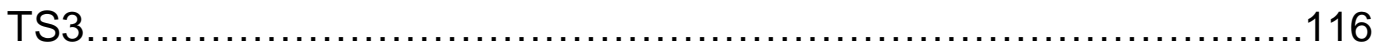

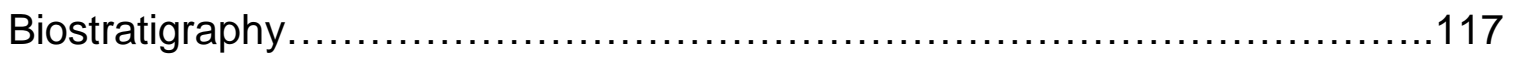

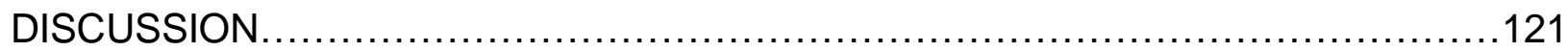

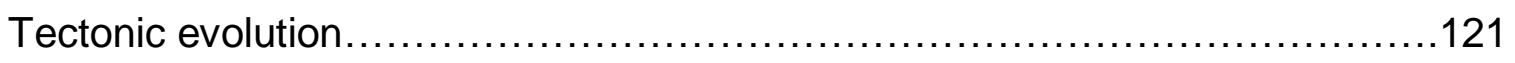

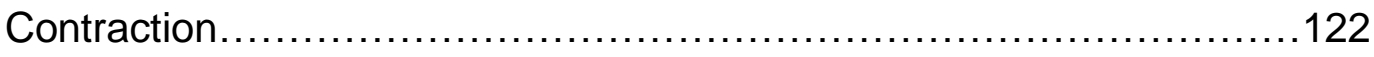

Transtension and Filling ............................................... 122

Inversion, Erosion, and Gravitational Fault............................122

Stratigraphic - structural evolution of the Bahia Basin ...........................123

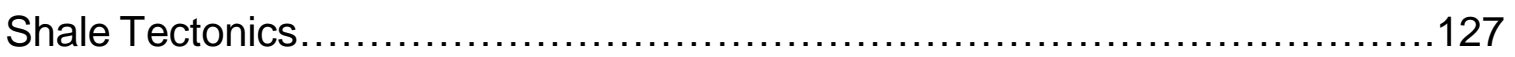

Petroleum System Elements: Assessment of Hydrocarbon Potential ...........127

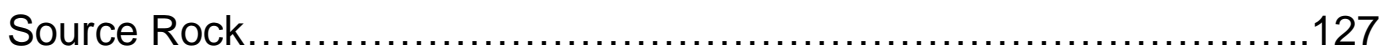

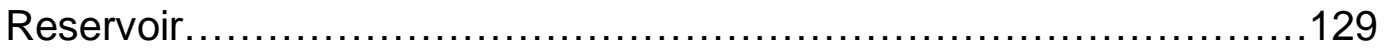

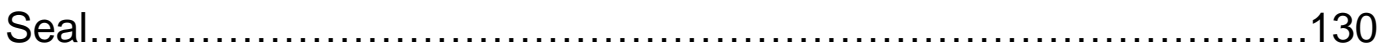

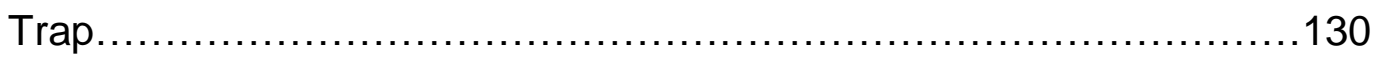




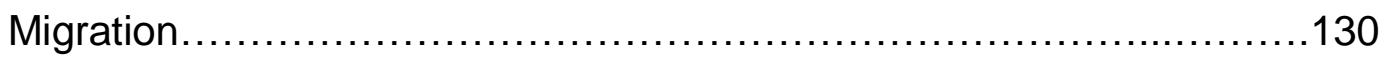

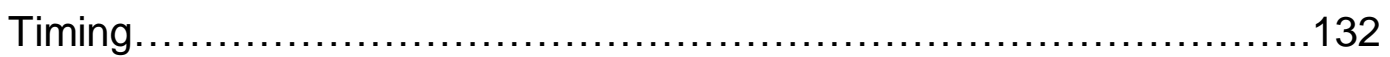

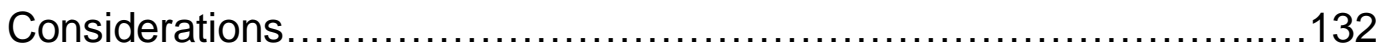

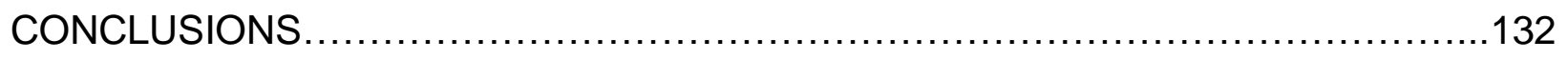

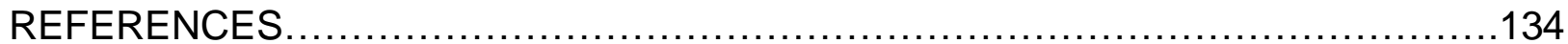




\section{FIGURES}

1. Location of study area, offshore Bahia Basin.....................................

2. Bathymetry and data acquired in northern Colombia ..............................

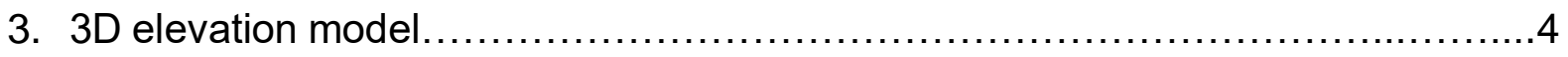

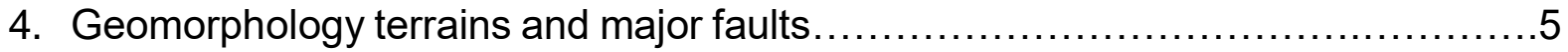

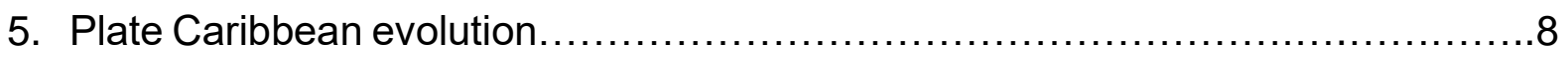

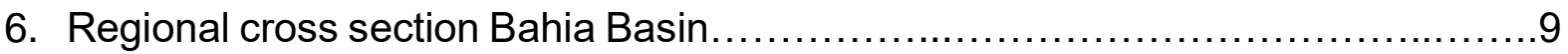

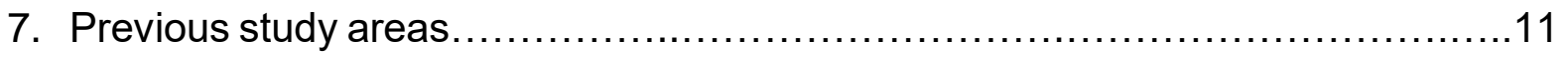

8. Lithostatigraphy Schedule...................................................... 12

9. Cross line and time slices effects of footprint removal..........................15

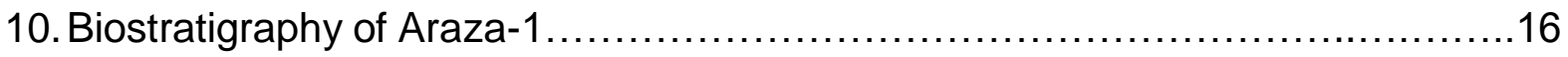

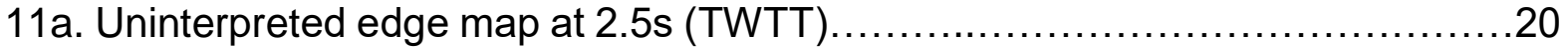

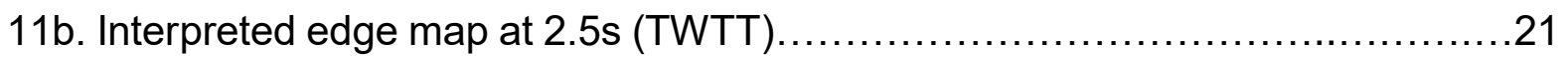

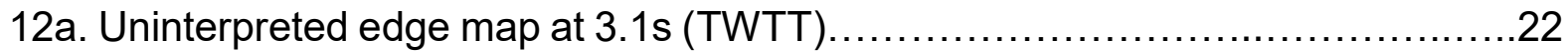

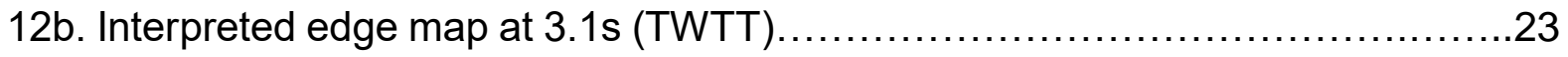

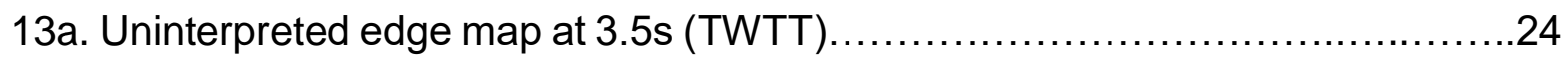

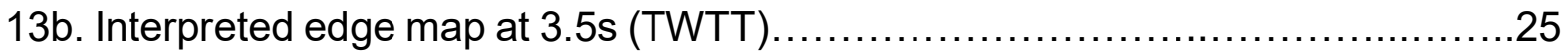

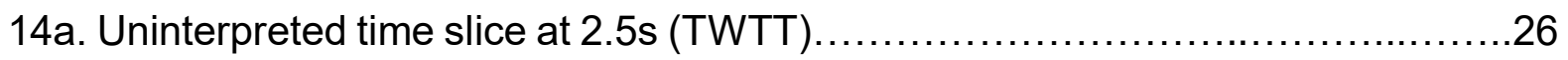

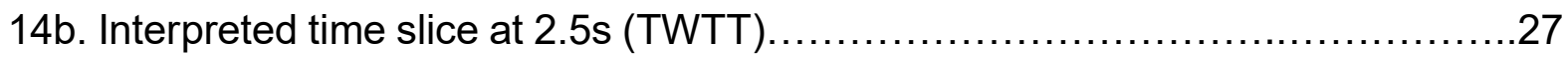

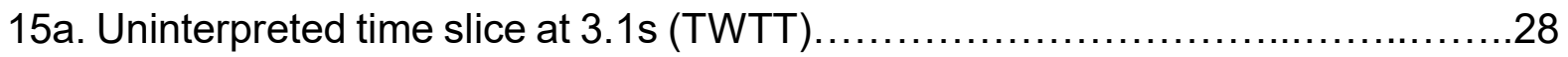

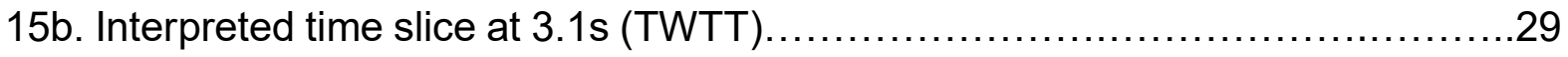

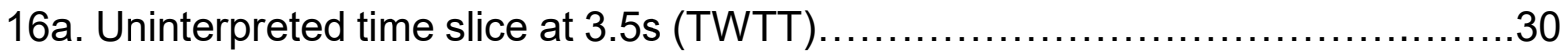

16b. Interpreted time slice at 3.5s (TWTT) ......................................... 
17. Seismic profile across SubB 1 and 2, tectono-sequences.......................34

18. Seismic profile across SubB 2 and 3 , tectono-sequences.......................35

19. Seismic profile across SubB 1 - Araza High, tectono-sequence....................36

20. Seismic profile across SubB 3 - Araza High and tectono-sequences ...............37

21. Seismic profile across SubB 1 and 2, TS2 distribution...........................40

22. Seismic profile across SubB 1 - 2, TS2 distribution ............................41

23. Seismic profile across SubB 2 - 3, TS2 distribution ...........................42

24. Seismic profile across SubB 1 - Araza High, TS2 distribution......................43

25. Seismic profile across SubB 3 - Araza High, TS2 distribution .....................44

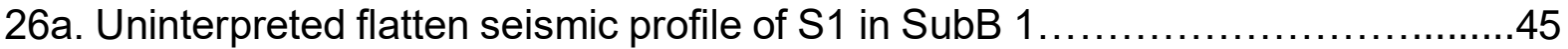

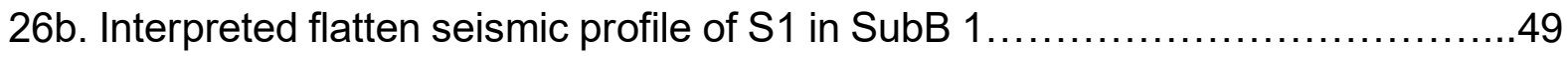

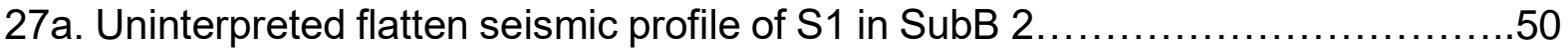

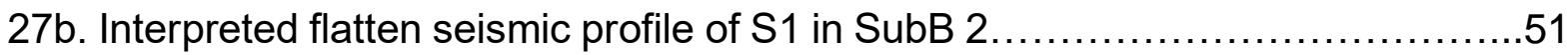

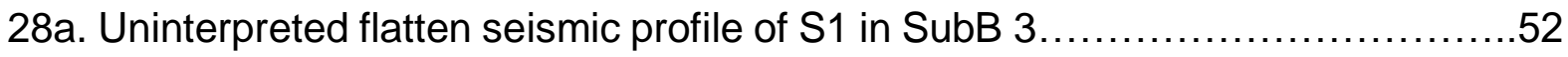

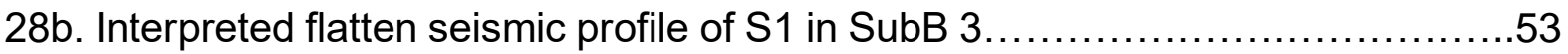

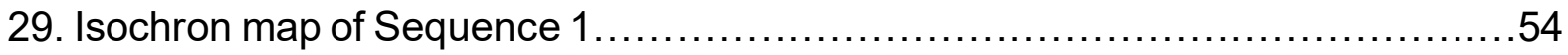

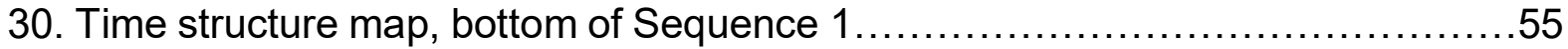

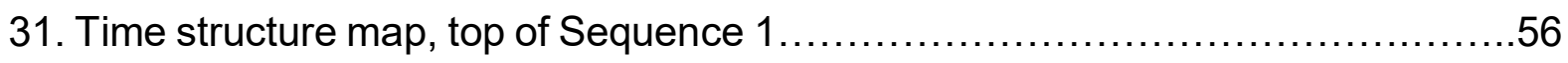

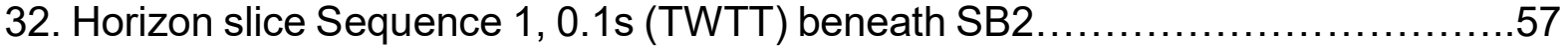

33. Horizon slice Sequence 1, 0.4s (TWTT) beneath SB2 ........................58

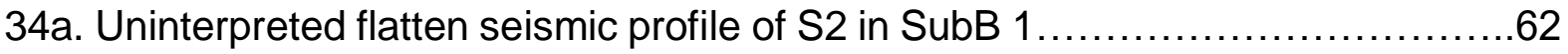

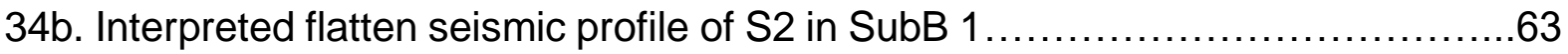

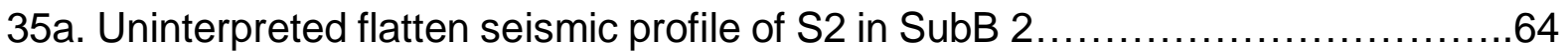




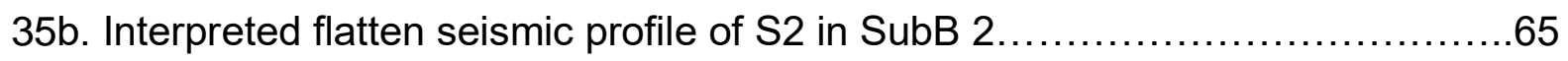

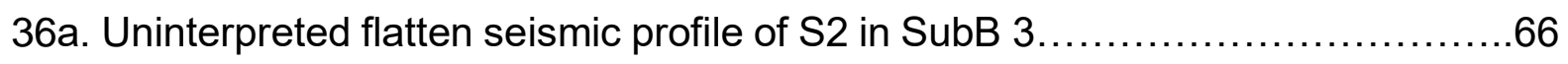

36b. Interpreted flatten seismic profile of S2 in SubB 3.............................67

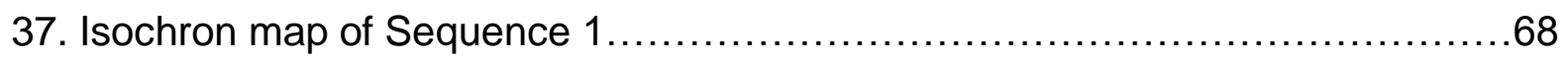

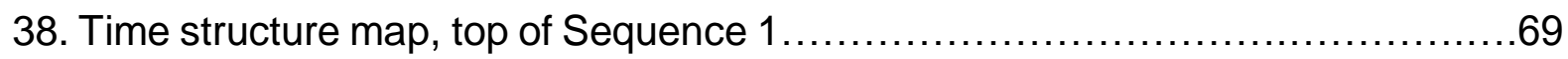

39. Horizon slice Sequence 1, 0.2s (TWTT) beneath SB3 ........................70

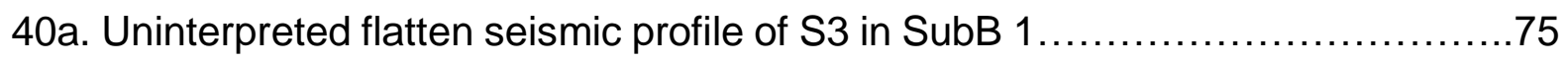

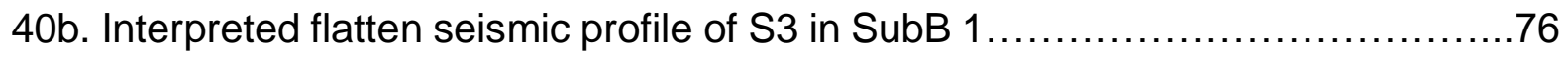

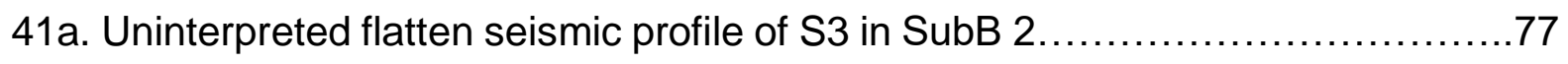

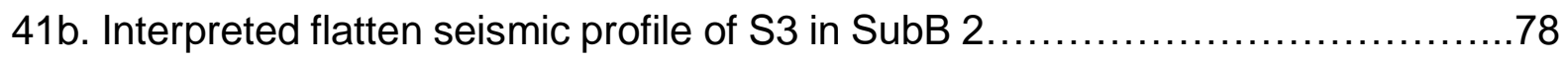

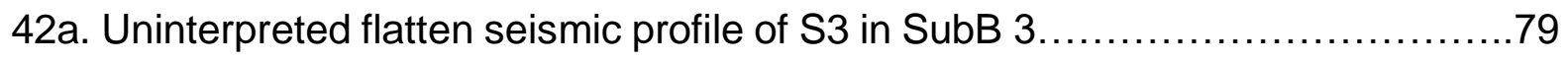

42b. Interpreted flatten seismic profile of S3 in SubB 3 ............................. 80

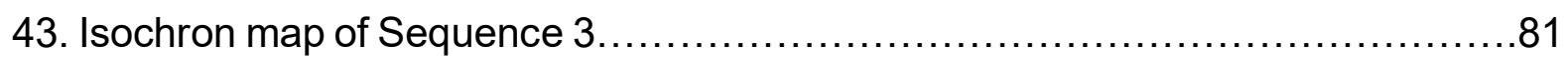

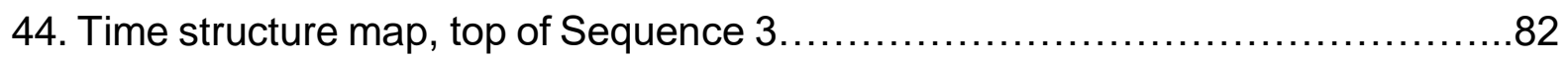

45. Horizon slice Sequence 3, 0.1s (TWTT) beneath SB4 .......................... 83

46. Horizon slice Sequence 3, 0.2s (TWTT) beneath SB4 ..........................84

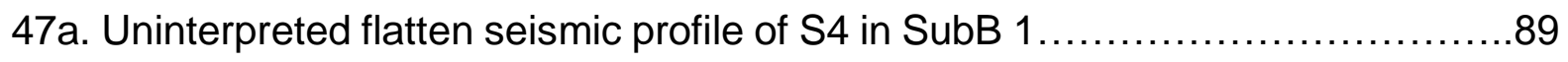

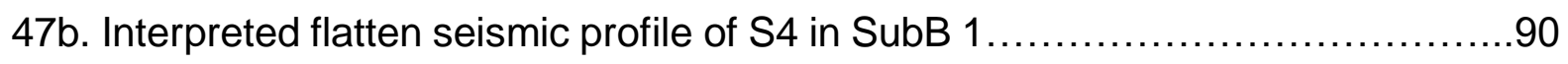

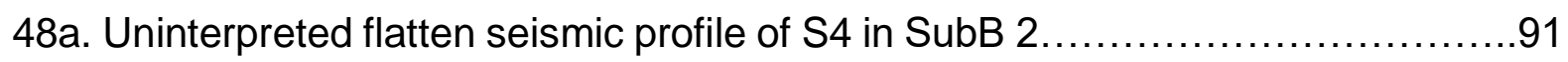

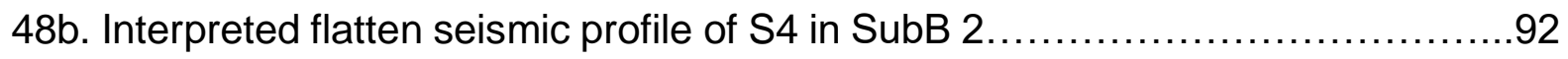

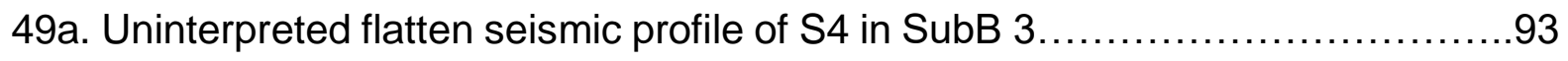

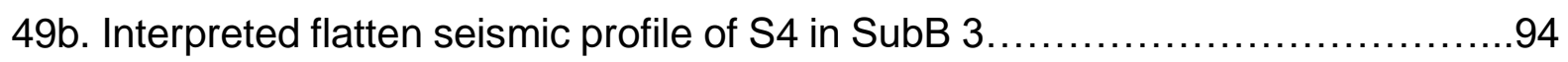

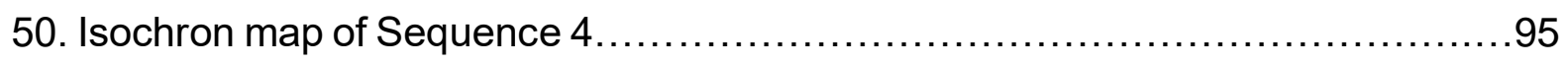




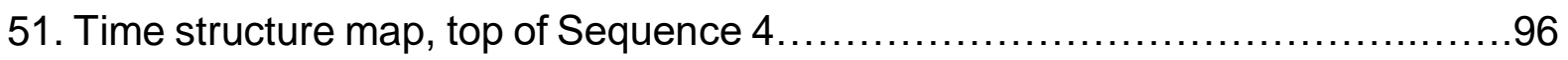

52. Horizon slice Sequence 4, 0.05s (TWTT) beneath SB5 ........................97

53. Horizon slice Sequence 4, 0.1s (TWTT) beneath SB5 .........................98

54a. Uninterpreted flatten seismic profile of S5 in SubB 1.......................104

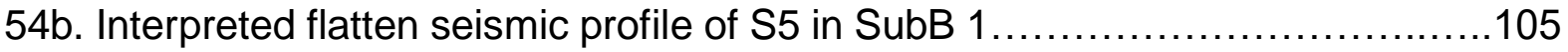

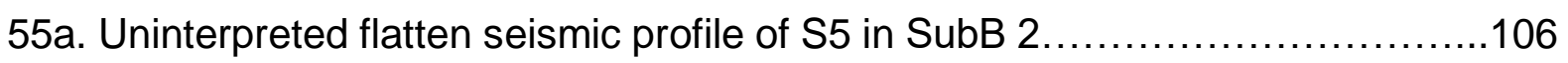

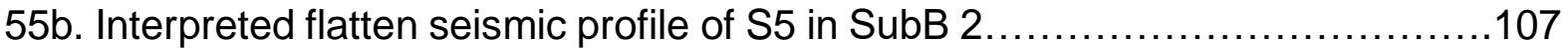

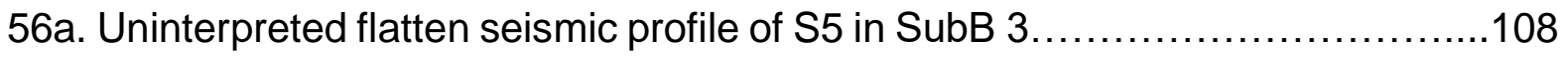

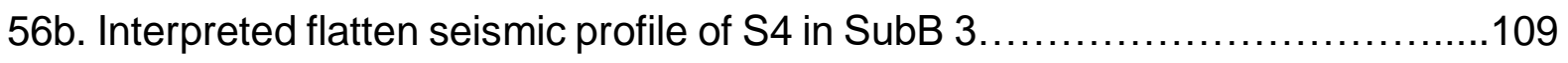

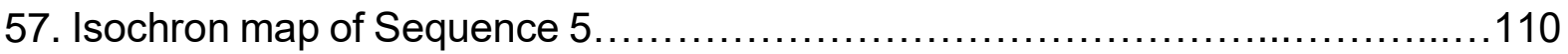

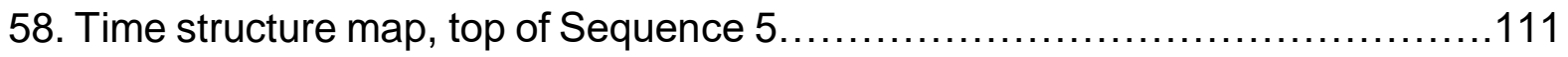

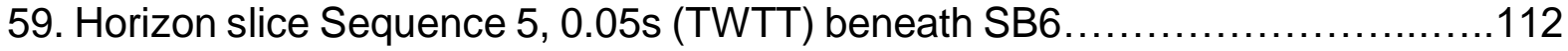

60. Horizon slice Sequence 5, 0.1s (TWTT) beneath SB6 ........................113

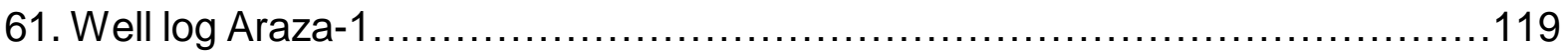

62. Chronoestratigraphic Chart..................................................

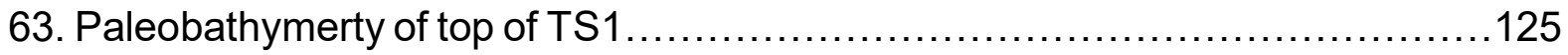

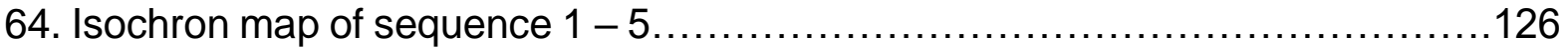

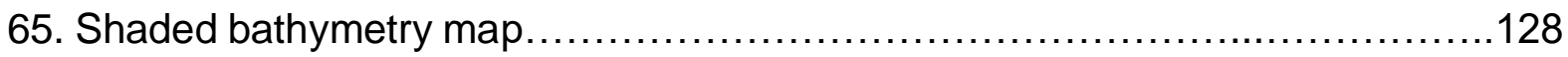

66. Seismic profile, possible flat and bright spots..................................131 


\section{INTRODUCTION}

The Bahía Basin is intralope basin located in the Colombian Caribbean Margin (CCM), to the northeastern edge of the South America Plate (Figures 1 - 3). The basin was created from the complex tectonic interaction of the Caribbean Plate and Nazca Plate (Figure 1). The general area has had active exploration for the last 60 years, and is considered to a gas prone with potential.

The continental slope is highly structured, and the Cenozoic sedimentary fill was derived primarily from Magdalena Delta. The Bahia Basin is largely a frontier exploration area, with only one well drilled in the area. The presence of sand in the well, plus abundant and gas shows, potential structures in the basin, make this area a potential exploration province. The objectives of this thesis is to evaluate the petroleum potential of the area by interpreting a 3D data set. First, the sequence stratigraphy and structural framework

will be defined. Second, the reservoir potential of each sequence is interpreted using seismic attributes. Third, the other elements of the petroleum system will be evaluated to assess the exploration potential of the basin.

\section{REGIONAL GEOLOGICAL SETTINGS}

The Bahía Basin was deposited in a complex active margin above the continental north South American plate, which interacts with the south oceanic Caribbean plate. It is adjacent to the San Jacinto Sinu sedimentary prism and San Jorge sedimentary basin (Figure 4). The major geologic features are reviewed first, followed by chronology of events. The major geomorphologic terrains in northern, Colombia and the continental slope are shown in Figure 4; the deep-water basin sits at north of the subduction zone 


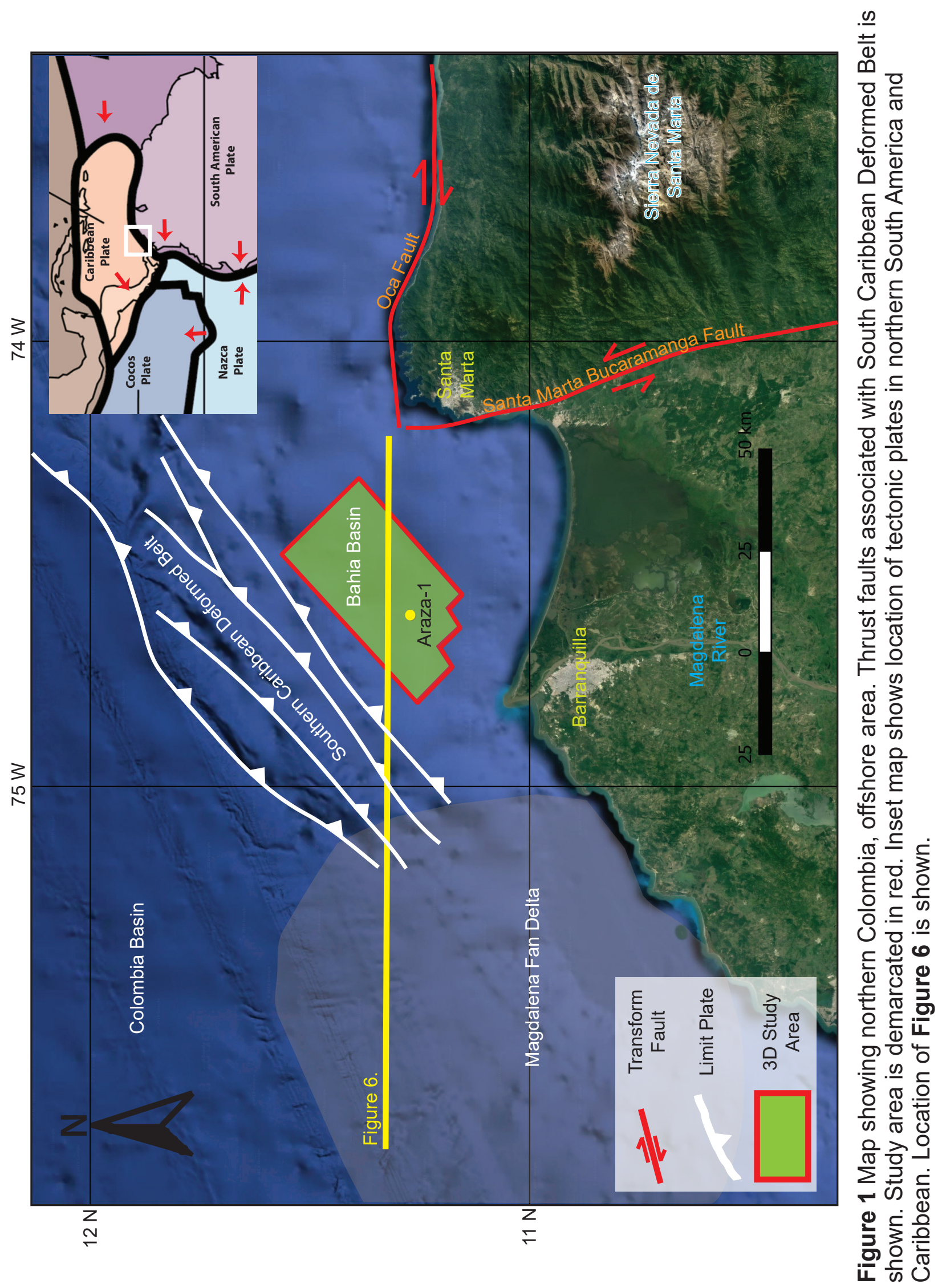




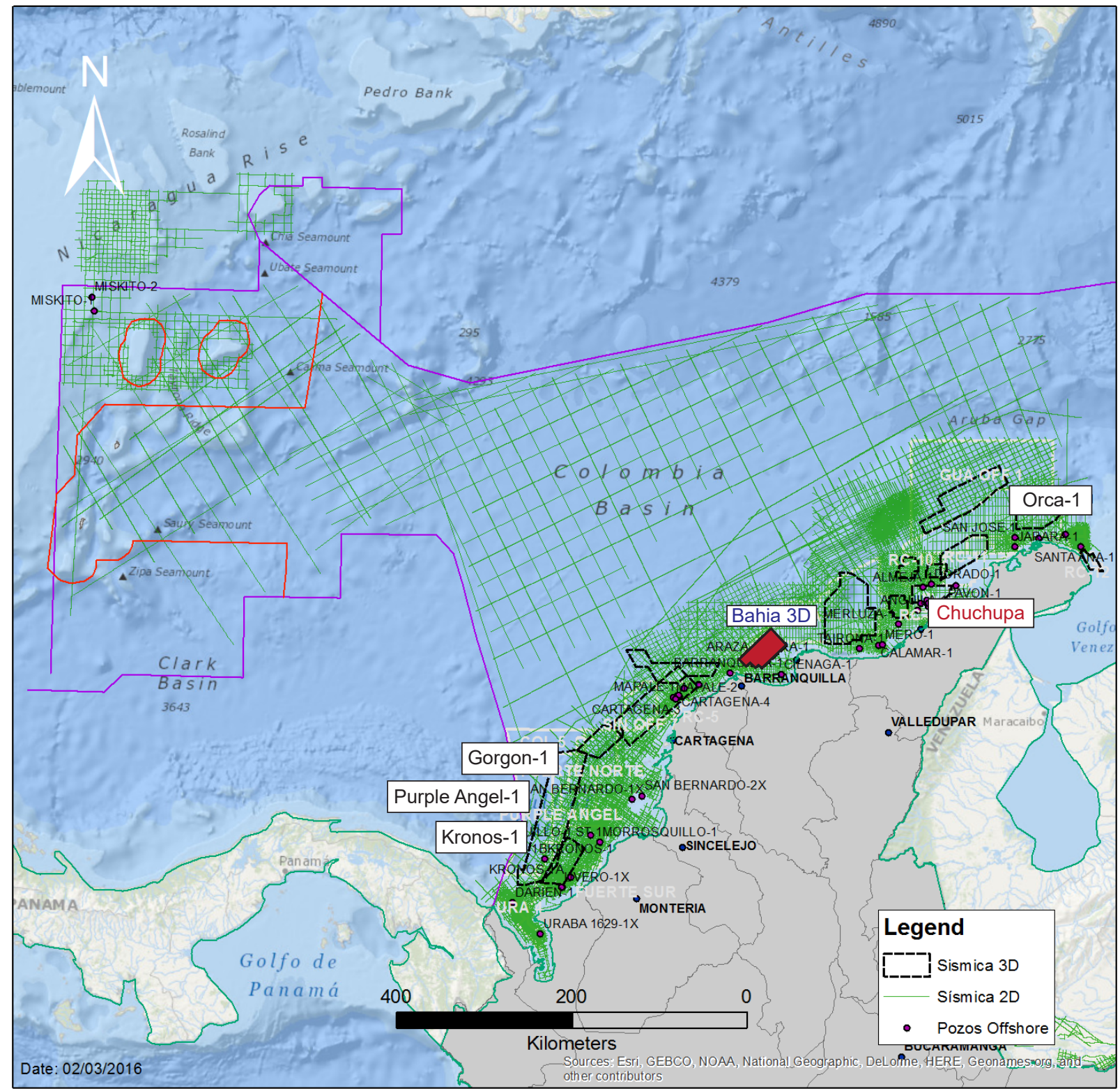

Figure 2. Map of northern Colombia and bathymetry of the South Caribbean showing the data acquired in the CCM. Green lines show 2D seismic data and dashed lines show 3D seismic data. In black the most recent gas discoveries. In red the Chuchupa Field Gas in the northern part of Colombia. 


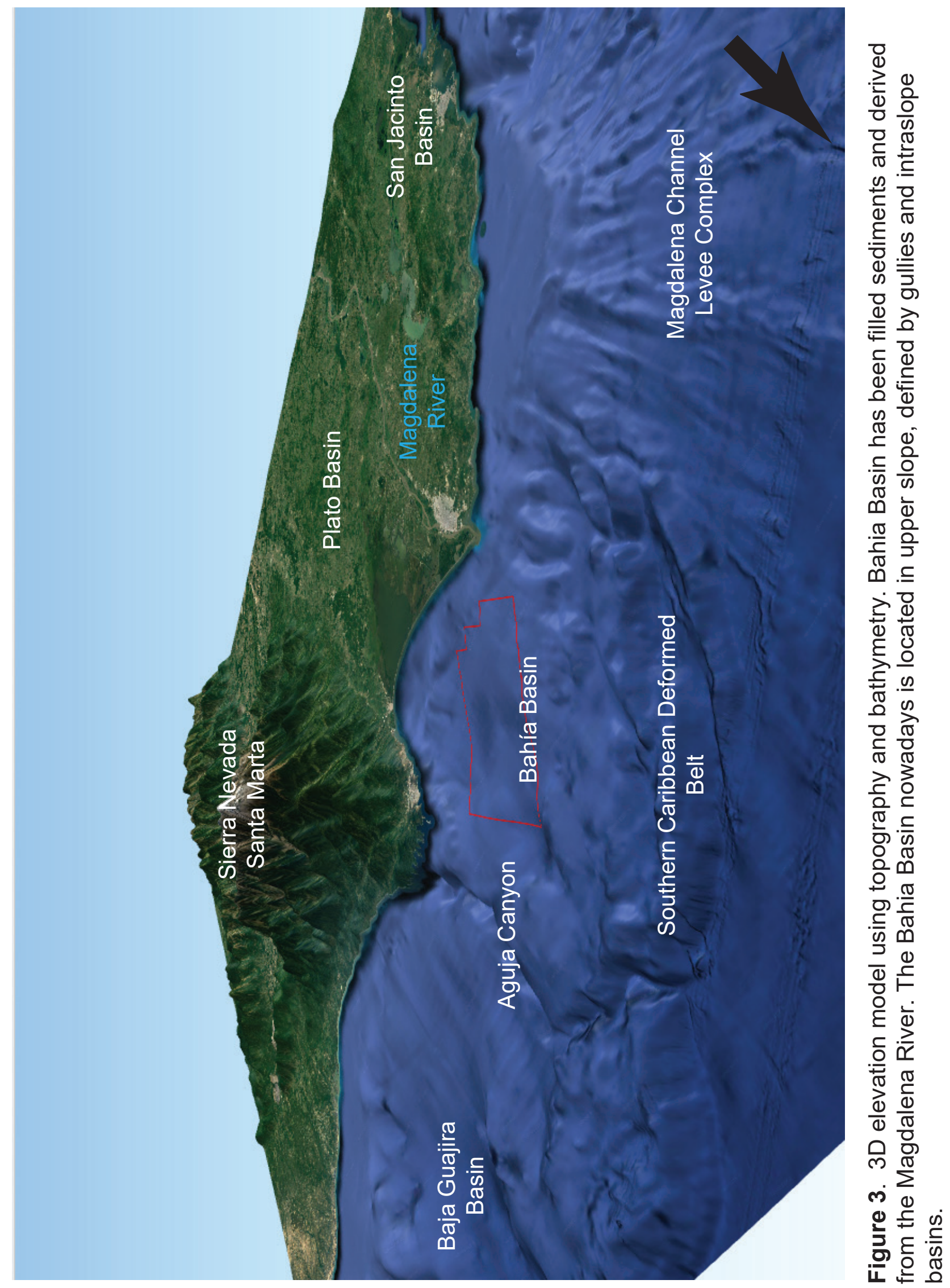




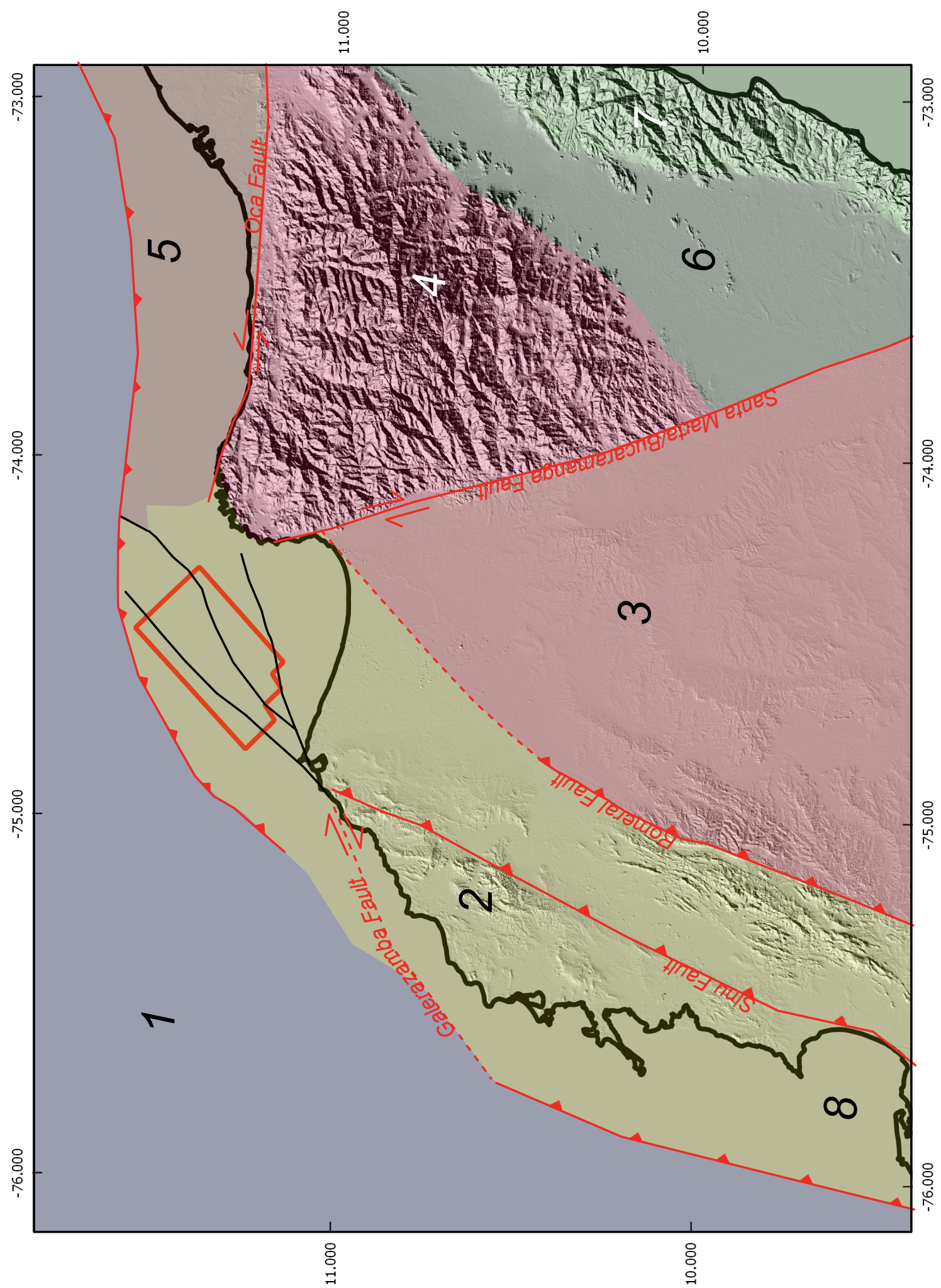

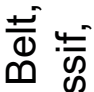

율

过 :

든

ஸे

음

고

क .

ㄴ

$\frac{5}{\mathrm{~S}} \frac{\mathrm{C}}{\mathrm{N}}$

๘

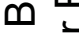

쥬

을

- 응

인

- 这

我

흠

है :

তั ญ

क $\pi$

:

- $\sum^{2} \frac{\pi}{2}$

응 䎡

응 잉

은 증

ह

ঠั

든 은 응

है ज

이응

造

을 $\frac{1}{\infty}$

음

$\sum$ 임

ษ 웅

๖ำ 즌

음 ণั

ப 
(Figure 4). The study area is in the northeastern part of the San Jorge Basin and Sinu San Jacinto deformed belts. Four major onshore provinces are present surrounding the study area: Sierra Nevada Massif, Guajira area, Cesar Rancheria Basin and Perija Massif. The edges between the provinces are fault bounded.

\section{Caribbean Plate Setting}

During the early Neogene period, the Caribbean Plate changed abruptly from a northward movement to eastward (Pindell and Kennan, 2009) (Figure 5), generating an oblique collision until recently, causing a transpressional strain along the Venezuela and north Colombia areas. Major strike-slip faults are the main structural components for the Bahía evolution. These faults lie behind the toe of the modern accretionary prism, where the Caribbean Plate is being subducted obliquely beneath South America (Galindo and Lonergan, 2017).

\section{Transform Fault System}

The Bahía Basin is located in front of the termination of major regional strike-slip faults (Oca - Santa Marta/Bucaramanga), and is likely associated to the strike-slip faults that cross the basin. The Oca Fault is a right lateral strike-slip fault with an extension of 650 km eastwards, and together with strike-slip faults in the Bahía Basin controlled the evolution of the basin during the early Paleogene (Galindo, 2015). The Santa Marta/Bucaramanga Fault is a left lateral strike-slip fault extending $550 \mathrm{~km}$ southwards along the Eastern Cordillera and its displacement has been calculated as approximately 110 km (Campbell, 1965). 


\section{Accretionary Fold Belts}

Underlying the Bahía Basin, a prior accretionary prism was developed during the Oligocene period, correlated with the Sinu - San Jacinto Belt time accretion to the South America Plate (Galindo, 2015) (Figure 6).

The northern part of Colombia had been developed by the evolution of the San Jacinto and Sinu terrains and this evolution controls the deltaic systems in the Cenozoic (Flinch and Castillo, 2015) (Figure 4). The San Jacinto prism was accreted during the Oligocene followed by the Sinu prism during the early Miocene. These accretions caused for the major uplift phase of the northern Andes Cordillera, producing major input of siliciclastic sediments. Neogene syn-tectonic sediments fill the Caribbean Margin throughout the basin (Kolla et al., 1984; Flinch, 2003; Vinnels et al., 2010). Currently, the Sinu Offshore Prism and the South Caribbean Deformed Belt (SCDB) continue to be deformed along the Colombian Caribbean Margin, similar to the evolution of the Sinu and San Jacinto thrust belts (Vinnels et al., 2010).

The San Jacinto thrust belts uplift the Cretaceous (Guzman, 2007), and created the early Miocene piggyback basin. The Sinu thrust belts are the follow up of the San Jacinto thrust belts with early Miocene piggybacks. Finally, the SCDB was developed during the early Miocene, filled by Plio-Pleistocene sediments onto their piggybacks (Figure 6) (Flinch, 2003).

\section{Stratigraphy and Magdalena Fan Delta}

The Colombian Caribbean Margin has been strongly filled by Neogene sediments from the Magdalena River. Previous authors define the onset of the Magdalena Fan during the 

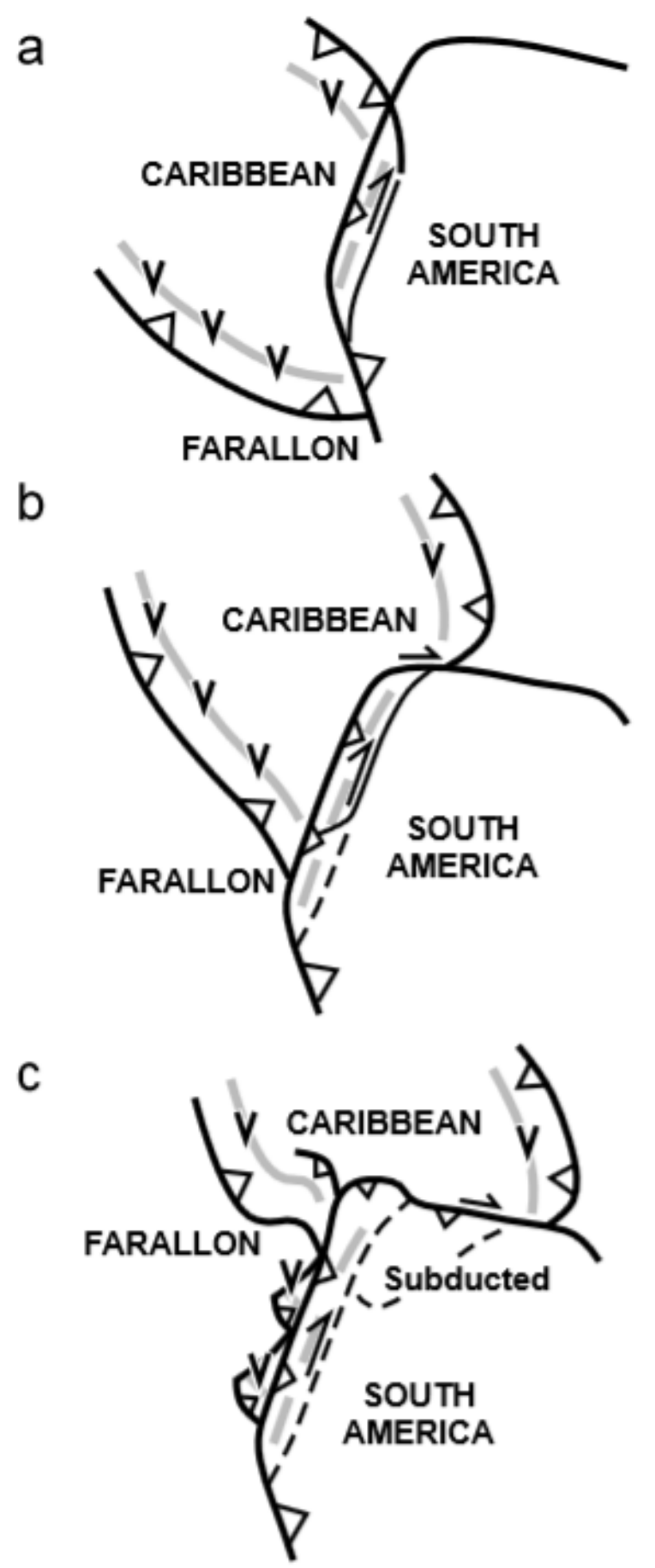

Figure 5. Plate evolution of the Caribbean:(a). Late Cretaceous, (b). Early Cenozoic and (c). Middle Cenozoic. During the Middle Miocene, the Caribbean Plate shifted its movement to the east along a strike-slip. The fault changes in plate motion caused the tectonic variations between TS1 and TS2. After Pindell and Kennan (2009) 


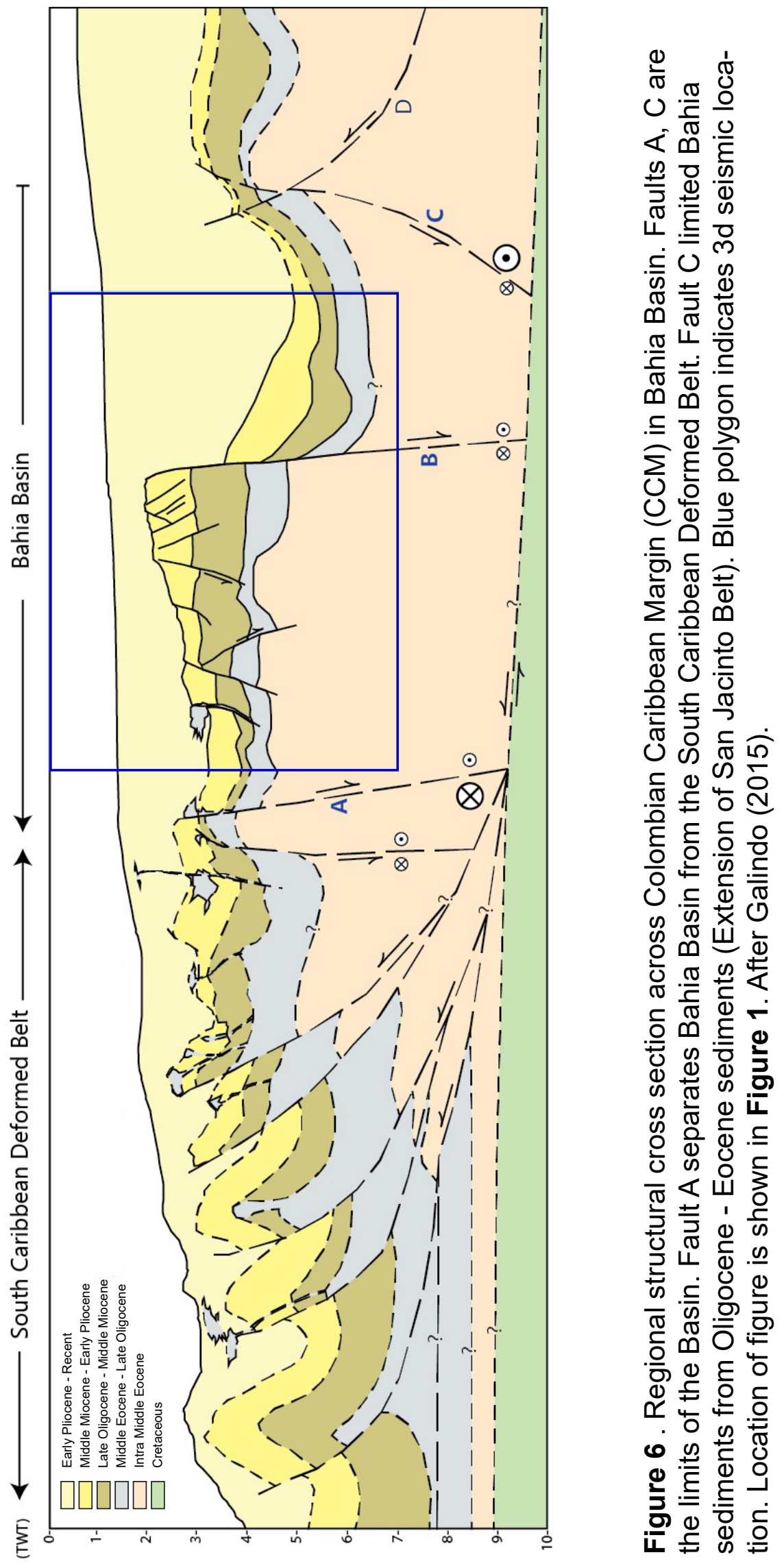


middle Miocene, overlaying a foredeep megasequence (Kolla et al., 1984; Duque-Caro, 1991; Alfaro and Holz, 2014b; Martinez et al., 2015; Romero-Otero et al., 2015).

Several studies have focused on how the evolution Magdalena of related sediments (Figure 7) during the Neogene (Kolla et al., 1984; Duque-Caro, 1991; Hoorn et al., 1995; Ercilla et al., 2002; Estrada et al., 2005; Vinnels et al., 2010; Alfaro and Holz, 2014b; Cadena et al., 2015; Martinez et al., 2015; Ortiz-Karpf et al., 2015; Romero-Otero et al., 2015). The paleo-Magdalena developed initially in the Maracaibo region during the Late Paleogene (Guerrero, 1993). During the middle Miocene, the Colombian Andes uplift generated a barrier north-trending to the west margin that re-oriented the river (Magdalena) north-system process towards the Caribbean Sea (Hoorn et al., 1995; Villamil, 1999). The highest input of Magdalena River toward the Bahía Basin of the Magdalena River was during the Pleistocene (Romero-Otero et al., 2015).

A schematic lithostratigraphy diagram (Guzman, 2007; Flinch and Castillo, 2015) correlates the northern Colombian basins with Bahia Basin (Figure 8). Plio-pleistocene conglomerate units support the high energy input of the Magdalena River to the northeastern part of South America. Muddy sediments recorded in Araza-1 represent the distal Magdalena River input, or likely associated to a barrier between the Bahía Basin and the Magdalena Delta location.

Chronologically five main events, described by Galindo (2015), characterize the area's geological process. The Caribbean Plate collision in the northwest part of South America during the late Cretaceous. The Sinu - San Jacinto Fold Belt accretion to the Continental Margin since the late Eocene. The shifting motion of the Caribbean Plate eastwards and start of oblique subduction during the early Miocene represented by strike faulting 


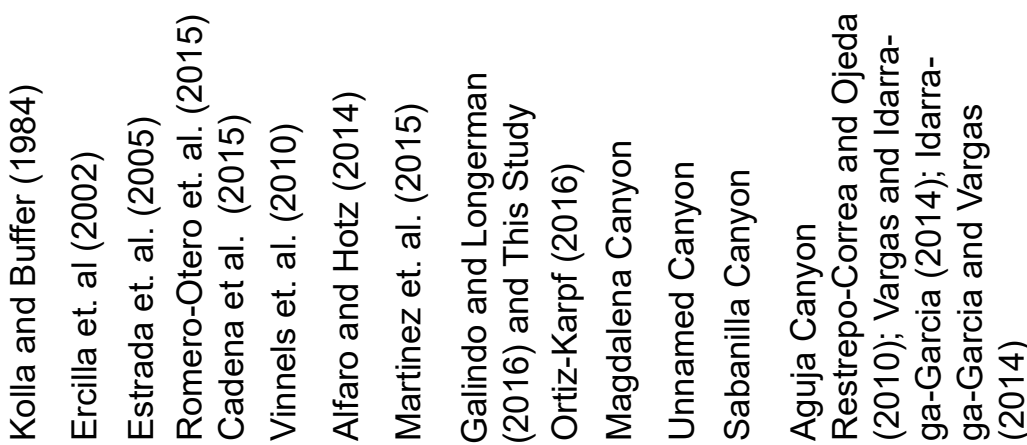

$\frac{1}{\mathbb{1}}$

ฮ্ঠে

$\stackrel{\oplus}{\rightleftharpoons}$

ธิ

里

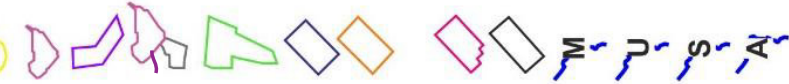

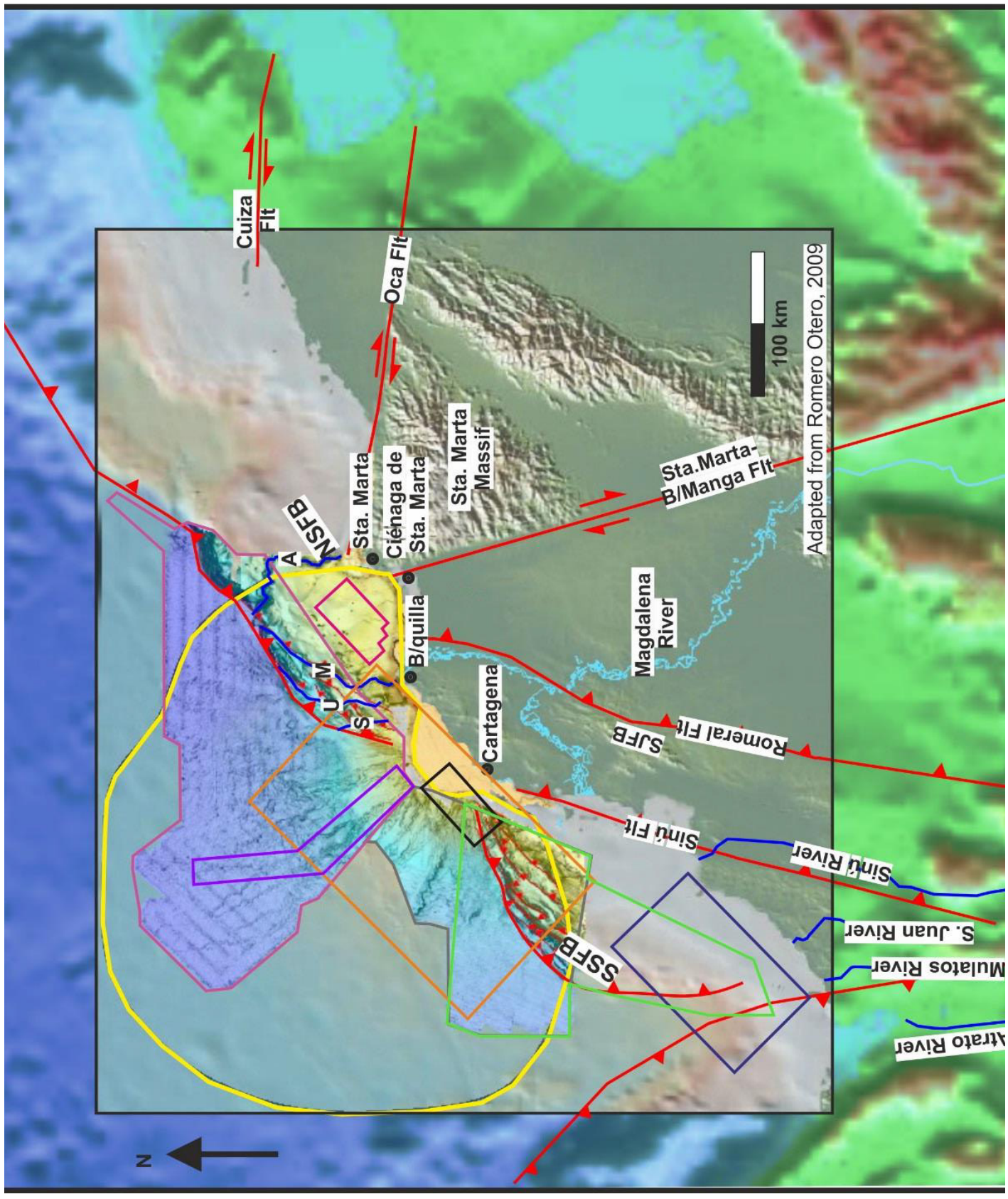

옥

प0

을 宅

응 능

문

$\sum_{0}^{\circ}$

응

$\sum_{0} \frac{\bar{d}}{4}$

U

등

도

कั তิ

$\varepsilon$

들

은

응

ฮั

$\frac{c}{\sqrt{0}} \sum^{\frac{5}{2}}$

है $\frac{0}{\infty}$

응 ․ㅗ

U

든

흘 공

¿

을 음

$\Sigma$ g

승

응

긍

윤 웡 


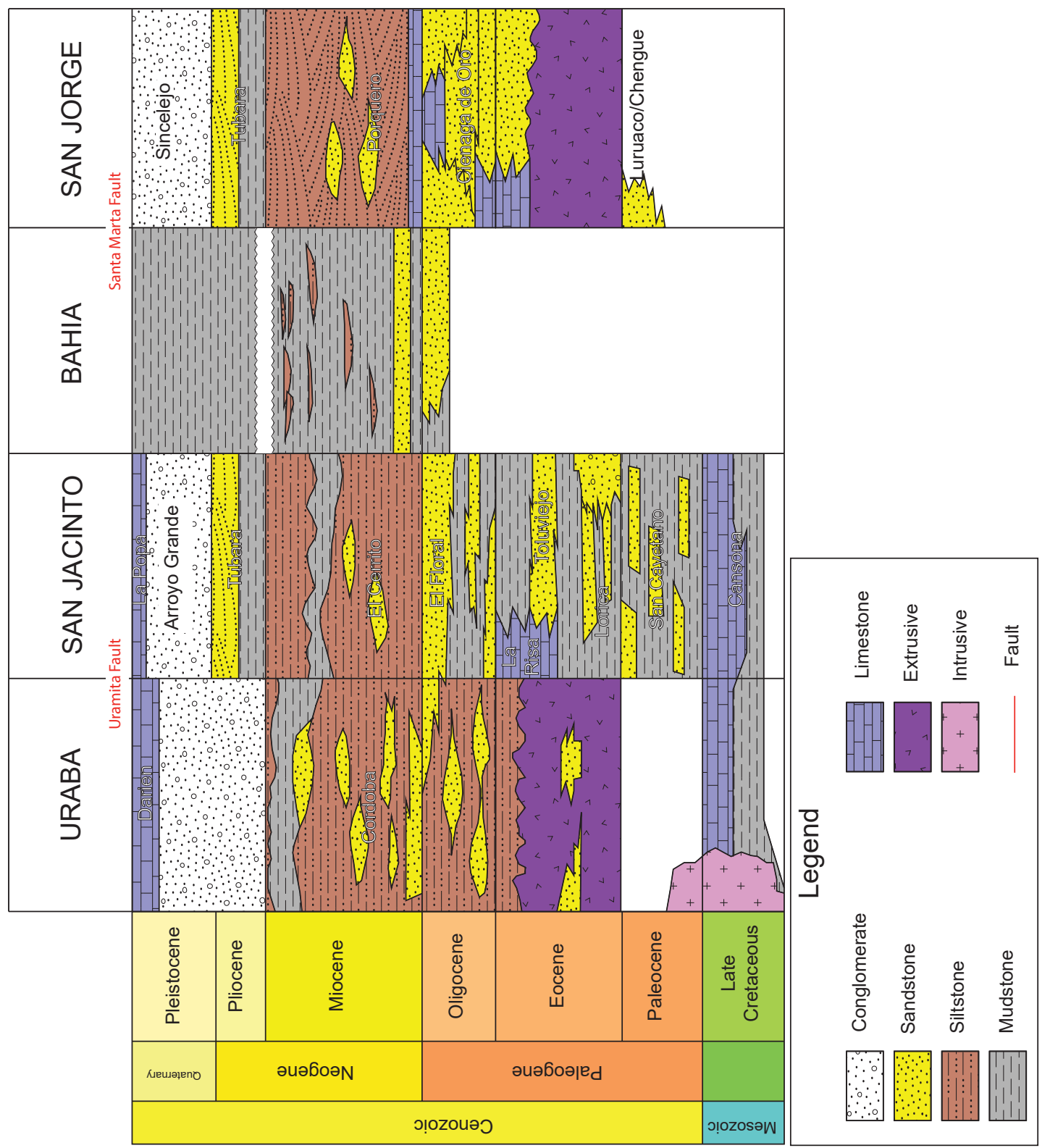

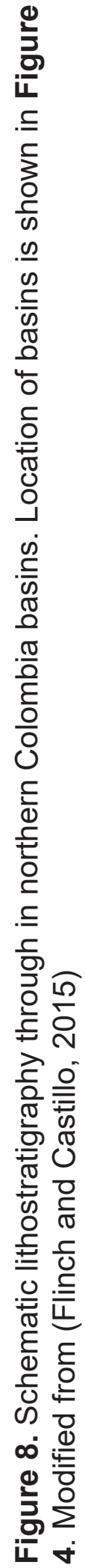


evolution in the northern part of Colombia and Venezuela (Pindell and Kennan, 2001; Escalona and Mann, 2011; Galindo, 2015). The transtension and transpression behind the South Caribbean Deformed Belt, and the Magdalena drainage change northwards associated with The Andean Orogeny during the middle Miocene.

\section{DATASET}

\section{$\underline{\text { Seismic 3D }}$}

The seismic data interpreted for this research is a pre-stack time migration (PSTM) 3D cube covering an area of $1400 \mathrm{~km}^{2}$. The data were acquired for ECOPETROL S.A. in 2003 by Schlumberger's WesternGeco, and was generously provided for this work. It comprises 1196 lines (SW-NE) and 4056 traces (SE-NE) with a bin size of $25 \times 12.5 \mathrm{~m}$, respectively. Seismic depth information achieves until 7 seconds (Two Way Time, TWTT) (approximately $8 \mathrm{~km}$ ) with $4 \mathrm{~ms}$ vertical resolution.

Using CGG's Insight Earth software, data was processed to improve imaging. Using Footprint Removal and Dead Trace Length to remove noise gathered during seismic acquisition. These algorithms improved the seismic imaging and allowed better analyses with regards to defining sequence boundaries on the basin (Figure 9).

The average frequency is $30 \mathrm{~Hz}$ with $20 \mathrm{~m}$ horizontal resolution and $18 \mathrm{~m}$ vertical resolution. Detailed seismic (1 inline: 1 xline) interpretation was completed in IHS's Kingdom Suite software, time slices and horizon slice were generated to highlight a complete description of the stratigraphic and structural evolution of the Bahía Basin. 


\section{Well Data}

The Araza-1 well was drilled during the second semester of 2007 and operated by PETROBRAS Colombia S.A. This well is located inside the Bahía Seismic Volume (Figure 1). The total depth of the well is 13,380 feet with upper Oligocene sediments (TD) is 13,390 feet $(4,081 \mathrm{~m})$ going through Neogene sediments to Late Oligocene. It was abandoned after showing no evidence of oil. Weak presence of gas was found at 3,500 to 4,500 feet and 6,700 to 8,100 feet. No obvious three- or four-way closures are present. The most significant stratigraphic-trap is the truncating Upper Miocene Unconformity (UMU).

\section{INTERPRETATION AND METHODOLOGY}

The study area consists of a series of highly deformed intraslope basins. To ascertain the complex geologic development in the area, the first challenge was to develop the sequence stratigraphic framework. The sequence stratigraphic interpretation was followed by standard methodology of identifying lapouts and erosional truncations, defined by Mitchum et al. (1977). After removing the acquisition footprint, three interpretation episodes were performed in this pull-apart basin. The first step, interpreted every 10 inlines and 10 xlines, identified six main sequence boundaries and faults. Then, a detailed 1-to-1 inline interpretation was performed to adjust each sequence boundary in that basin. Structural, isochronic maps and time slices, delineate main structural and stratigraphic features. To complement the structural interpretation, an edge attribute in the entire volume was run to focus on highlighting fault lineation. Despite the constraint to correlate the Bahía Basin to the well, a relative chronostratigraphic classification - 

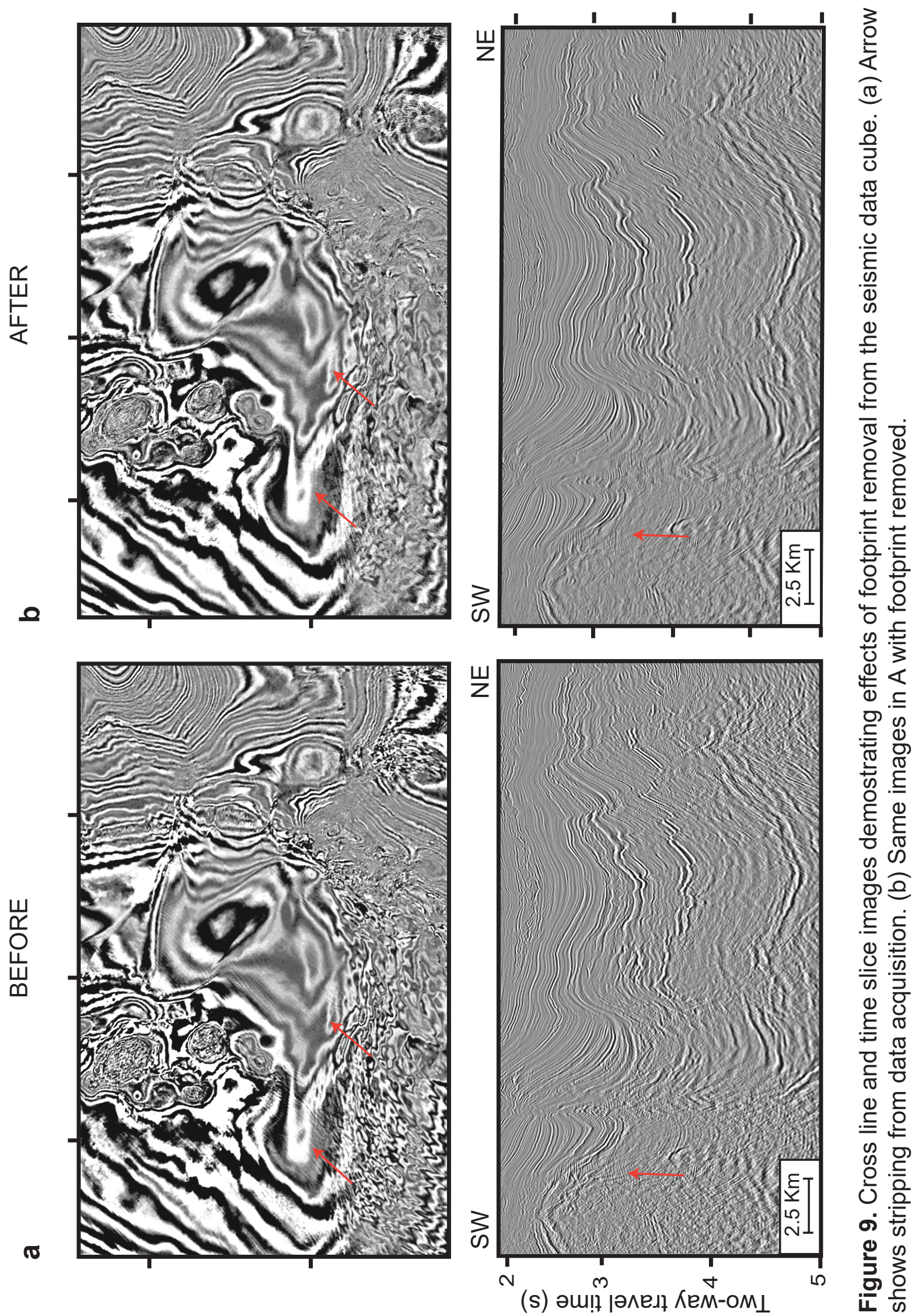


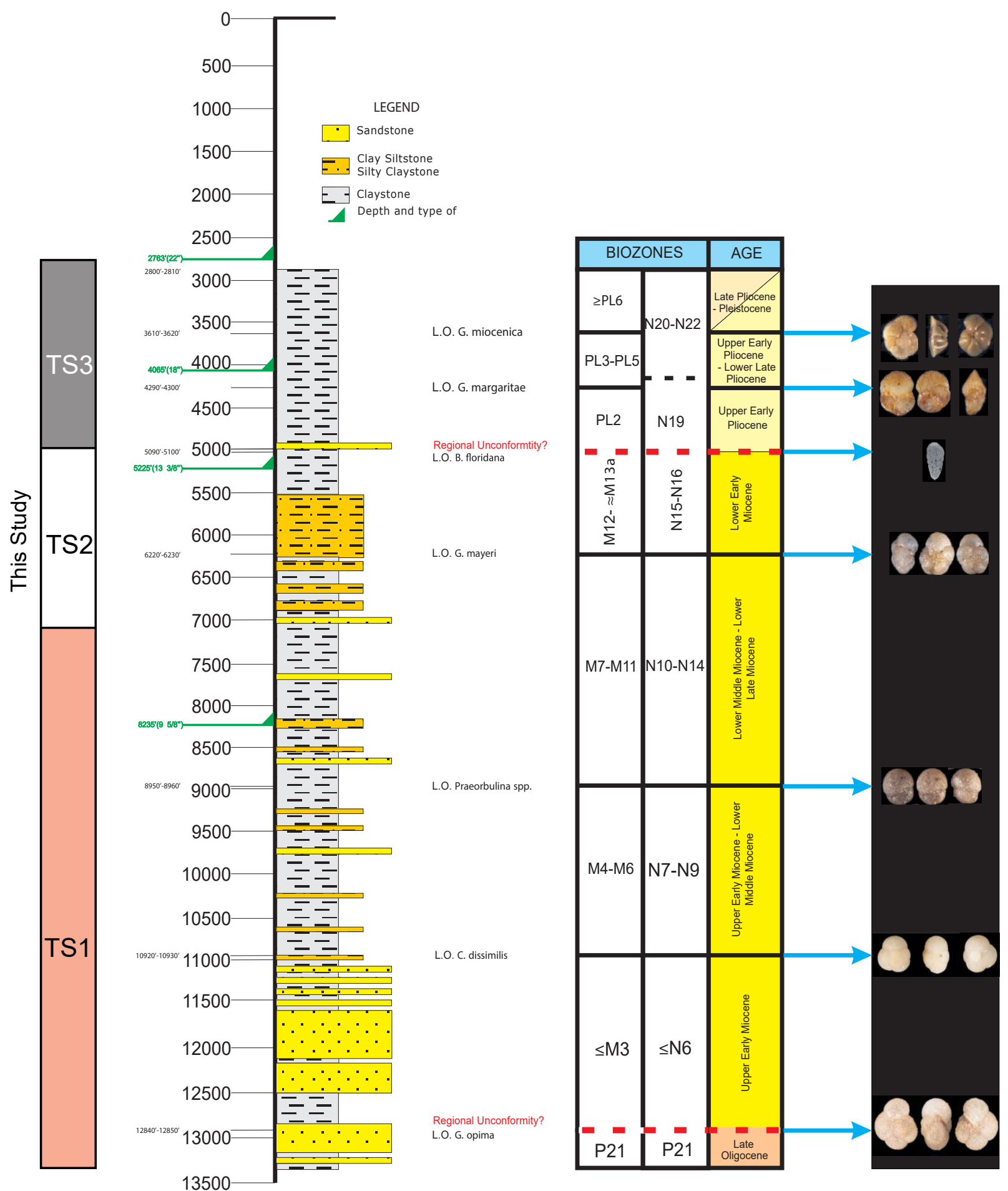

Figure 10. Biostratigraphy of Araza-1 well and foraminiferal biozones. See Figure 1 for location of well. Corresponding tectono-sequence are shown. After Duarte-Forero et. al. (2008) 
using the biostratigraphy described by Duarte-Forero et al. (2008) was made to define the possible age and composition of tectono-sequence 2 (Figure10).

\section{STRUCTURAL SETTING OF BAHIA BASIN}

The Bahía Basin is characterized by strike-slip faults, rotational normal faults, reactivated normal faults, and en echelon structures. All these elements, in addition to the post-stack time processing and shallow gas, make the seismic interpretation challenging. To illustrate the strike-slip structure of the basin, three edge-attribute maps (Figures 11 13), three time-slice maps (Figures 14 - 16), and four regional seismic profiles (Figures 17 - 21) are shown. The edge-attribute maps are from 2.5, 3.1, and 3.5 seconds (TWTT) and illustrate the changing nature of the structure at depth. The edge maps illustrate the structural features at their edges. The time-slice maps illustrate the nature of the dipping strata and structural boundaries.

The Bahia Basin is bounded by two strike-slip faults (Fault A and C) that strike SW - NE and one strike-slip fault that divides the basin into two parts (B Fault) (Figures 11 - 16). This faulting has created four separate sub-basins that trend southwest to northeast. Subbasin 1 (SubB 1) is located to the northeastern part of the area, and bounded by Fault B to the south and Fault A to the north. Sub-basin $2(\operatorname{SubB} 2)$ is bounded by Fault B to the north and separated by sub-basin 3 by the normal major fault. Sub-basin 3 (SubB 3 ) is bounded by Fault B to the north, separated by the Araza High and is the smallest of the three sub-basins. These three sub-basins were likely linked genetically during their Miocene sedimentary fill (Figures 11 - 16). 


\section{Strike-Slip Faults}

The strike-slip faults A-D, are the most prominent structures defining the shape of the Bahía Basin. Fault A is a right-lateral fault with normal movement that extends through the seismic data (Figures 11 - 16). This fault marks the southern edge of the CCM, the Sinu Offshore Accretion wedge, and the Caribbean plate (Galindo, 2015). Imaging along this fault to the north is poor, possibly due to complex structural geometries, shallow gas, and possible of mud diapirs. At depth, the geologic and seismic processing make fault imaging difficult (Figure 17).

Fault $\mathrm{C}$ is a right-lateral fault with normal movement located on the southern part of the Bahía Basin (Figures 11 - 16). The fault strikes northeast and dips steeply to the NW (Figure 20), where it separates the Bahía Basin sediments from older, highly deformed sediments to the south (Figure 20).

Fault $\mathrm{B}$ is a right-lateral fault with normal movement extending through the entire area. This fault separates the Bahía Basin in two different areas (Figures 11 - 16): sub-basins 1 and 2 in the central part and sub-basin 3 and the Araza High in the south. Fault B strikes NW-SE; along the strike, the dip angle of the fault plain changes (Figures 17, 20 - 21). In sub-basins 2 and 3, it dips steeply towards the south (Figure 17). In the shallow portion of the Araza High two fault segments are present (Figure 20). The main fault segments dip northwards.

Fault $D$ is a right-lateral fault with reverse movement located on the northeast part of the Bahía Basin. It strikes at N-S and dips at W (Figure 18). Movement along Fault D movement developed after the Bahía Basin sedimentary fill. 
$\underline{\text { Normal Faults }}$

Normal faults are present in the study area in two locations. A prominent zone of normal faults separates sub-basins 2 and 3 (Figure 18). Three shallow normal faults merge at depth into one master fault, that had previous reverse moment. A narrower prominent zone of normal faults separates the Araza High from sub-basin 3 (Figure 19), where it strikes NW-SE perpendicular to the strike-slip faults (Figures 11 - 16). In sub-basin 2, small offset antithetic and synthetic faults cut the center of the anticline (An-a) center (Figure 18). The faults developed during the Pliocene, after deposition of Tectonosequence 2 (Figure 18). Tectono-sequence 3 was deposited onto the Upper Miocene Unconformity (Figure 18).

Normal Minor Faults

Between faults $A$ and $B$, there is a small area of closely spaced normal faults with small displacement (Figures 11 - 13). These faults vary in strike from $N$ to NE (Figures 11 13). At the Araza High, the faults strike NW; at sub-basin 1, faults strike NE; to the northeast, faults strike E-W. These faults have been interpreted by Galindo and Lonergan (2015) as a result of rotational vertical axis clockwise among the A and B faults during the late Miocene period.

\section{$\underline{\text { Folds }}$}

Tectono-sequence 2 has been characterized by wide synclines and some narrow anticlines (Figures 14 - 16). Sub-basin 1 is characterized by two anticlines that are cut by the normal fault zone on the east, separated by an asymmetric $\mathrm{N}$-trending syncline (Sy-a) (Figure 21), and a west steeply dipping the limb (Figures 15 - 16). 


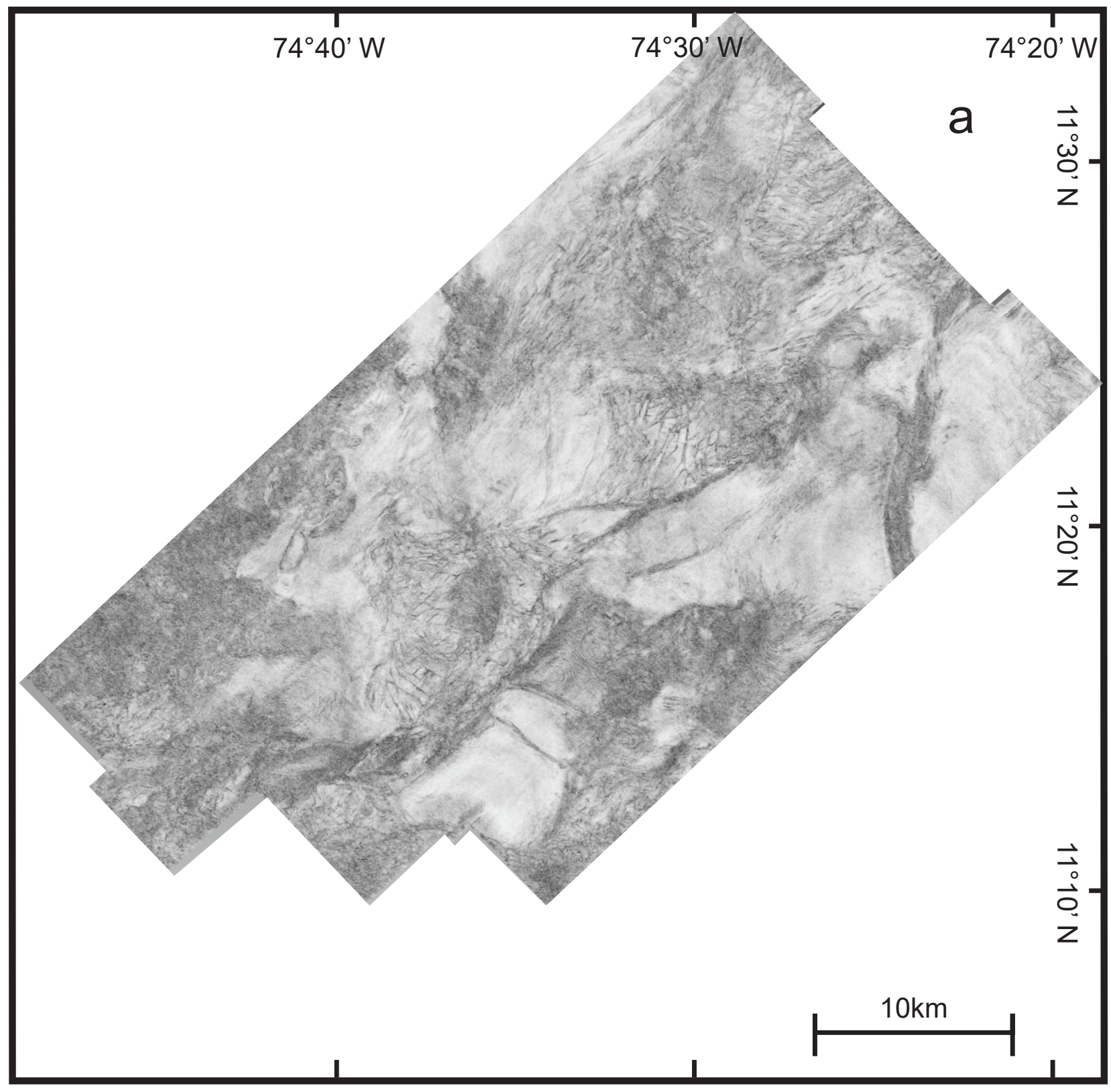

Figure 11. Edge attribute map at 2.5 seconds (TWTT) (a) uninterpreted, (b) interpreted. 


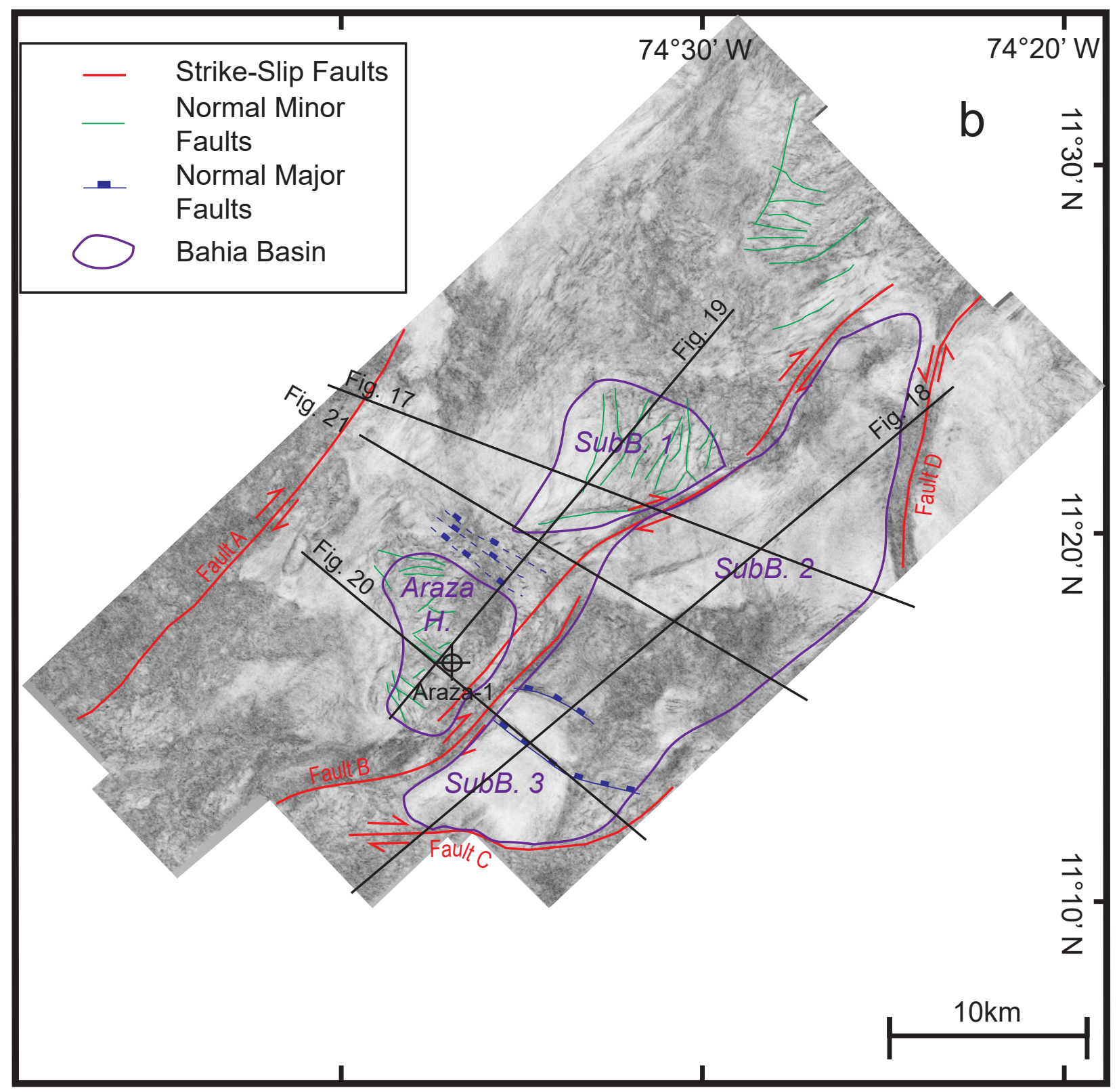

Figure 11. cont. (b) interpreted. Faults, sub-basins and Araza High are shown. The red lines are the strike slip faults and the arrows indicate the displacement direction. Yellow line contour the Bahia Basin. Green faults are the shear faults associated to vertical-axis rotation between $A$ and Bahia. Blue lines are the normal major faults and the squares indicates the movement direction. Location at Figures $17-21$ are shown. 


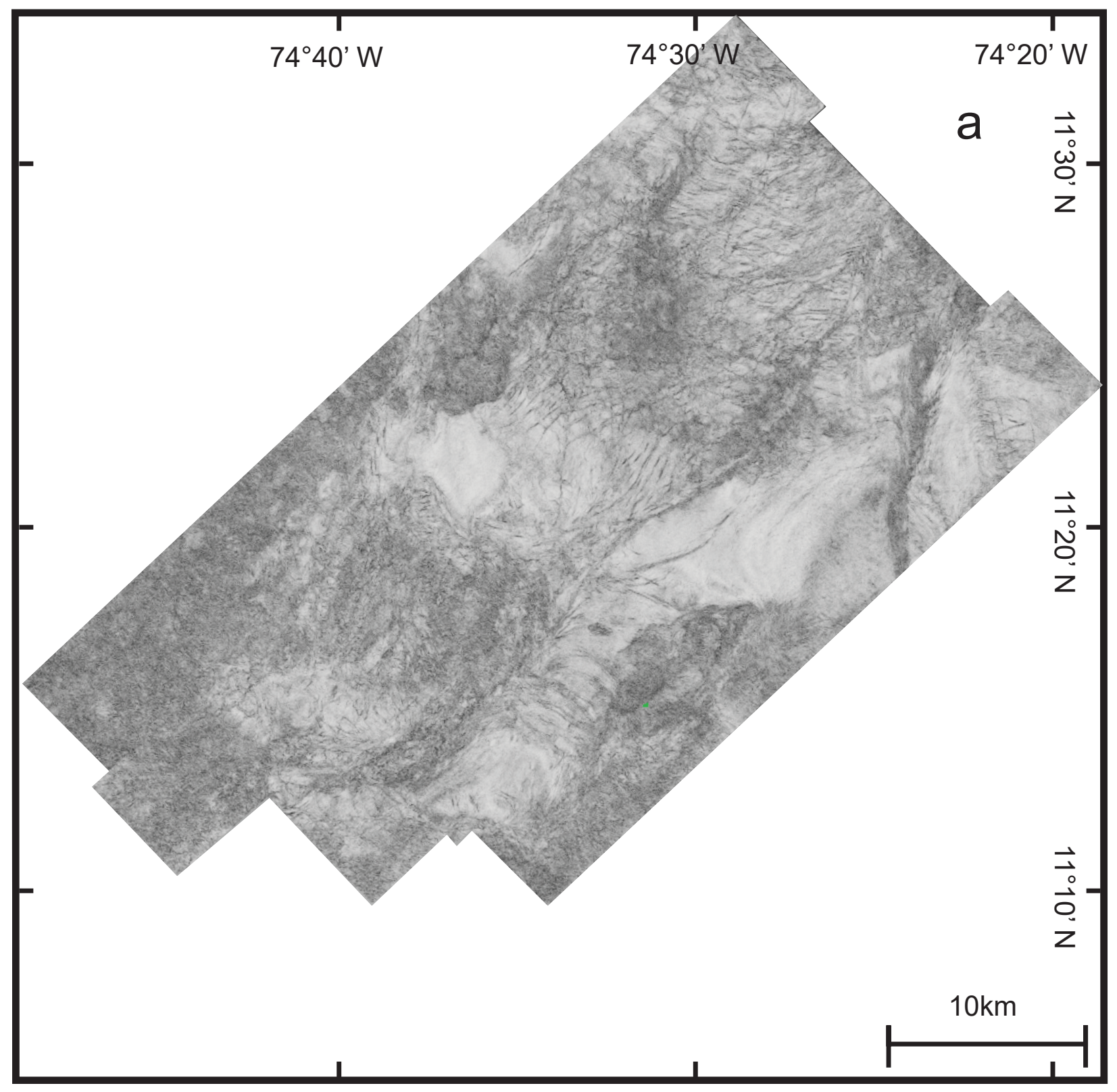

Figure 12. Edge attribute map at 3.1 seconds (TWTT) (a) uninterpreted, (b) interpreted. 


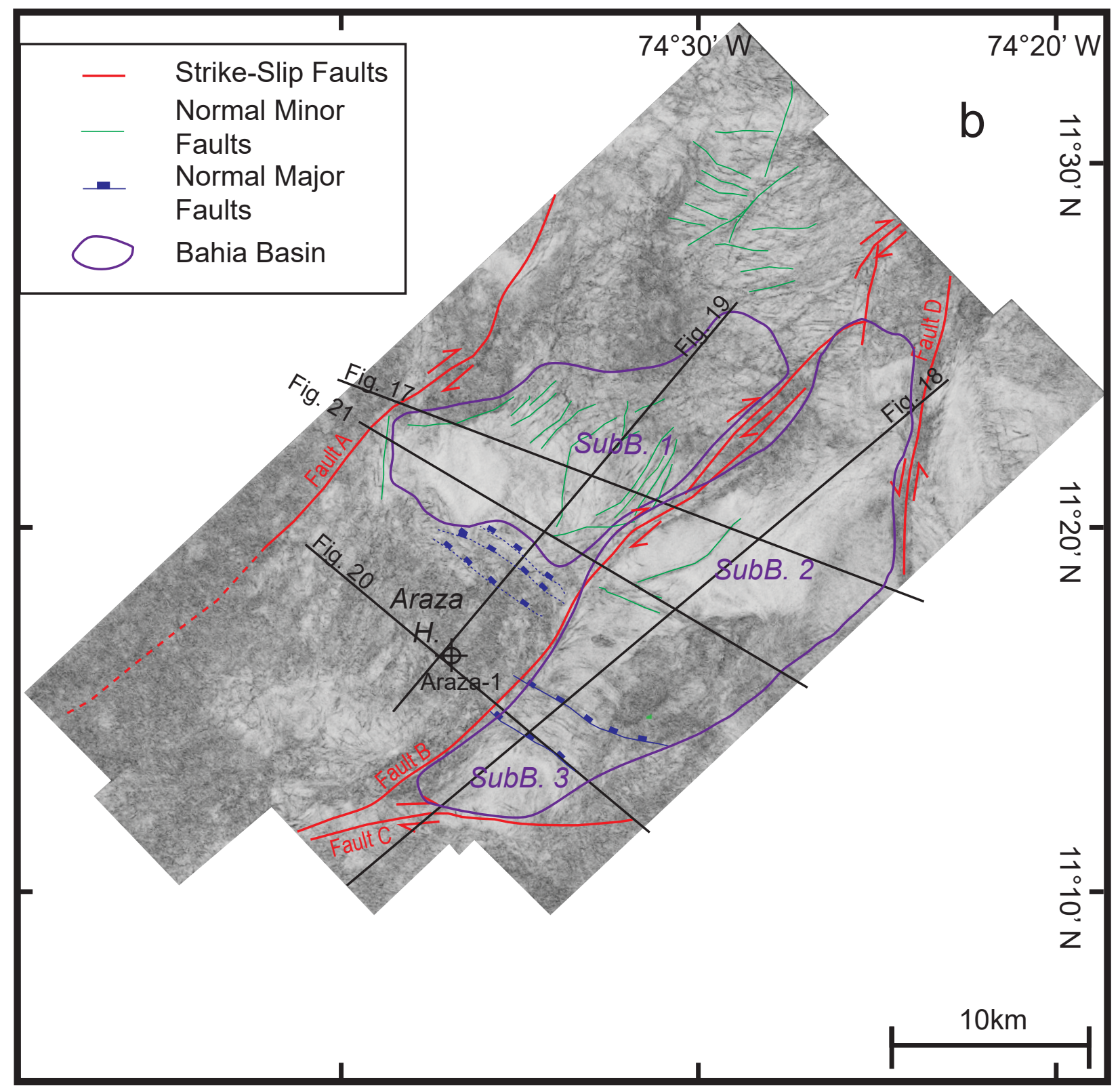

Figure 12. cont. (b) interpreted. Faults, sub-basins and Araza High are shown. The red lines are the strike slip faults and the arrows indicate the displacement direction. Yellow line contour the Bahia Basin. Green faults are the shear faults associated to verticalaxis rotation between $A$ and Bahia. Blue lines are the normal major faults and the squares indicates the movement direction. Location at Figures 17 - 21 are shown. 


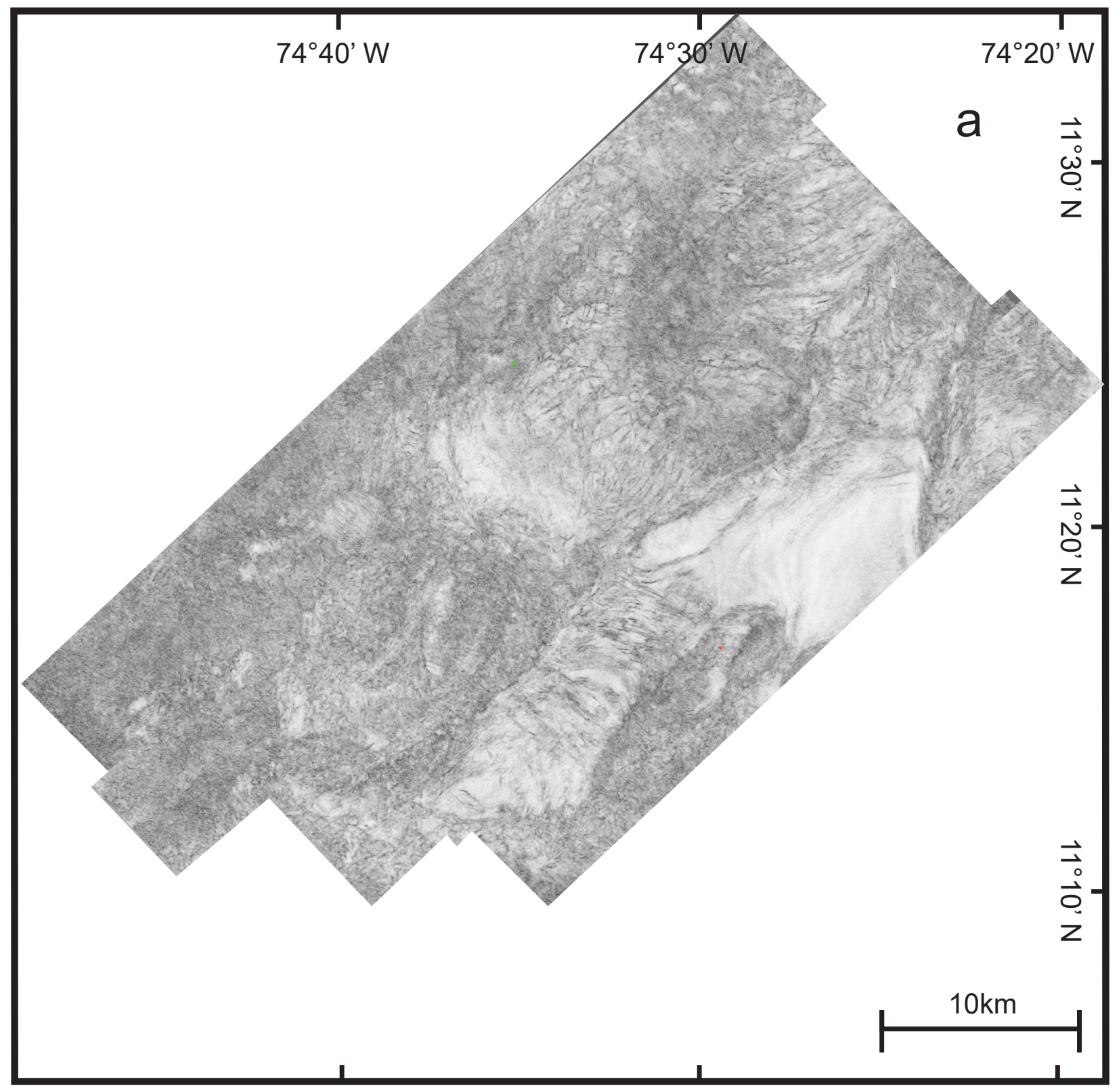

Figure 13. Edge attribute map at 3.5 seconds (TWTT) (a) uninterpreted, (b) interpreted. 


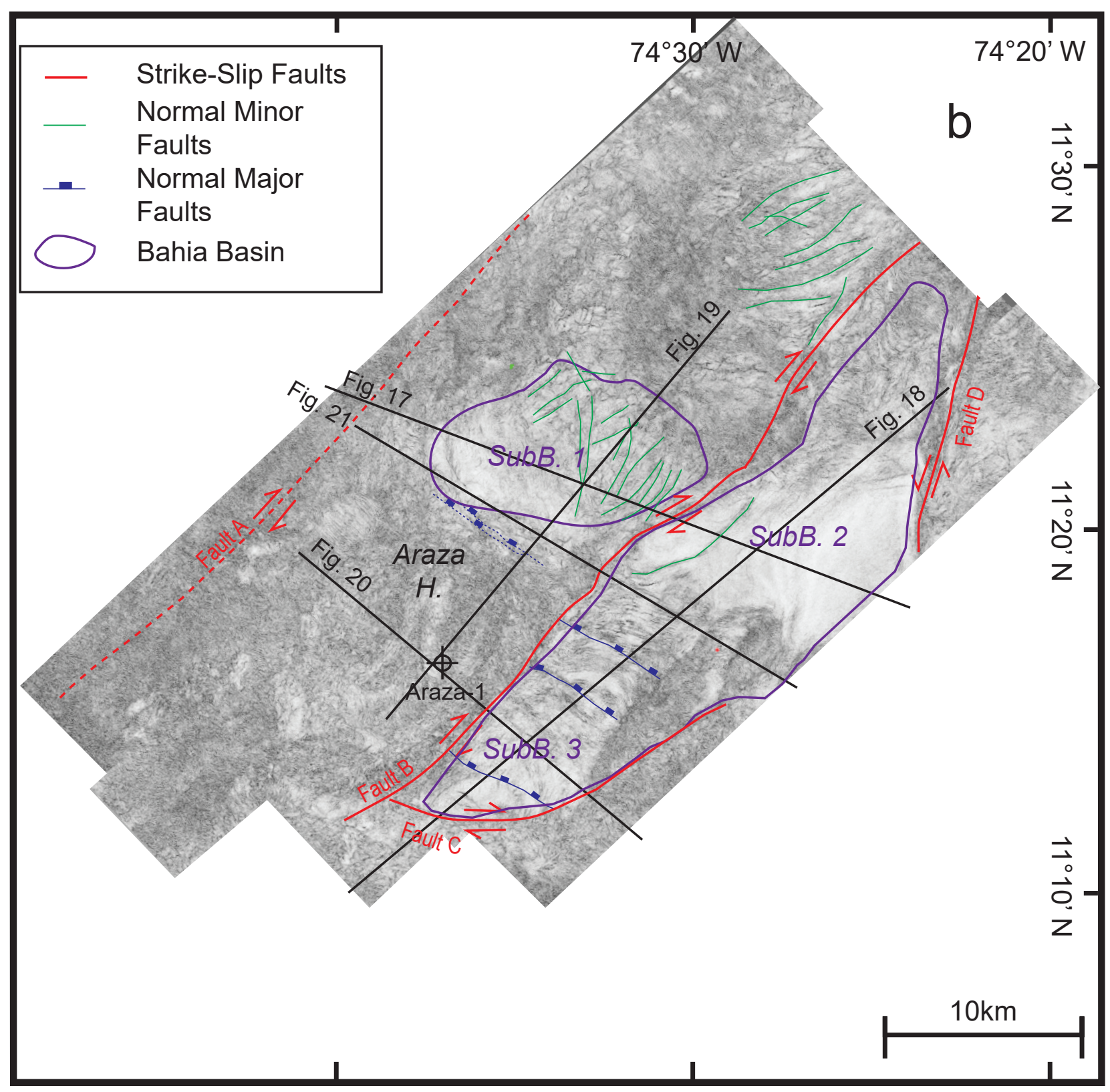

Figure 13. cont. (b) interpreted. Faults, sub-basins and Araza High are shown. The red lines are the strike slip faults and the arrows indicate the displacement direction. Yellow line contour the Bahia Basin. Green faults are the shear faults associated to verticalaxis rotation between $A$ and Bahia. Blue lines are the normal major faults and the squares indicates the movement direction. Location of figures 17 - 21 are shown. 


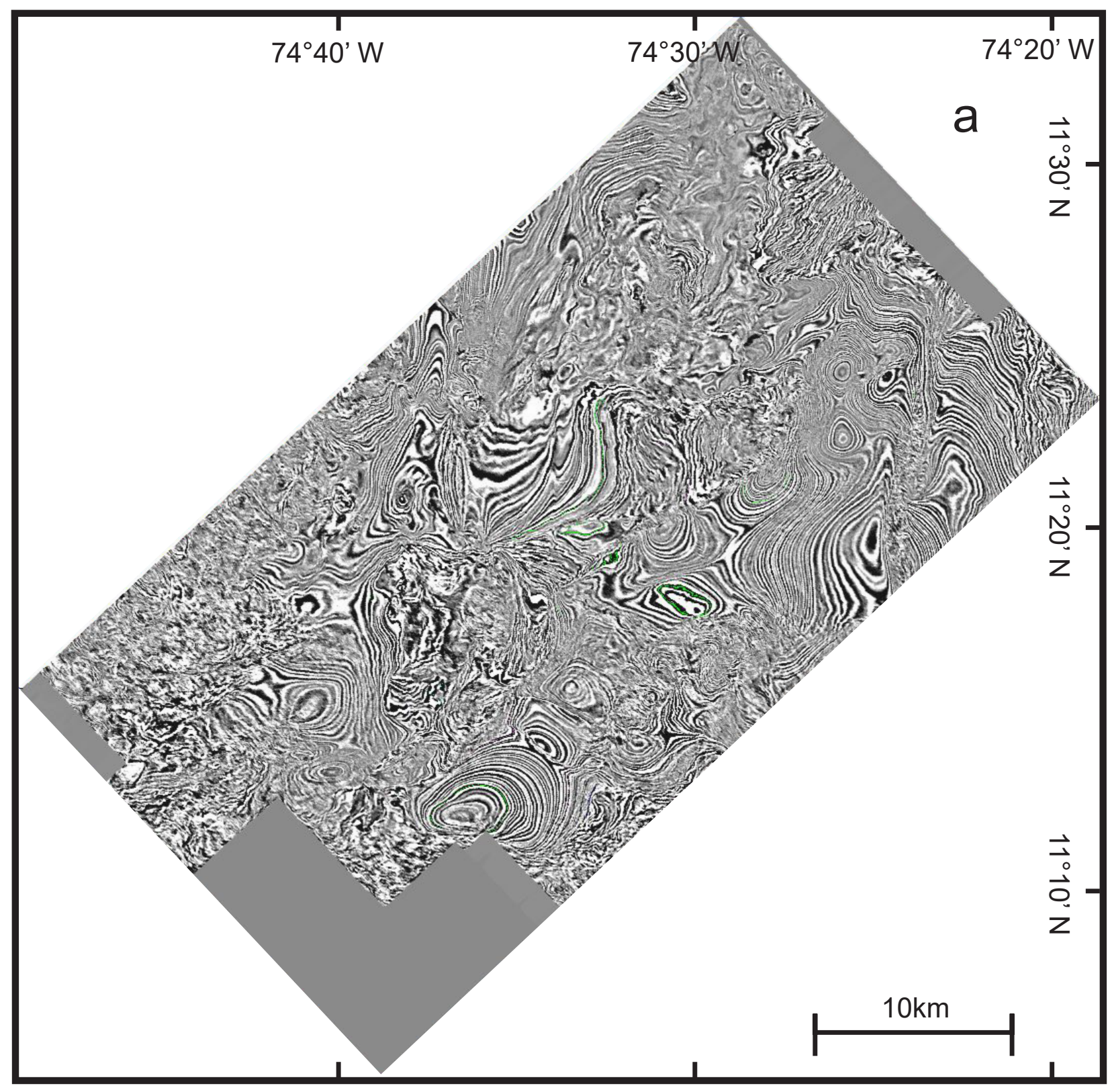

Figure 14. Time slice at 2.5 seconds (TWTT) (a) uninterpreted, (b) interpreted. 


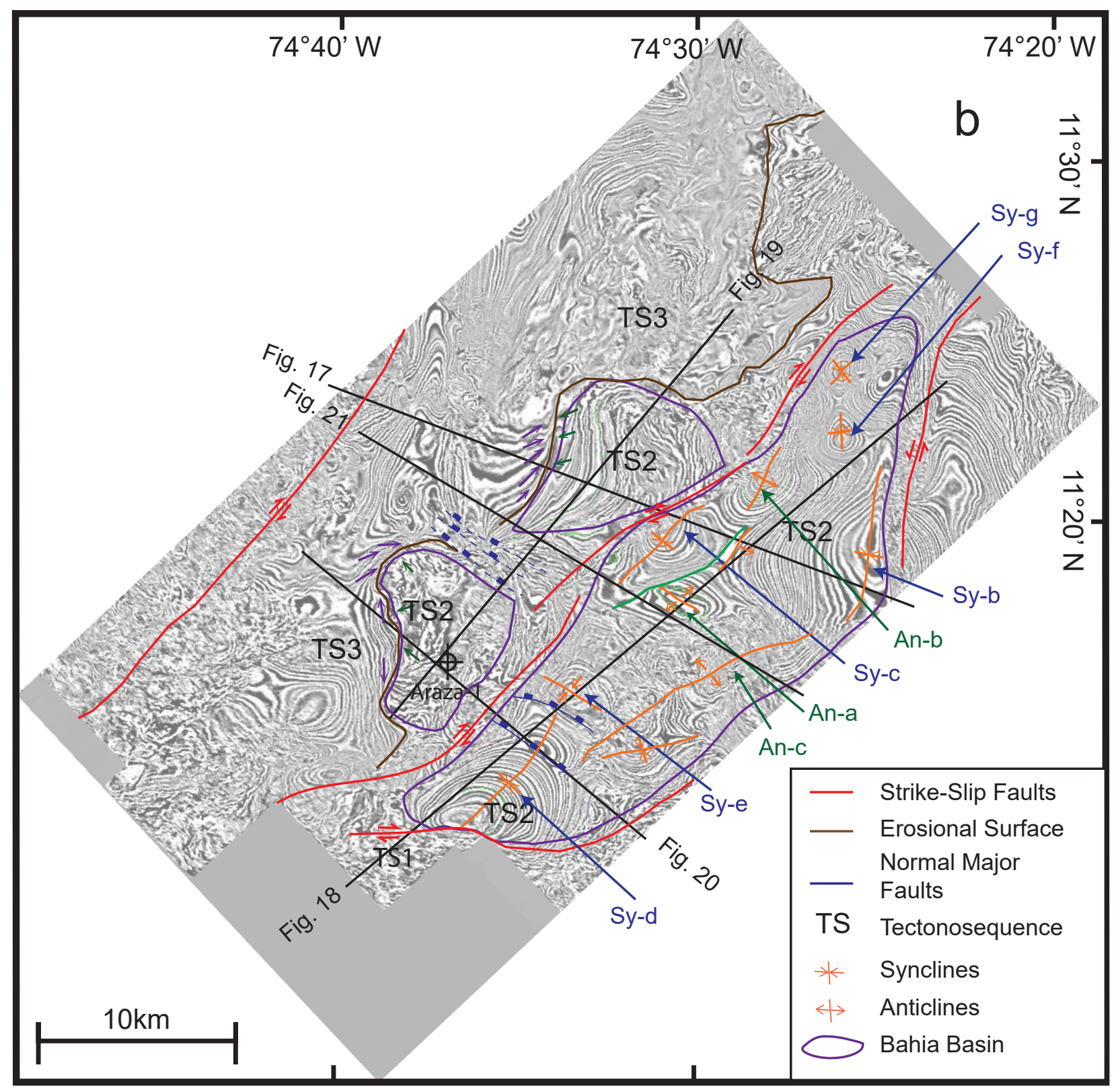

Figure 14. cont. (b) interpreted. Main structures highlighted in orange inside the Bahia Basin. The Miocene Unconformity in Brown separating T2 and T3. Purple arrows indicate onlapping and green arrows the angular truncation. "Sy": Synclines and "An": Anticlines. Location at Figures 17 - 21 are shown. 


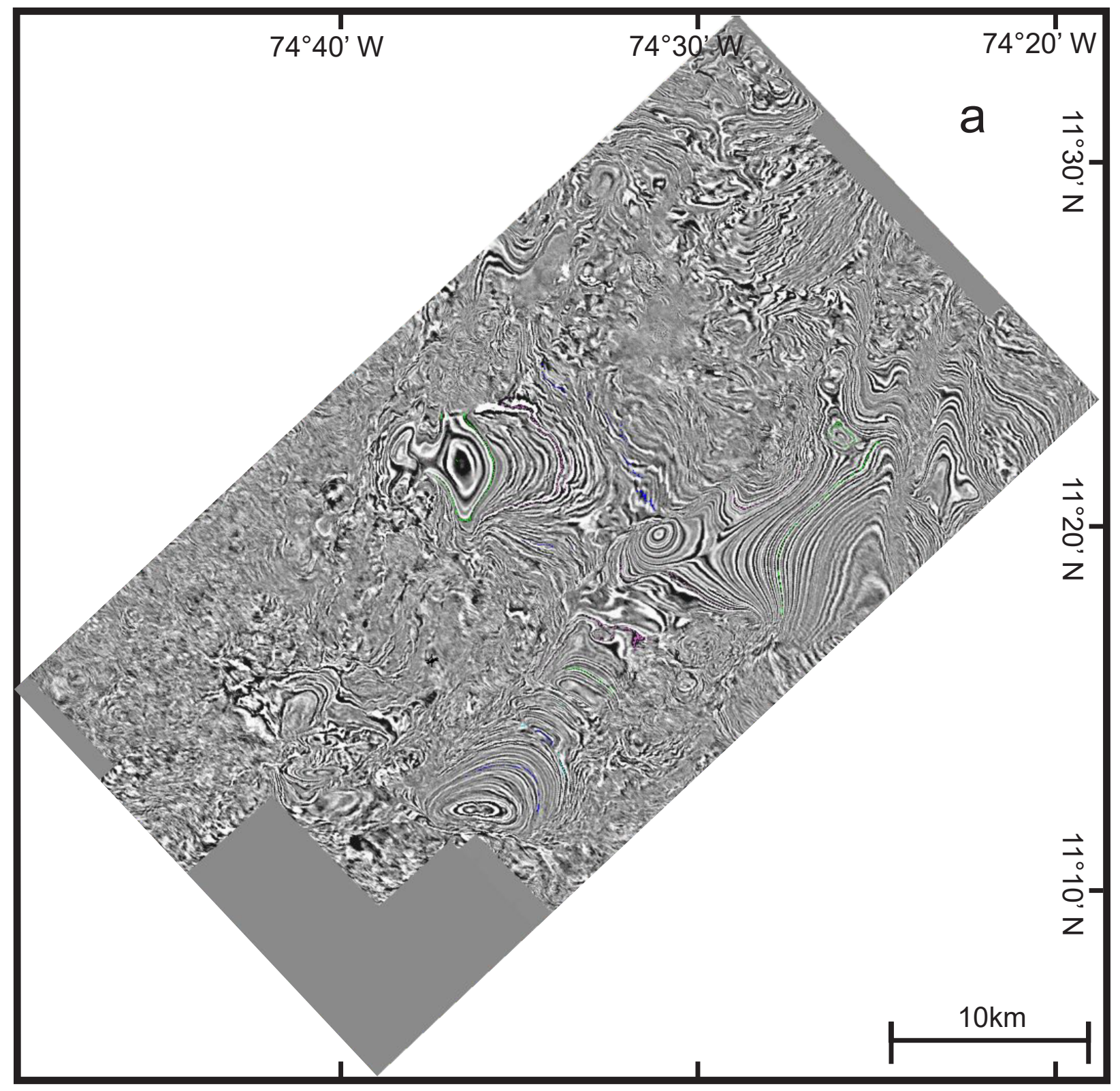

Figure 15. Time slice at 3.1 seconds (TWTT) (a) uninterpreted, (b) interpreted. 


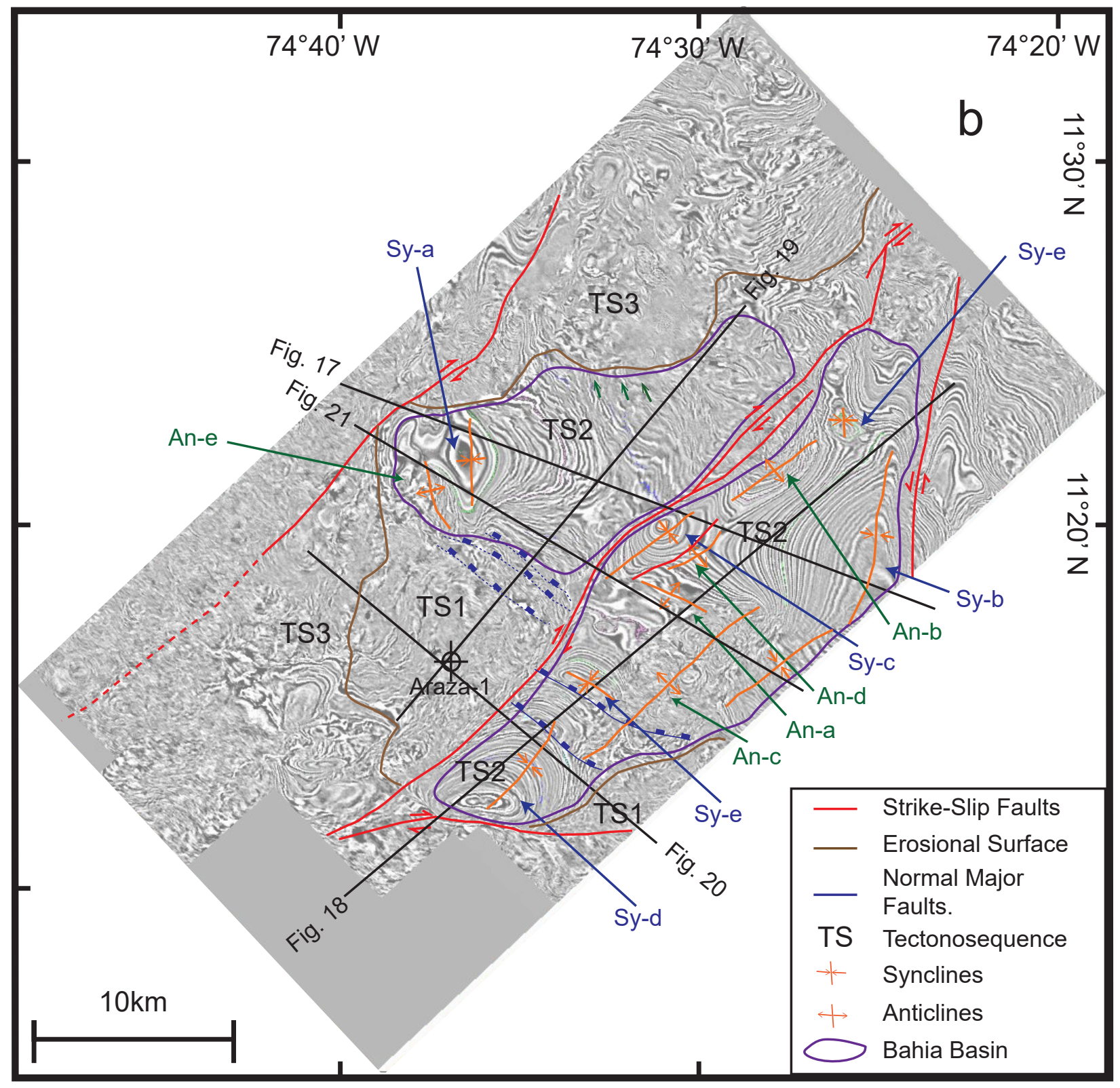

Figure 15. cont. (b) interpreted. Main structures highlighted in orange inside the Bahia Basin. The Miocene Unconformity in brown separating TS2 and TS1 for TS3. Notice the erosive process after the late Miocene. Green arrows the angular truncation. "Sy": Synclines and "An": Anticlines. Location of Figures 17 - 20 are shown. 


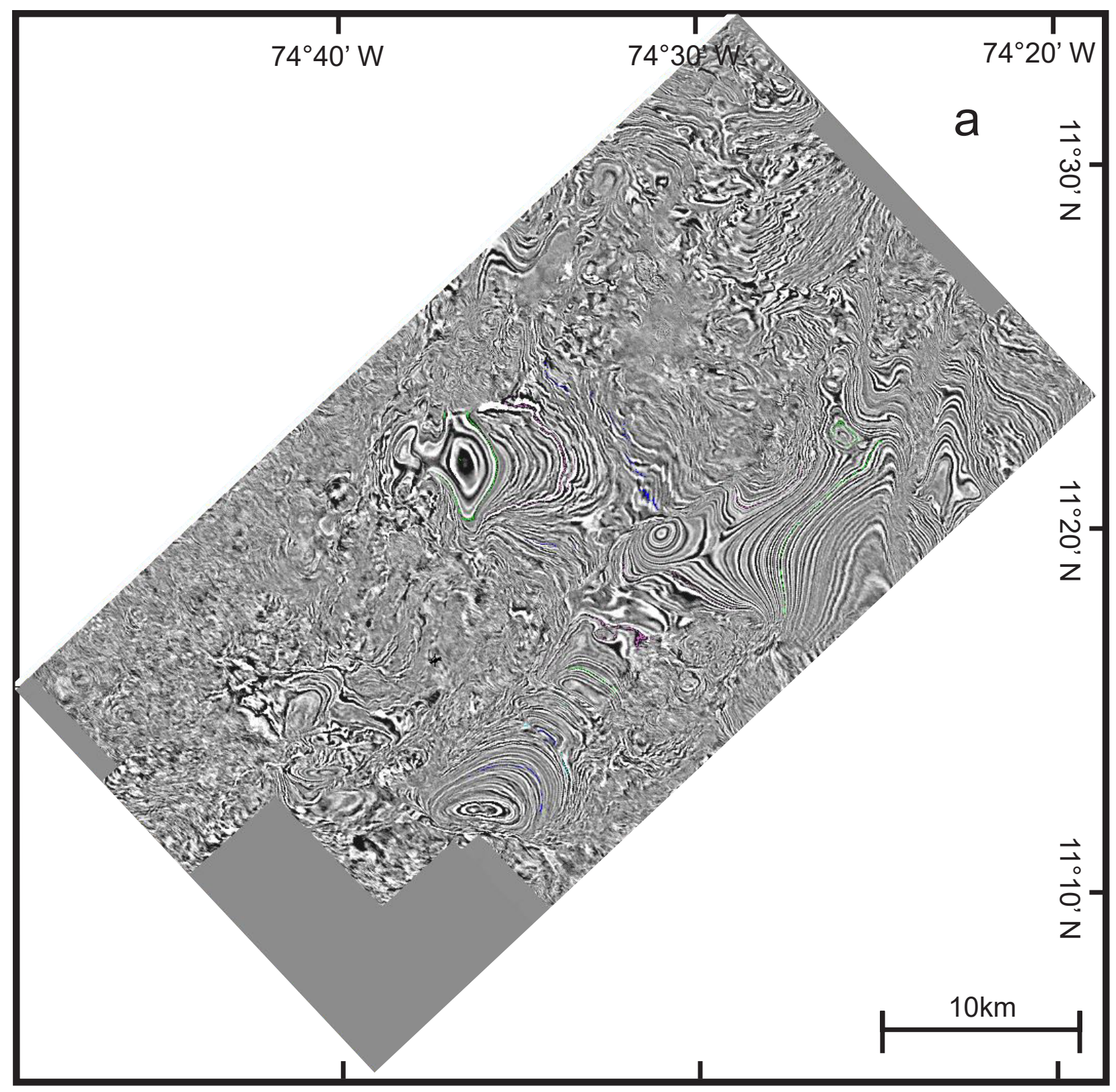

Figure 16. Time slice at 3.5 seconds (TWTT) (a) uninterpreted, (b) interpreted. 


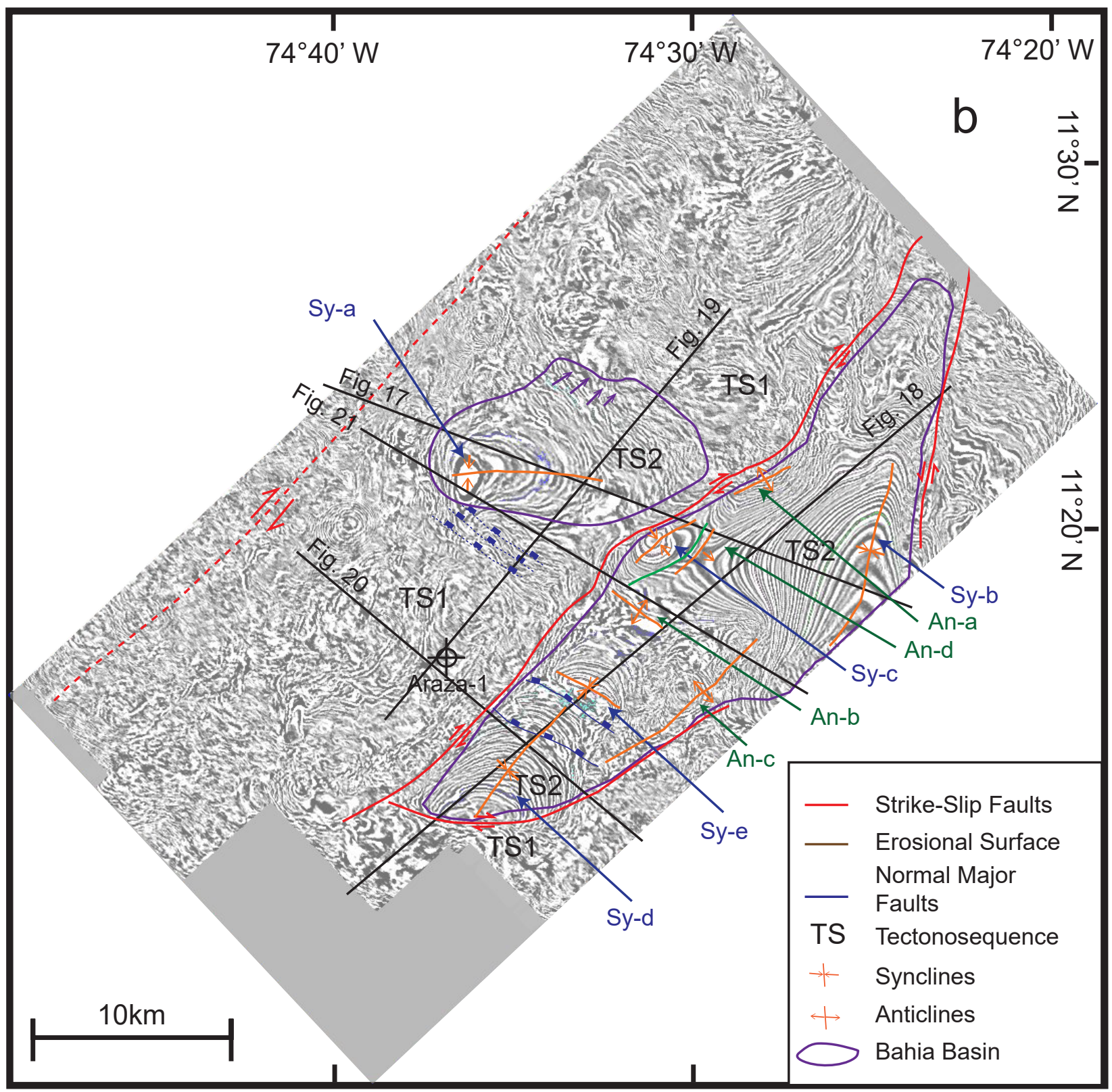

Figure 16. cont. (b) interpreted. Main structures highlighted in orange inside the Bahia Basin. Purple arrows indicate onlapping between TS2 and TS1. "Sy": Synclines and "An": Anticlines. Location at Figures 17 - 21 are shown. 
Sub-basin 2 consist of a series folds associated with Fault B. Three anticlines are present; a prominent NNE trending syncline $(S y-c)$ is present to the east. The fold has a steep limb to the east, cut by Fault $D$, and a gently dipping western. The crest of the western limb is cut by a fault (Figure 17), and the beds dip to the west culminating in a shallower syncline (Sy-c). An ENE trending anticline (An-d) is present immediately adjacent to the east of Fault B (Figure 17). Northwards to Sy-c, a NE trending anticline (An-b) structure is cut by Fault B. A third, smaller syncline (Sy-e), is present parallel cut by a normal fault. It shallows to the east in a wide WNW anticline (An-a) with An-c and Sy-b (Figures 14 16). To the south, narrow anticline (An-c) trends to the northeast (Figure 21) reaching the western part of sub-basin 3 .

Sub-basin 3 shows a prominent NE-trending syncline located to the south with a slight offset at the central part of the structure by a normal fault (Figures 14 - 16).

\section{TECTONOSTRATIGAPHY}

Three main tectono-stratigraphic sequences (TS1-TS3) were identified that correspond with the major Cenozoic structural events. Then, six sequences, likely third-order, were defined inside TS2 (Figures 22 - 25). These tectono-sequence are the primary sedimentary fill in the Bahía Basin. Each is summarized here.

\section{Tectono-sequence 1 (TS1) (? pre-early Miocene period)}

TS1 has variable depth across the area. It is structurally shallow in the north, south, and west (Araza High). It is at 3 seconds (TWTT) along the Araza High (Figure 20), 2 seconds (TWTT) on the south part of sub-basin 1 (Figure 18), and deepens to 5 seconds (TWTT) on the Bahía Basin. The seismic resolution for TS1 is poor, characterized by low 
frequencies, low amplitudes, and low continuity. The TS1 is correlated by Galindo (2015) to the wedge accretionary prism expands the San Jacinto Belt prism (Figures 6, 8). The top of TS1 is not younger than the middle Miocene, as indicated by the biostratigraphy in the Araza-1 well (Figures 19, 20). Seismic interpretation of TS1 is inhibited by the poststack time migration processing. Prominent seismic migration smiles are present, obscuring the geology (Figure 20). In some areas with better seismic resolution, clear folding and thrust faults can be imaged (Figures 17 - 20). Erosional truncation at the top of TS1 marks the transition from contractional deformation to more transtensional (TS2) deformation in the evolution of the area (Figures $17-21$ ). In some areas of TS1 can be subdivided into more units; however, the poor seismic resolution does not allow for regional correlation of additional units.

\section{Tectono-sequence 2 (TS2) (early middle Miocene - upper Miocene)}

TS2 is characterized by higher frequencies, low continuity, and higher amplitude in the Bahía Basin, in contrast to the underlying TS1 low frequencies, continuity and amplitudes. Now the Araza High, TS1 has the development of the three sub-basins occurred in TS2 was associated with a transtensional phase. Clear stratal onlap and thinning onto TS1 is present in some areas (Figures 18, $23-\mathrm{NE}$ ). The top of TS2 is strongly erosional in some areas (Figures 19, 20, 24, 25 - Araza H. SW; and to NW of sub-basin 1). Six depositional sequence, likely third order, are recognize (S1 - S6). Variable thicknesses are present among and within the six sequences. In one area along the Fault B (Figure 23), clear contractional growth on folding sub-basin 2 continues from sequence 1 through sequence 5 . 

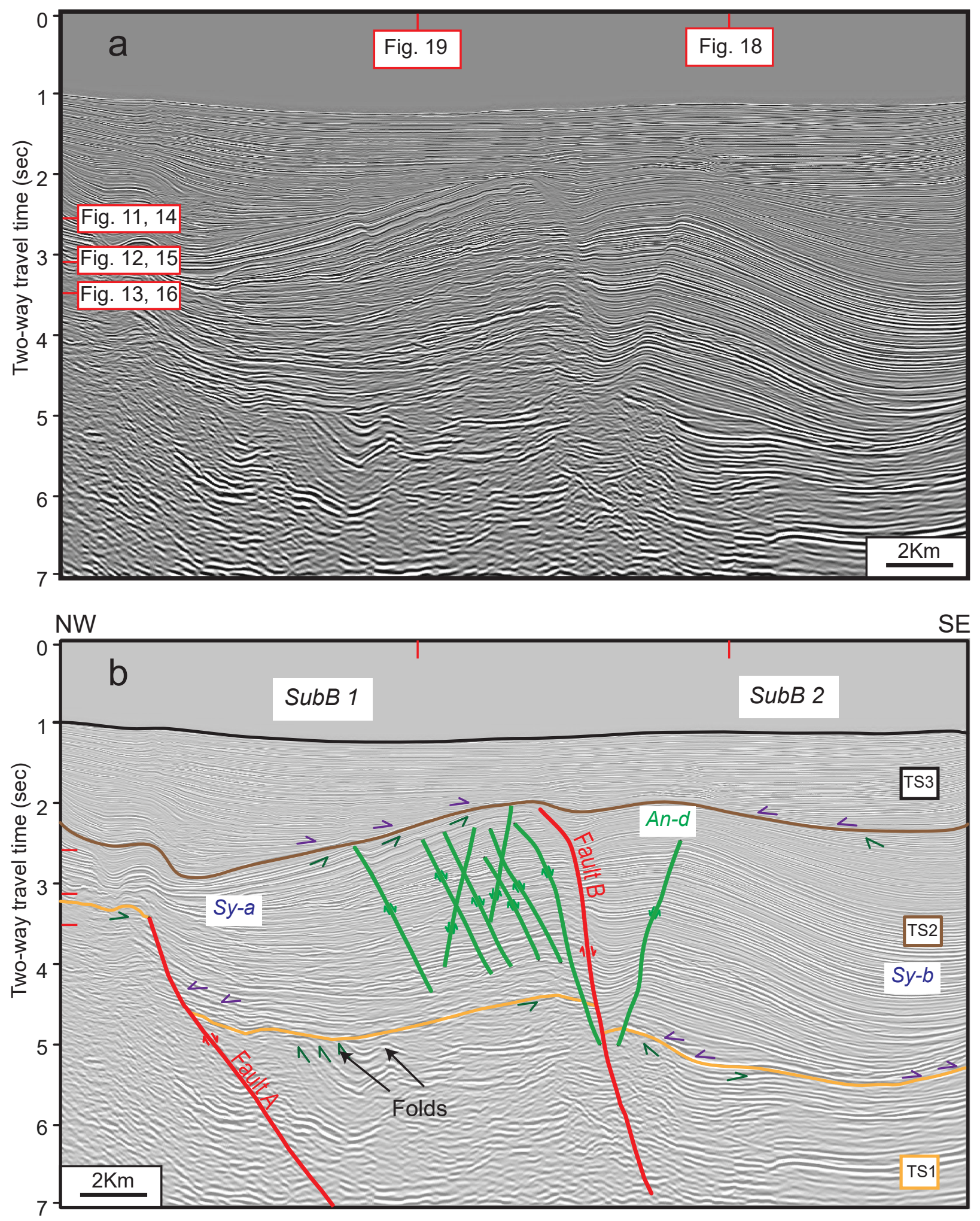

Figure 17. Seismic profile across sub-basins 1 and 2, Bahia Basin: (a). uninterpreted, (b). interpreted. Purple arrows indicate onlap and green arrows show erosional truncation. Synclines (Sy-a, Sy-b) and faults are shown. See Figures 11 - 16 for location at profile. 


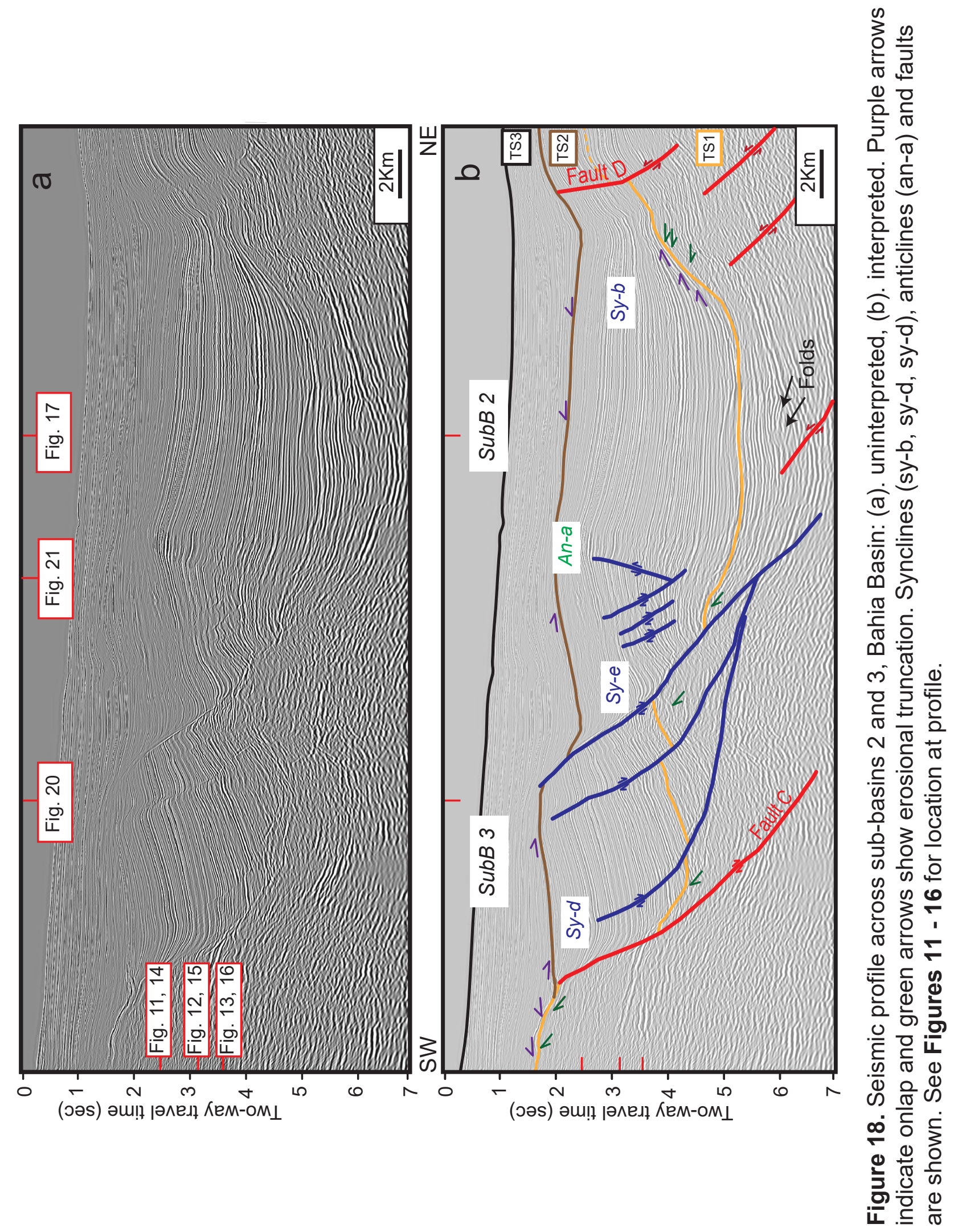



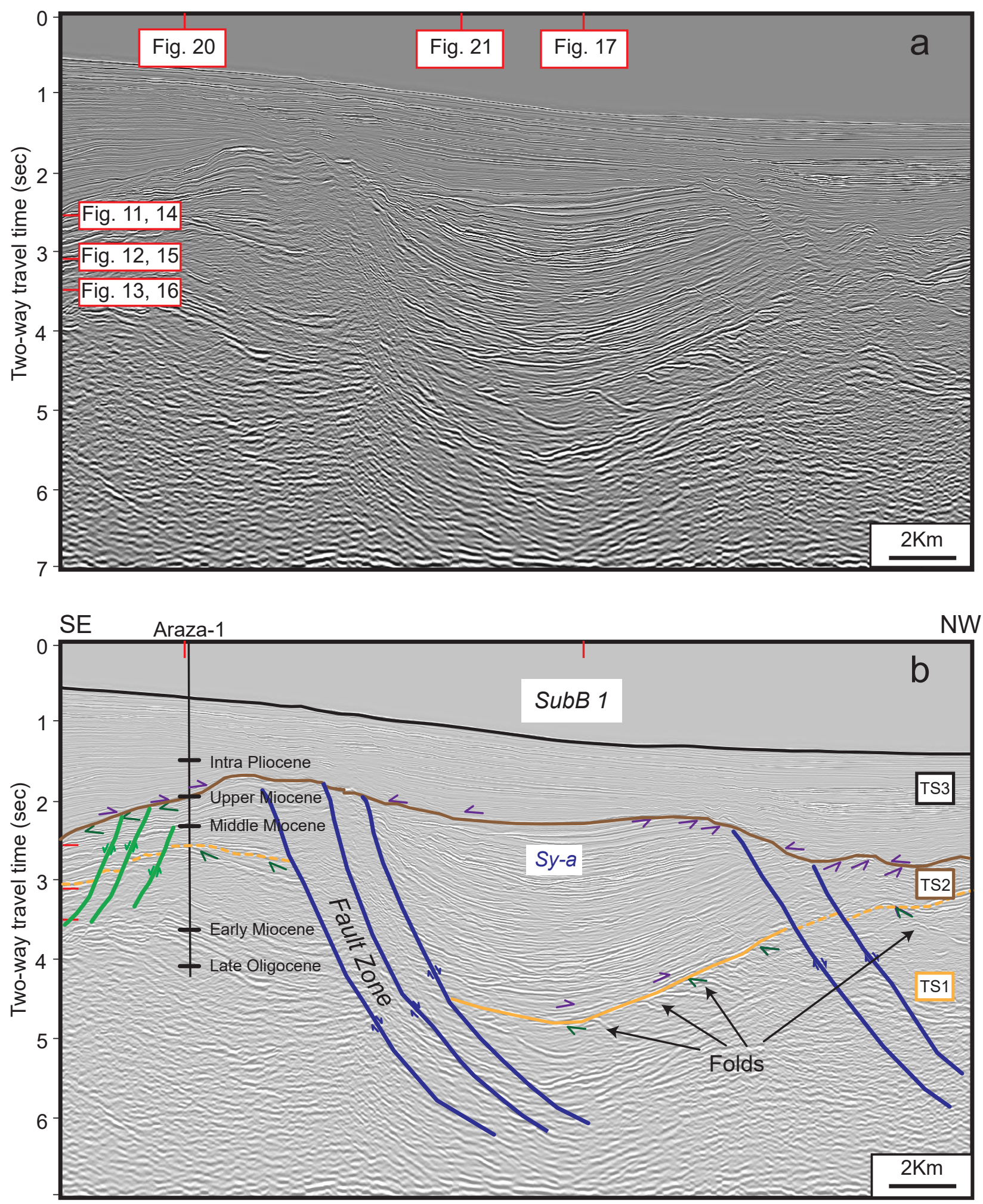

Figure 19. Seismic profile across sub-basins 1 and Araza High, Bahia Basin: (a). uninterpreted, (b). interpreted. Purple arrows indicate onlap and green arrows show erosional truncation. Synclines (Sy-a) and faults are shown. Araza-1 shows picks interpreted by Duarte-Forero et al. (2008). See Figures 11 - 16 for location at profile. 

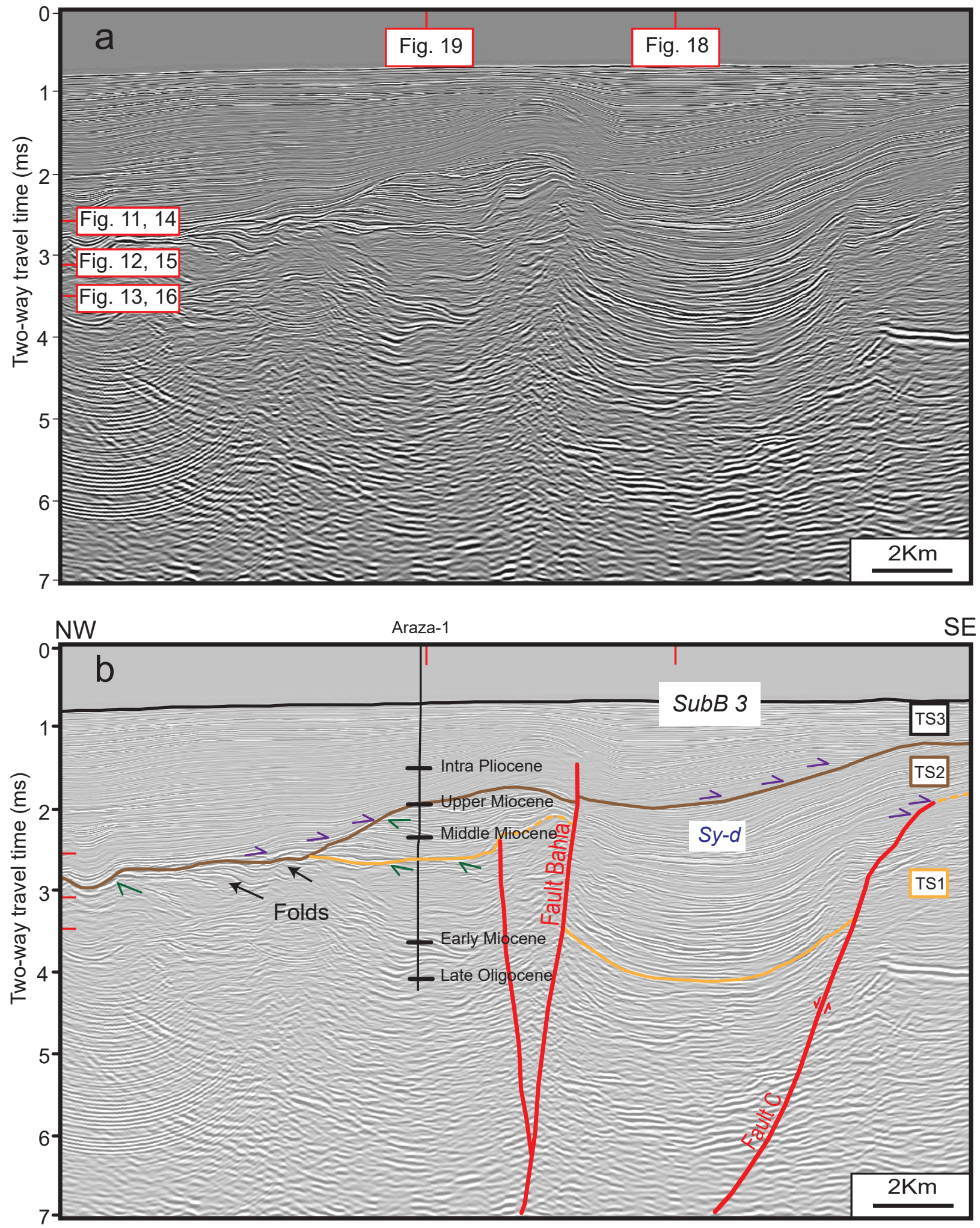

Figure 20. Seismic profile across sub-basins 3 and Araza High, Bahia Basin: (a). uninterpreted, (b). interpreted. Purple arrows indicate onlap and green arrows show erosional truncation. Synclines (Sy-d) and faults are shown. Araza-1 shows picks interpreted by Duarte-Forero et al. (2008). See Figures 11 - 16 for location at profile. 

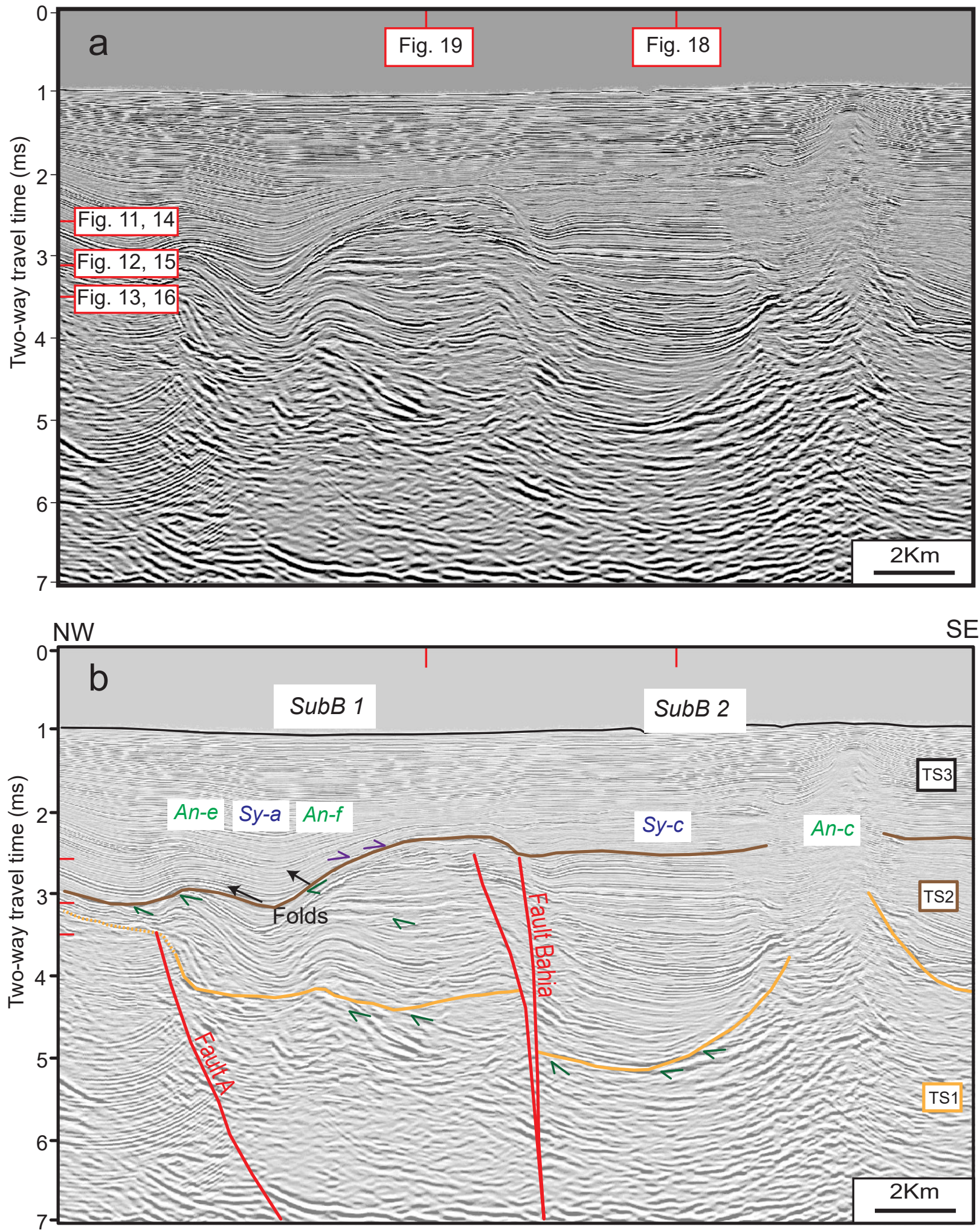

Figure 21. Seismic profile across sub-basins 1 and 2, Bahia Basin: (a). uninterpreted, (b). interpreted. Purple arrows indicate onlap and green arrows show erosional truncation. Synclines (Sy-a, Sy-c), anticlines (An-c, An-e, An-f) and faults are shown. Anticline (An-C) is poor imagining by gas chimeney. See Figures 11 - 16 for location at profile. 


\section{Tectono-sequence 3 (TS3) (Pliocene - Recent periods)}

Significant uplift of the end of TS2 is present in some areas, creating significant variation in the area. The northern side of Fault B in sub-basin 1 was inverted; as indicate (Figure 22) significant regional onlap of strata from the north and south. The TS3 becomes a passive fill, following a period of structural deformation; TS3 infilled the bathymetry created by deformation at the top of TS2. Prominent onlap surfaces defines TS3 at its base across the area. The reflections are parallel to divergent/convergent, with high amplitude and good continuity. The TS3 is associated to high-input sediments reported in CCM, associated with the Andean Cordillera maximum uplifting (Flinch, 2003).

\section{SEISMIC STRATIGRAHIC ANALYSES}

Six main sequences were defined in tectono-stratigraphy 2 (TS2), the main area of interest in this research. The structural complexity hinders correlation between basin challenging, given the lack of biostratigraphy data. Jump correlation is necessary based on facies similarity that defines the stratigraphic position. In addition, each of the subbasins underwent progressive deformation in the stratigraphic interval of interest, making each sub-basin different in its structure and stratigraphy. To define these sequences, it was necessary to describe the surface relationship by using flattened seismic profiles across each sub-basin on top of their sequence boundary. Thus, using structural maps, isochron maps, and horizon slices, the structural variation was defined at depth, thickness lateral changes, and basin-fill trend. 

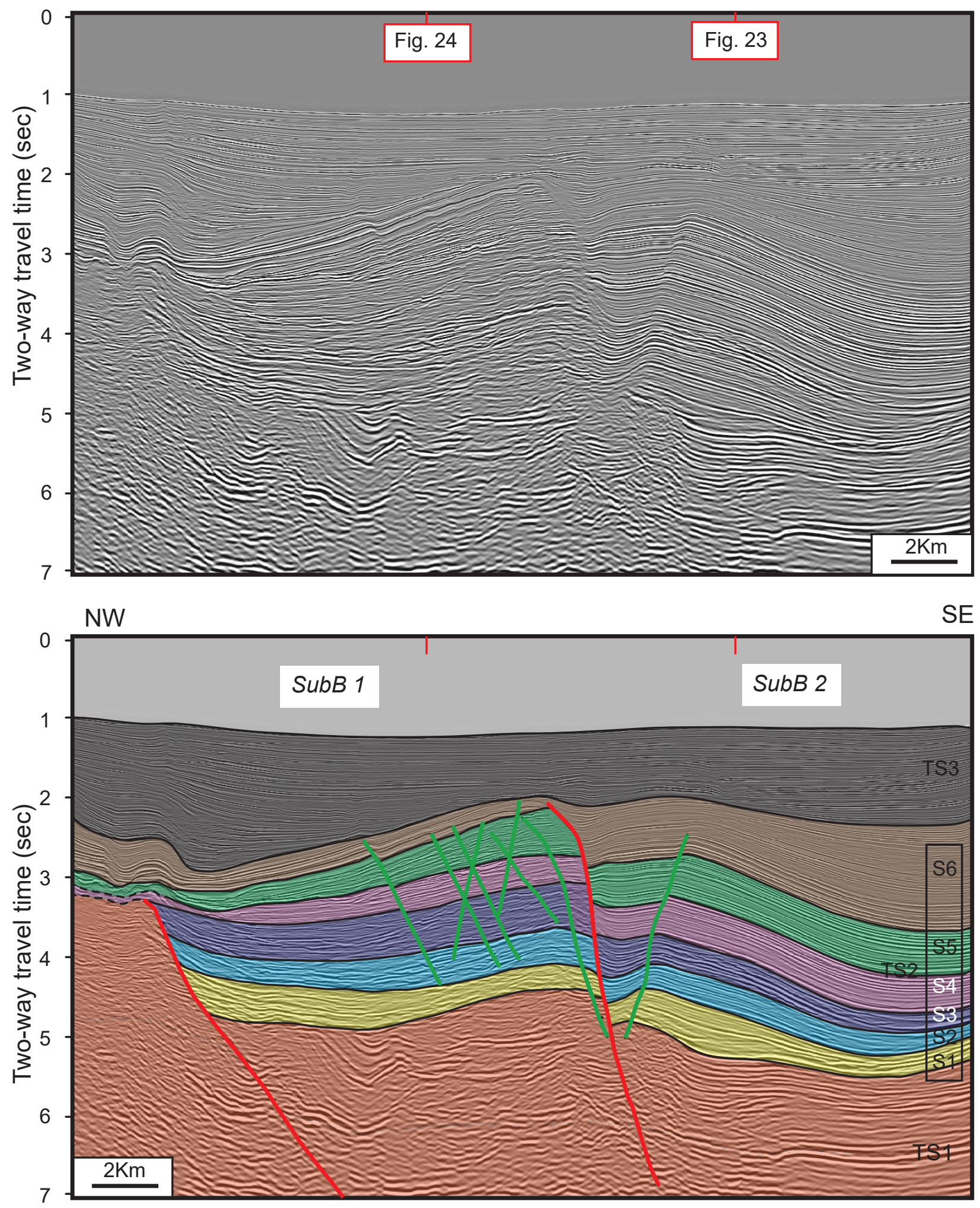

Figure 22. Seismic profile showing the sequence distribution of TS2 in Bahia Basin (Color Units). (a) uninterpreted (b) interpreted. The red lines are the strike-slip faults and the green lines the normal minor faults. See Figure 17 for annotations. 

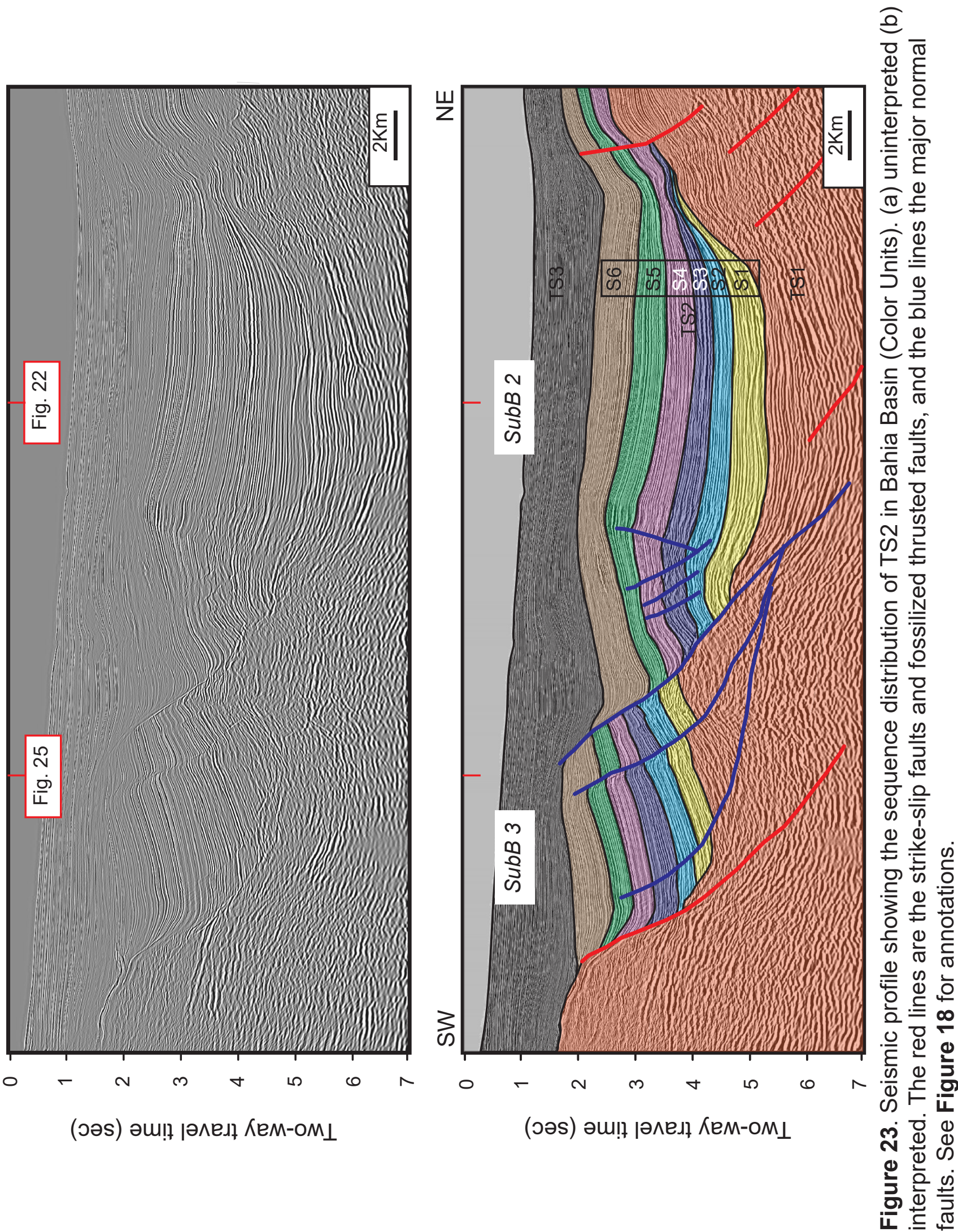

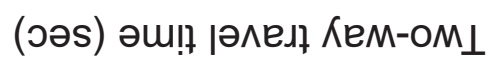

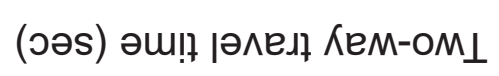



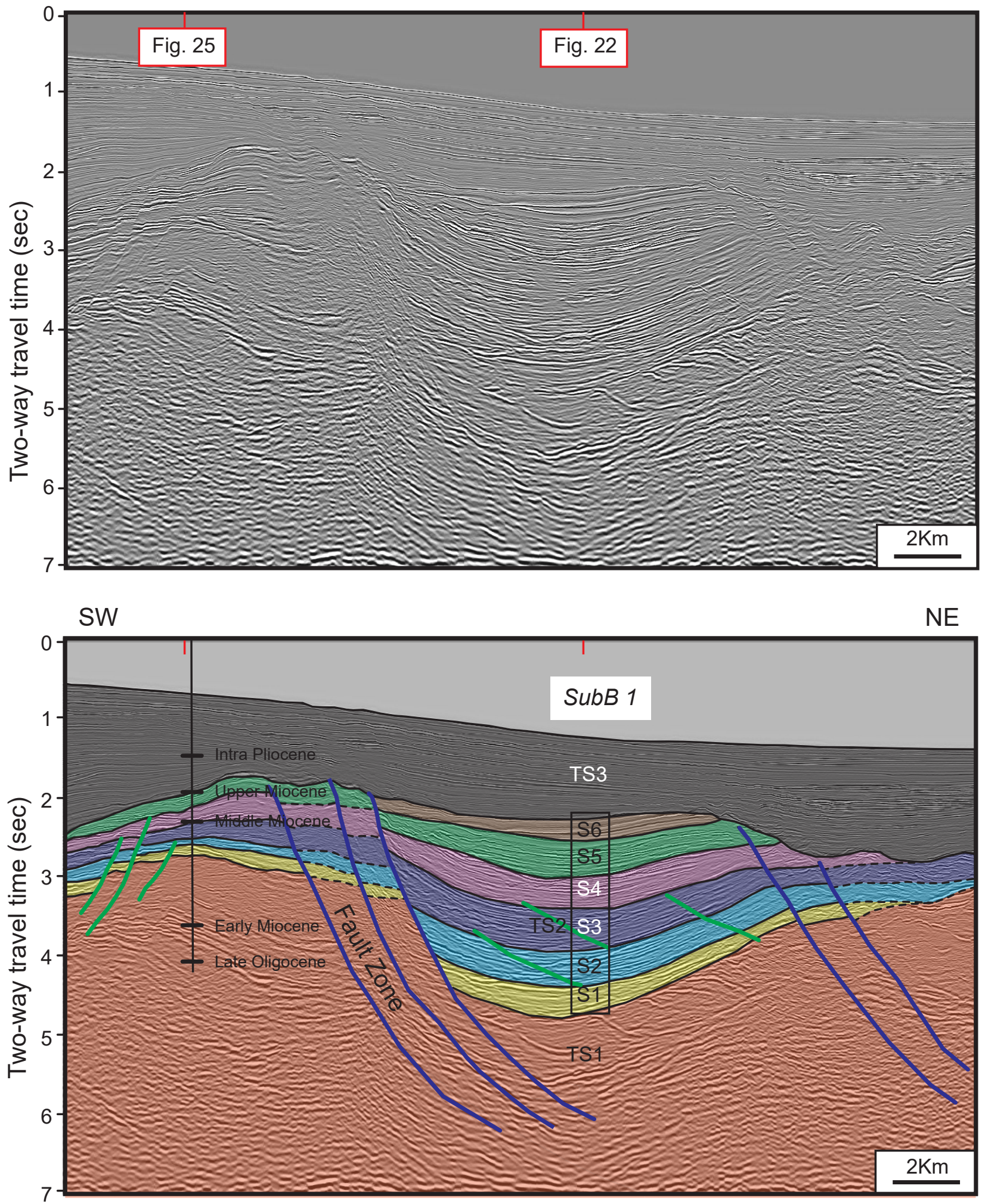

Figure 24. Seismic profile showing the sequence distribution of TS2 in Bahia Basin (Color Units). (a) uninterpreted (b) interpreted. The blue lines are the major normal faults and green lines are the minor normal faults. See Figure 19 for annotations. 

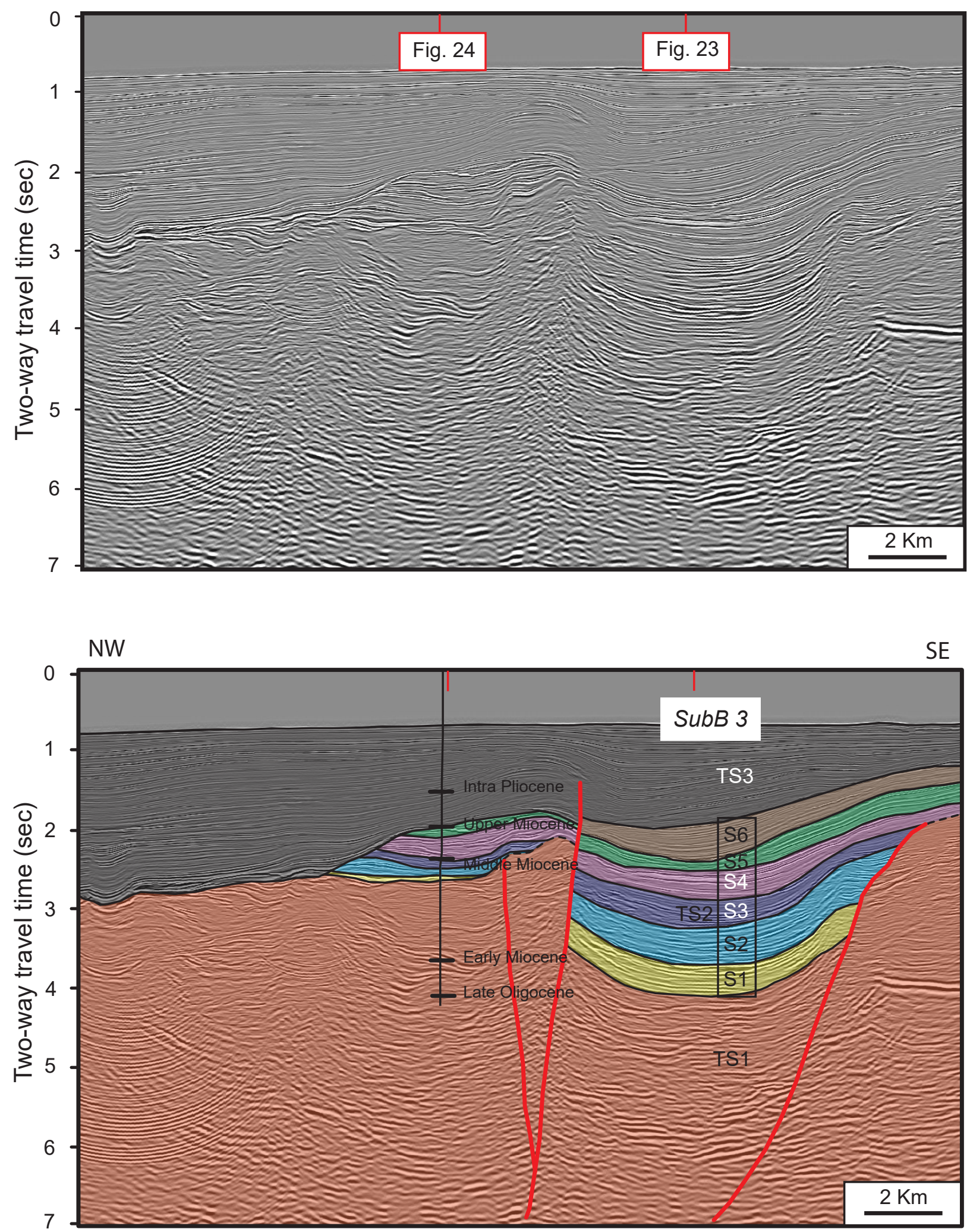

Figure 25. Seismic profile showing the sequence distribution of TS2 in Bahia Basin (Color Units). (a) uninterpreted (b) interpreted. The red lines are the strike-slip faults. See figure 20 for annotations. 


\section{Sequence 1}

\section{$\underline{\text { Key Surfaces }}$}

At the base on sequence 1 (SB1), the sequence boundary is defined by underlying angular truncation, more prominent in sub-basins 1 and 3 (Figures 26, 28), and less prominent in sub-basin 2 (Figure 27)

Stratal onlap onto the lower sequence boundary 1 (SB1) is present at the eastern part of sub-basin1, the southern part of sub-basin 2 and the eastern part of sub-basin 3 (Figures 26 - 28). Concordant reflections are present in the central part of each sub-basins, in their depocenters (Figures 26 - 29). The reflections are concordant below the upper boundary (SB2) in all three sub-basins (Figures 26 - 29).

\section{$\underline{\text { Time-Structure Map }}$}

The lower sequence boundary (SB1) ranges from 1.7 to 5.5 seconds (TWTT) (Figure 30).

In sub-basin 1, SB1 varies from 3.5 to 4.7 seconds (TWTT) (Figure 30). The lowest point is located in the western central part of the sub-basin, adjacent to the major frontal normal fault and the Araza High (Figure 24). A syncline (Sy-a) trends $\mathrm{N} 70^{\circ} \mathrm{W}$. The basin shallows to the east-northern and west-southern, reaching 3.5 and $4.1 \mathrm{~s}$, respectively (Figures 24, 30).

In sub-basin 2, SB1 ranges from 3.5 to 5.6 seconds (TWTT) (Figure 30). Two synclines are present (Synclines B and C), separated by a shoulder. Syncline B (Sy-b) is located to the south-west, reaches the deepest point at $5.5 \mathrm{~s}$, and trends $\mathrm{N} 10^{\circ} \mathrm{W}$ (Figures 23, 30). Syncline $\mathrm{C}(\mathrm{Sy}-\mathrm{C})$ is a smaller structure that trends $\mathrm{N} 80^{\circ} \mathrm{E}$ and is cut by Fault B (Figures 
22, 30). The SB1 shallows moderately to the south in a narrow anticline (An-c) to $3.8 \mathrm{~s}$, and to the northeast to 3.5 seconds (TWTT) (Figure 30).

In sub-basin 3, SB1 varies from 1.7 to 4.3 seconds (TWTT). A prominent syncline (Sy-d) trends $\mathrm{N} 30^{\circ} \mathrm{E}$ (Figure 30) that shallows to the southwest to 1.7 seconds (TWTT) (Figure 25).

SB1 is the shallowest values in the Araza High, where it ranges from 2.7 to 3.3 seconds (TWTT) (Figure 30).

The upper sequence boundary (SB2) ranges from 2.6 to 5.2 seconds (TWTT) (Figure 31). The structure is slightly different from SB1.

In Sub-basin 1, SB2 ranges from 3.4 to 4.4 seconds (TWTT). The deepest part is located in Sy-a (4.4 seconds) and shallow uniformly to the northeast (Figures 22, 25, 31); Sy-a trends $\mathrm{N} 45^{\circ} \mathrm{E}$ (Figure 31).

In sub-basin 2, SB2 varies from 4.2 to 5.2 seconds (TWTT). The Sy-b trends N10 $\mathrm{E}$ in the south, is the deepest structure, where SB2 reaches $5.2 \mathrm{~s}$ (Figures 22, 31). The Sy-C is only a half syncline where it is cut to the north by Fault B and a shear fault to the south (Figures 22, 31); it trends $\mathrm{N} 60^{\circ} \mathrm{E}$. A partial anticline (An-a) present to the west, and trends $\mathrm{N} 45^{\circ} \mathrm{W}$, associated with the roll-over structure (Figures 23,31 ), trends $\mathrm{N} 45^{\circ} \mathrm{W}$. In sub-basin 3, SB2 ranges from 3.3 to 4.1 seconds (TWTT). The deepest point is located in the center of Sy-d. The syncline is a partial structure against Fault $\mathrm{C}$ and trends $\mathrm{N} 30^{\circ}$ E (Figures 25, 31). Additionally, the structure has been affected by the normal fault that bisects the syncline into two parts (Figures 23, 31). 
The shallowest values of SB2 are in the Araza High, where they range from 3.5 to 2.7 seconds (TWTT) (Figures 24, 25).

Isochron Map

Sequence 1 varies in time values from 0.05 to 0.9 seconds (TWTT) (Figure 29). In subbasin 1 , the sequence ranges from 0.2 to 0.5 seconds (TWTT), becoming thicker to the northwest. The sequence varies from 0 to 0.85 seconds (TWTT) (Figure 29) in sub-basin 2. A prominent NE trending iso-thick is present in the north and western part of sub-basin 2. The sequence thins and lapouts to the south. In sub-basin 3, the sequence varies from 0.3 to 0.4 seconds. The sequence thins over the Araza High, with time values from 0 to 0.15 seconds (TWTT).

$\underline{\text { Seismic Facies (Internal Description) }}$

The seismic facies vary in each sub-basin (Figures 26 - 28). Sub-basin 1 is characterized by facies changes from the north to the south, from moderate continuous reflections to reflections with low continuity and low amplitudes (Figure 26). The geometry reflections are lens to subparallel, and internal onlap is present. These facies are interpreted as a series of stacked channel-fill systems. Subtle paleo-topography is present and internal onlap is imaged over the basal erosive surface. Two horizon slices of sequence 1, displaying 0.1 and 0.4 seconds (TWTT) beneath SB2, are shown in Figures 32 and $\mathbf{3 3}$, respectively. The 0.1 seconds (TWTT) map images the shallower portion of sequence 1 , and is typified by more continuous reflections to the northeast associated to a lobe. The variable seismic pattern to the east is the channel-fill offset system.

Sequence 1 in Sub-basin 2 thickens considerably south of Fault B. The sequence overlies a highly deformed zone TS1, and onlaps the paleohighs. Four prominent clinoforms are 
distinguishable from the southeast to the northwest of the sub-basin (Figure 27); the facies consist of subparallel reflections with low amplitude and moderate frequency. Subtle onlap and phase changes in the reflections likely indicate the presence of channelfill sediments (Figure 27).

In Sub-basin 3, sequence 1 is characterized by lens to subparallel reflection units with fair continuity and moderate amplitude. Several erosional stacked channels are present that are laterally offset (Figure 28).

Geologic Interpretation

The variable thickness of $\mathrm{S} 1$ within the three sub-basins (Figure 29) is due to consequently syndeposit normal faulting (strike-slip faults) and variations subsidence.

The offset channel geometries in Sub-basin 1 and multiple erosional surfaces of the channel patterns facies, indicates the subtle variation in the paleobathymetry (Figure 26).

In Sub-basin 2 has the thickest part for the sequence and consequently the oldest sediments deposited. Stacked clinoforms to the northwest represent periodic sediment inputs, where fill the iso-thick part of the sub-basin adjacent to Fault B (Figure 27). Likely, a filling stepping migration start to the west and migrates to the east by stacked confined lobe geometries (Figure 33).

In Sub-basin 3, several stacked channelized lenses approximately of 500m of width are present lapping out to the southeast (Figure 28). 


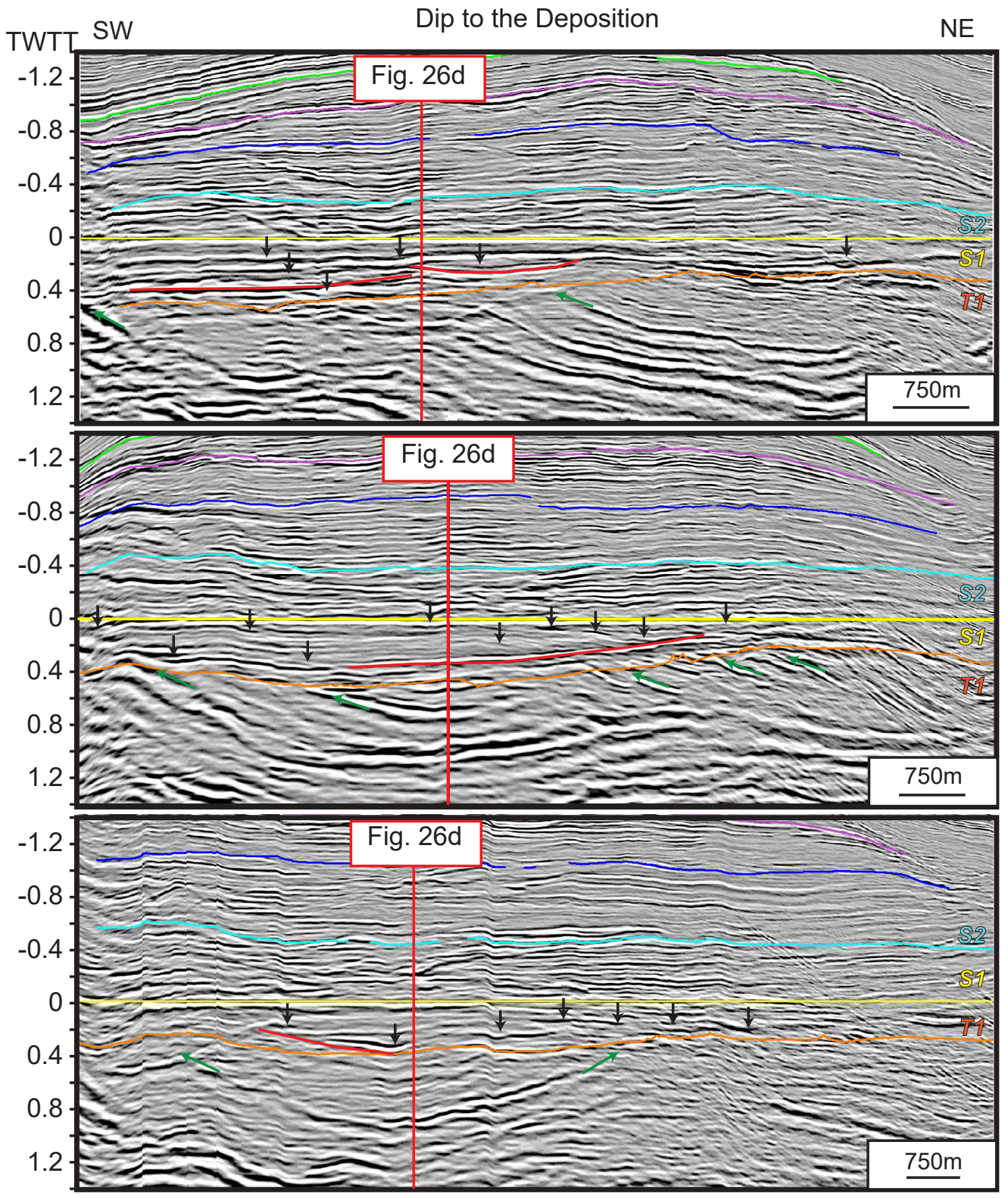

(a)

()

(I)

$\dot{ }$

$m$

윽 요

๑ 0

心

은 으

তে

(b)

(8)

ญ

뜰

ठ ल

(1)

으 으

年

응

の

3

응음

(c) \

웅

क

ㄷำ

유

\&.

훙

気

证

ह

ब응

응

$\stackrel{\oplus}{\sigma}$

Ф)

NW

Strike to the Deposition

SE

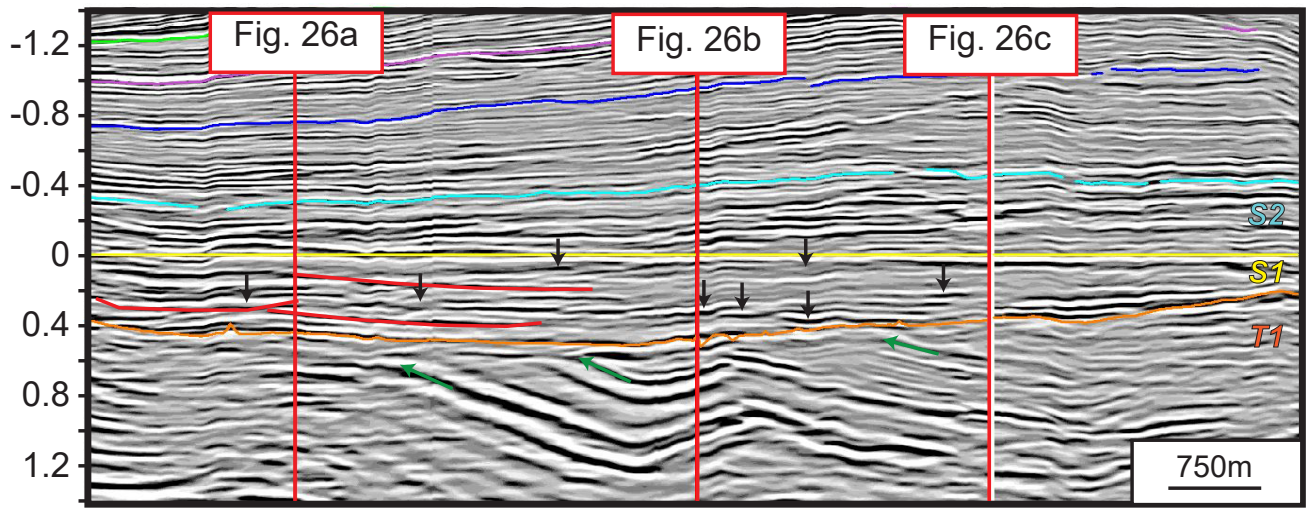

(d)

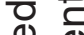

屯

흔 응

Ф)

竞

N

는

음 


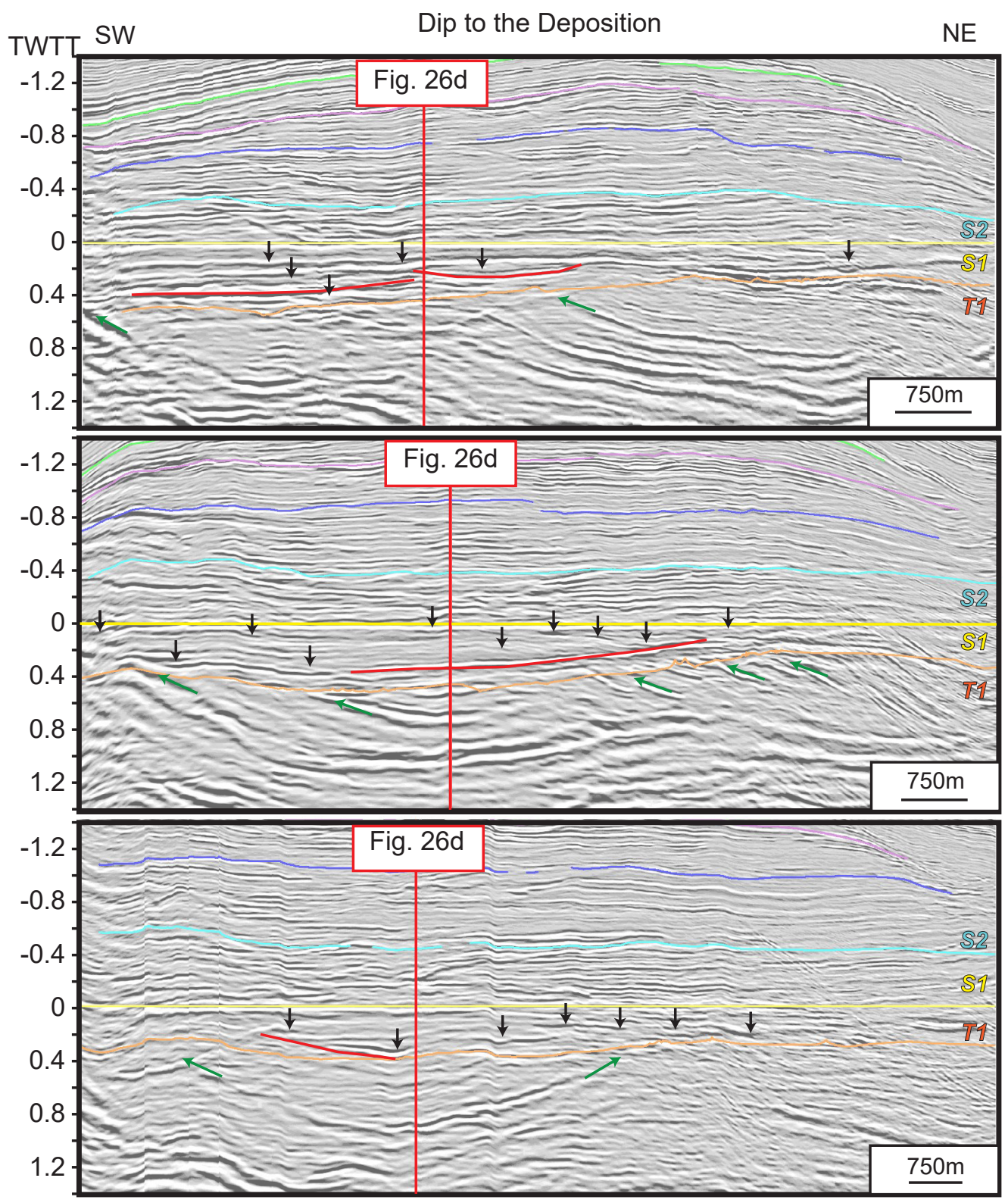

(a)

음 $\frac{\frac{2}{0}}{\frac{7}{0}}$

(등 즈으

...

它 N

음

ऽ Ф U

ஸ তু তে

(b)

응 은

তে $\cong$ ฯ

-

ษ 은

ธே ธ

(1)

흐은 응

๘

ర) ๕

들 드름 응

ว 등

心 은

(c)

उ

으 @

¿

늘 슨

$m$ 드음.

ᄃ ত

든 응 음

떤 은 릉

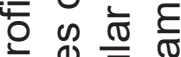

느리

을 흔

ह थ

ต

ผ ర

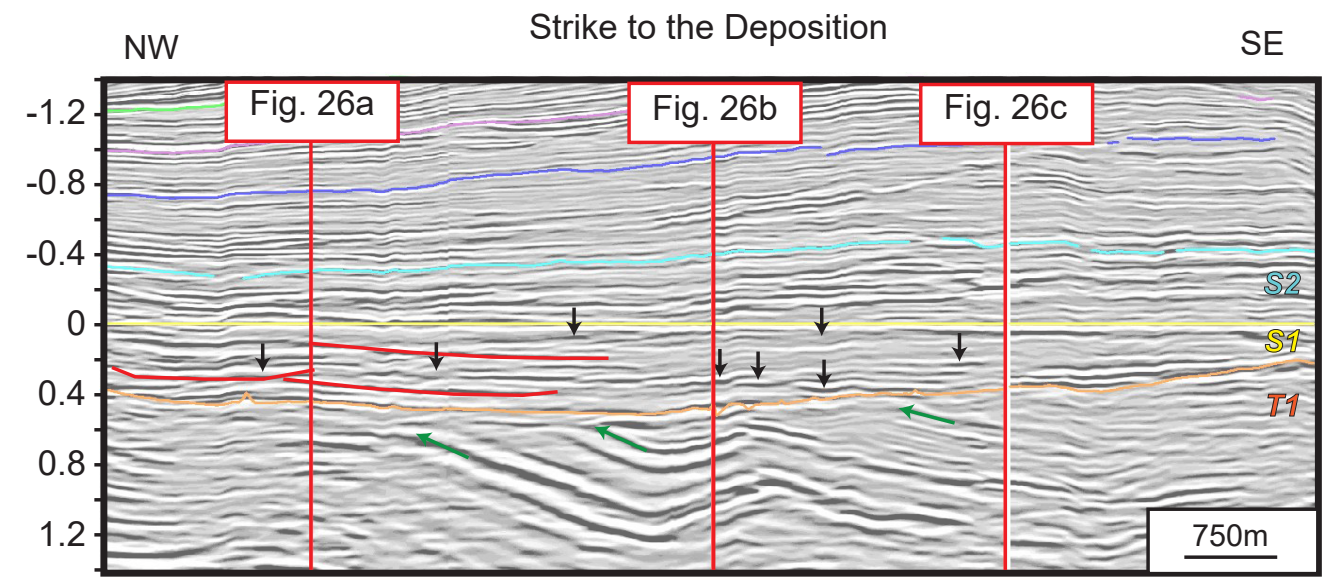

ర드 응

ฮั ธิ ๓

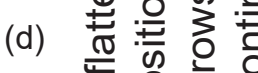

4 은

d

प)

은 든 인

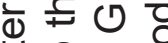

드 으

๑ 등 이

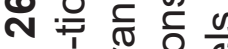

(1) 넌 응 을

는 엉

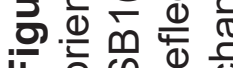




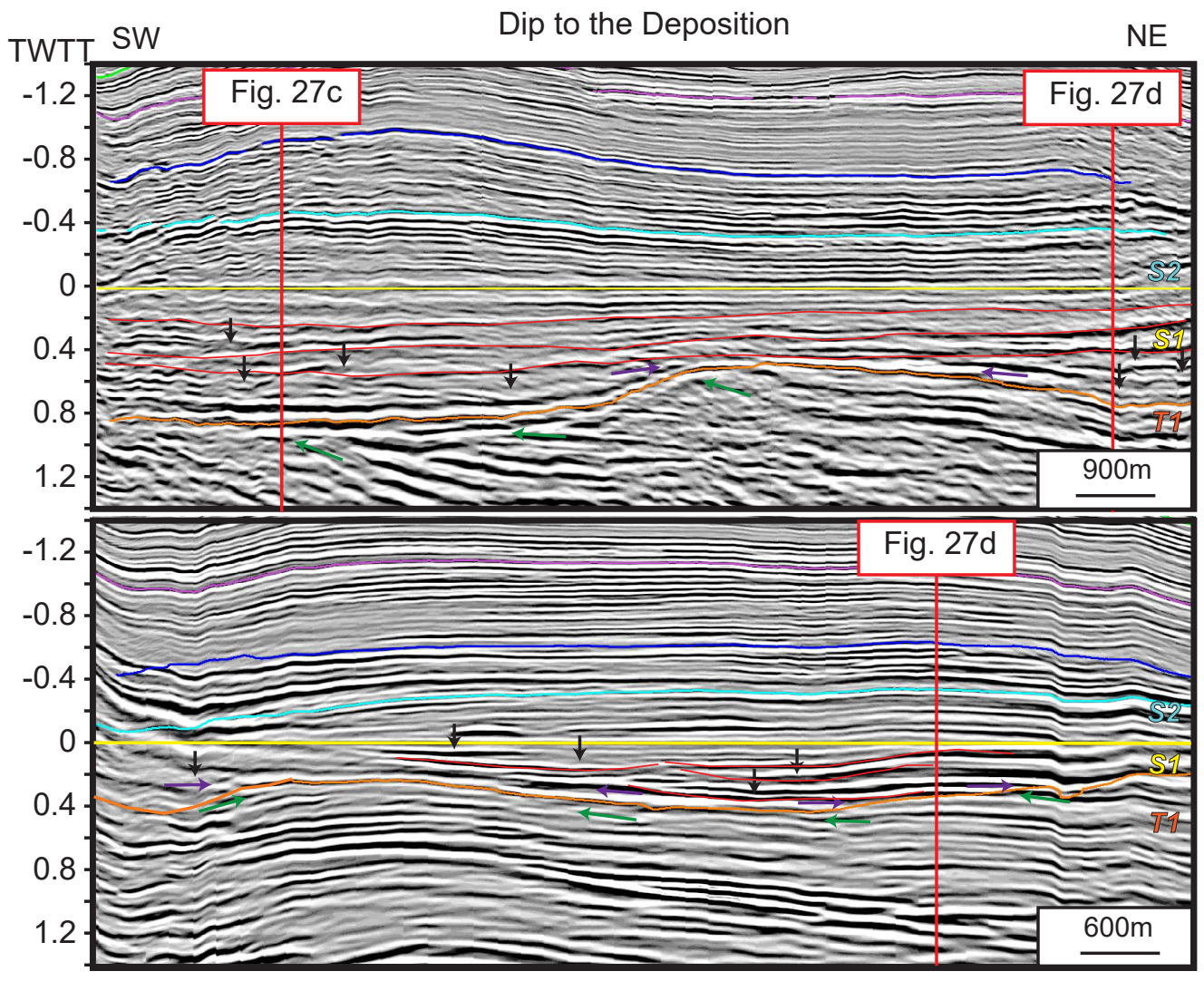

(a)

ज

อำ

(I)

ì

윽 우

ज

ஸิ 즘

인 은

ช .

(b) $\sigma$

¿ ర

बक

후 으

ल

을으

可

으모

的

วิ

ब $\frac{1}{0}$

$\geqslant 0$

๓

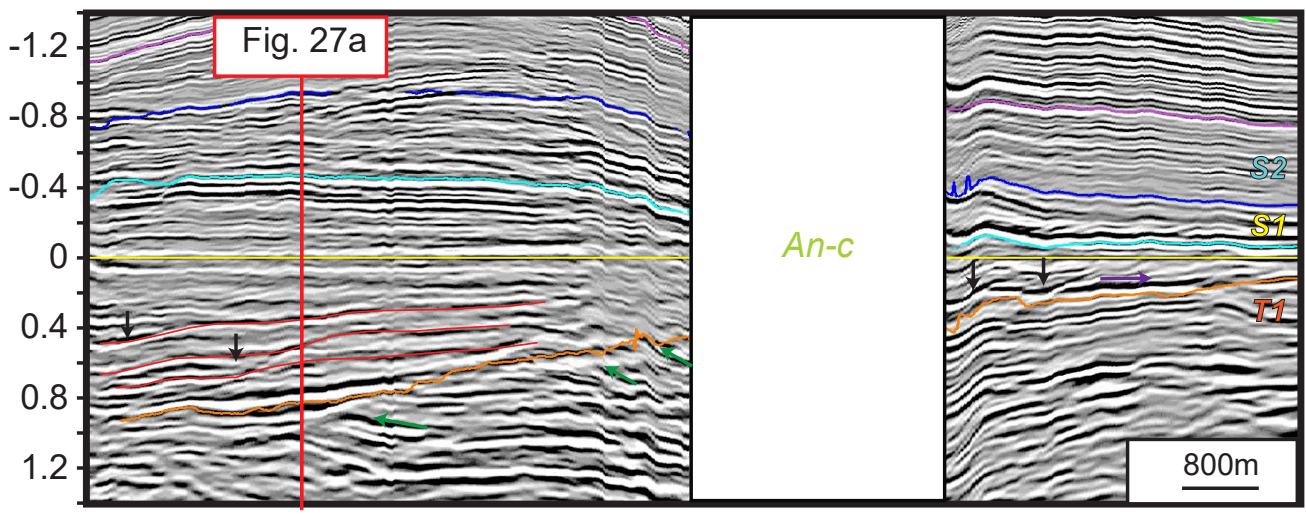

(c) 등 뜜

d)

웅

응 뽀

을

के

ग

क 0

웡므

저

䒕 등

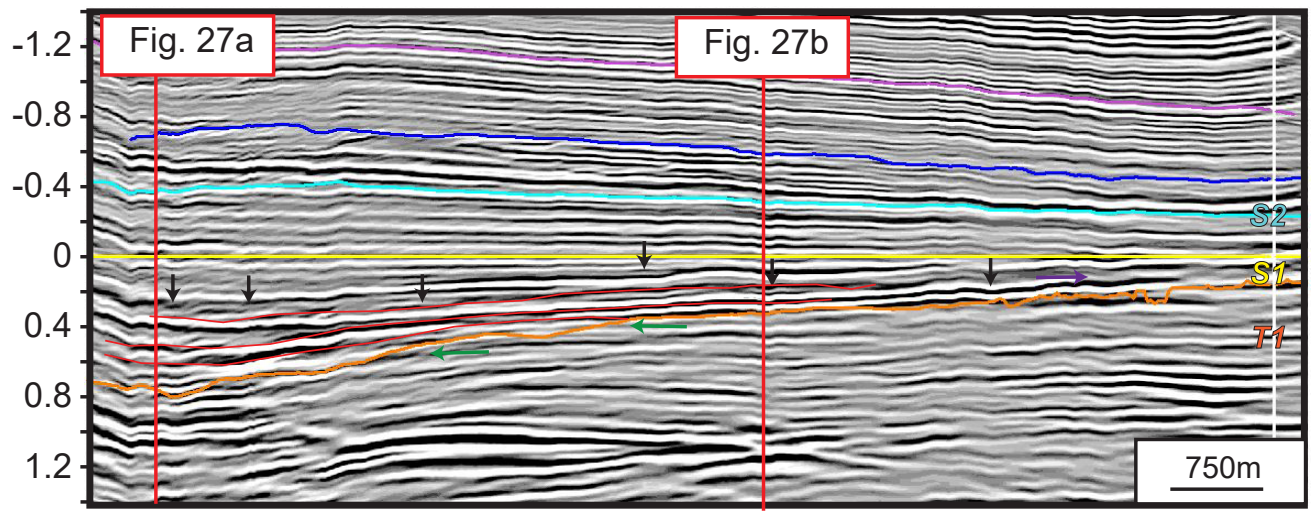

(d)

띤

응 중

놈 음

등

ऽ

N

ఏ

은

은 

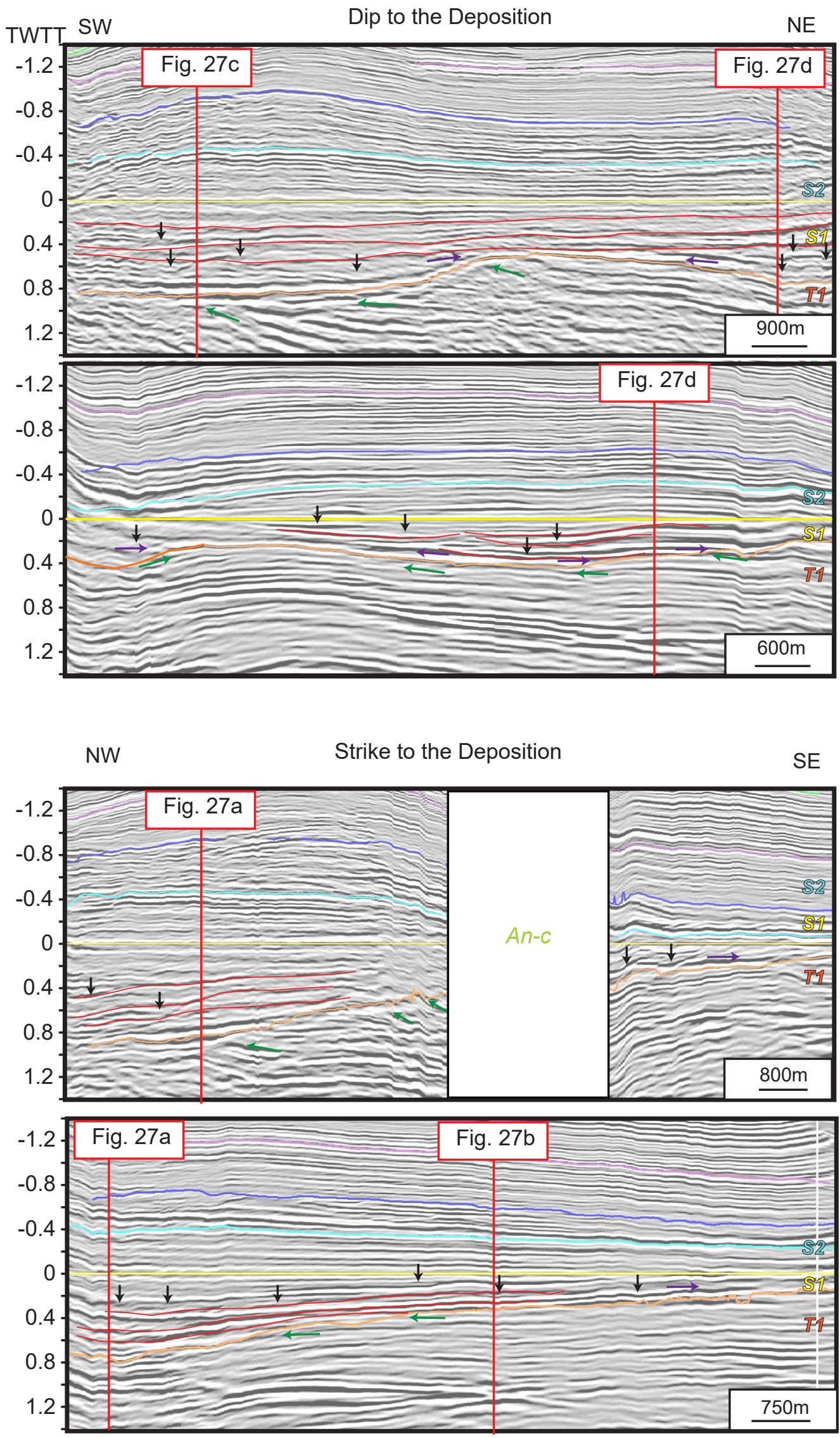

(a)

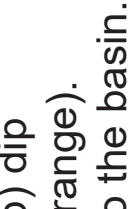
으힌 은 (ब) $\therefore$ Q i 1 응응 ज $\frac{\text { ब }}{\frac{1}{C}}$ क ब (b) 융 d 증 - . 응 (1) $\infty$ บ ब 잉 금 ஸ 인 뭉 ३ ह 드은 든 क : ३

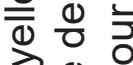

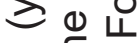
(c) $\cong$. c) $\stackrel{m}{\omega} \div$ ᄃ ๘ ᄃ웡 的艺 (1) 产 흥 (1) 을 을 흥 है के क응 우 क ' ○니능 응

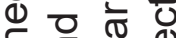

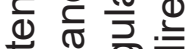
(d) 世 으 주 ठ $\stackrel{9}{10}$ 응ㅎㅁ응 (ब) $\subseteq 0$ (1) 心 도 3 त 숭ㅇ 은 응 N ఏ Ф 등 늘 믄 인 는인 

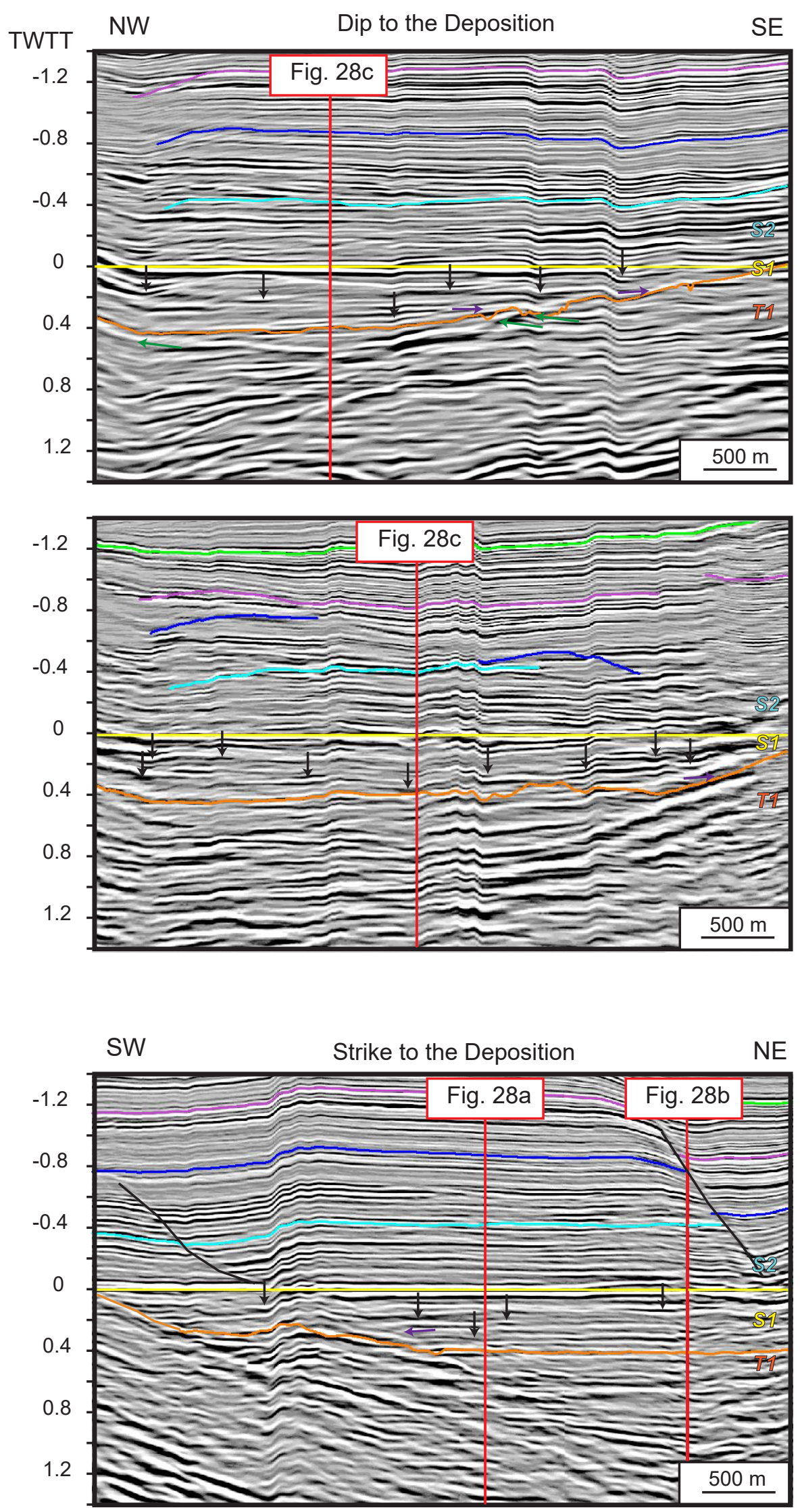

(a)

อิ

(ర)

$\ddot{m}$

$m$

윽 옹

क

을 음

过

$\leftarrow . \subseteq$

(1)

잉

क

요

(b)

은

독 음

ठठ

क व

음

(1) 잉

$\geq \frac{0}{0}$

ํㅇ

の

등 음

क

운

응

으 임

을 竞

ब)

क

(c) ठ 다

雱 은

元

잉

ฮั

은.음

힘

䓂

$\stackrel{\infty}{\sim}$

는

은 


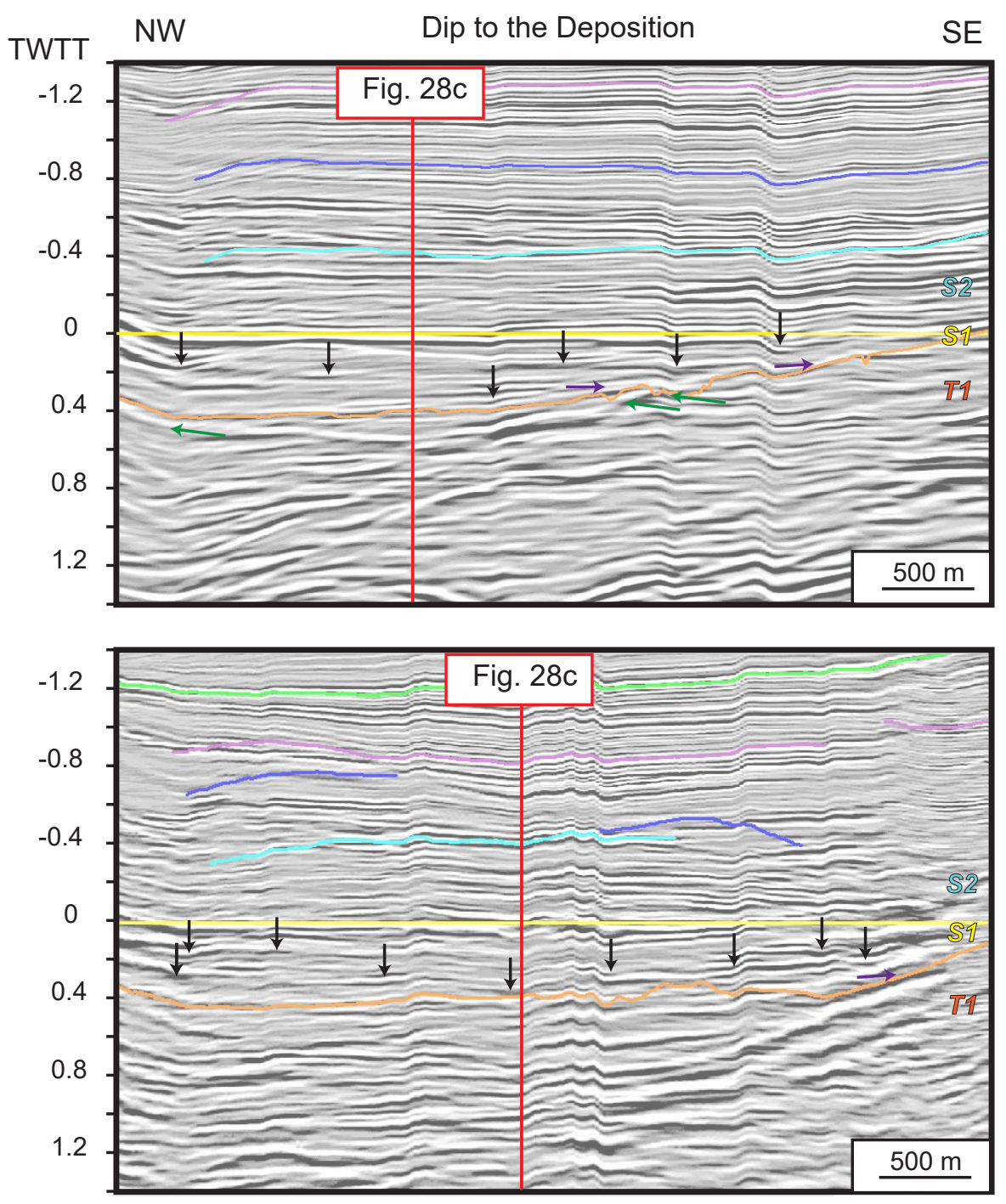

(a)

(b)

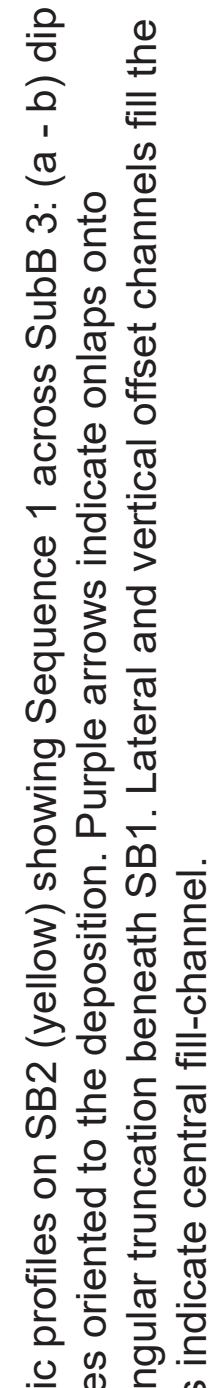

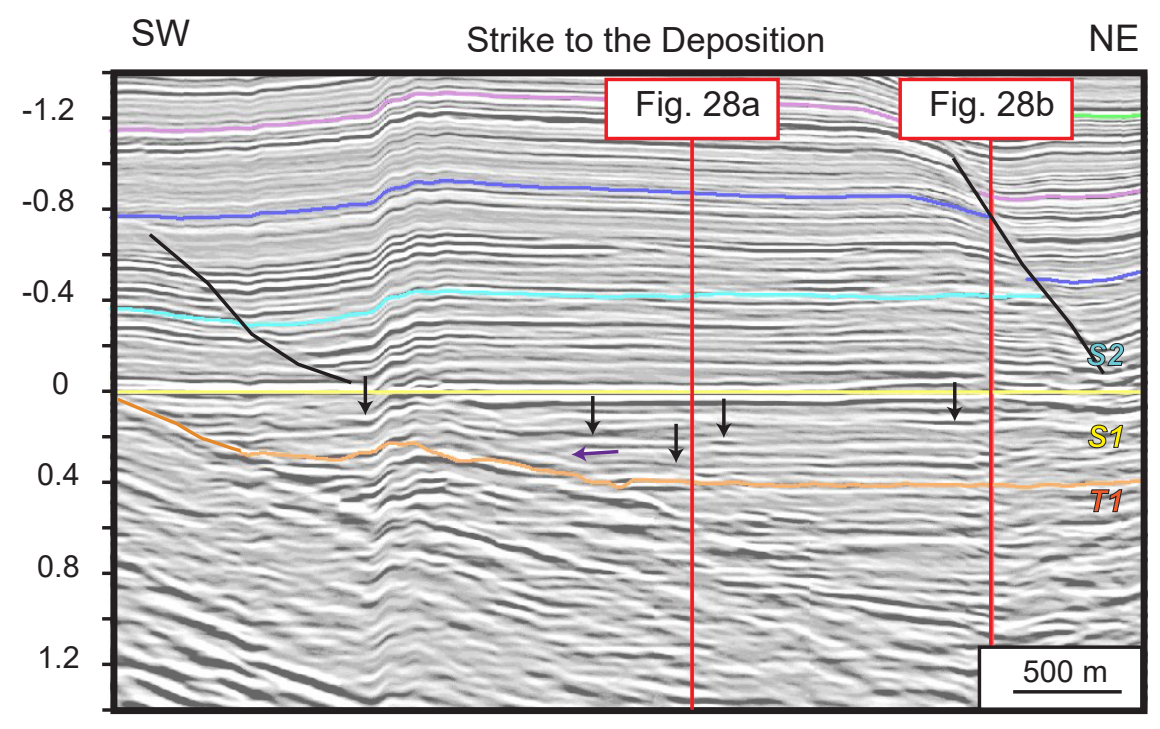

(c)

ह ㄷํㄹ

क

क Oิ

어은

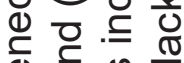

ब $\frac{1}{2} \frac{\pi}{\infty}$

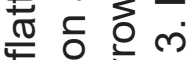

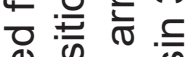

屯ำ

흥 ᅯ

이잉

$\subseteq \stackrel{\dot{0}}{\subseteq}$

$\infty$ 웅

기 ర

닌

둥

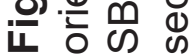




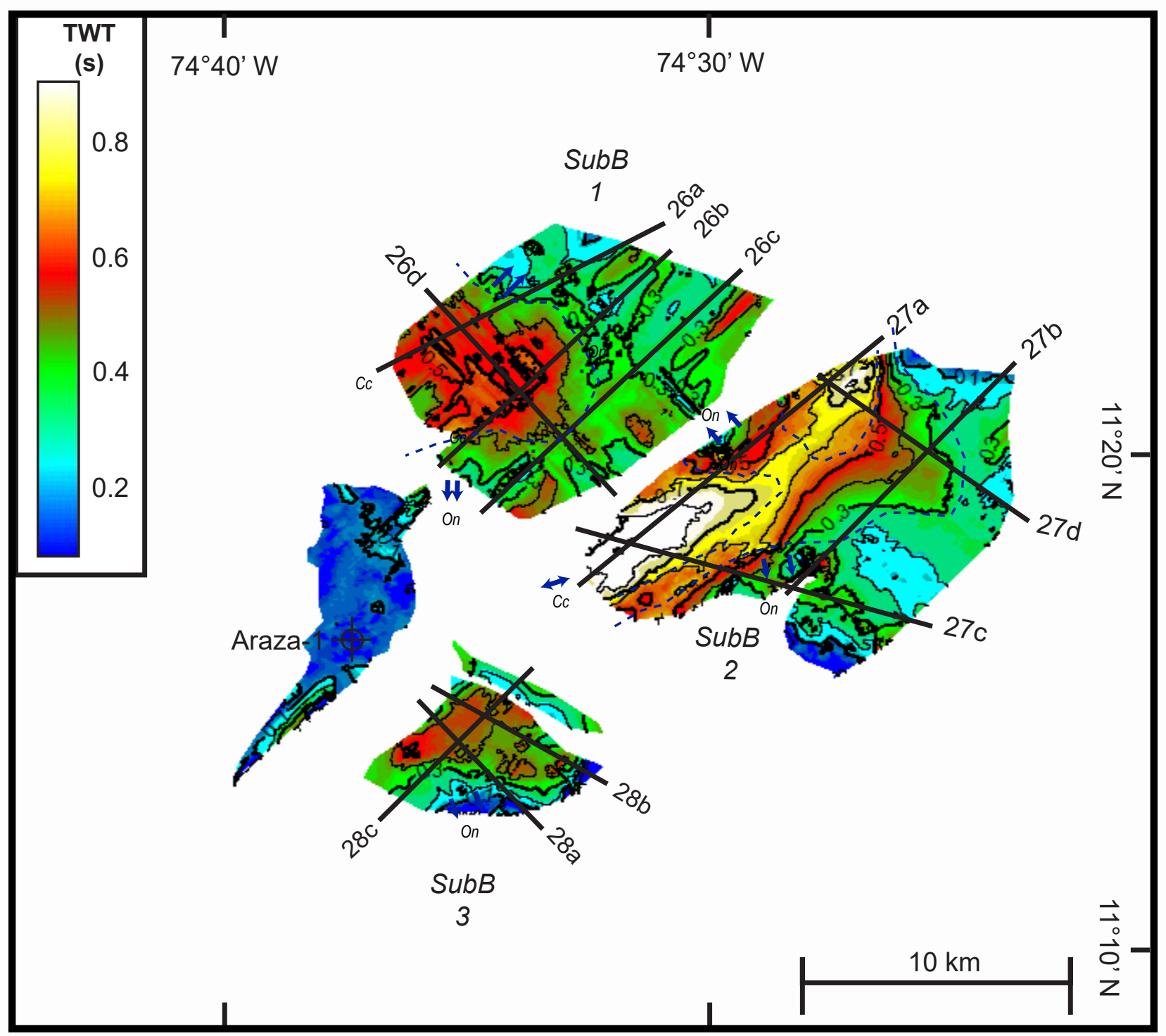

Figure 29. Isochron map of Sequence 1. Warm colors indicate thicker areas. Contour interval is 0.05 seconds (TWTT). Blue arrows indicate onlap direction. Dashed lines show transition from concordand to onlapping reflections. On: Onlap Cc: Concordant. 


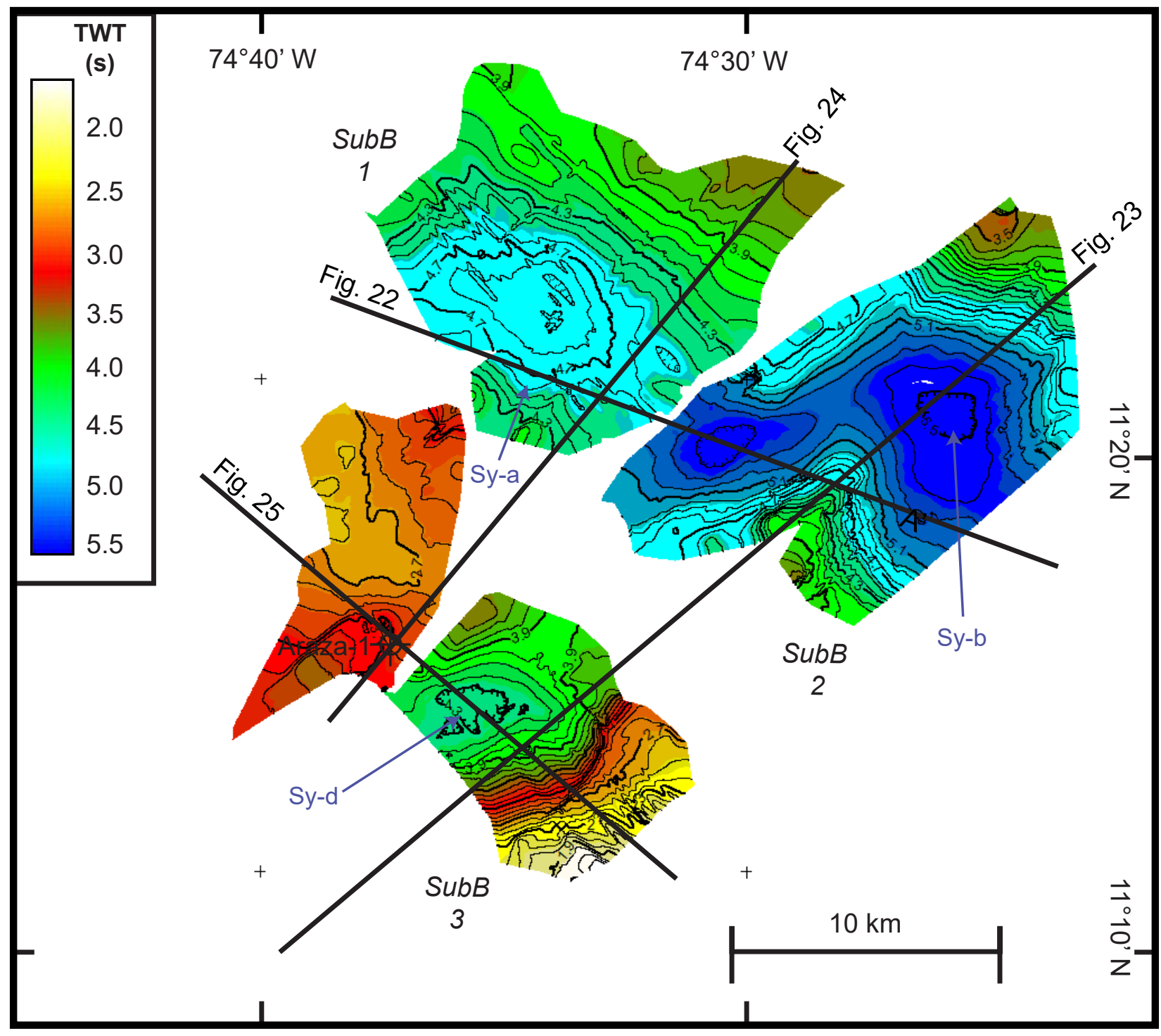

Figure 30. Time structure map at base of Sequence 1 (SB1). Warm colors indicate structural highs and cool colors lows areas. Contour interval 0.1 seconds (TWTT). Anticlines (An) and Synclines (Sy) are labeled. 


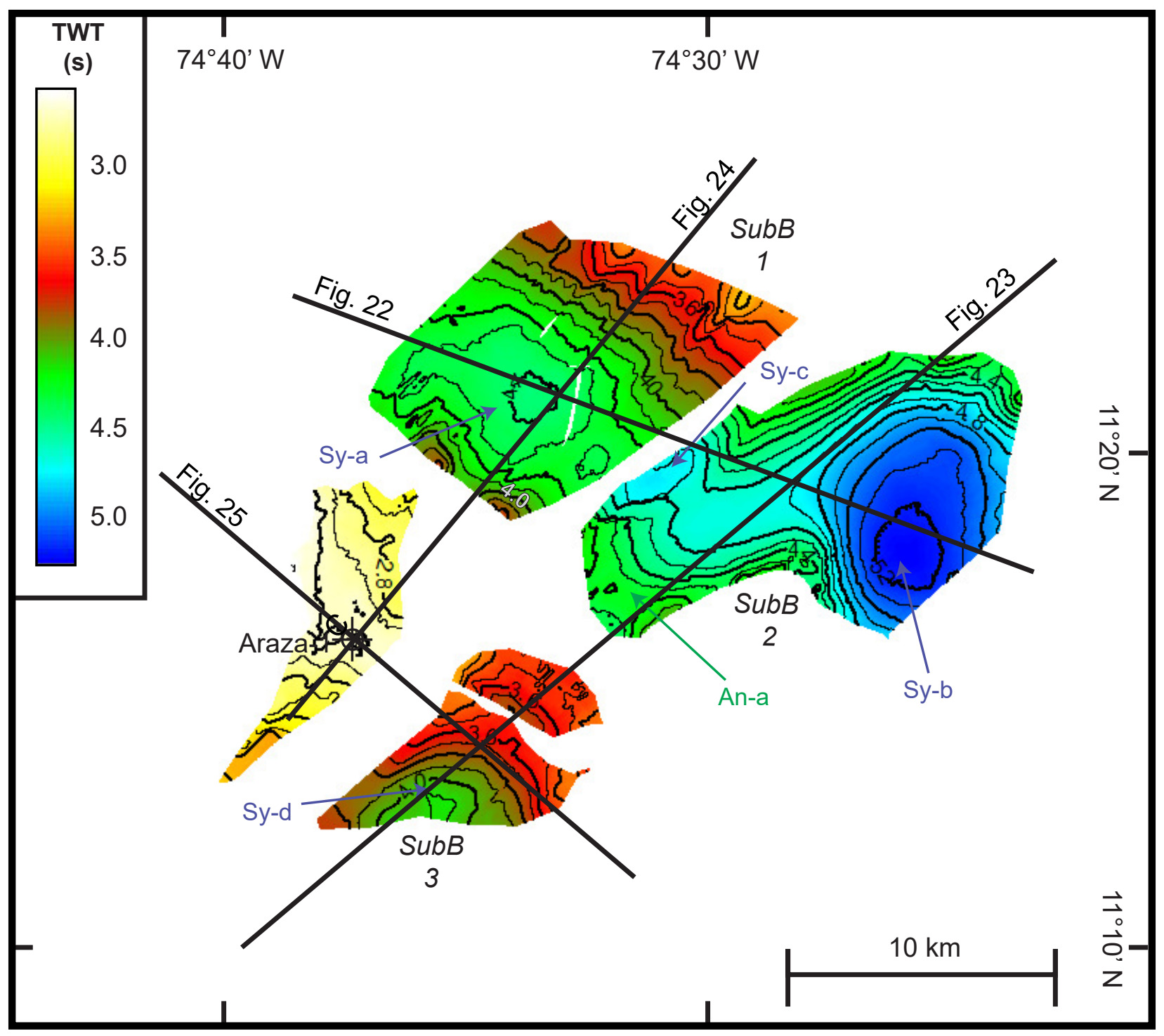

Figure 31. Time structure map at top of Sequence 1 (SB2). Warm colors indicate structural highs and cool colors lows areas. Contour interval 0.1 seconds (TWTT). Anticlines (An) and Synclines (Sy) are labeled. 


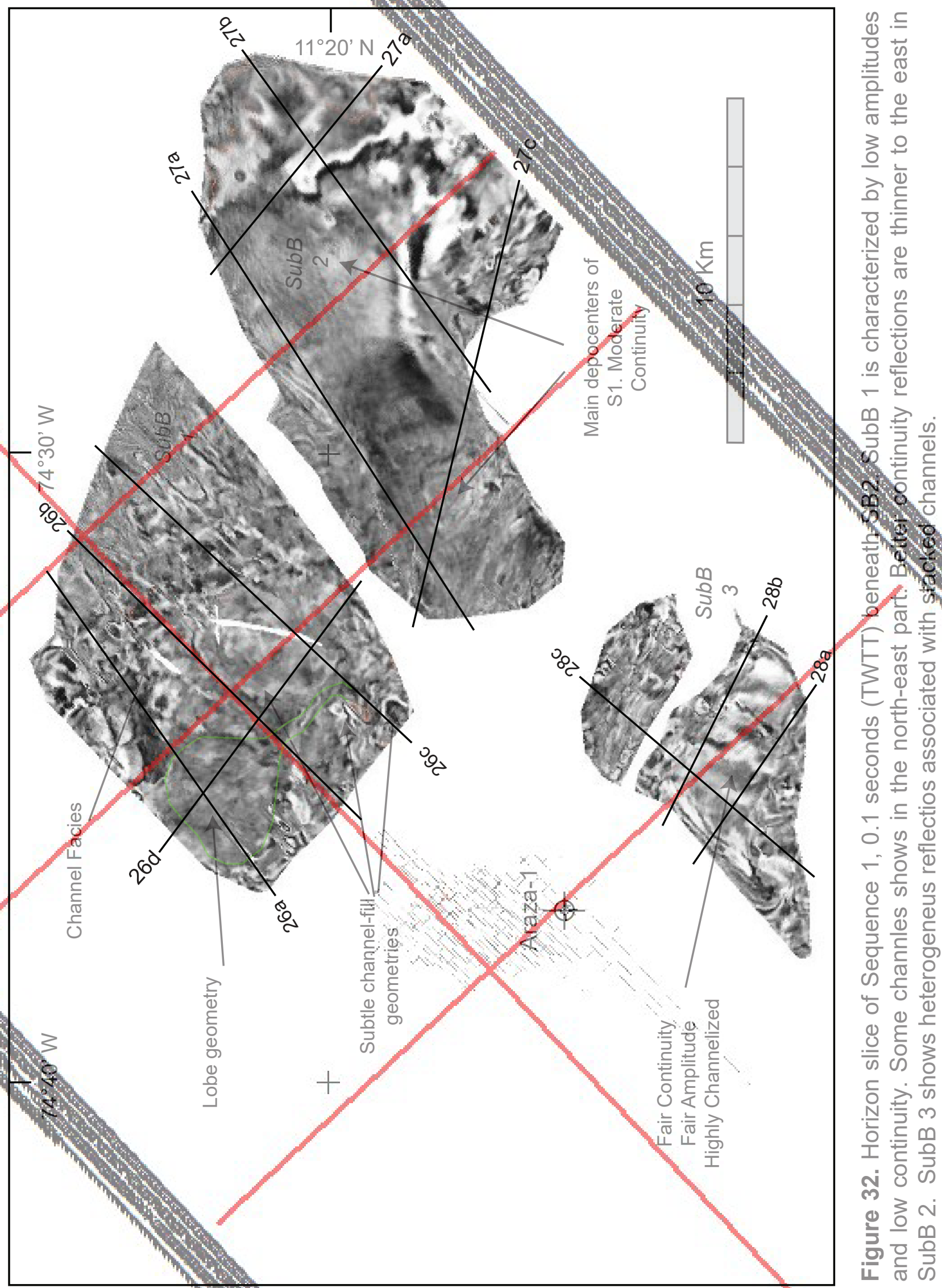




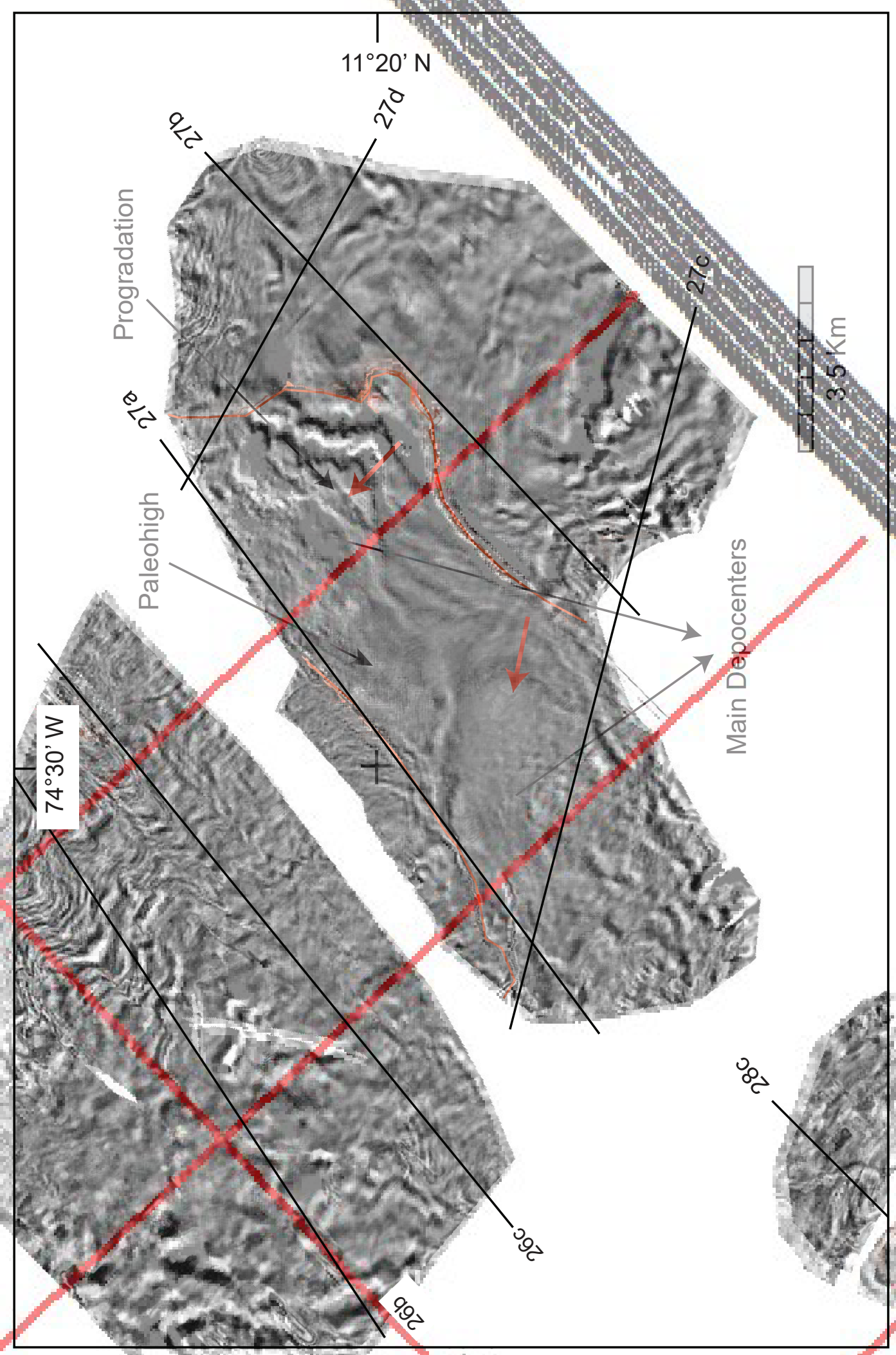

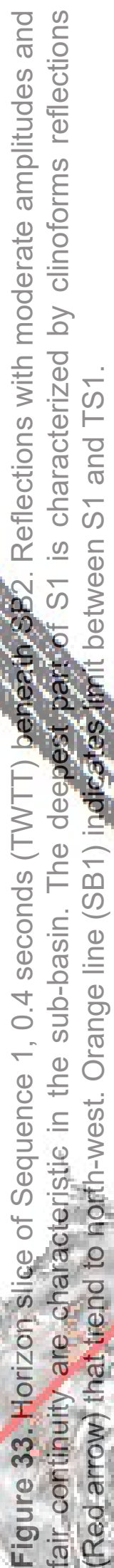




\section{Sequence 2}

\section{Key Surfaces}

In sub-basin 1, sequence reflections onlap on SB2 to the north-west. To the SE, near to Fault B, the reflections are concordant with the lower sequence boundary (Figures 34 37). In sub-basin 2, the reflections onlap onto SB2 in the southern part (Figures $\mathbf{3 4 , 3 7 \text { ) }}$ and northern part of the sub-basin (Figure 37). In the east-central portions of the subbasin, the reflections are concordant above SB2 (Figures 35,37 ). In sub-basin 3, the reflections are concordant overlying the lower sequence boundary. At the north-eastern part, the basal reflections are fault offset against the TS1 (Figures $36-37$ ). In all three sub-basins, the upper reflections are concordant with SB3.

\section{$\underline{\text { Time-Structure Map }}$}

The upper sequence boundary 3 (SB3) ranges from 2.4 to 5.0 seconds (TWTT) (Figure 38). In sub-basin 1, SB3 ranges from 3.2 to 4.0 seconds (TWTT). A prominent syncline (Sy-a) structure, trending $\mathrm{N} 60^{\circ} \mathrm{W}$, is in the western part of the sub-basin. The deepest part is in the axis of the syncline (Figures 22, 25, 38), and synclinal axis is offset slightly to the north, in contrast to the SB2 structure. Sub-basin 3 shallows gradually to the northeast until 3.5 seconds (TWTT) to the SW (Figures 24, 38).

In sub-basin 2, SB3 ranges from 3.7 to 5.0 seconds (TWTT). A prominent north trading syncline (Sy-b) is present to the south, where SB3 reaches 5.0 seconds (TWTT) north trending (Figures 22, 38). The synclinal axis is slightly south compared with SB2 (Figure 38); SB2 shallows gradually to the northern and western parts of the sub-basin (An-a and An-b). 
In sub-basin 3, SB3 ranges from 3.1 to 3.8 seconds (TWTT). The horizon dips to the southwest, becoming deepest at 3.8 seconds (TWTT) in syncline (Sy-d), which trends N $50^{\circ} \mathrm{E}$ (Figures 25, 38). The NW striking listric fault cuts the syncline causing overall deepening (Figures 23, 38). SB2 is shallowest across the Araza High, where ranges from 3.0 to 2.4 seconds (TWTT) (Figures 24 - 25).

Isochron Map

Sequence 2 varies in time values from 0.05 to 0.55 seconds (TWTT) (Figure 37). In subbasin 1 , the sequence ranges from 0.05 to 0.55 seconds (TWTT), with NE trending isothick adjacent to Fault B in the south-east part of the basin (Figure 37). The sequence thins to the northwest and northeast.

In sub-basin 2, sequence 2 varies from 0.1 to 0.45 seconds (TWTT). The thickest part is to the west adjacent to the normal fault, with an iso-thick that trends to the NE. The sediments thin to the east and south (Figure 37).

In sub-basin 3, sequence 2 varies from 0.3 to 0.5 seconds (TWTT). The greatest thickness means in the central part trends NNE. The sequence has a similar thickness in the center and west, and thins to the southeast and southwest (Figure 37).

The area of the Araza High has the lowest time values ranging from 0.05 to 0.2 seconds. (TWTT).

\section{Seismic Facies (Internal Description)}

In sub-basin 1, sequence 1 is characterized by prominent lens to subparallel reflections with subtle onlap. Lateral and vertical offset channalized geometries along the sub-basin characterize the sequence (Figure 34). Prominent erosional surfaces cut across the 
reflections. The horizon slice at 0.2 seconds (TWTT) beneath SB3 shows heterogeneous facies patterns across sub-basin 1 (Figure 39); these support the laterally offset variation of multiple channel systems that develop in sequence 2 .

Sub-Basin 2 shows dominantly subparallel reflections with good continuity and subtle lateral shift phase along the area (Figure 35). Sequence 2 thins and onlaps to the east onto SB2 (Figure 35). The subparallel reflections correspond to channel-fill sediments; flanking levee geometries have higher continuous reflections (Figure 35). There is considerable lateral shifting in the channels that the horizon map shows lateral variation of facies patterns with moderate amplitudes (Figure 39). The high continuity reflections represent the levees and the low continuity reflections indicate the channel-fill.

Three internal units (1-3) are present in sub-basin 3. Unit 1 has subparallel reflections, with good continuity and moderate amplitude (Figure 36). This unit onlaps to the west onto SB1 and TS1. Unit 2 is characterized by less continuous reflections with subtle lateral amplitude shift (Figure 36). Reflections with less continuity represent the channel-fill geometries and the more continuous reflections represent the levees. The channel geometries migrate laterally. The thickness of Unit 2 is relatively constant along sub-basin 2. In the western part, the unit overlies TS1. Unit 3 is present to the south and onlaps to the north; It is characterized by discontinuous reflections and low amplitudes (Figure 36). The horizon map displays a lobe geometry at the level of Unit 2 (Figure 39). The lobe trends to the north and varies to the northwest (Figure 39).

Geologic Interpretation

In sub-basin1, sequence 2 is a channelized unit with many erosional surfaces (Figure 34). The width of these erosional lenses are approximately $2 \mathrm{~km}$ and the time values area 


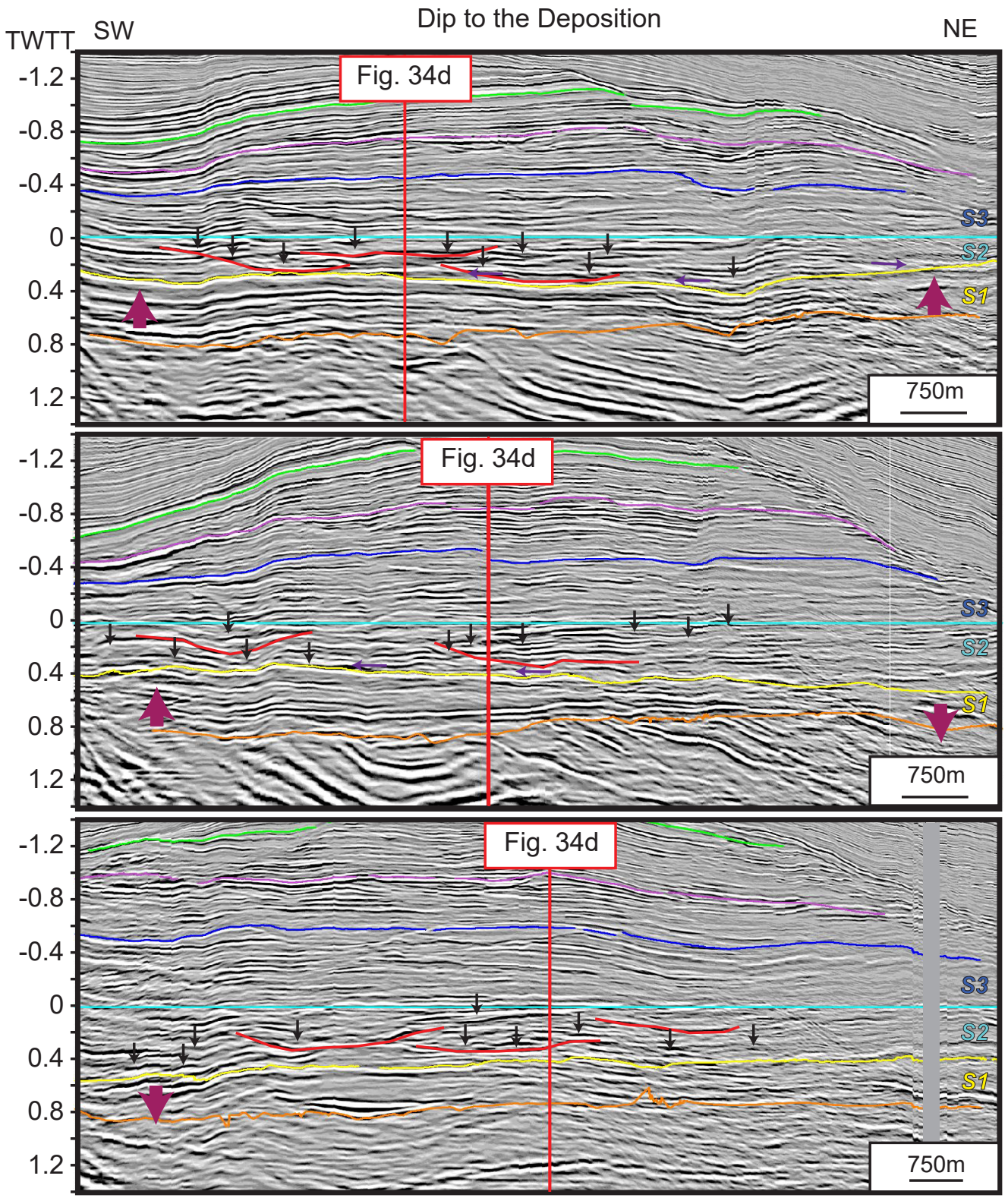

(a)

(1)

$\therefore$

$m$

윽

ज

ल ఖ

늠 믄

N.ᄃ

过

(b) $\frac{\bar{d}}{\frac{\sigma}{0}} \frac{0}{\omega}$

(1)

$\omega$ 品

은

들 음

ว

ज

(ิ)

긍ํㅇ

드 d

흐 무

(c) $m$

( ) :을

등 꼰

क) 은

응

흘

章

के

ब)

क 음

하

ธิ 음

त

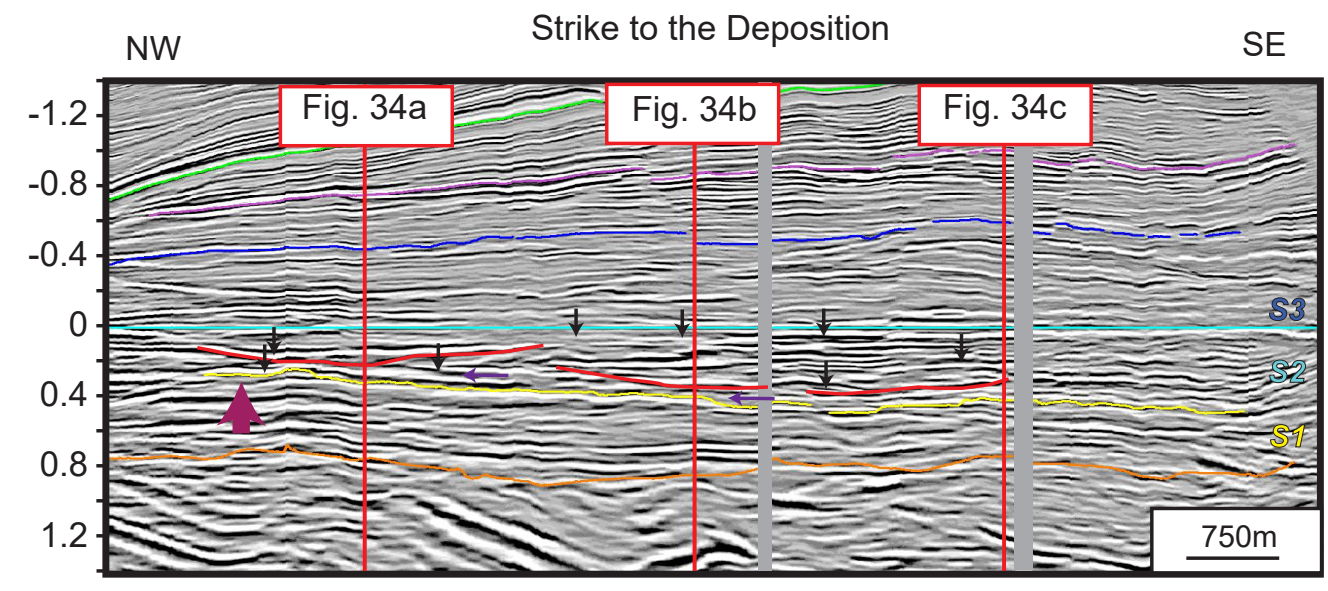

응

(d) ฮ응

은 응

这

를

5 क

ن

ले

닌

음

i 


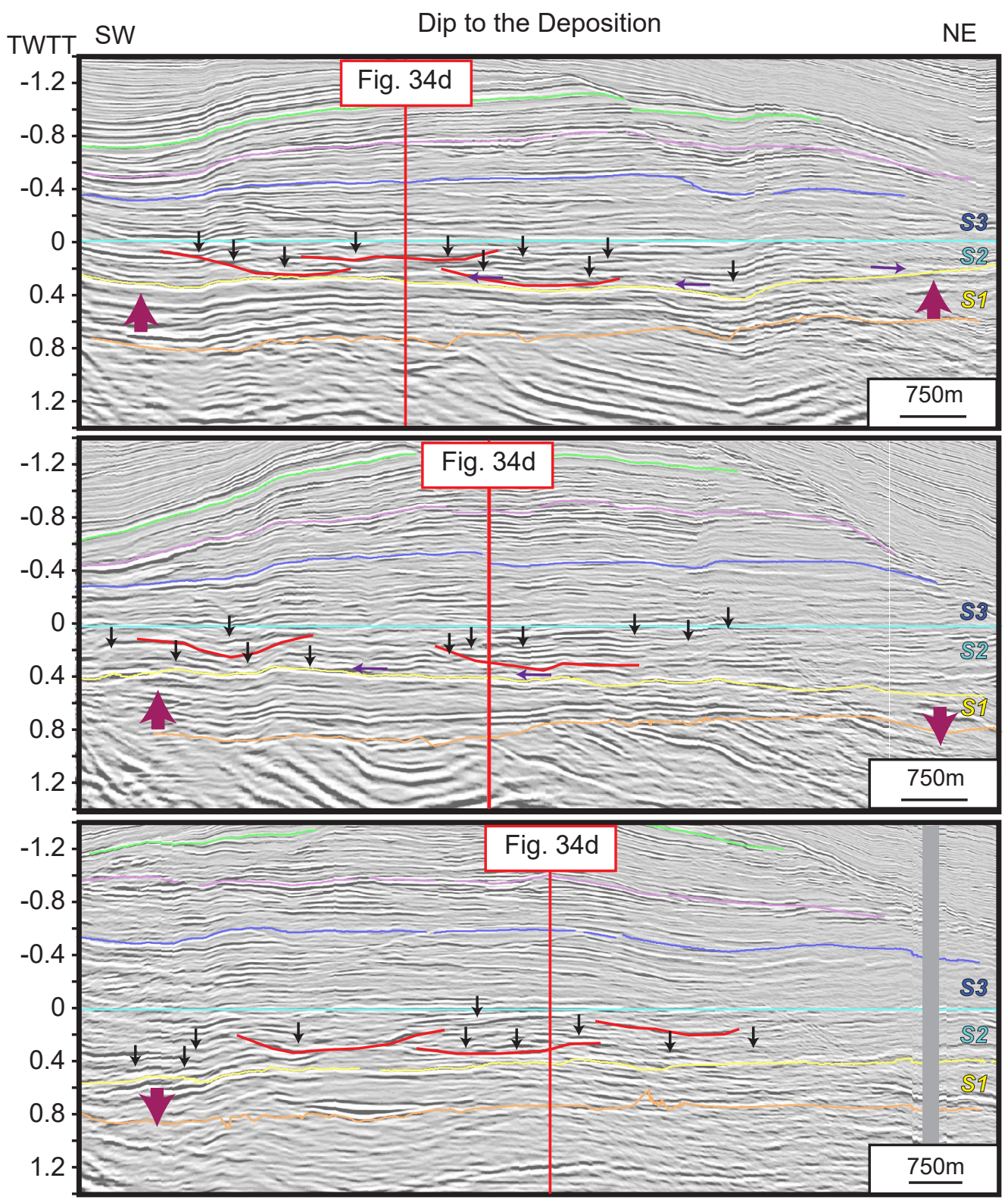

(a)

읗 $\dot{3} \overline{0}$ o음 $x$

$1 \stackrel{0}{ \pm}$ 放 (1) $\because \widetilde{\infty} \stackrel{\square}{\square}$ ๓ $\frac{2}{\pi}$ क ธิ क : क त 응 엉 (b) $\approx$ $N$ 䒕 ه ब. $\subseteq \stackrel{2}{\simeq}$ 웅 $\infty$ ब 3 फ 은 ठ๘ 乐 인 क व

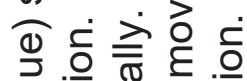
(c) 递

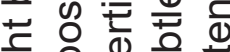
응 웡 $>$ 음 要 万人 000 品 엉 오 융 흥 б 0 क $ᄃ$ $\infty$ 造 证 응 흥 万人 0 \& $\frac{v}{0}$ $\varepsilon$ 政 क

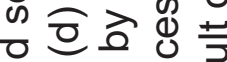

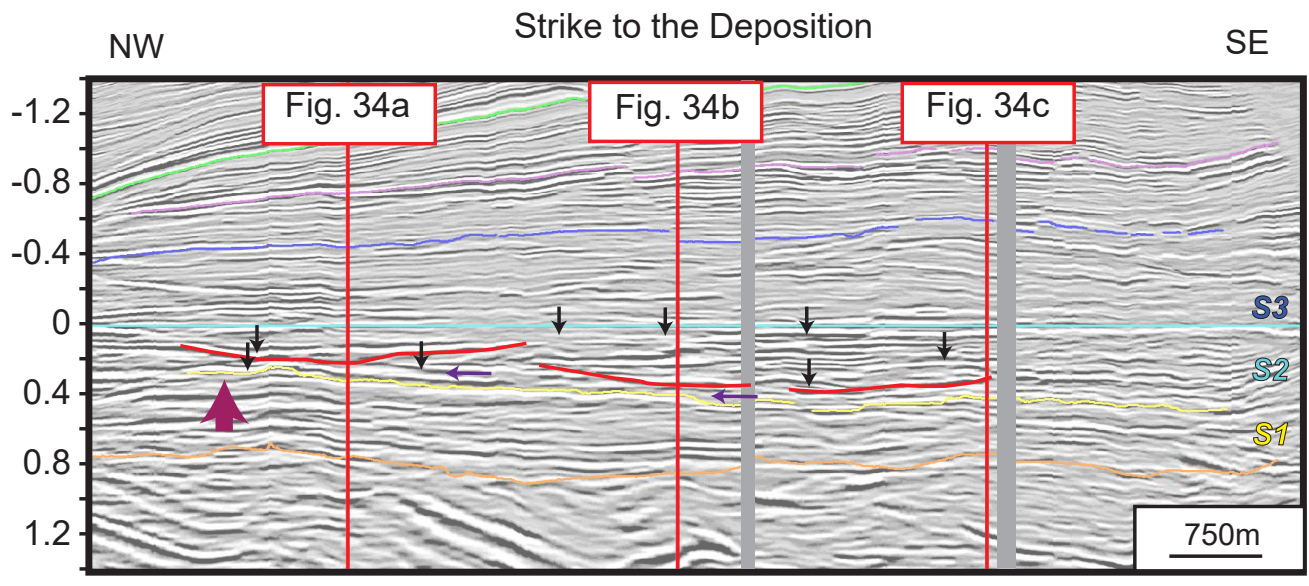

$\Phi$ 유

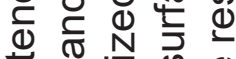
(d) 4 음 $\overline{0}$ 원 ब ¿ 응 흔용 으 (ब) 吉 엏 $\forall$ 어 m 긍

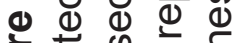

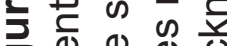
이 은 도을 

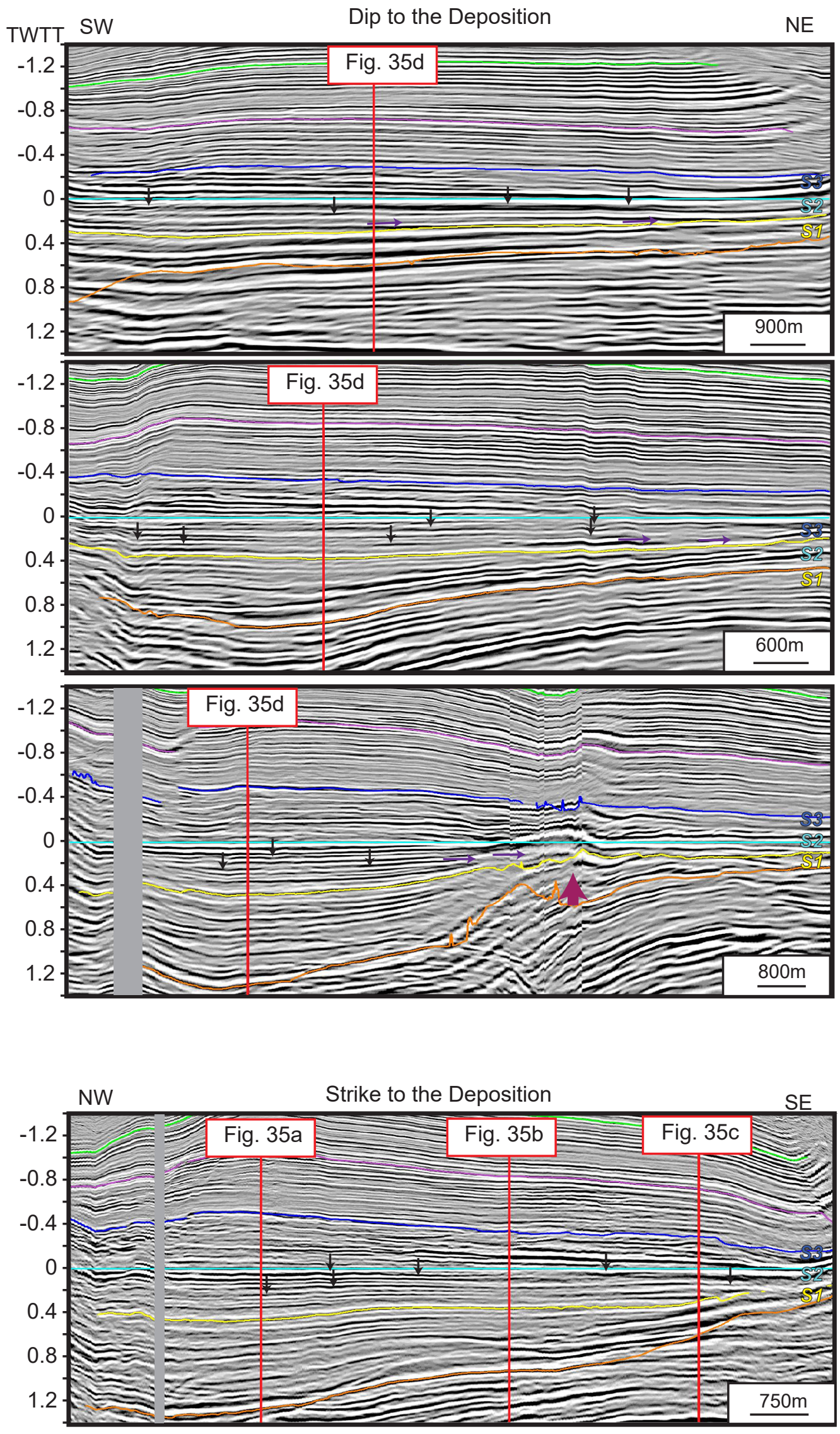

(a)

(ర)

กi

$m$

号

ज

क 인

을

닌으

$N \subseteq$

乌 ᄃ

(b) $\frac{1}{\partial}$ 음

ఖ

O

$\stackrel{ }{\equiv}$

ว

ज

(1)

긍

도

흥 응

(c)

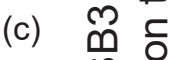

๗ 을

ᄃ

क)

d 응

능 क

느논

을 혼

क

ब음

थ ర

ర్త

등

플

은

이

(1)

(d)

은 응

包

.

ज

ம0

ल

(1)

3

오 

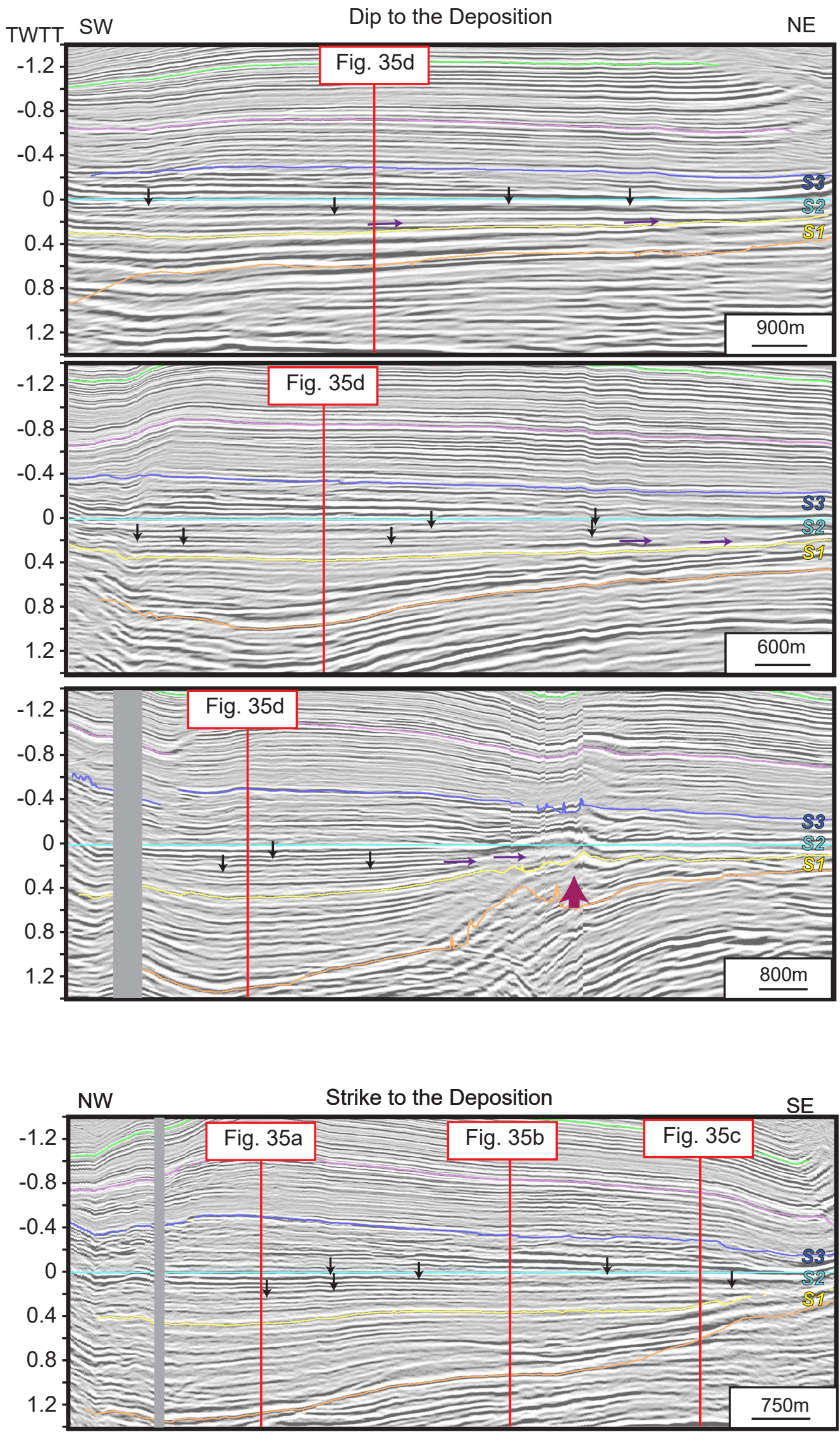

(b)

(a)

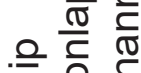
응 ช 1 (c) तi 덩 뭉 윽 오 क $\frac{d}{4}$ 里 के $\overline{\mathrm{N}}$ บ त 0 过 (1) 3 으 잉 क क 뭉 ब 0 ( (능 으 है 등 잉 은 क (ิ) ᄃำ (c) 그 을 (c) 픙 응 을 웡 잉 (1) 心 ᄃㄴำ ข $\stackrel{1}{ \pm}$ 으 约 인 응 흐은 월 ह क (1) क 등

(1) 므 으

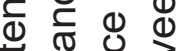
(d) 늠 क क बै क

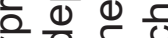
흥만 $\stackrel{0}{ \pm} 0$. $\subseteq \mp \dot{\overrightarrow{3}}$ மㅇㅇㅇㅇㅇ ल प $\overline{0}$ 웅 원휴 ㄱำ $N$ 응 i는 


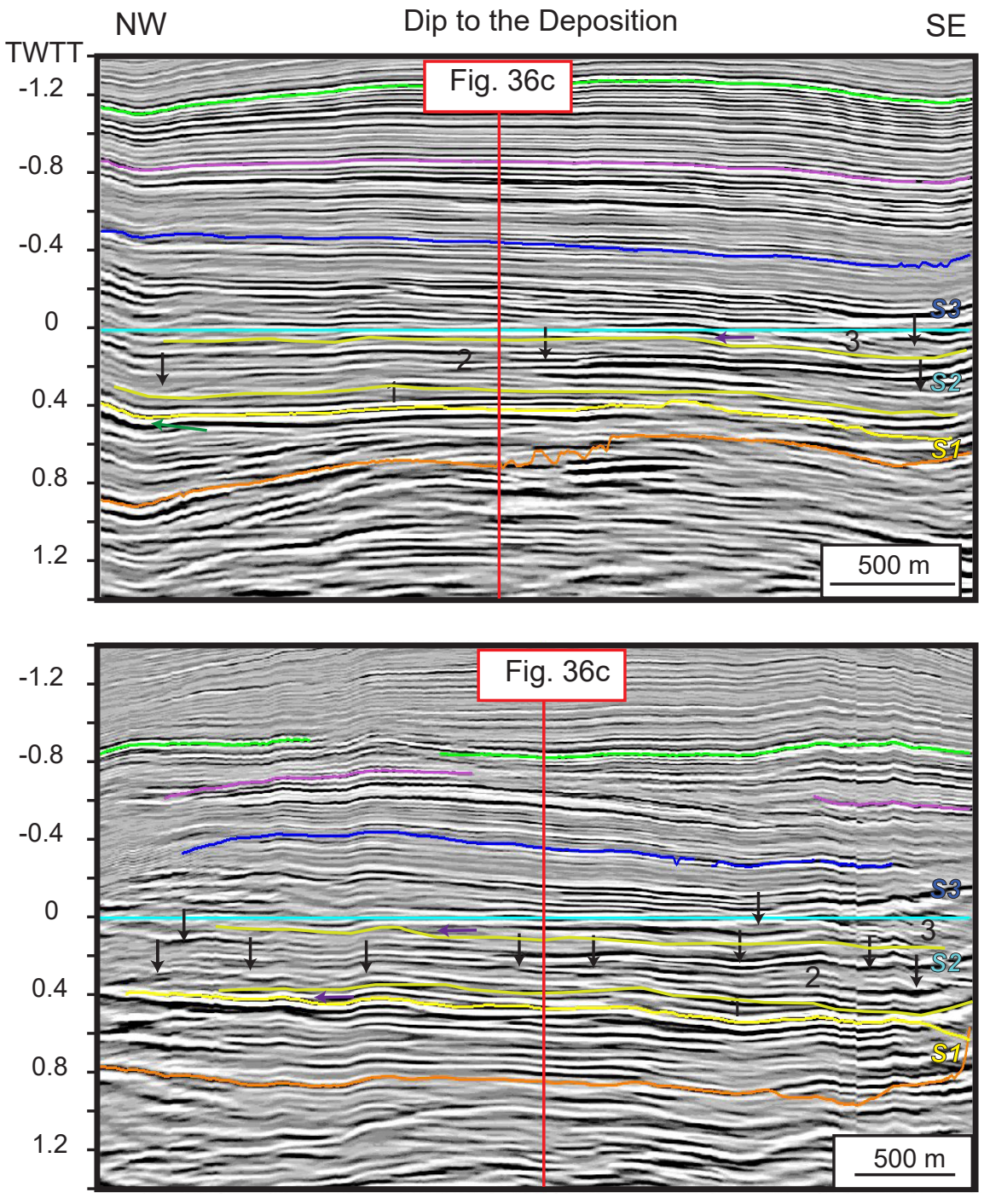

(a)

$\ddot{n}$

m

ज ल

ஸ)

인

응 으

$N \subseteq$

ه

ฮิ ठิ

등

Ф

을

응

(b) 过

(1)

능

$+\therefore$

등

응

$m$

心 음

ᄃ 정

i $\frac{1}{1}$

d 흔

응

으로

을

है

(1)

心 ర

రํํ

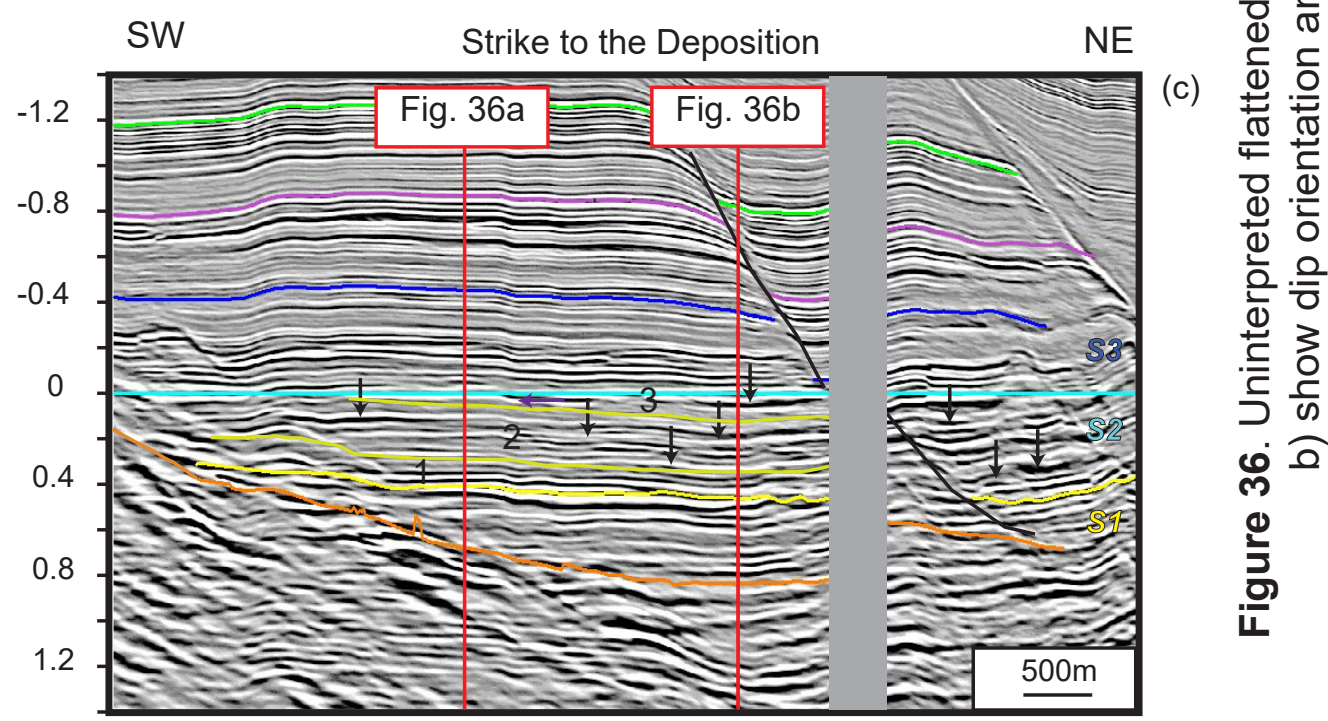




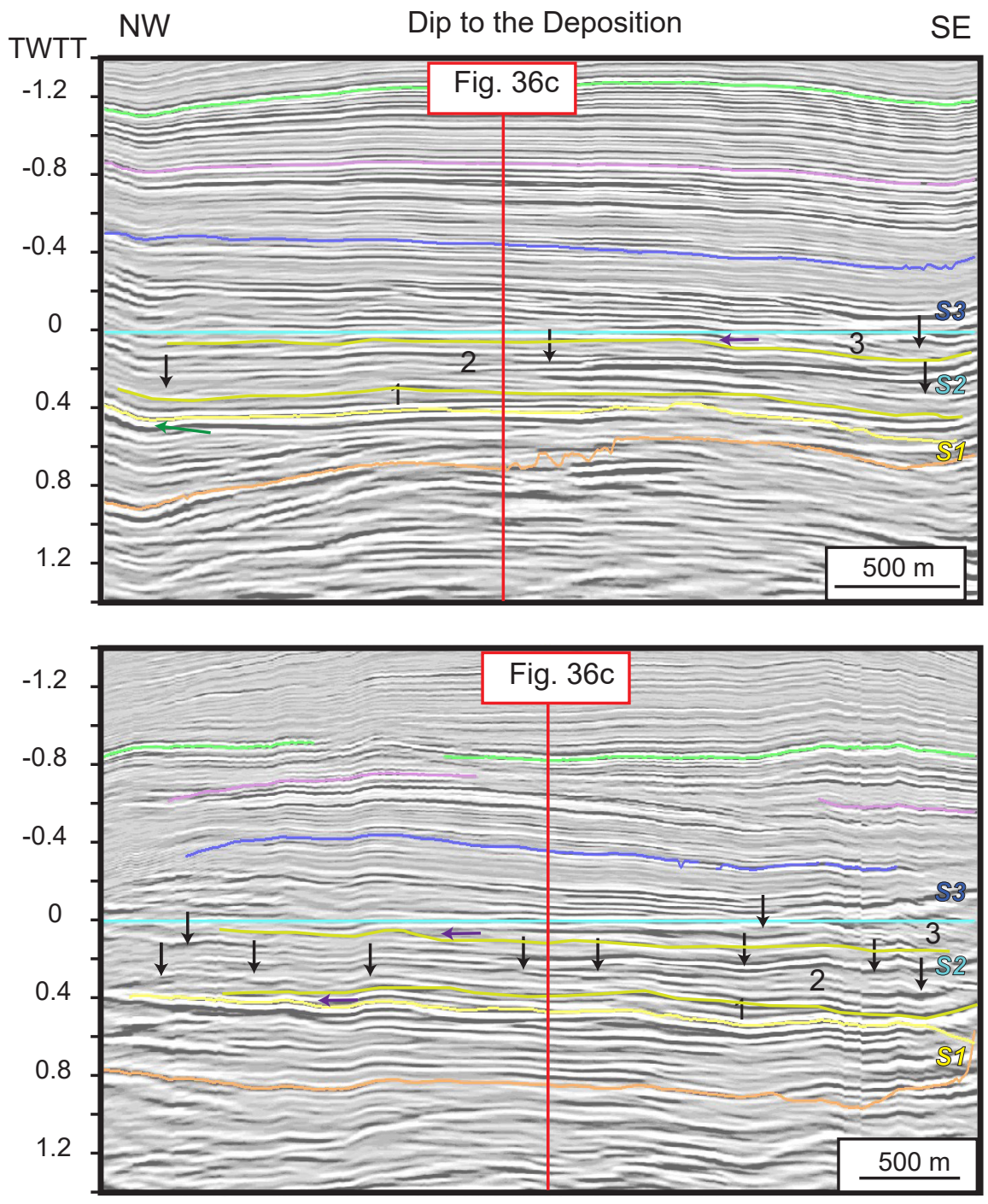

(a)

응

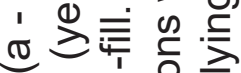
$\therefore \sim \frac{1}{1}$ 을 즌 ஸे

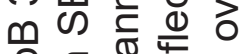
윽 등 뜬 는 の

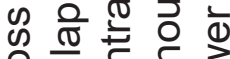
윤 됭 引 ช 0 등

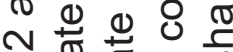

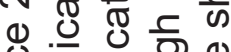
음 음 을 光 어 $\sum^{n}$ 응 (b) ๗ 은 은 엉. రำ 衣 Nㅡㄴ - $\frac{1}{3}$ 넌 은 은 진 ज $\mathrm{n}$ 它 (1) 을 을 듬 뜨 뜬 ㄷํ웡 으 응을 듬

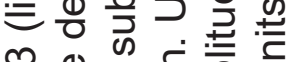
ตㅃㄷ도을 ज झ ज ᄃ이일 ○ 이 凹 d) 은 인 응 Ð ᄃ 드 을

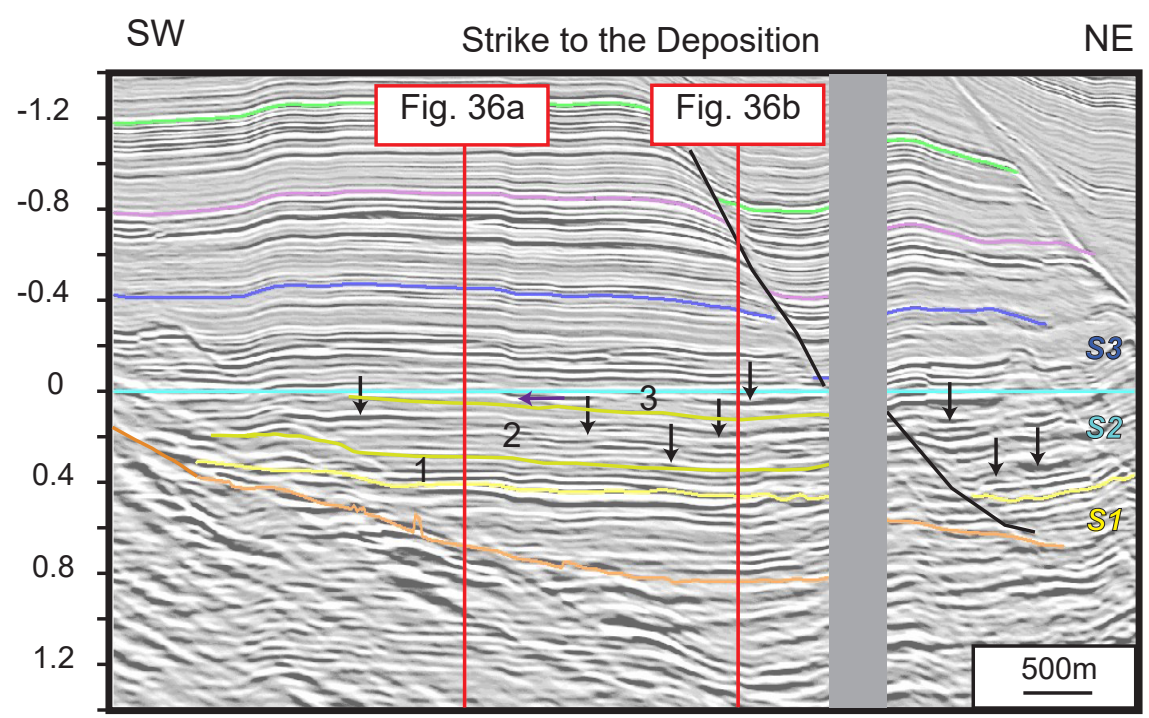
(c) $\frac{\omega}{d}$ के बे ஸ ब ब ल

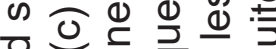

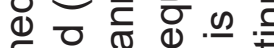

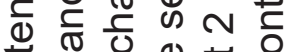

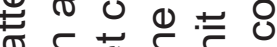
뜬 호워

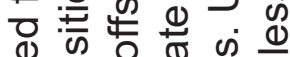
世 은 엉 으음

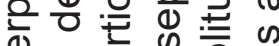
过 凹 d 드 동 올 을

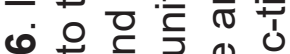

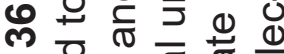
() ฮ ত 는 它 ह 원

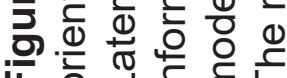




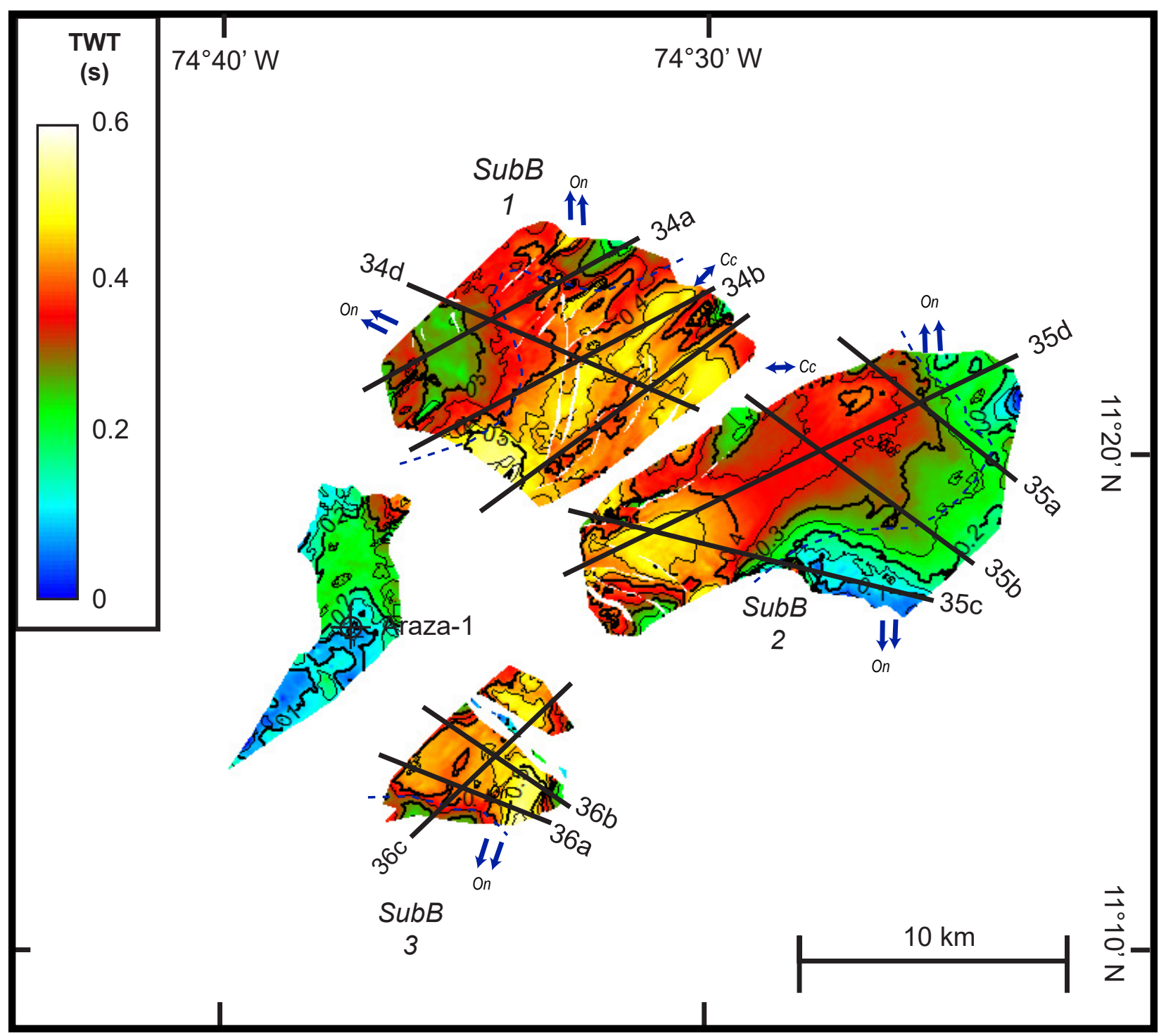

Figure 37. Isochron map of Sequence 2. Warm colors indicate thicker areas. Contour interval is 0.05 seconds (TWTT). Blue arrows indicate onlap direction. Dashed lines show transition from concordand to onlapping reflections. On: Onlap Cc: Concordant 


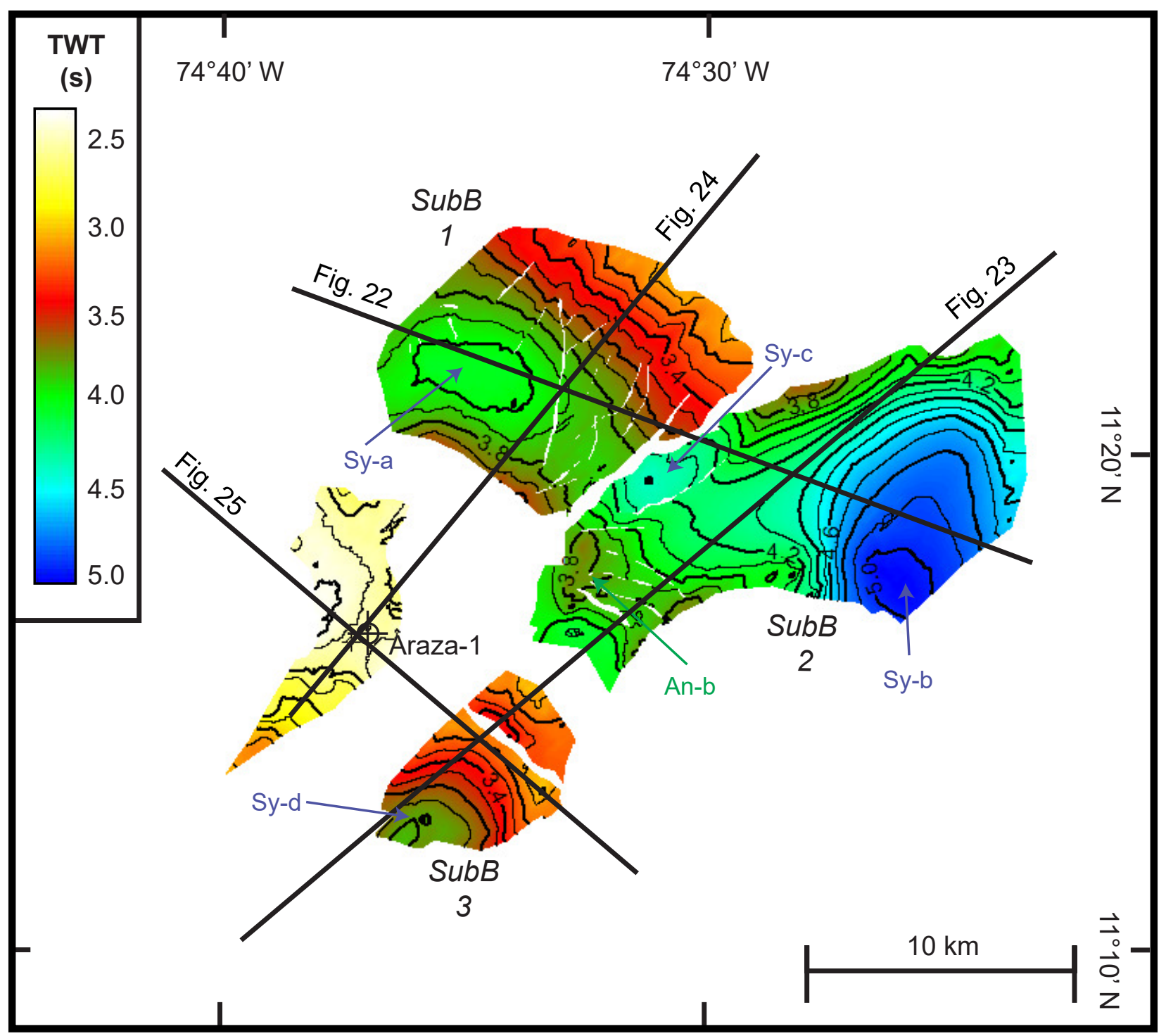

Figure 38. Time structure map at top of Interval 2 (SB3). Warm colors indicate structural highs and cool colors lows areas. Contour interval 0.1 seconds (TWTT). Anticlines $(A n)$ and Synclines (Sy) are labeled. 


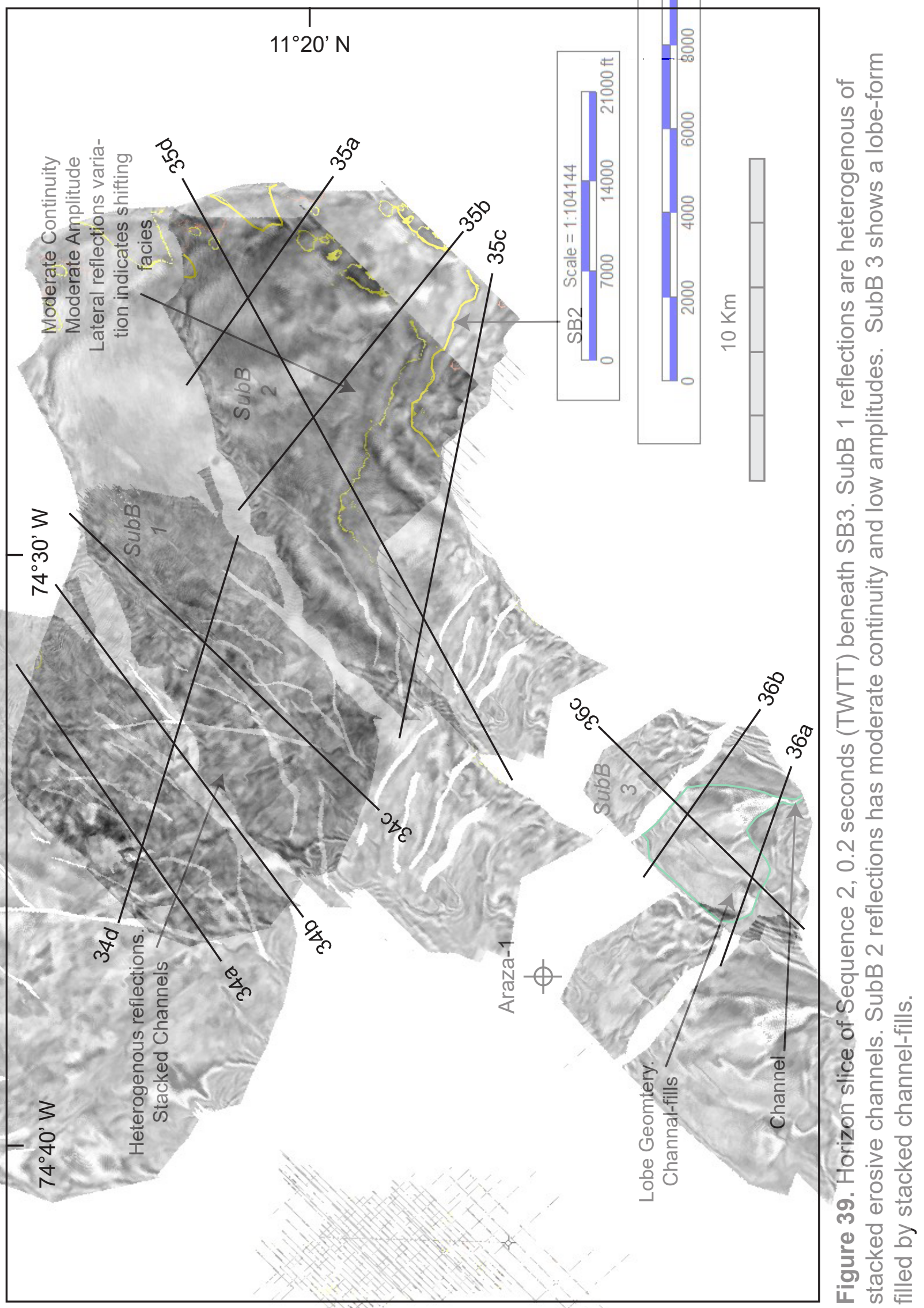


up to 0.2 seconds. This heavily channelized unit with this prominent erosion indicates extensive sediment bypass and fill.

In sub-basin 2, less confined sediments fill sequence 2 along the area. Semi-parallel reflections indicate channel-levee complex, stacked vertically along sequence 2 (Figure 35). The reflections onlap to the south, indicating a subtle paleo-topography high of sequence 1.

Sub-basin 3 has similar facies patterns to sub-basin 2 . The three units represent the changing location of the sediment into the basin.

\section{Sequence 3}

Key Surfaces

In sub-basin 1, the sequence onlaps SB3 to the north-west. To the SE, the reflections are concordant with SB3 (Figures 40, 43).

In sub-basin 2, the reflections onlap SB3 to the east (Figures 41, 43). In the easterncentral part of the sub-basin, where S3 is thicker (Figure 43), the reflections are concordant overlying SB3 (Figures 41, 43).

In sub-basin 3, the basal reflections are concordant in the center of the sub-basin. To the southeast, basal reflections onlap (Figures 42 - 43) onto SB1 and SB3.

In all three sub-basins, the reflections are concordant with the upper sequence boundary (SB4) (Figure 40 - 43). 


\section{$\underline{\text { Time-Structure Map }}$}

The upper sequence boundary (SB4) ranges from 2.3 to 4.8 seconds (TWTT) (Figure 44). In sub-basin 1, values range from 3.6 to 2.4 seconds (TWTT). The deepest part is in the western-central portion of the sub-basin, where a syncline trends east to southeast. The horizon shallows to the south onto a shoulder, and shallows gradually to northeasteast. In contrast to SB3, the trend of the synclinal axis has shifted slightly to the east (Figures 22, 25, 44).

In Sub-basin 2, SB4 ranges from 3.5 to 4.8 seconds (TWTT). A prominent N-trending syncline to the southeast. The deepest point is 4.8 seconds (TWTT) in the south-central part of the structure. The horizon shallows gradually to the north and west, culminating flattening to a northeast-trending shoulder in the west central area. The horizon is shallowest to the north and west (Figures 24, 44). Two structures with three-way closure are present against Fault $B$ to the north (An-a) and west (An-b) (Figures 23, 44). Between An-b and An-a, SB4 deepens among Fault B and a shear fault in the south (Figure 44), developing a partial syncline (Sy-c) cut by these two faults.

In Sub-basin 3, SB4 ranges from 2.8 to 3.4 seconds (TWTT). The surface dips gently to the southwest (Figures 25, 44). A syncline (Sy-d) is present to the southwest, reaching its deepest point (3.1 seconds) in the central western area of the structure (Figures 23, 44). A slight offset is present in SB4 across a northwest striking fault. The shallowest part of SB4 is in the Araza High, where it ranges from 3.0 to 2.3 seconds (TWTT), (Figures 24, 25). 


\section{Isochron Map}

Sequence 3 varies in time values from 0.1 to 0.7 seconds (TWTT) (Figure 43). In subbasin 1 , the sequence time-thickness values vary between 0.3 and 0.6 seconds (TWTT), where has its highest values to the south adjacent to Fault $B$. The iso-thick trends subparallel to the fault. A second iso-thick is in the central part of the sub-basin. It trends perpendicular to Fault $\mathrm{C}$. The sequence thins gradually to the northwest and northeast at both sides of the sub-basin (Figure 43).

In sub-basin 2, sequence 3 varies from 0.2 to 0.6 seconds (TWTT). The thickest part is in the western-central part of the basin. Sequence 3 thins gradually to the east and southwest. At the southwestern edge of the sub-basin, a local iso-thick is present adjacent to the major frontal normal fault (Figure 43).

In sub-basin 3, S3 varies from 0.2 to 0.6 seconds (TWTT). Two local iso-thicks are present in the sub-basin; a large one to the southwest adjacent to Fault $C$, and a shallower one to the northeast, adjacent to a smaller intra-basin fault (Figures 25, 43).

Sequence 3 is thinnest across the Araza High with values between 0.05 and 0.2 seconds (TWTT) (Figure 43).

\section{$\underline{\text { Seismic Facies (Internal Description) }}$}

In sub-basin 1, sequence 1 is characterized by prominent erosional surfaces, filled by fair continuous subparallel reflections. The reflections are offset vertically and horizontally along the sub-basin (Figure 40). The channel-fill geometries to the NW stack obliquely northwards, and the channels in the central area stack vertically. Lower amplitude reflections are present to the north underlying the stacked channels. The sequence 
onlaps both sides of the sub-basin (southwest and northeast). The horizon map at 0.1 seconds (TWTT) beneath SB3 shows heterogeneous facies pattern interpreted as stacked channel-fill. These geometries have subtle sinuosity and strike to the northwest (Figure 45). The deeper horizon map (0.2 seconds (TWTT) beneath SB3) shows more straight channels that trend northwest (Figure 46).

Three internal units (1-3) are present in sub-basin 2. In the western profile (Figure 41), S3 is thicker and displays fair continuous reflections throughout the internal units. In the eastern part (Figure 41), the sequence thins considerably and the units show better continuity. Unit 1 onlaps to the east and is dominated by moderate continuity reflections, interpreted as channel-levee complex. Unit 2 thins and onlaps to the southeast onto Unit 1. It is characterized by less-continuous reflections, primarly stacked channel-fill and levees to the northwest (Figure 41). Unit 3 onlaps to the northwest and shows stacking channel-fill geometries in the center part of sub-basin 2; good continuous reflections adjacent to the channel geometries are with good continuity. The horizon map shows channel facies that trend to the northeast across Unit 3 (Figure 45).

In sub-basin 3, two prominent units perform sequence 3. The lower unit (1) displays offset channel-fill sediments that migrate vertically to the south. Laterally continuous reflection geometries with good amplitude represent the levee deposits adjacent to the channels (Figure 42). Unit 1 onlaps onto SB3 to the north. Unit 2 is characterized by parallel reflections with good continually and with moderate amplitude. Unit 2 terminates to the south with TS1 and has been cut by a normal fault displacement. 


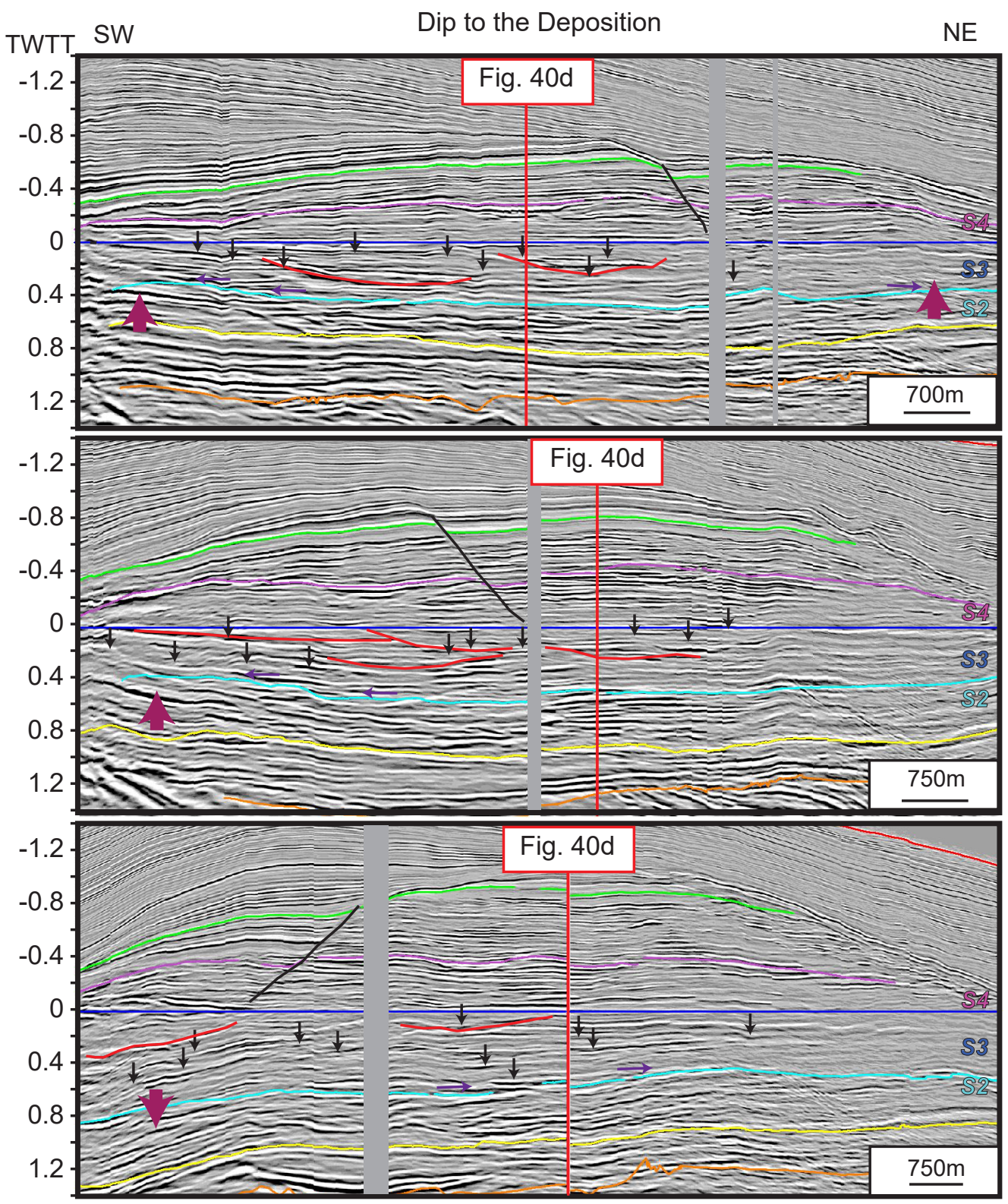

(a)

(b)

(c)

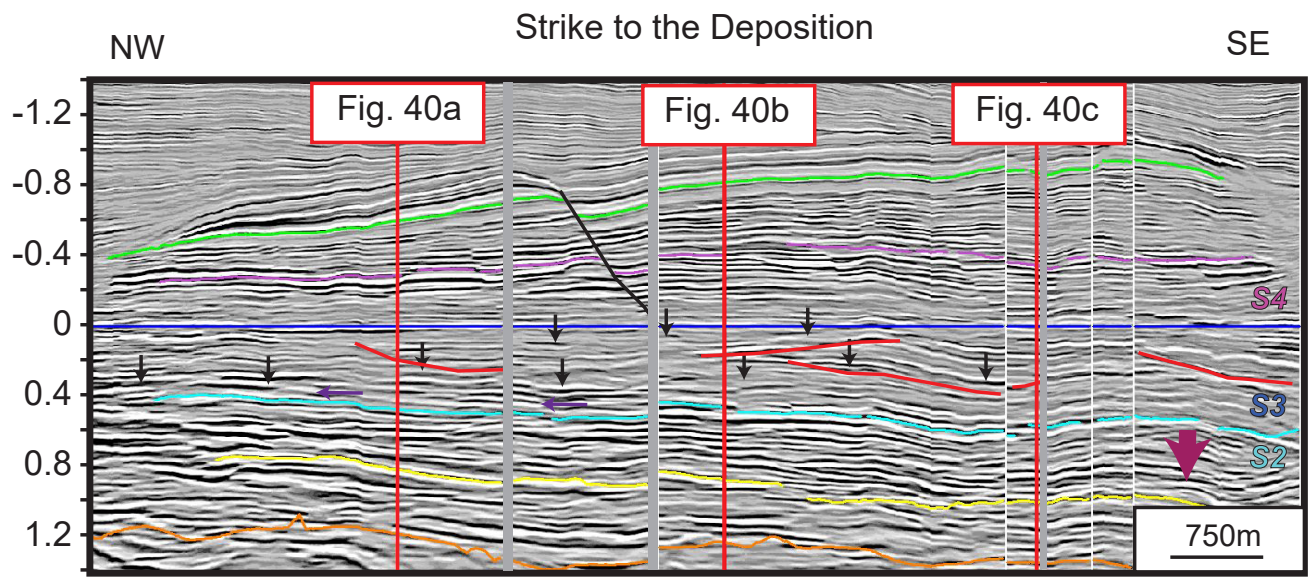

(d)

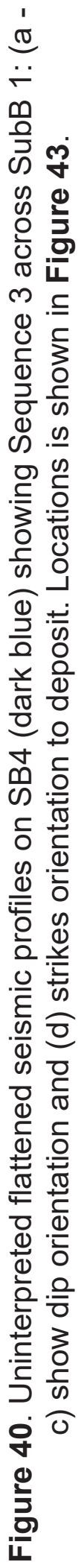




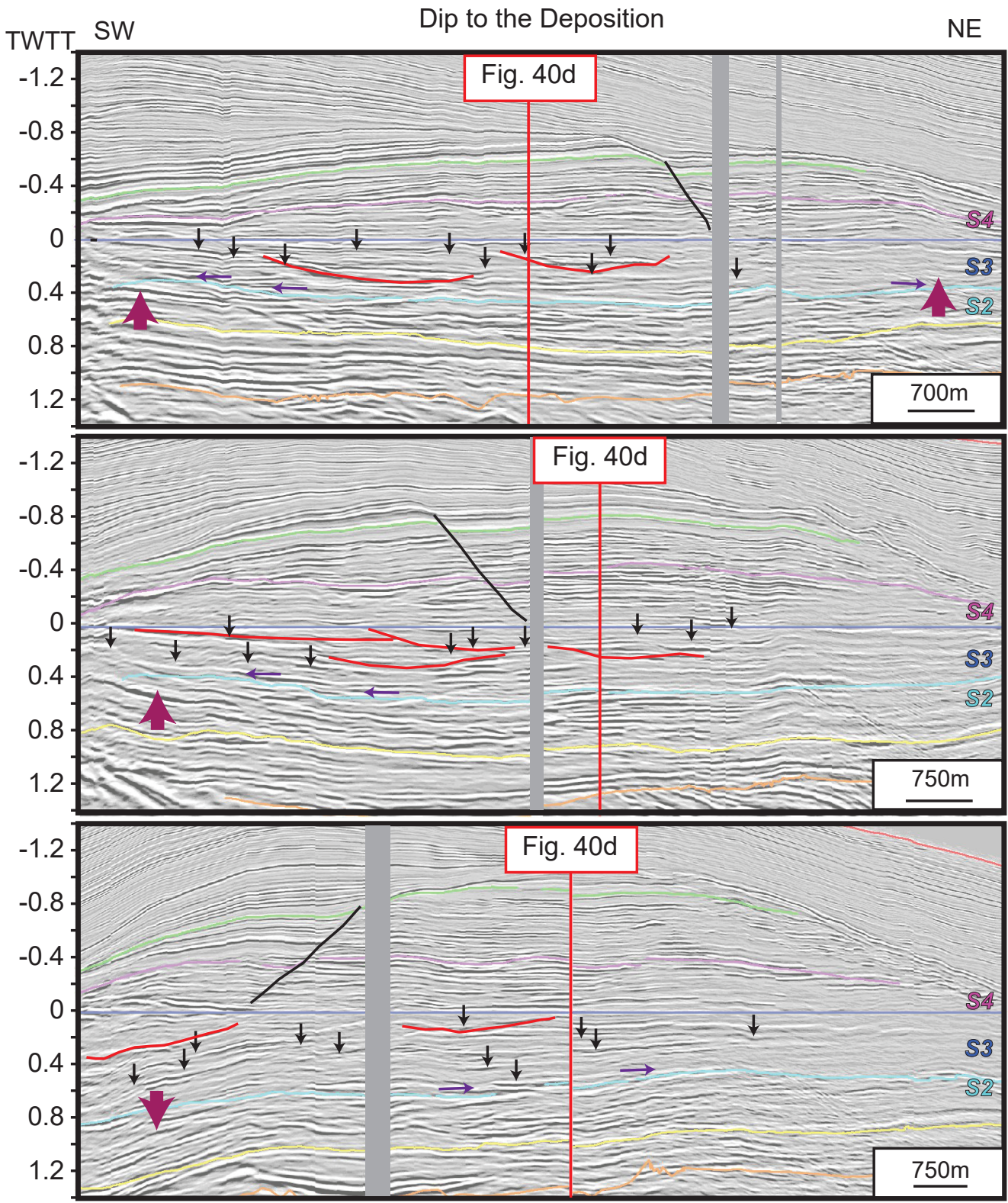

(a) 으

ชิㄷํㅇ

1 은 윤

$\ldots m$ ป

๗

윽 등 으

ज

( ) 응

ஸ ত ত

인 든

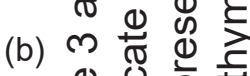

(ᄈ) 으 을

드은 응

(1)

כ थ $\frac{1}{\sigma}$

(1) 으 으

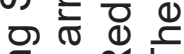

우

3은

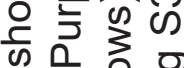

ฮิ 들 은 은

(c)

증 월워

ठ व

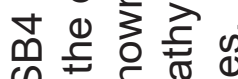

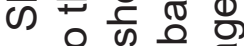

ᄃㄴำ

๘

(1) 등

范

응 능

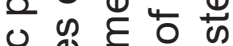

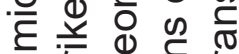

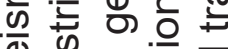

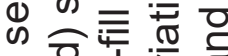

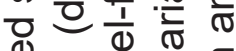

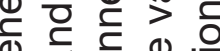

Strike to the Deposition SE

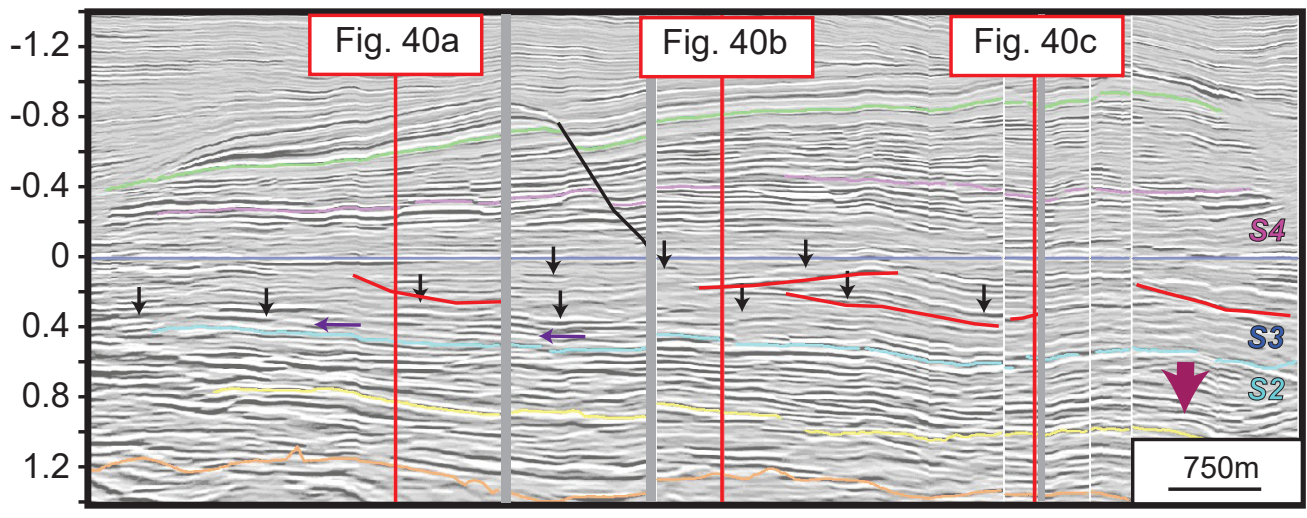

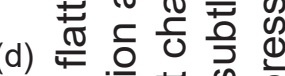

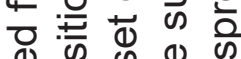

(1) ल

잉 잉

은 힝는

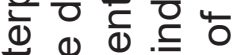

드

¿은 ह

ช ত 는

는 芒花

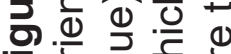

은 긍 든 

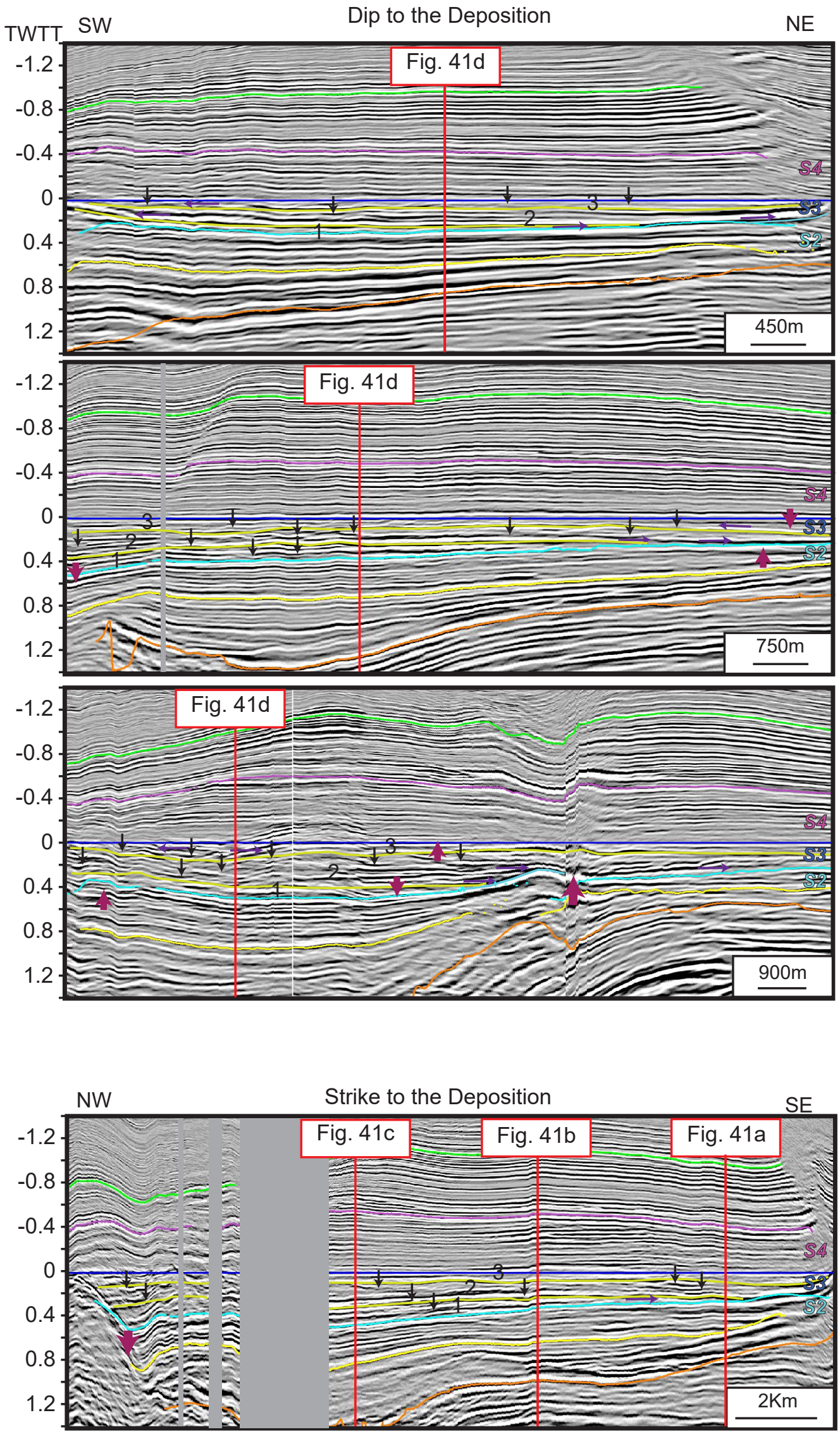

(a) 0

(1)

iv

$m$

을

ल

ํㅡㄴ

니음

$m$.

(1)

(b) $\frac{0}{\Phi}$

亏 ल

$\infty$.

을

돌 으

3

ज

(ฮ)

르음

논 음

ত্

(c) $\stackrel{0}{0}$

๓ัธ

凹 을

등 끌

क)

흥

을

을

ह

क

क

흐

ฮ

范

$\rightleftarrows$

워

(d)

흔 음

힝

吉

.

$5 \frac{\varrho}{5}$

5

(1)

5

으 

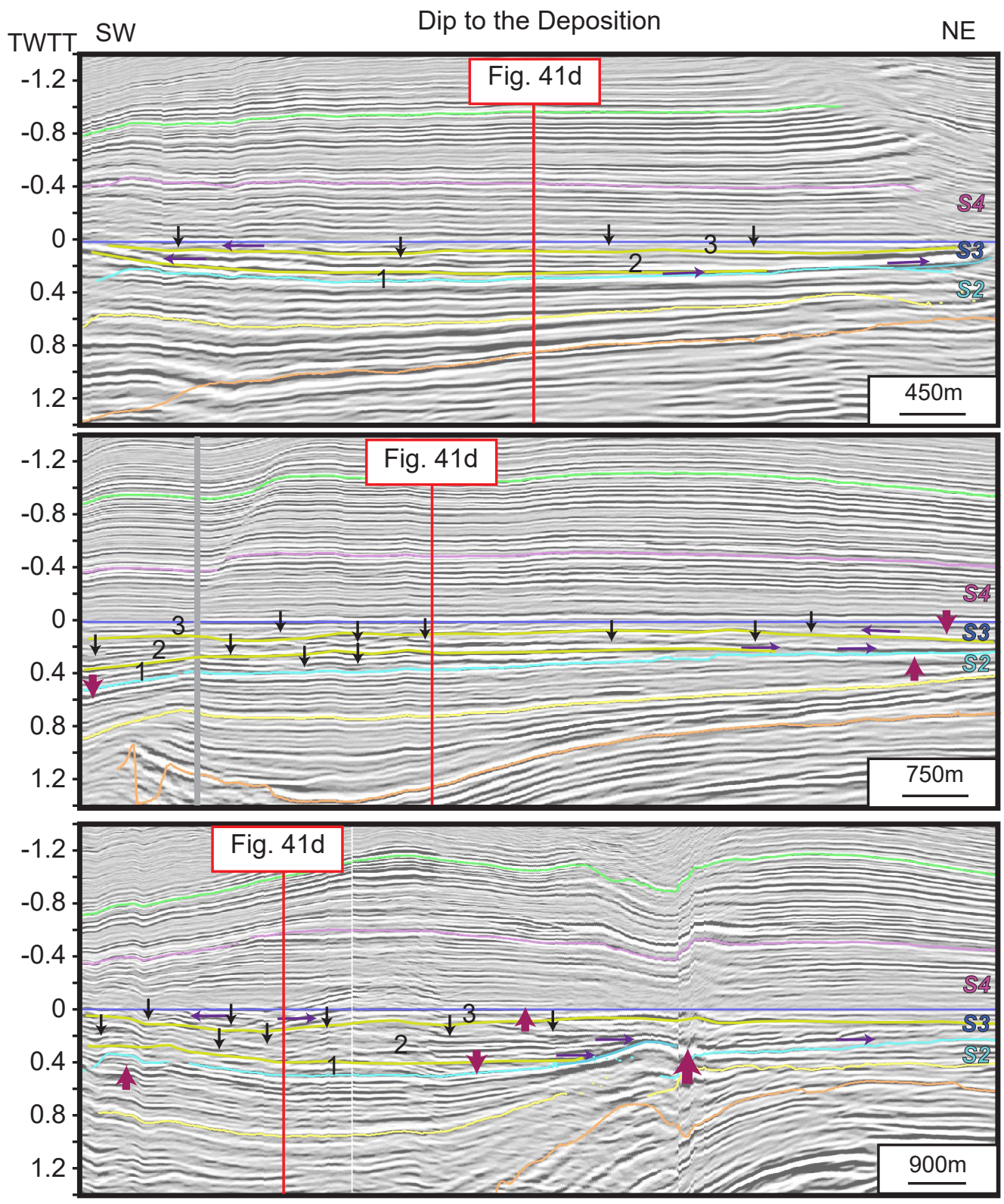

(c)

(a)

음 $\stackrel{9}{ \pm}$

0. $\quad 0 \stackrel{0}{0}$

(1) बิ

긍 등

$m$ 두 0

을 을 을 를

ल के

คิ ले ญ

บ ᄃ

(b)

(1) 용

당

ब( 0 응

워

雨

○ 흥

$\subseteq . \subseteq$

舟无

을

क 它远

(1)

긍 응 흥

는 등

뮤

잉잉

흘 으 잉

宓:

の

등 웡 ญ

क ठ ह

电 足

은은 은

a c 을

을

की

(⿻上丨

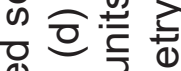

Ф들

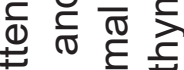

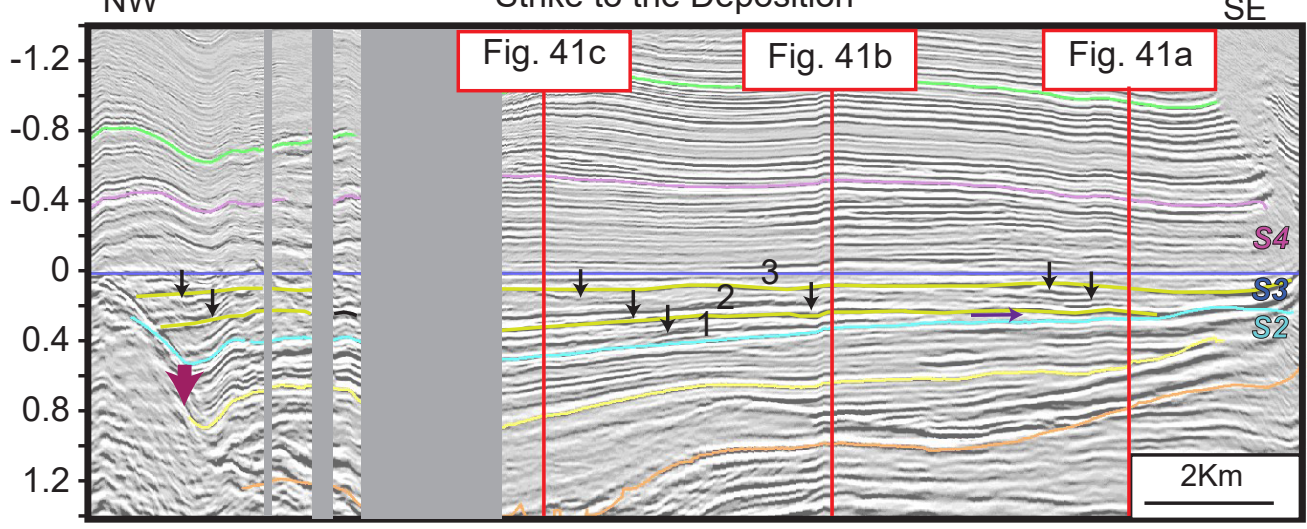

(d)

它 드

음

$\pm 00$

닝 웡 윤

은흉드는

(1) 0 (1)

도 $\cong$

$\therefore 000$

寸

() \ $\geq 0$

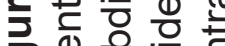

으론 윽 음 



(b)

일

क พ

잉

ত্

$m$ 는

ญ.

오

항

क ल

음요

放

ज त

(1)오

그음

능

증

한우

の

등 꿍

क

논

응 1

으놓

을

क 0

め 으

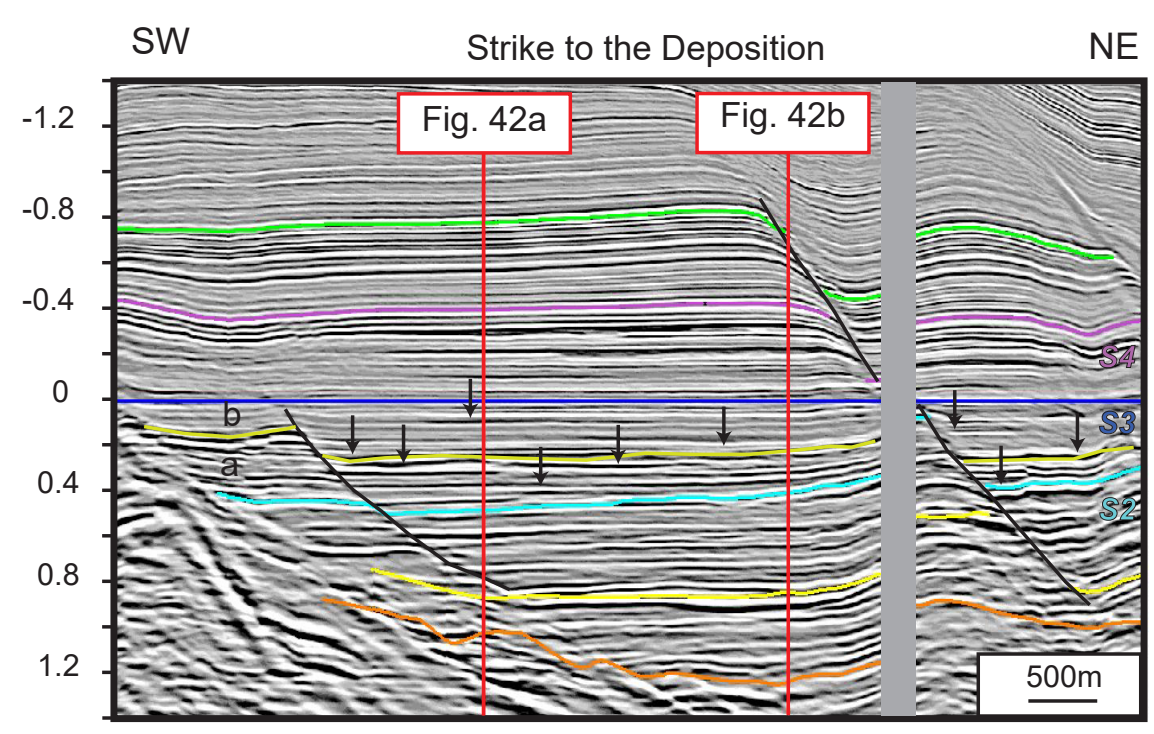

(c)

지

¿

(ब)

준

음

$\Phi$

닌으

은 음

ब

.⿳㇒口⿱上

$\supset$

ชั่ 

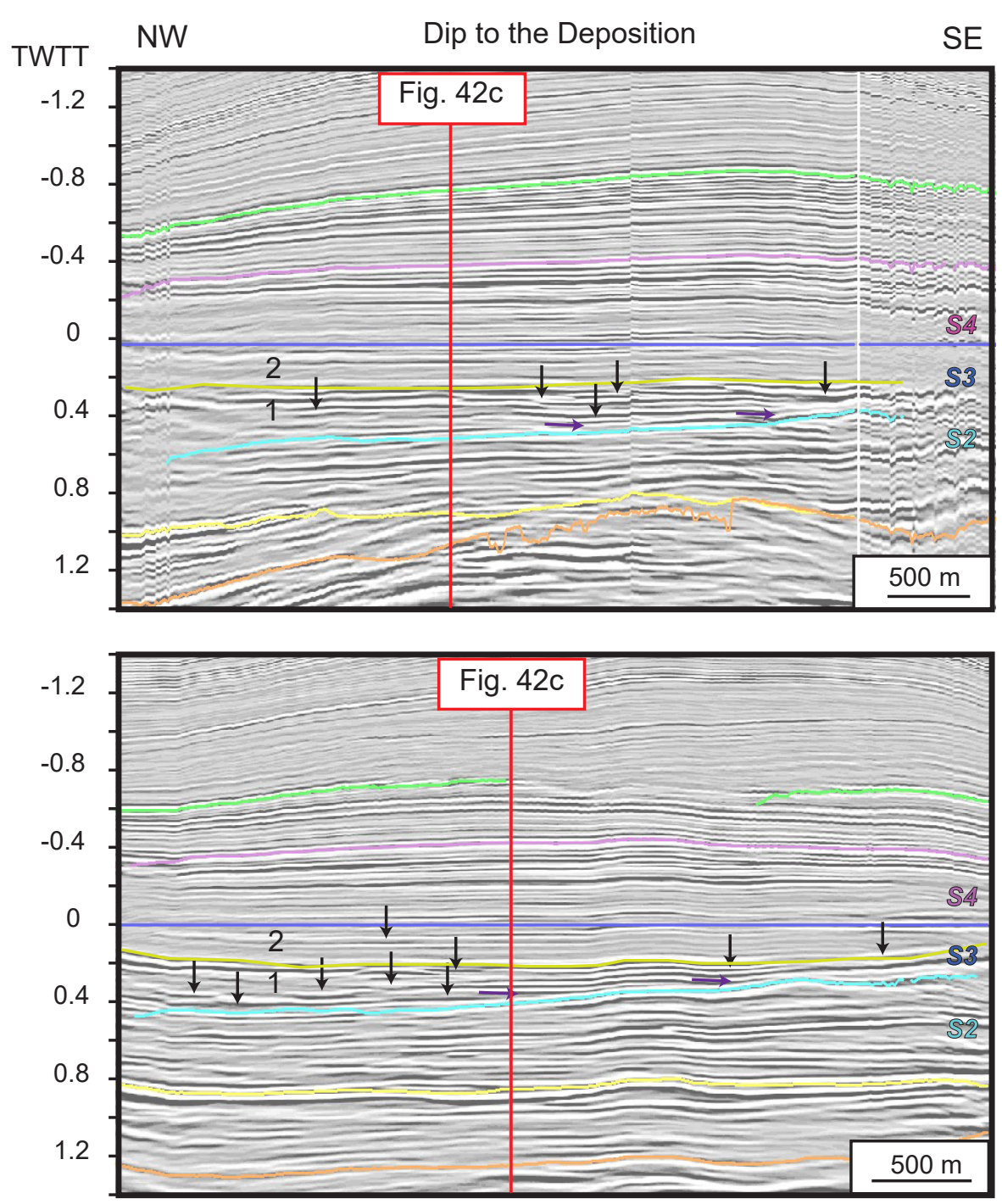

(b)

(a)

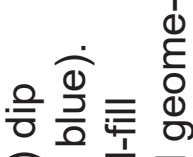

0

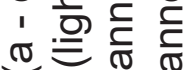

$\ddot{m} \frac{c}{0} \frac{c}{0}$

ल क क थ

윽 등을 엄

の ๗

की 응 잉

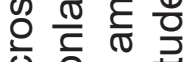

రั 0 도

$m$ 뜽을

ه 0 त

음 응.

(1) 언

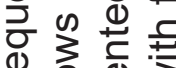

๗ 이 \

이 ㅎํ

잉ㅎㅇ응

3 인흔

क

(1)

긍 을 독 옹

늘

중 응 $\frac{5}{5}$

¿

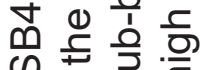

の के

ㄷํ워ำ

क ष

드요

응

잉

U \& $\frac{0}{0}$

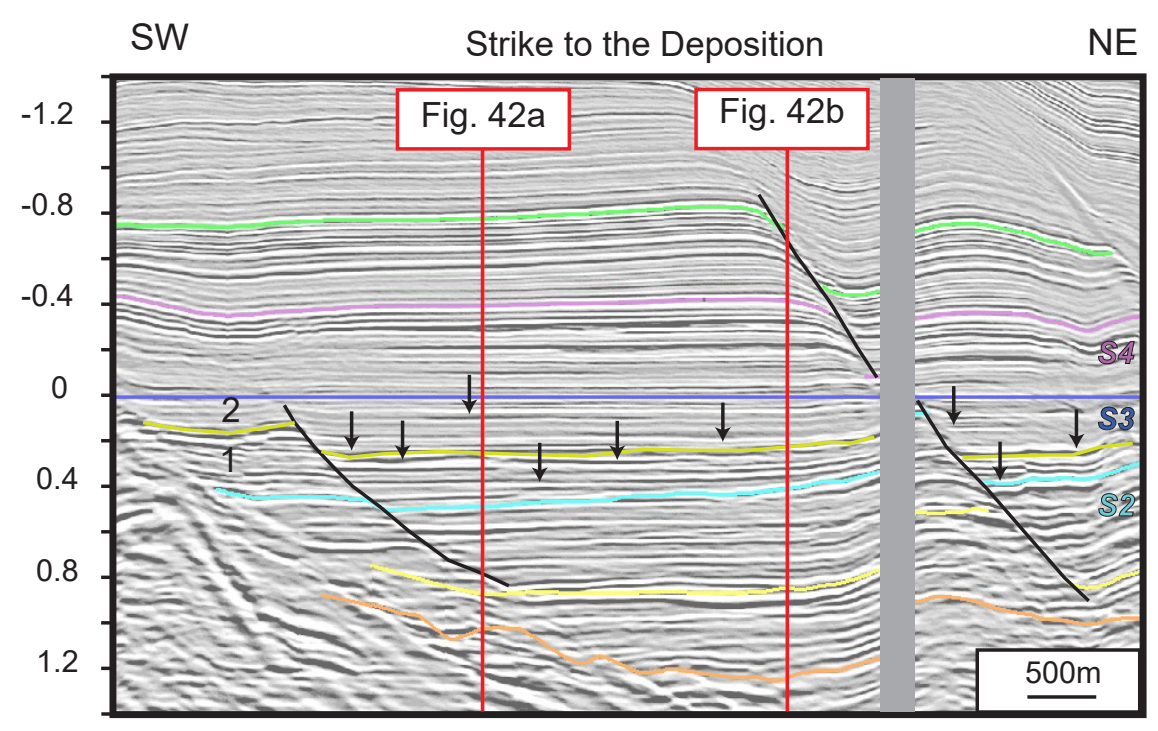

(c)

क 空 중

(ब) क 0

क Oิ N

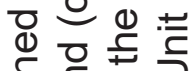

(ब)

范

뜬 은

웅 응

व) थ

흐웜농

(⿻)

등

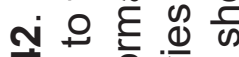

广 인인

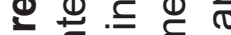

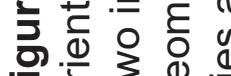

는 는 잉 


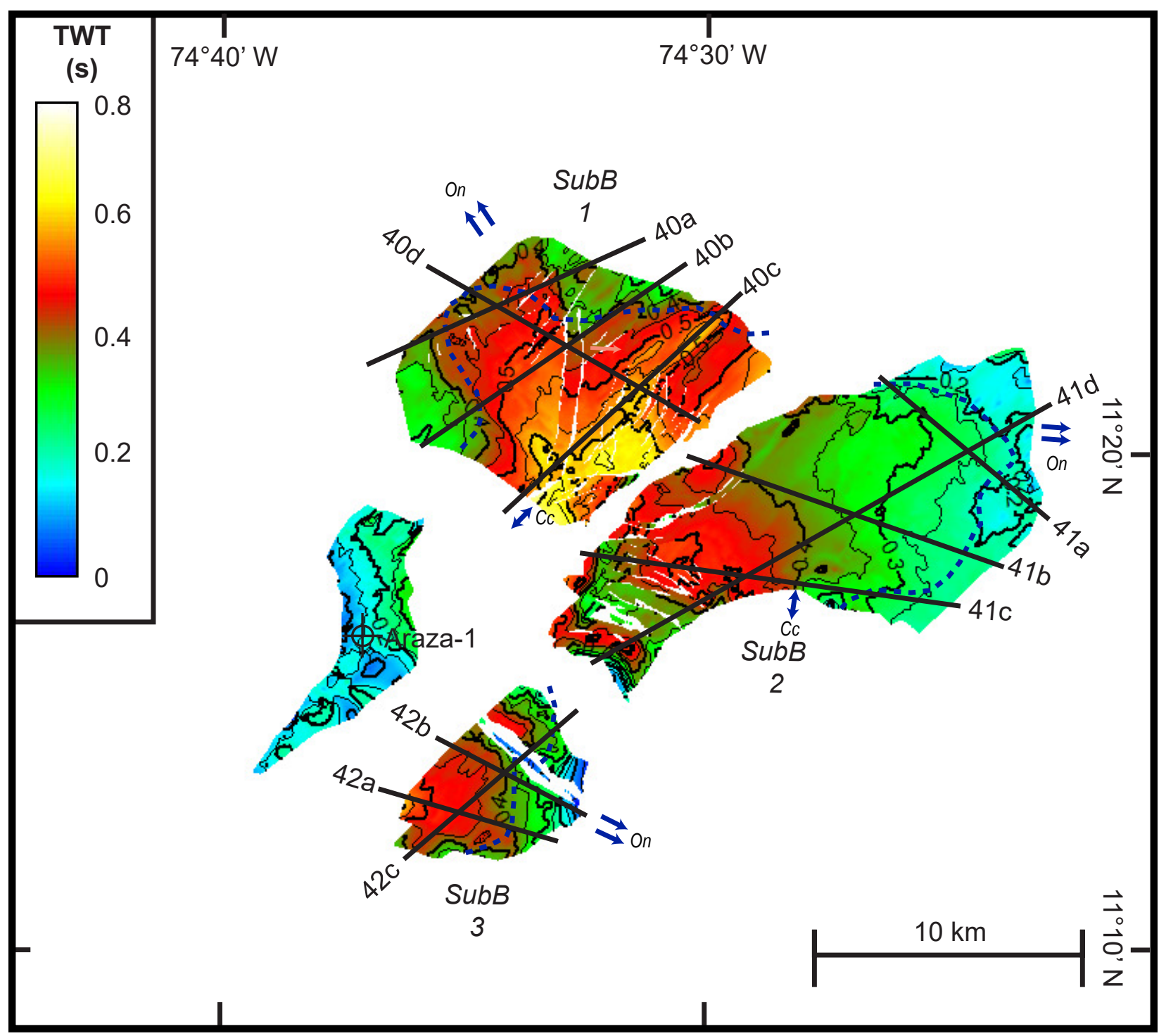

Figure 43. Isochron map of Sequence 3. Warm colors indicate thicker areas. Contour interval is 0.05 seconds (TWTT). Blue arrows indicate onlap direction. Dashed lines show transition from concordand to onlapping reflections. On: Onlap Cc: Concordant 


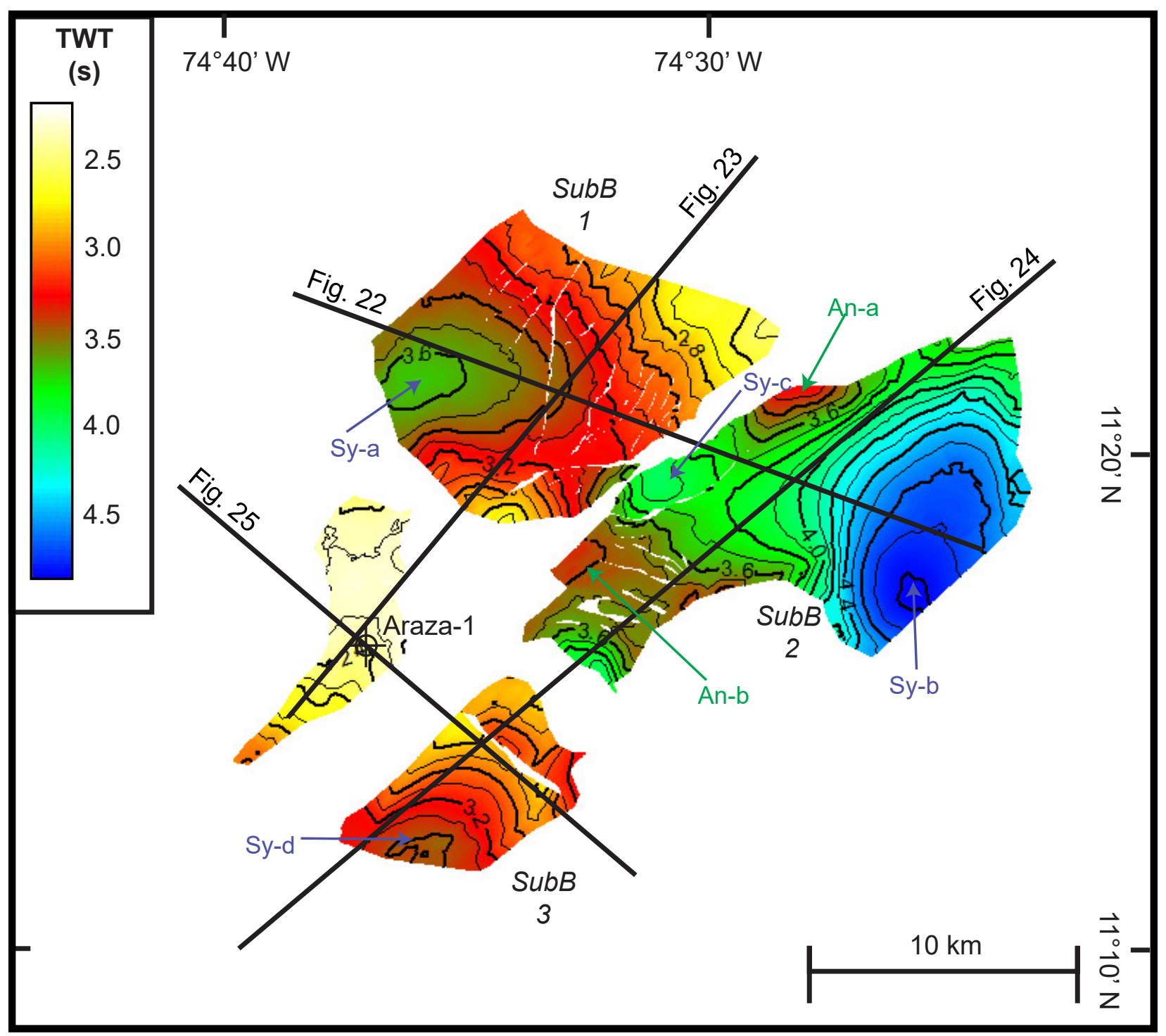

Figure 44. Time structure map at top of Sequence 3 (SB4). Warm colors indicate structural highs and cool colors lows areas. Contour interval 0.1 seconds (TWTT). Anticlines (An) and Synclines (Sy) are labeled. 


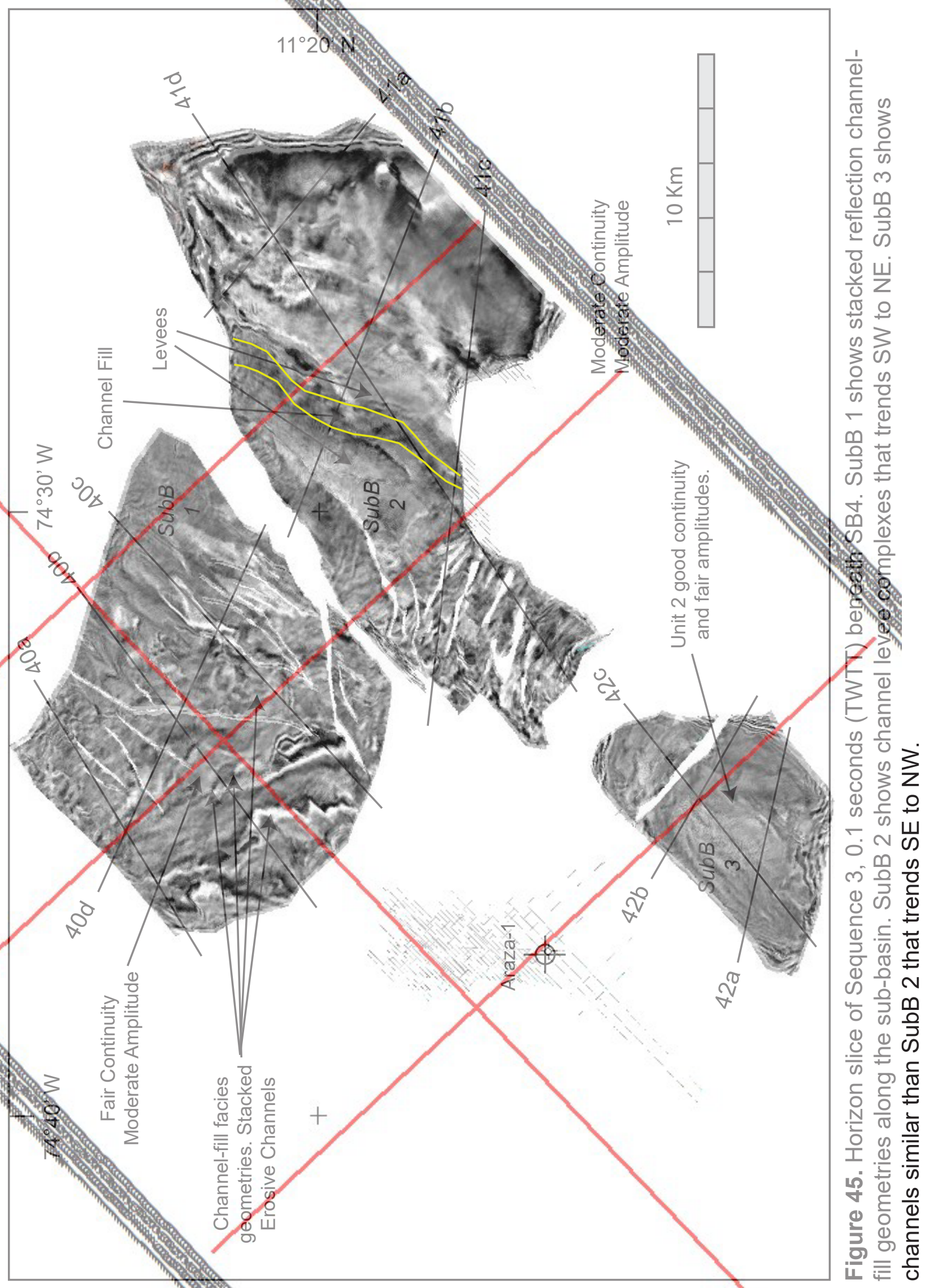




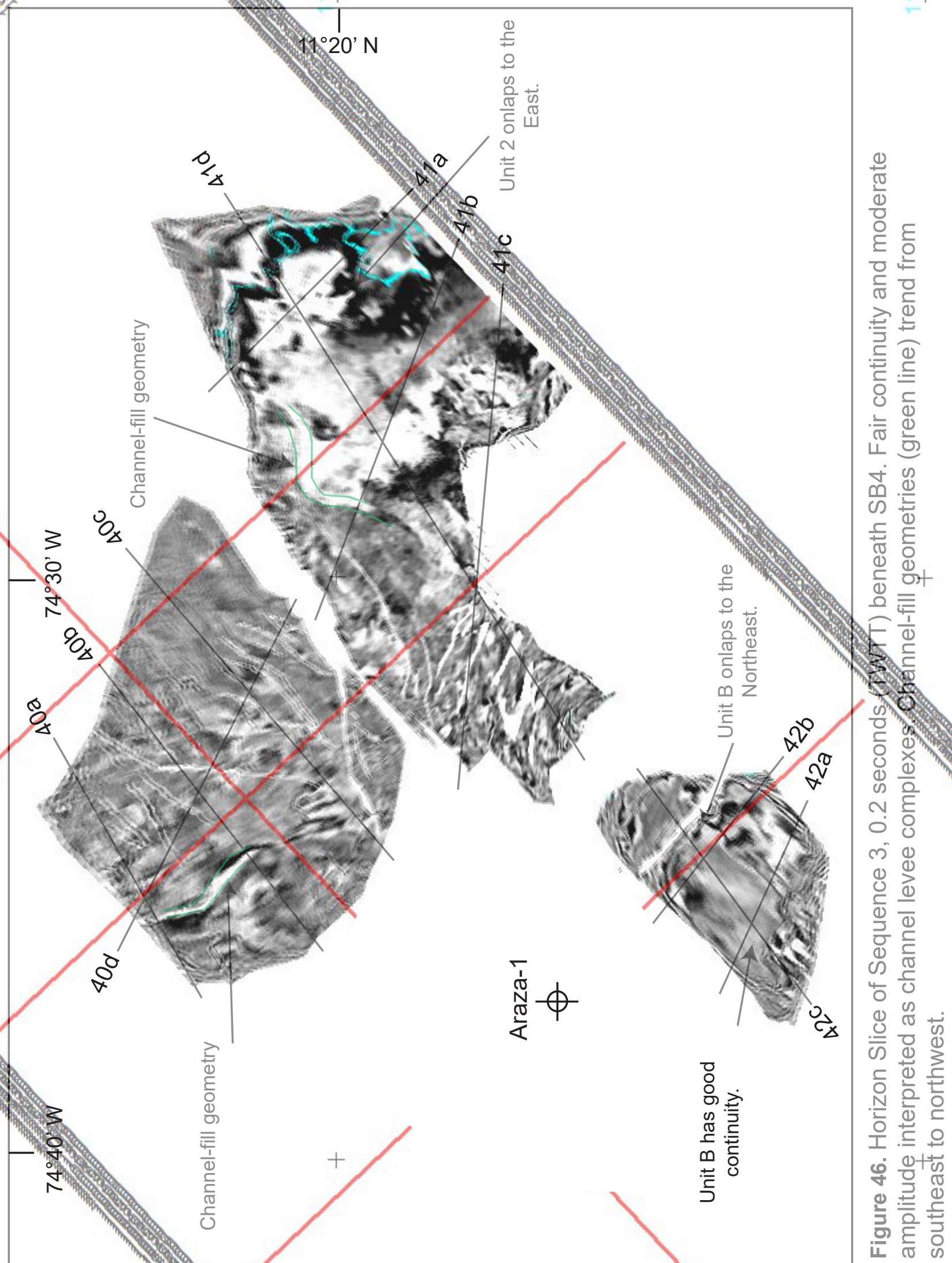




\section{$\underline{\text { Geologic Interpretation }}$}

In sub-basin 1, the prominent erosional surfaces filled by heavy channelized patterns are shown in Figures 43 and 44. The width of these erosional bowl-geometries are approximately $3 \mathrm{~km}$ and the time-thickness reaches 0.2 seconds. This heavily channelized unit with this prominent erosion indicates likely alternating sediments bypass and fill.

In sub-basin 2, the offset in the three units represent shifty areas of sediment input. Channel-levee systems are characteristic in these units. They offset laterally and vertically along sequence 3 .

In sub-basin 3, two distinguishable internal units are present in sequence 3. Unit 1 shows a channel-levee system characterized by continuous reflections that shift laterally and subtle wedges. These levee channels migrate obliquely to the southwest (Figure 42) and onlap onto SB3. Higher subsidence is present in the south-central part of Unit 1. Unit 2 has continuous reflections overlying Unit 1 interpreted as draped sediments that cover Unit 1. Uniform subsidence characterizes the shallower unit of the area.

\section{Sequence 4}

\section{$\underline{\text { Key Surfaces }}$}

Sequence 4 is bounded by SB4 at its base and SB5 at its top. In sub-basin 1, the basal reflections onlap onto flanks to the west and northwest (Figures 47,50 ). In the central part, reflections are concordant overlying SB4. 
In sub-basin 2, the basal reflections onlap onto SB4 to the north (Figures $\mathbf{4 8 , 5 0 )}$ and to the south. In the central part and eastern part of sub-basin 2, basal reflections are concordant overlying SB4 (Figure 53).

In sub-basin 3, the basal reflections onlap to the southeast onto SB1 (Figures 25, 49). In the central part, the basal reflections are concordant overlying SB4 (Figure 49).

For all of the sub-basins, the reflections are concordant at the upper boundary (Figures 47 - 49).

Time-Structure Map

Sequence boundary 5 (SB5) ranges from 1.6 to 4.3 seconds (TWTT) (Figure 51).

In sub-basin 1, SB5 ranges from 2.3 to 3.4 seconds (TWTT). In the north, a prominent syncline (Sy-a) that trends W-E reaches its deepest point (3.1 seconds). The structure dips gradually to the southeast and southwest of the sub-basin, reaching 2.4 seconds (TWTT) against Fault B (Figures 22, 25, 56). To the south-central, the horizon gradually dips against Fault B and reaches 3.3 seconds (TWTT) (Figure 51).

In sub-basin 2, SB5 ranges from 3.5 to 4.3 seconds (TWTT). The deepest point is to the southwest, where it reaches 4.3 seconds (TWTT) in the center of a prominent syncline $(\mathrm{Sy}-\mathrm{b})$ that trends $\mathrm{N} 10^{\circ} \mathrm{E}$. The sequence shallows gradually to the northwest in a threeway closure structure (An-b) and the west (An-a). The western structure (An-a) has in the central part a small deeper shoulder (Figures 22, 51). In the central northern part of the sub-basin, a partial syncline (Sy-c) structure is cut by Fault B and the south shear fault (Figures 22, 51). 
In sub-basin 3, SB5 ranges from 3.0 to 1.6 seconds. A prominent syncline (Sy-d) has the deepest point in the south-central part of the structure; SB5 shallows gradually to the south, reaching 1.6 seconds (TWTT) (Figures 25, 51). The structure has a slight offset in the northern part due to the normal major fault system.

The sequence is shallowest values in the Araza High, ranging from 2.5 to 2.0 seconds (TWTT) (Figures 24, 51).

Isochron Map

Sequence 4 varies in time values from 0.15 to 0.6 seconds (TWTT) (Figure 50). In subbasin 1 time values ranges from 0.15 to 0.5 seconds (TWTT). It is thickest to the centralsouth part of the sub-basin, where the iso-thick trends to the northeast. Two local thickness areas are present in the southern part adjacent to Fault B and the major normal northern faults (Figure 50). The sequence gradually thins to the northwest and the east (Figure 50). Sub-basin 2 ranges between 0.25 and 0.7 seconds (TWTT). The thickest point ( 0.7 seconds) is on the center east of the sub-basin. An iso-thick is present in to the central east of sub-basin 2. The sequence thins gradually to the north, east, and west. In the western part of the sub-basin, there is a locally thick area that trends parallel to the major frontal normal fault. In sub-basin 3 , the sequence varies from 0.35 to 0.5 seconds. The thickest point ( 0.6 seconds) is in the central-eastern part of the area (Figure 50). The sequence thins gradually to the western and eastern part of the sub-basin (Figures 25, 50).

\section{Seismic Facies (Internal Description)}

Two internal units (1-2) are described in sub-basin 1. Unit 1 has subparallel reflections with fair amplitude and continuity (Figure 47). The unit onlaps at both sides (southwest 
and northeast) of the sub-basin. In contrast, Unit 2 has upper part subparallel reflections with better continuity. Unit 2 onlaps to the southwest onto Unit 1 and shows stacked lens geometries vertically and erosional surfaces at the base of Unit 2 (Figure 47). Channellevee complexes are better developed in Unit 2.

The horizon map at 0.05 seconds (TWTT) beneath SB5 (Figure 52) displays wider channel-fill geometries that trend south to north. The higher continuous reflections adjacent to the channel-fills are the levee areas. The heterogeneous facies pattern indicates lateral channel migration in Unit 2. The horizon map at 0.2 seconds (TWTT) beneath SB5 shows less continuous reflections with less continuity (Figure 52). Subtle lateral phase shift is associated with central channel-fill geometries of channel-levee complex. These channels trend north-northwest in Unit 1 (Figure 53).

In sub-basin 2, two internal units (1-2) in sequence 4 are distinguishable. The lower unit (1) has low amplitudes, subparallel reflections with good continuity. In the central-western part of the sub-basin (Figure 48) the unit increases in thickness and decreases in the continuity of its reflections. It shows onlap onto SB4 in the southeast and northwest (Figure 48). Unit 2 has dominantly higher continuous subparallel reflections, compared with Unit 1. Likely, unconfined sediments fill the upper part of sub-basin 1, represented by channel-levee complexes. The unit onlaps onto Unit 2 to the north (Figures 48 ).

The horizon slice map at 0.05 and 0.1 seconds (TWTT) beneath SB5 (Figures 52 - 53) shows subtle lateral shifting reflections consist of stacked channel-levee complex. These maps extend across Unit 2 of the sub-basin. The 0.2 seconds horizon map (Figure 53) shows the onlap onto Unit 1 in the western part of the sub-basin. 


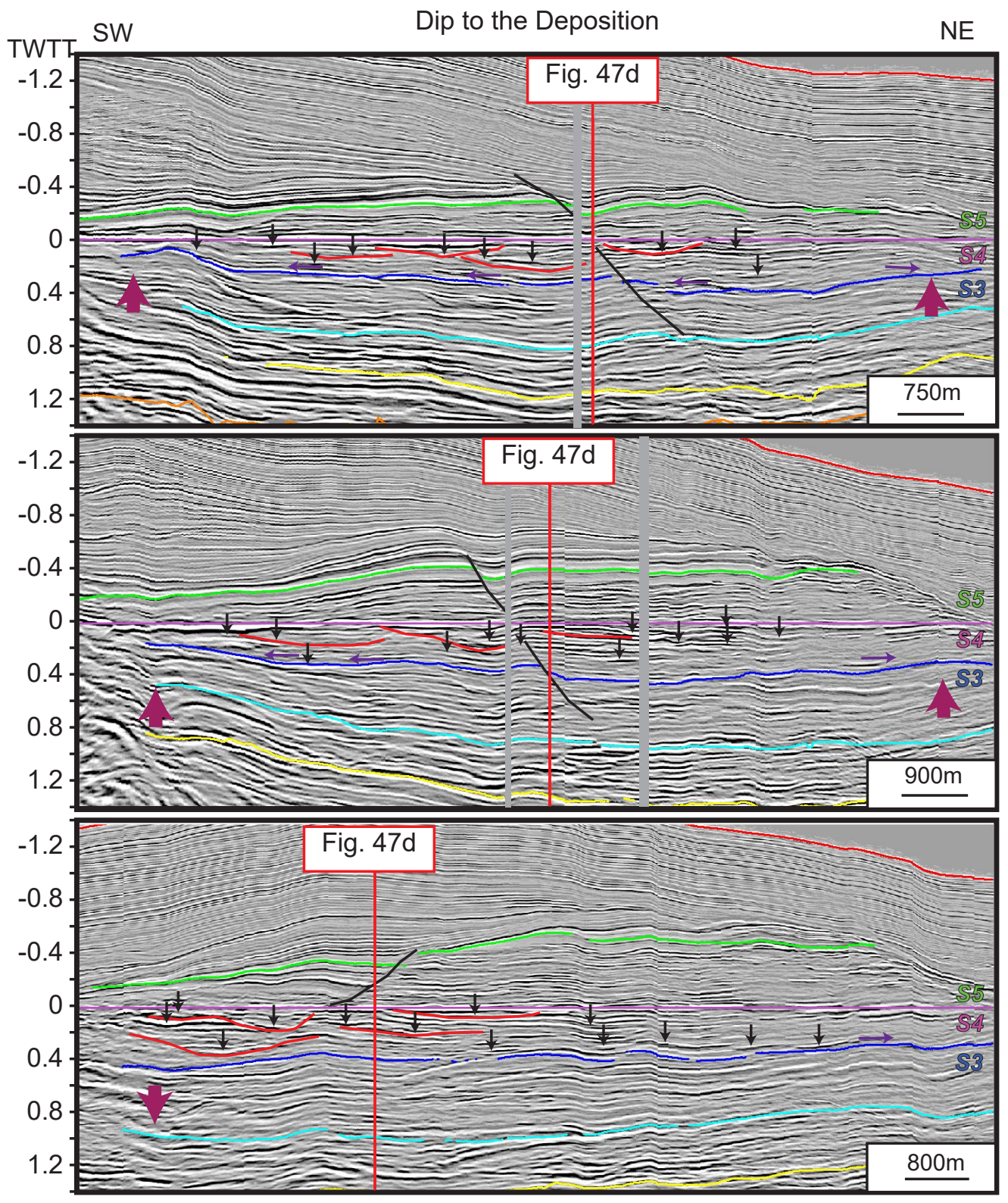

(a)

ช

(1)

$\ddot{r}$

으

ํㅡㄱ 우

क ํํㅇ

응 은

(b) $\forall .5$

บ)

बे

的

이. 또

ल क

이 음

政

응

क -

(1)

은 응

(c) 르

10 우

ณ

๘ 으

ธ

प) $\frac{\Gamma}{1}$

는

응

을 플

क ल

ब)

잉 듬

도

$\stackrel{\Phi}{ \pm}$

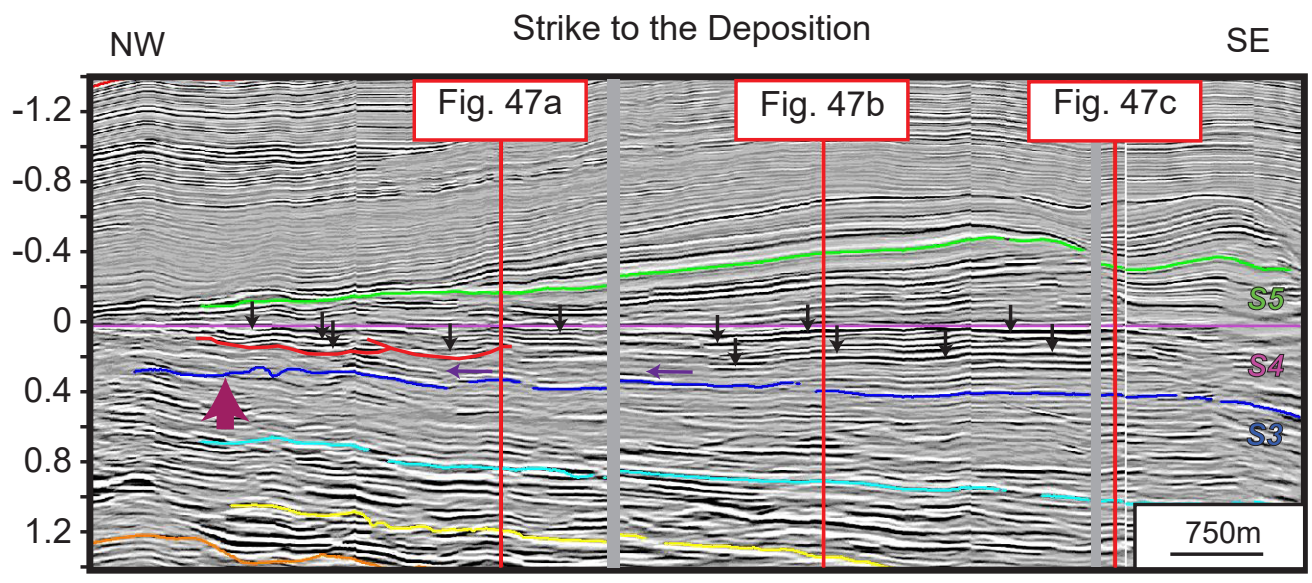

은

(d)

ข

은 응

힘

.

$\beth$

ร

ఏ

ำ

은 


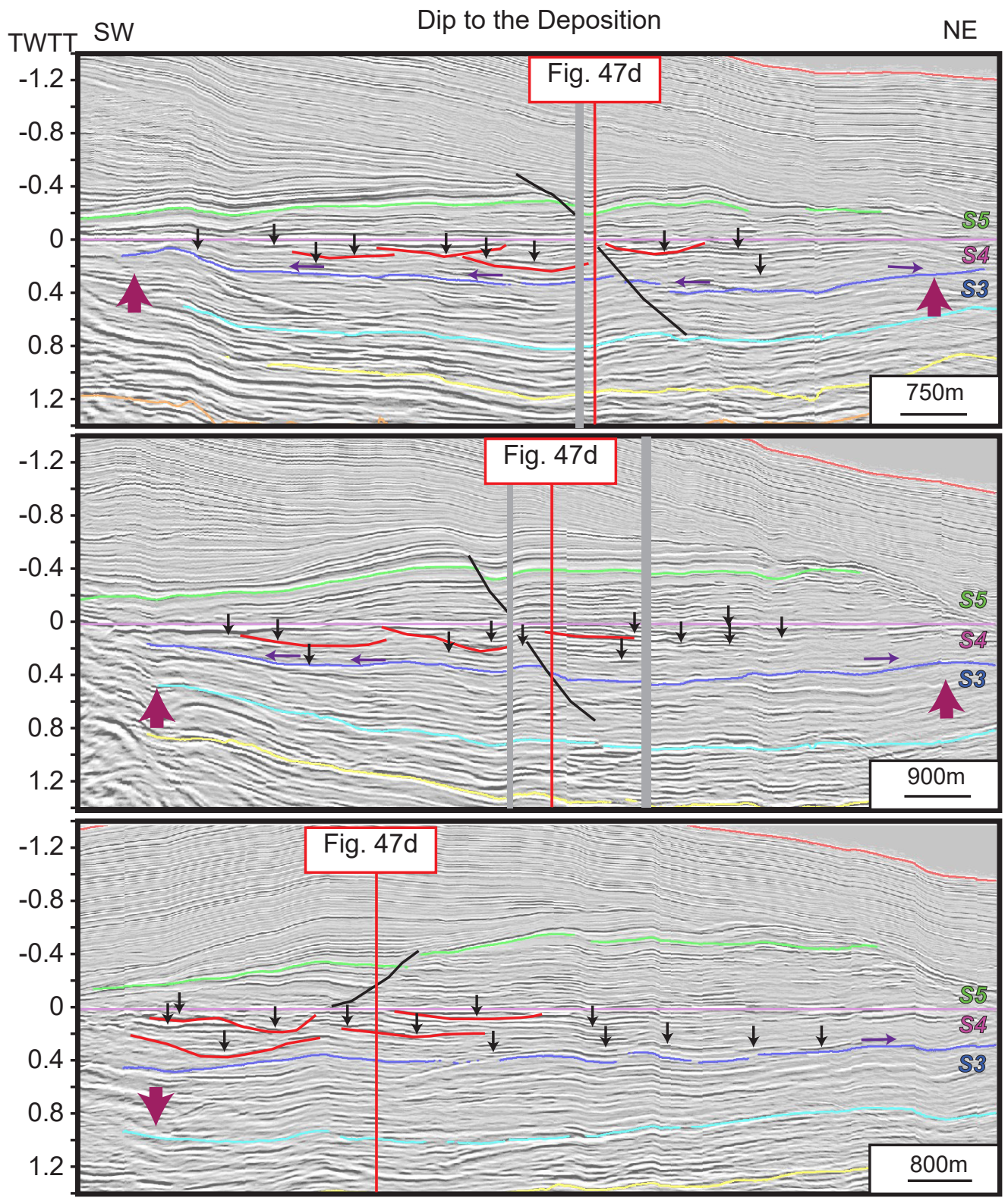

(a)

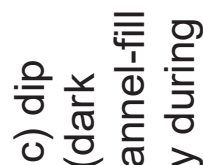

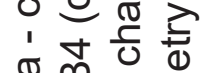
तथ ल ब है ᄃ 츠 ๑ वे 극 응

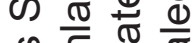

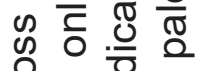
원 $\subseteq$ ๙ $\checkmark$ 访 ه.$\subseteq$ 은

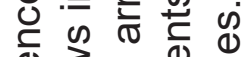

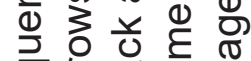
잉

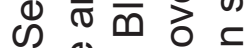
이으을 음 든 으을 을 क $\therefore$ के के (c) (ब) 음 원 응 ब

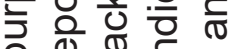
르웡 需 등

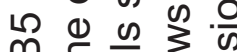
命 든 는 0 든

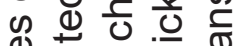
(1) 둔 은 응 类 을 \ ह 은 क क व के 心 $\mathrm{N}$. 이워

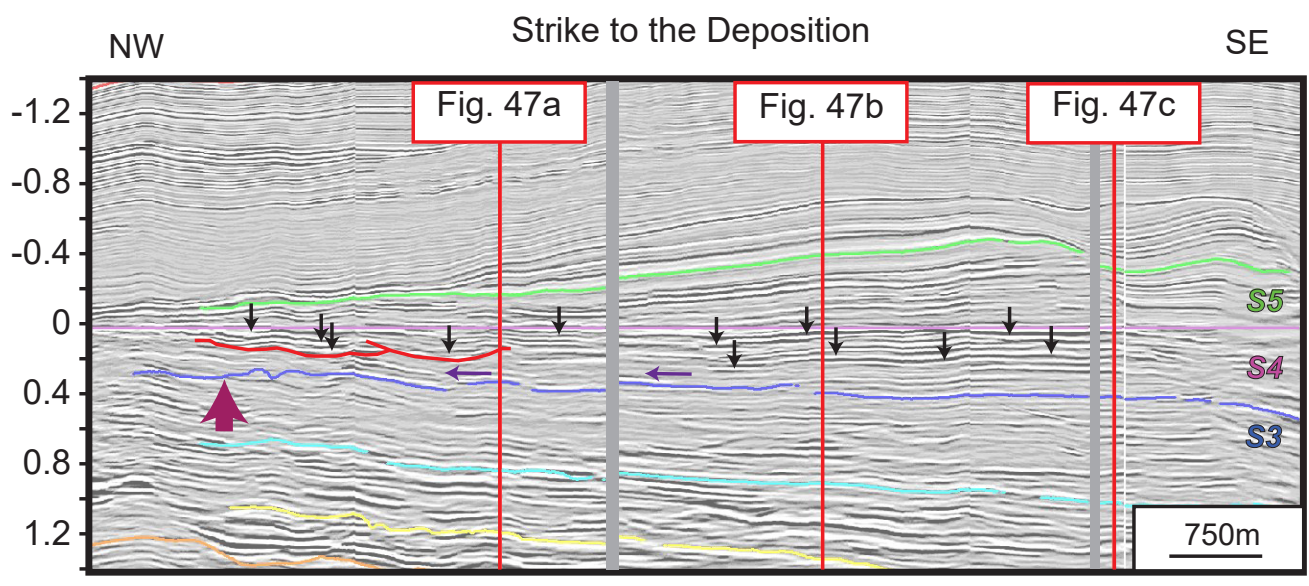

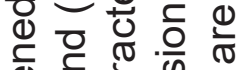

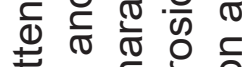
(d) 䒕 든 한

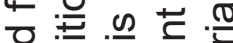
Q (1) 0 ग

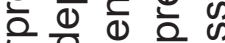
(1) 원 데 क क ㅏㅇ 누요도

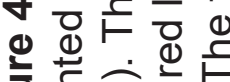
응 원 


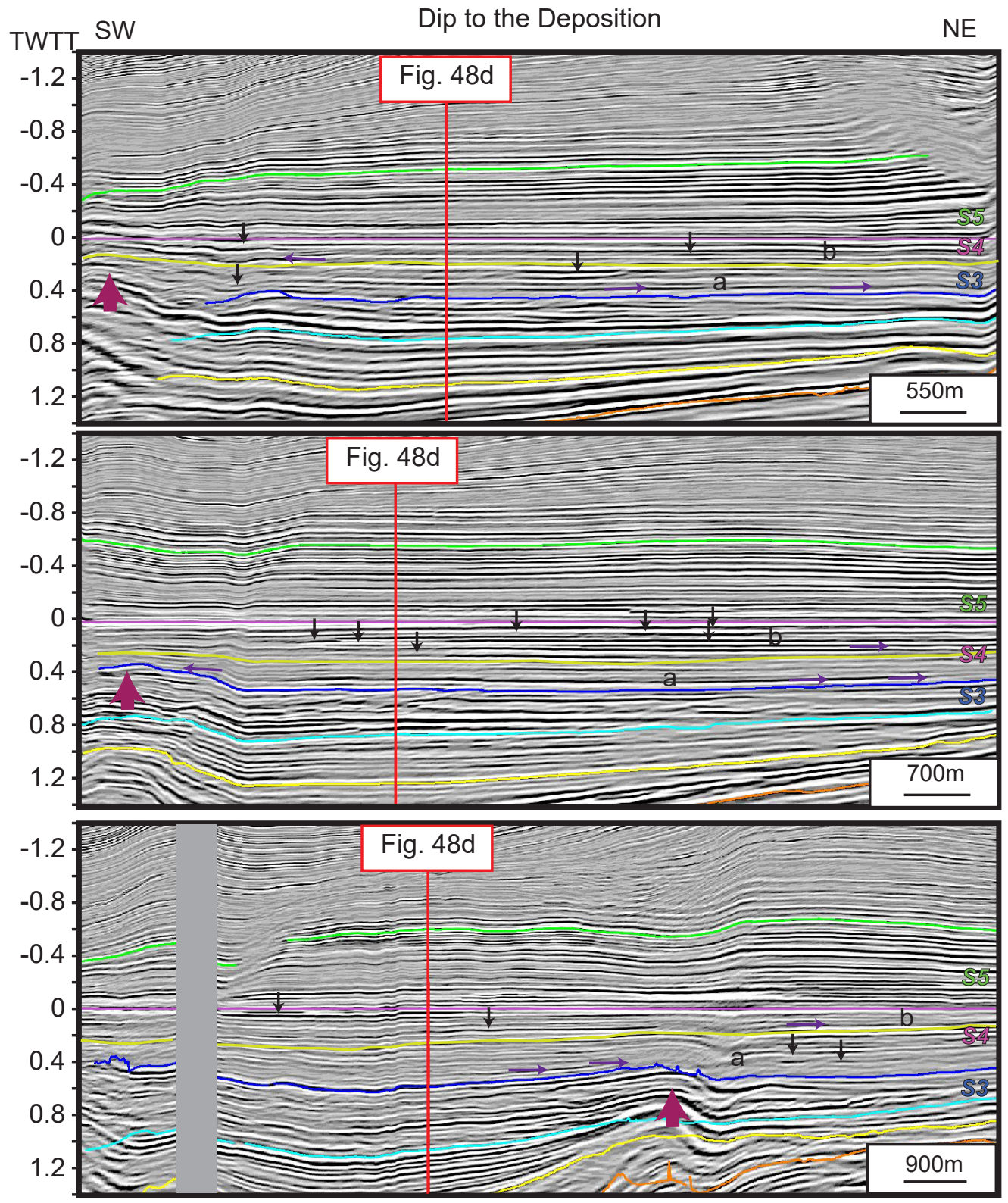

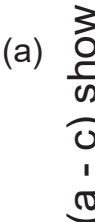

iv

m

극 유

(는

ल

닌 느

(b)

ธে

ष

บ

ఏ) 듬

ว

이료

ल थ

을으

文

응

ज -

(1)

은 응

(c) 르 $\frac{0}{0}$

요

동

듬

○ ్ㅠㅁ

(1)

产

흐워

으 픈

है

बे

응

ฮ

옳

푼 음

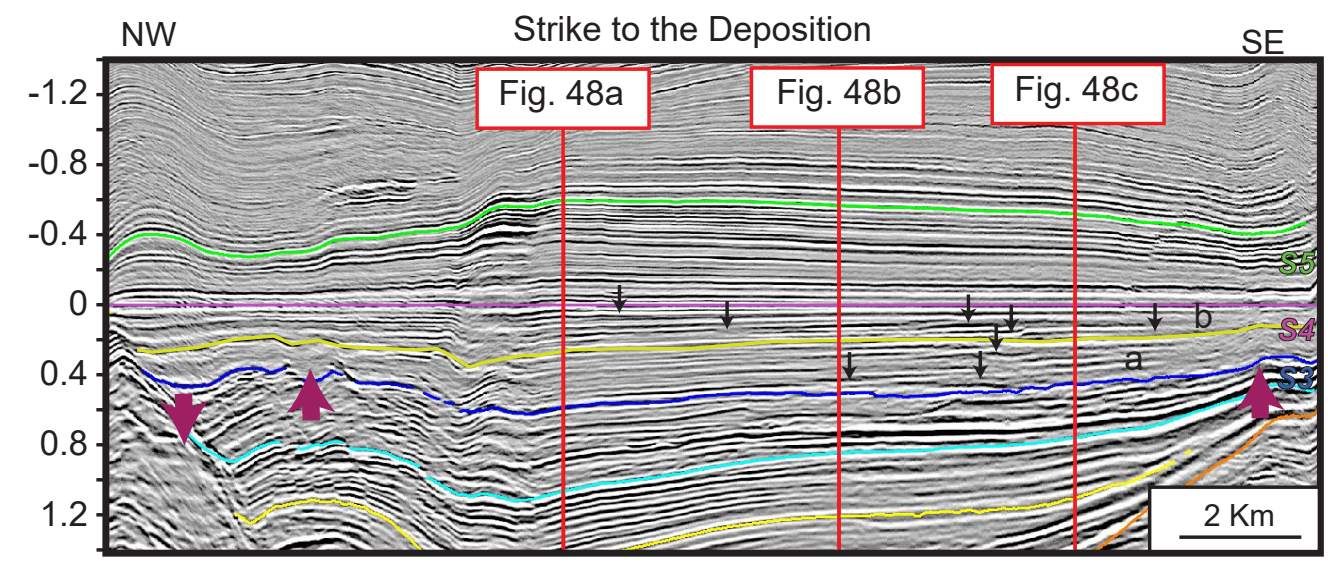

(d)

이 듬

㐫 응

은 으

농

$\pm$

铝

$\infty$

(1)

우

노 

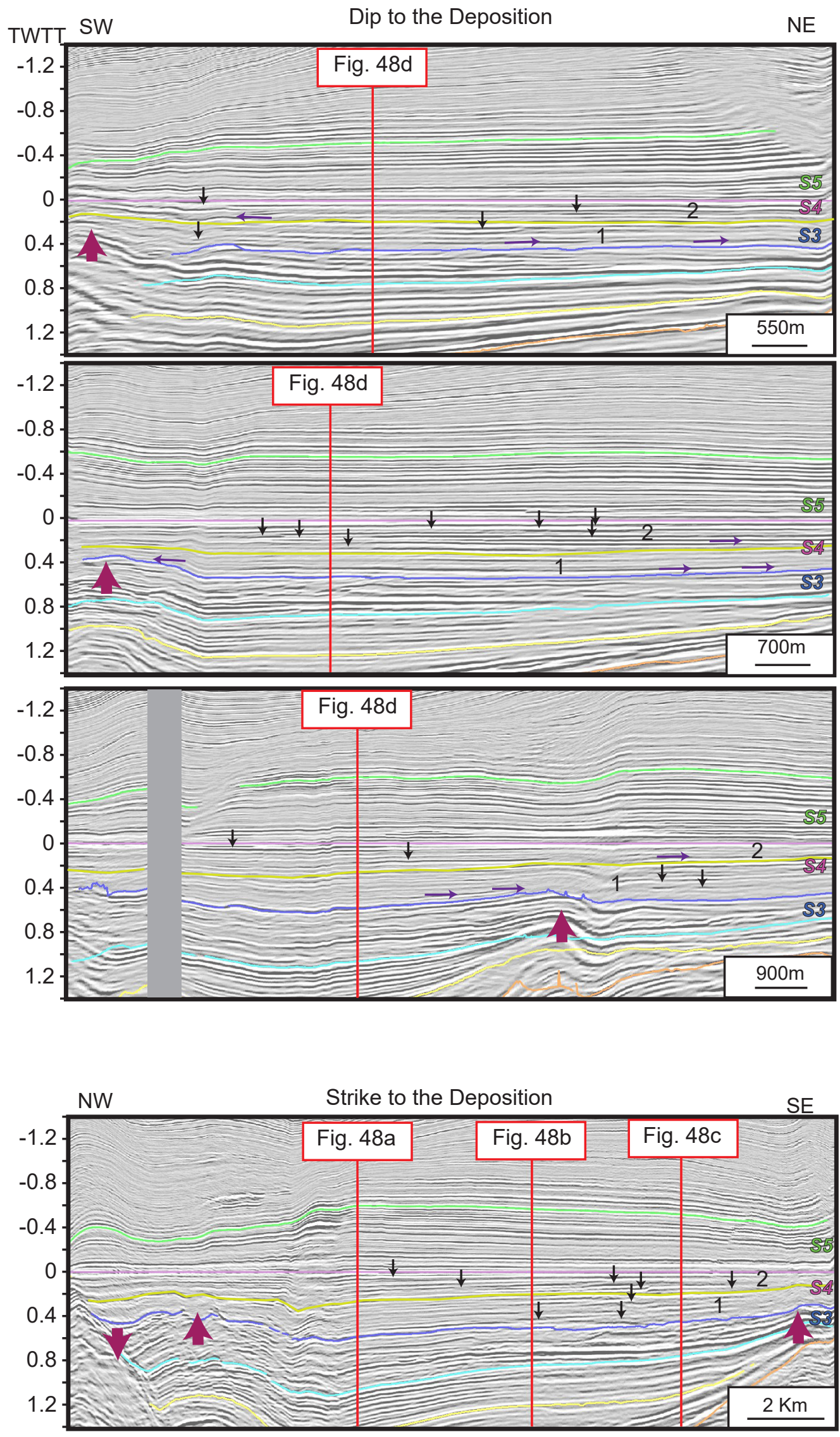

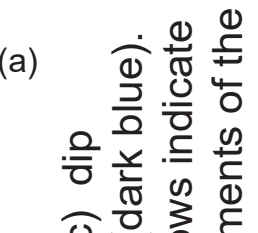
ช เ ऽ v

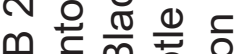
윽 임을 ज

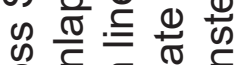

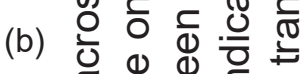

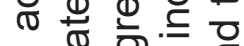
$\checkmark$ ชิ

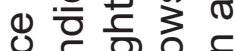
드.으 은 든 ฯ

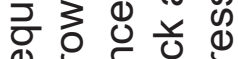
ஸ 는 등 응 ()

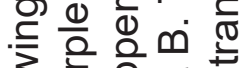
은 는 는 ज $0 D \pm$ (c) $\frac{1}{2}$ 을 을 얼 홀 은 흐를 은 그을 응

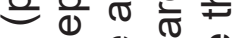

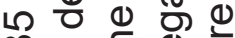
๓ 凹 등 은 으 으 음 य

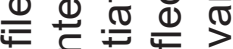

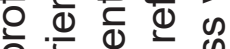
응 잉

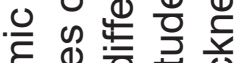
है

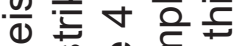
๗ 凹 రত ర

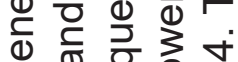

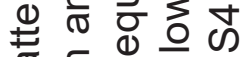
(d) त。 뭉 을 을 은 的六 잉은 궁 은 向 음 는 凹 드 뽀 $\infty$ 의 ๘ $\checkmark$ ஏ ( ) 등 등 잉

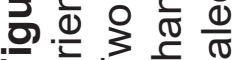
는 능 

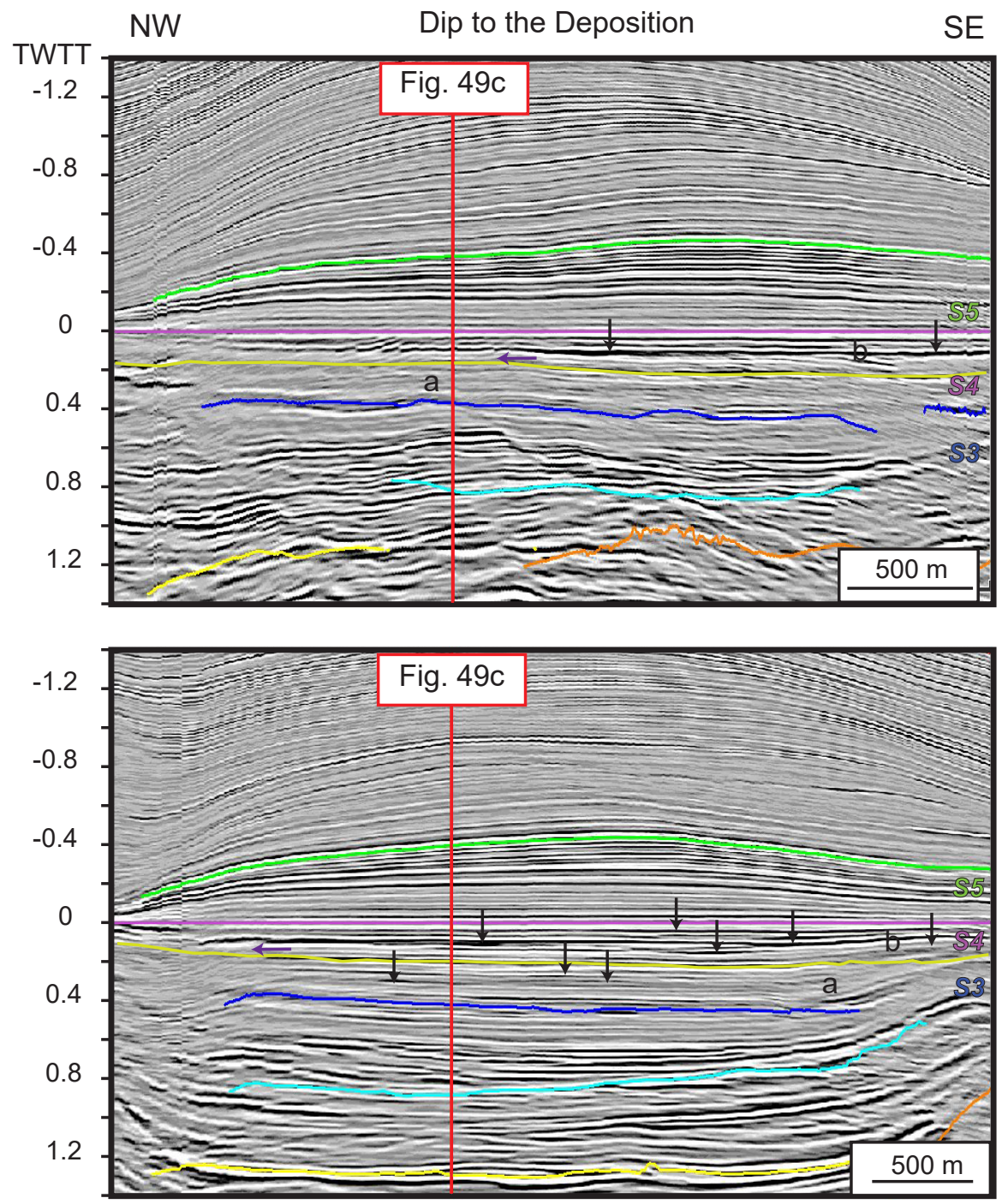

(b) 凹

(a)

으

(I)

$\ddot{m}$

음

윽 유

里

은 으

는

$\checkmark . \subseteq$

ป ई

ठ

这

욤.

이으

긍

응

क

(1)

은 응

르 임

누우

ल 등

ᄃ

क)

은

을 क

을

के

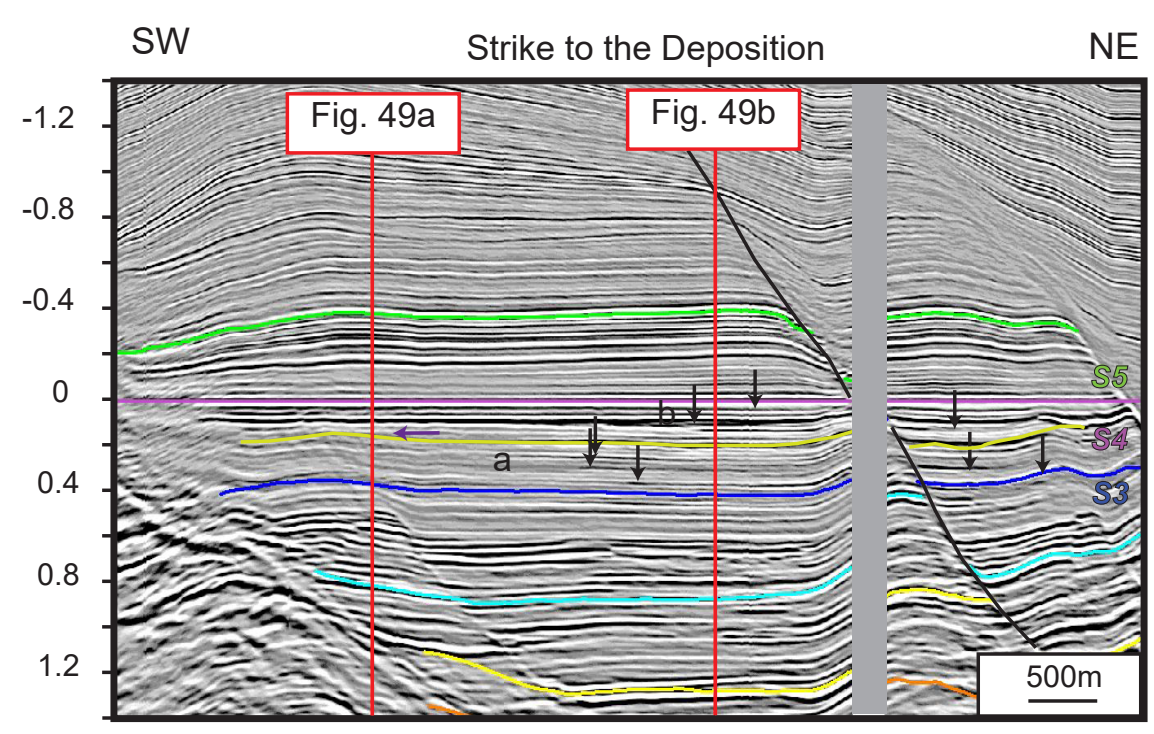

ब(

(c)

$\stackrel{\overline{1}}{ \pm}$ 음

元

万

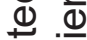

능

은 윽

힘

重

字 

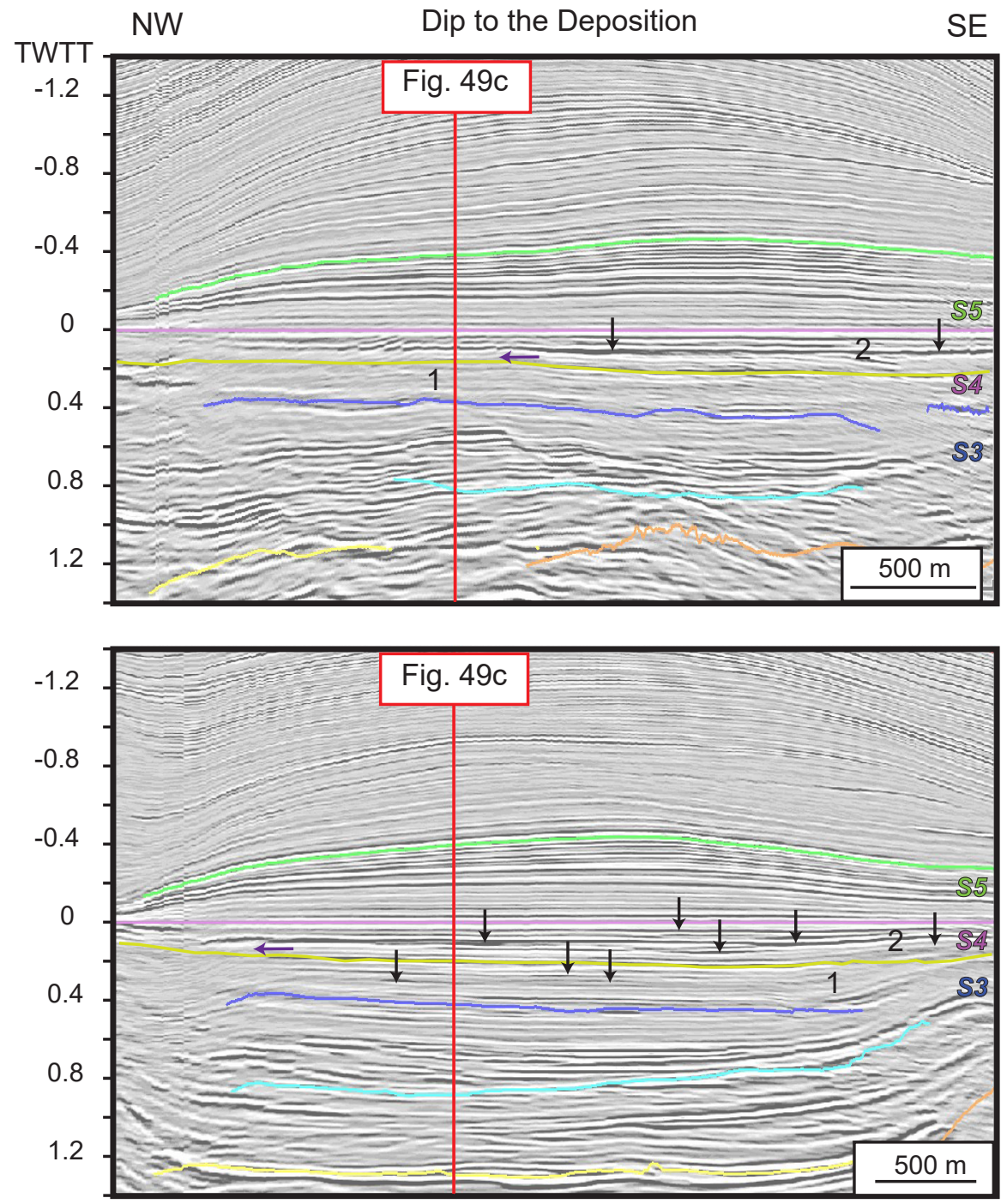

(b)

(a) $\dot{\text { (1) }} \stackrel{\circ}{3}$ 음 흥 离 ลำ 흥 ำ

1 으응

त्व

लं

$m$ 든

슥 응 仓

ब

क 口

웡 Ф 응

ช

$\checkmark$ 응 음

ه.

䛃

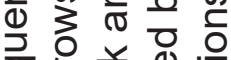

ठ는

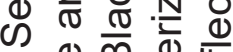

잉 $\frac{0}{4}$

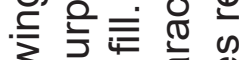

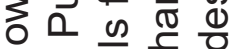

क ᄃ

(1) 을 들 믈

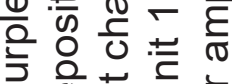

으웡 Ф)

ᄂ 10 击.

品

の $\overline{0}$

ㄷํㄴํำ

क 巳

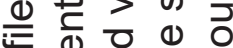

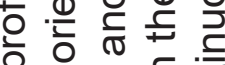

舟 $\bar{\sigma}$

일 Ð

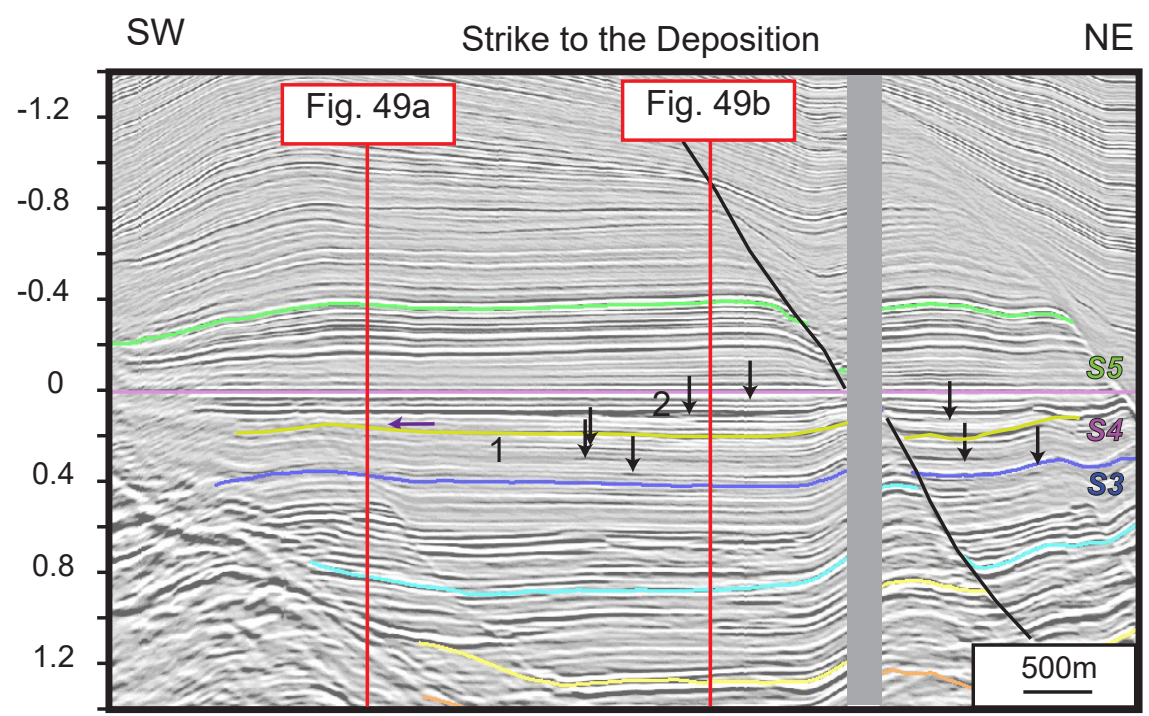

(c) $\frac{\omega}{0}$ 竞

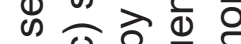

ช 으르

¿ 잉 0

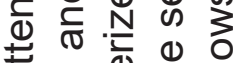

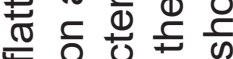

4 을 잉 0

ब

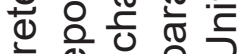

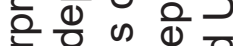

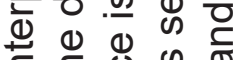
펃 凹

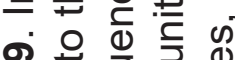

운 옥

๑ 엉 ত 즐

ป 는

은 응 는 은 


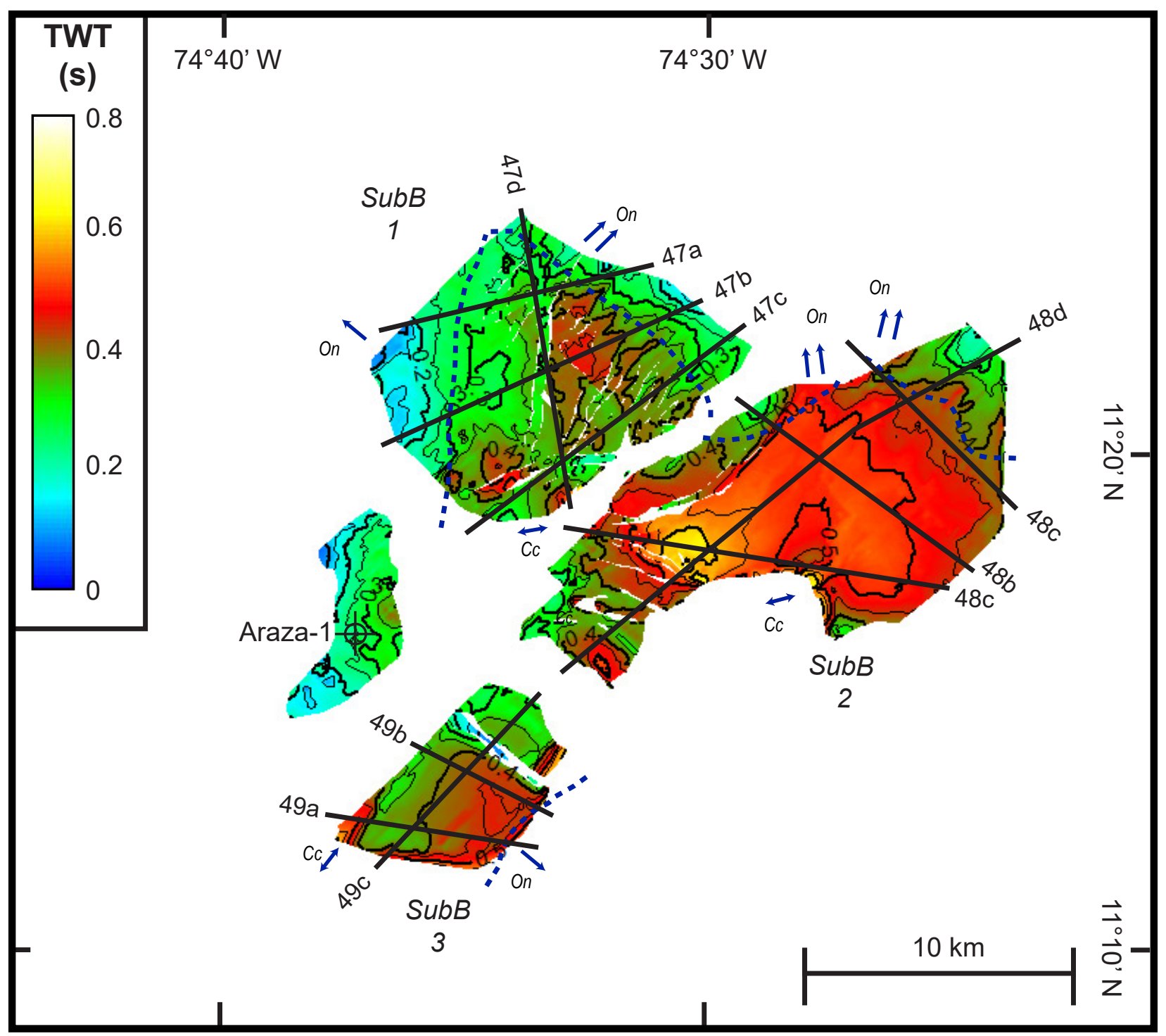

Figure 50. Isochron map of Sequence 4. Warm colors indicate thicker areas. Contour interval is 0.05 seconds (TWTT). Blue arrows indicate onlap direction. Dashed lines show transition from concordand to onlapping reflections. On: Onlap Cc: Concordant. 


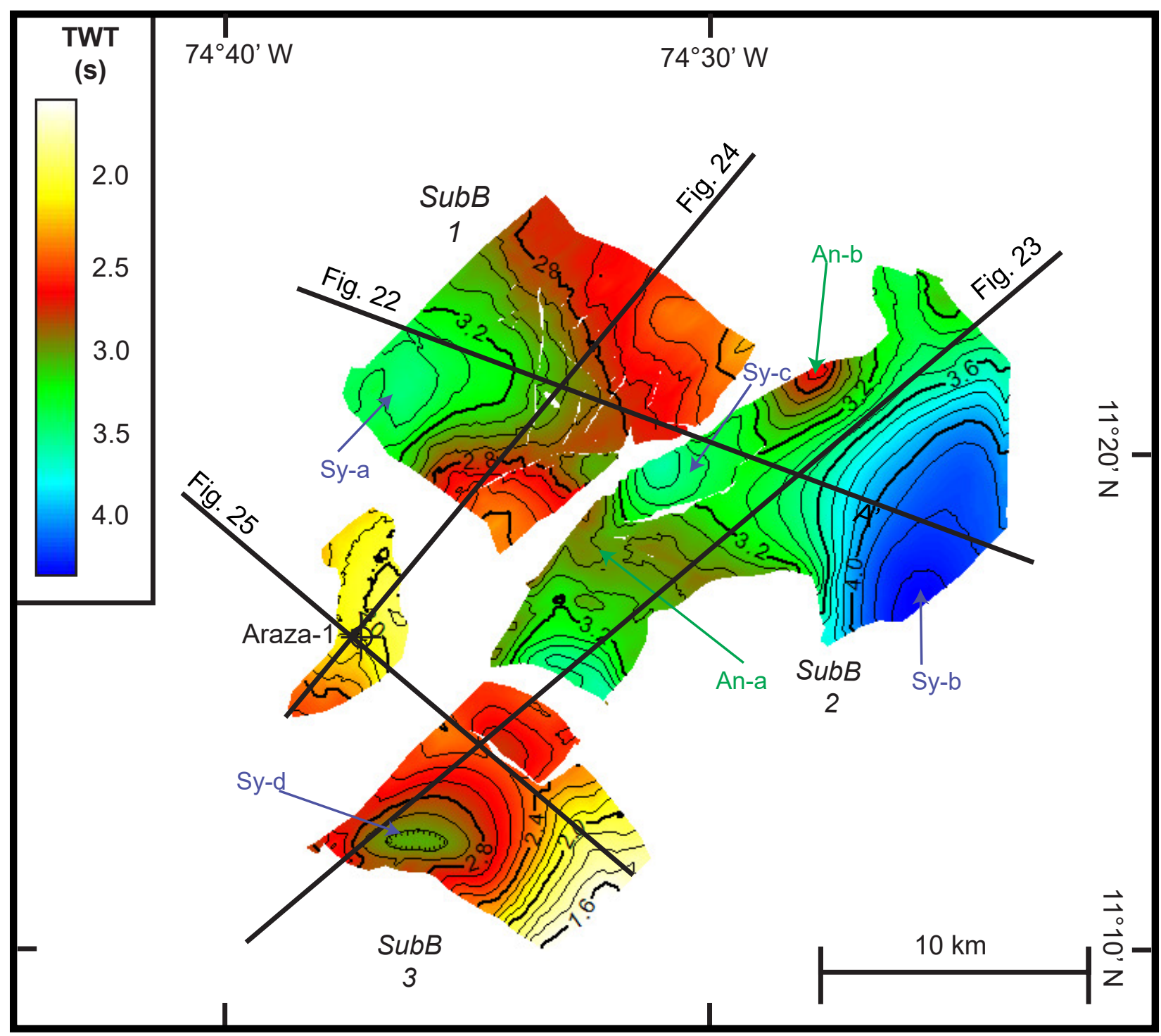

Figure 51. Time structure map at top of Sequence 4 (SB5). Warm colors indicate structural highs and cool colors lows areas. Contour interval 0.1 seconds (TWTT). Anticlines (An) and Synclines (Sy) are labeled. 


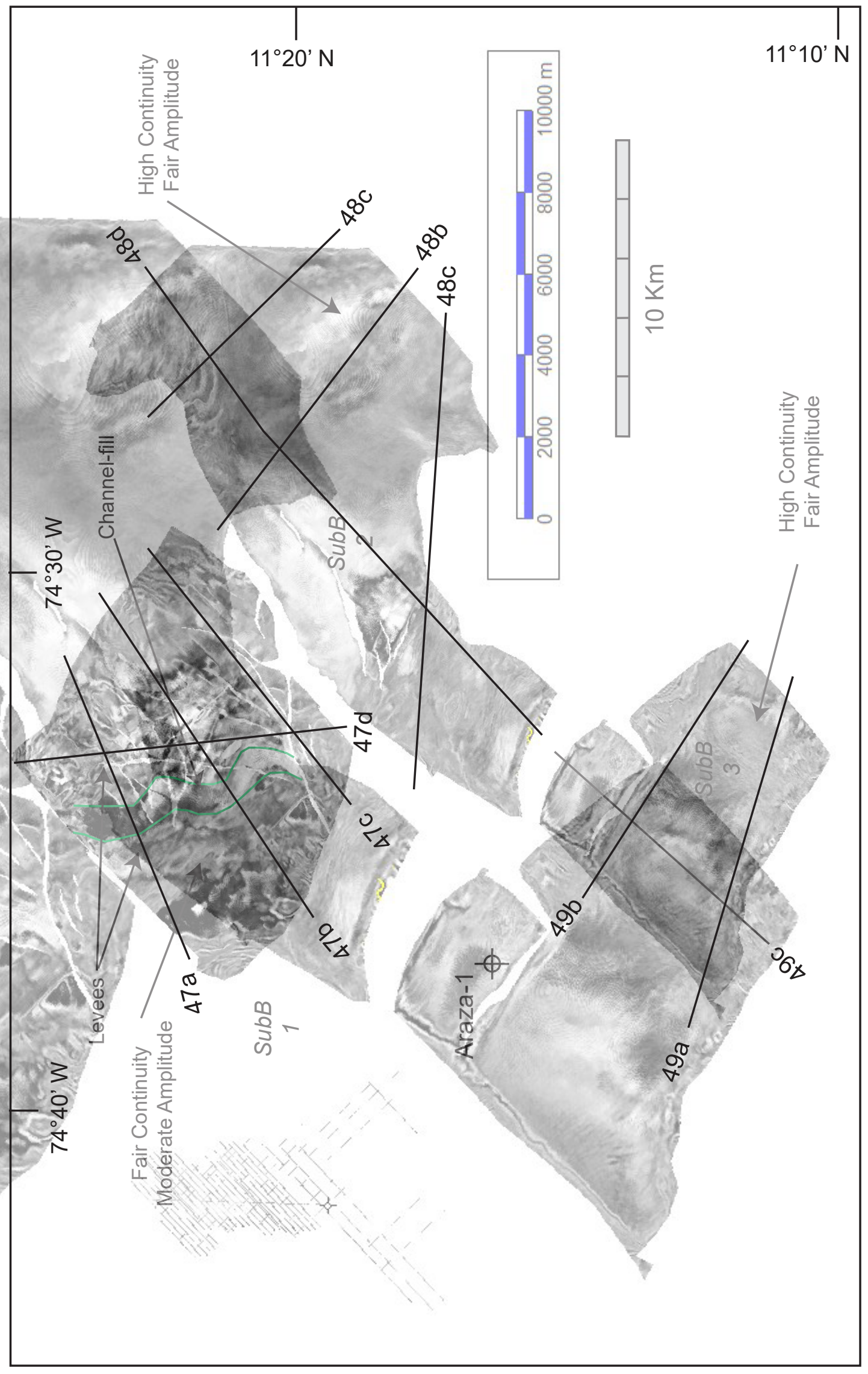

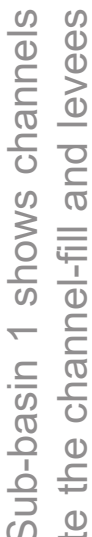

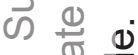

ต

心 으를

등

(ᄈ) 음

음

Es

$\sum \stackrel{0}{0}$

E⿱ㅗㄹ 음

응 을 인

든

汱

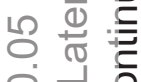

$0-10$

षㄷํㄹ

언 읃 을

ब1

헝워

ल ल

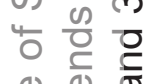

ญ ญ ত

क ष

들

$N$ 川 $\pi$

Nㅡㅇ 웅

도 응 윽

그를

๑ 0.

ํํㅇ

은 응 웜 


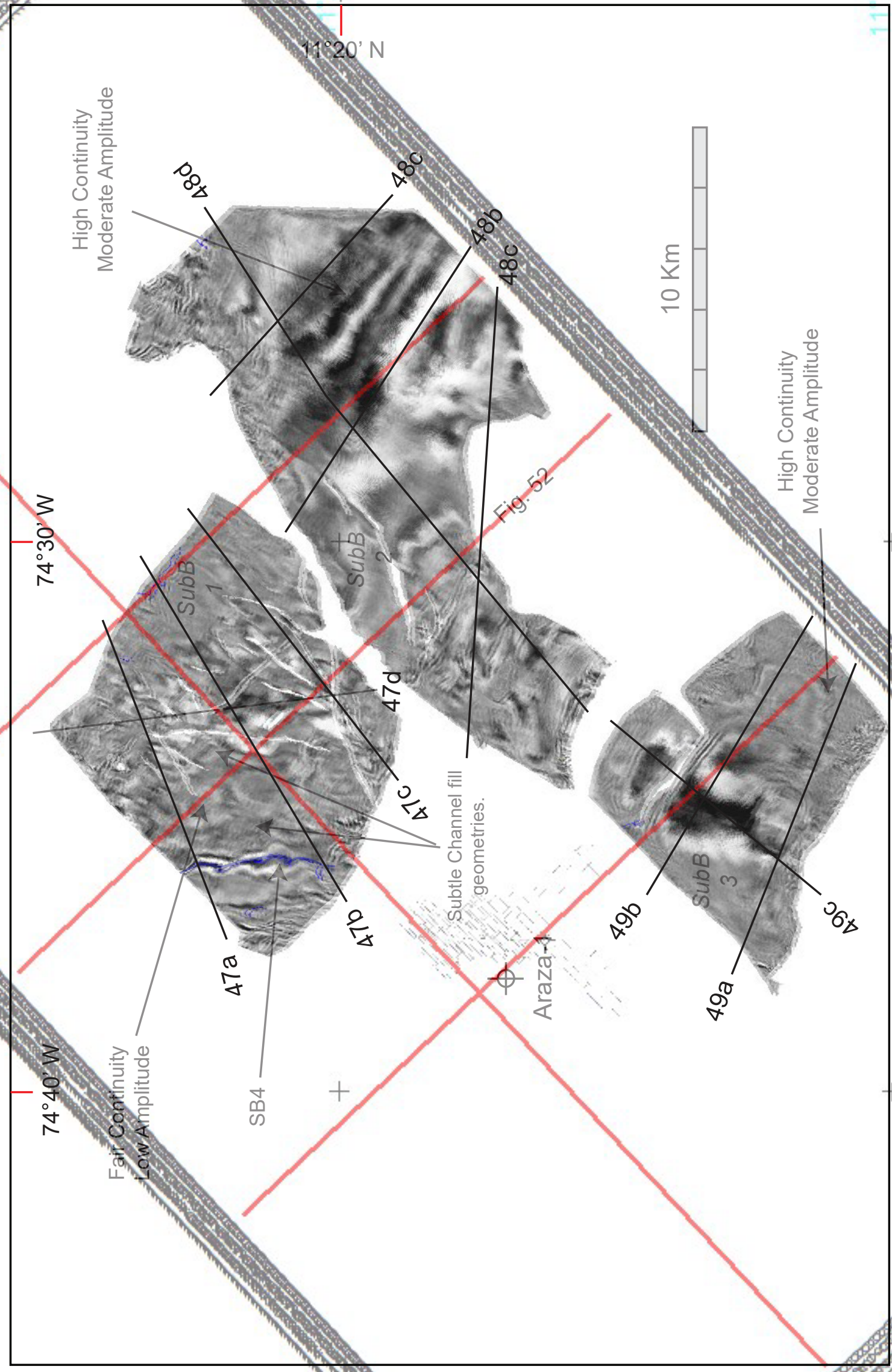


Sub-basin 3 displays two internal units, similar to sub-basin 2 (Figure 49). Unit 1 has subparallel reflections with good continuity and fair amplitude. To the southeast, the units are poorly imaged. Unit 2 has subparallel reflections with better amplitude and good continuity (Figure 49). The unit onlaps onto Unit 1 at the southeast part of the sub-basin. Some lateral shifting at the center part of sub-basin 3 indicates likely the center channelfill geometries of stacked channel-levee complexes (Figure 49). The horizon maps show similar facies characteristics as sub-basin 2. Subtle lateral facies vary in subtle wedges of the stacked channel-levee complexes (Figures 52 - 53).

\section{Geologic Interpretation}

In sub-basin 1, heavily channelized lithofacies is present in sequence 4. Two internal units are distinguishable by the amplitude of the reflections. The lower units display reflections with less continuous and amplitude. The upper unit has erosional surface filled by subparallel reflections with better continuity and higher amplitudes. Likely, the changes in seismic facies indicate different lithology of the sediments.

Sub-basins 2 and 3 have similar of the seismic patterns. Two internal units are present in the sub-basins. Unit 1 is characterized by highly continuous reflections that onlap onto SB4 in the north (Figure 48). To the southwest in sub-basin 3, the reflections are concordant to SB4 (Figure 49). A subtle paleo-topography of sequence 4 controls the sedimentology of Unit 1 in the two sub-basins. To the southeast, there is decrease in amplitude (Figures 48 - 49). In sub-basin 3, the reflections overlie a prominent paleohigh of TS1 in the south, in contrast to sub-basin 2, the reflections are concordant overlying the upper reflections of sequence 3 . Unit 2 shows higher amplitude reflections with good continuity. The subtle lateral variation phase indicates a stacked channel-levee 
complexes system along Unit 2 in sub-basins 2 and 3 (Figures 48 - 49). The units onlap onto Unit 1 to the northwest and the southeast of the sub-basins.

\section{Sequence 5}

$\underline{\text { Key Surfaces }}$

Sequence 5 is bounded by SB5 at its base and SB6 at its top. In sub-basin 1, the basal reflections onlap onto SB5 to the northwest (Figures 54, 57). The reflections are concordant overlying the lower boundary in the southern part of the sub-basin (Figures $54,57)$.

In sub-basin 2, the basal reflections are concordant over SB5 (Figures 55, 57). To the north, the basal reflections onlap onto SB5 (Figure 57).

In sub-basin 3, the basal reflections onlap onto the lower boundary to the northwest and to the southeast parts of the basin (Figures $56-57$ ). In the central part, the lower reflections are concordant overlying SB5 (Figures 56).

In all three sub-basins, the upper reflections are concordant with SB6 (Figures 54 - 57).

\section{$\underline{\text { Time-Structure Map }}$}

The sequence boundary (SB6) ranges from 1.3 to 3.7 seconds (TWTT) (Figure 58).

In sub-basin 1, SB6 ranges from 3.2 to 2.1 seconds (TWTT). A prominent syncline (Sya) is present in the northern part of the sub-basin, where it reaches the deepest point (3.2 seconds). The structure shallows to the south until 2.1 seconds (TWTT) (Figures 22, 25, 58). 
In sub-basin 2, SB6 varies from 2.2 to 3.7 seconds (TWTT). The deepest point is in the southwest, in the center of the prominent syncline (Sy-b). To the west, the structure shallows gently, and then deepens to the western part of the sub-basin (Figures 22, 58). In the north, adjacent to Fault B, small partial structures (anticlines and synclines) are cut by the faults. The shallow anticlines have three-way closure (An-b north and An-a) against Fault B; the syncline (Sy-C) is cut by Fault B and a prominent shear fault to the south.

In Sub-basin 3, SB6 ranges from 1.3 to 2.6 seconds; SB6 is deepest to the south (2.5 seconds) in the central part of a prominent syncline (Sy-d) (Figures 25, 58). The horizon shallows to the north and east, reaching 1.3 seconds (TWTT) (Figures 23, 58). A slight offset in the northern part of the structure is affected by a normal listric fault (Figure 58).

The sequence in the Araza High is completely eroded by the Upper Miocene Unconformity (UMU) (Figures 24, 25).

\section{Isochron Map}

Sequence 5 varies in time values from 0.15 to 0.6 seconds (TWTT) (Figure 57). Subbasin 1 , time values range from 0.15 to 0.5 seconds. It is thickest to the south, where the iso-thick trends subparallel to Fault B. The sequence thins over the northwest of the subbasin.

In sub-basin 2, the sequence varies from 0.7 to 0.2 seconds (TWTT). The thickest area in the south-central area. To the north S5 thins gradually to 0.2 seconds. The thickness trends between sub-basin 1 and 2 are similar suggesting that they may have been connected. To the southwest, a local iso-thick trends parallel to the normal faults (Figure 57). 
In sub-basin 3, the sequence ranges between 0.25 and 0.45 seconds, and thickens to the south, where it reaches the thickest area ( 0.4 seconds) to the south-central part (Figure 57).

Seismic Facies (Internal Description)

Two internal units (1-2) are present in sub-basin 1 . Unit 1 is dominantly subparallel reflections with good continuity and lateral amplitude changes along the area (Figure 54). Two prominent channels are present in sub-basin 1 . The channel-fill to the south overlays a subtle paleo-high, and trends to migrate obliquely to the south. The channels to the north trend to migrate to the northwest. Unit 1 thins and onlaps onto SB5 to the southern and northern parts of the sub-basin. The horizon map extraction beneath 0.2 seconds (TWTT) of SB5 shows sinuosity geometries that trend to the northeast (Figure 59). Unit 2 is characterized by continuous parallel reflections with low amplitude. The unit onlaps to the south onto Unit 1. The horizon map extraction beneath 0.05 seconds (TWTT) shows good continuity and low amplitude of Unit 2 along sub-basin 1 (Figure 60).

In sub-basin 2, three internal wedge units (1-3) are distinguishable that are offset laterally (Figure 55). The lower unit (1) is the thinnest of the three units, and thins to the southeast (Figure 55). The reflections are parallel with good continuity and fair amplitude. The middle unit (2) thins to the north, in contrast to Unit 1. Reflections are parallel, with high continuity and moderate amplitude. The reflections lose amplitude to the northwest. In the upper unit (3), the reflections are parallel to subparallel, with moderate amplitude. The unit has constant thickness along sub-basin 2. The basal reflections have subtle lens geometries of channel-levee complexes (Figure 55). The two horizon maps image Unit 3. The 0.05 seconds map shows an uniform seismic pattern with highly continuity (Figure 
60). The 0.2 seconds shows lateral amplitude variation, characteristic of shift between levees and the channel-fill (Figure 59).

In sub-basin 3, three similar internal units are present (Figure 56). Unit 1 thins to the south, and Units B and C thin to the north. In other words, sub-basins 2 and 3 were connected during sequence 5 deposition.

Geologic Interpretation

Sub-basin 1 is characterized by continuous sub-parallel reflections of the channel-levee complexes. The channels stack obliquely to the south and the north part of the sub-basin (Figure 54). The sequence onlaps onto SB5. Channel geometries above the sequence boundary indicate incised channels over sequence 4 (Figure 54).

Sub-basins 2 and 3 are interpreted together due to the similarity of seismic pattern (Figures 55 - 56). Three internal units are present. Unit 1 is characterized by continuous reflections that truncate in the central part of Sub-basin 2 against Unit 2 (Figure 55). In sub-basin 3, the unit is thicker and onlaps onto SB5 to the northwest and southeast (Figure 56). Unit 2 has good continuous reflections along the sub-basins. In sub-basin 2, the reflections lose amplitudes to the northwest. In sub-basin 3 the unit is thinner and onlaps onto Unit 1 in the northwestern and southeastern parts of the sub-basin. Unit 3 in sub-basin 2 displays basal reflections that onlap subtly onto the horizon between Units B and $\mathrm{C}$. These geometries indicate incised channels in the lower part of Unit 3. The units thinnest towards sub-basin 3 and onlaps onto unit 2 at the northwest and southeast. The continuity in the three units indicates drape sediments that fill entirely the two sub-basins. 


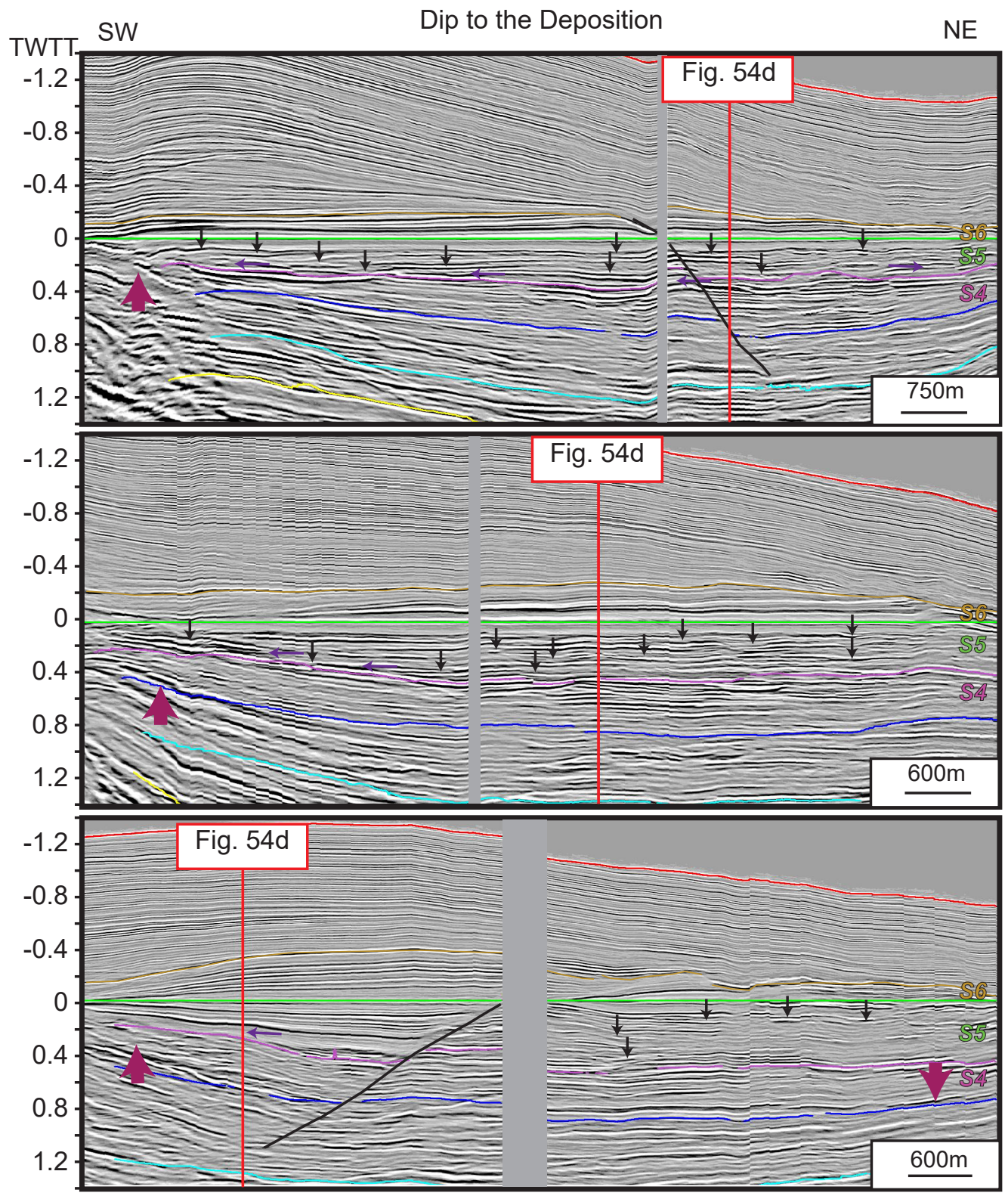

(a)

$\ddot{-}$

$m$

ํำ

क م

인

인

0 은

음.

(b) $10 \sum^{2}$

ญ

ब)

ำ

ס

ผ 으

이류

.

วิ

क :

드응

ฮ

흐우

(c)

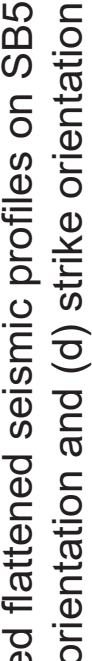

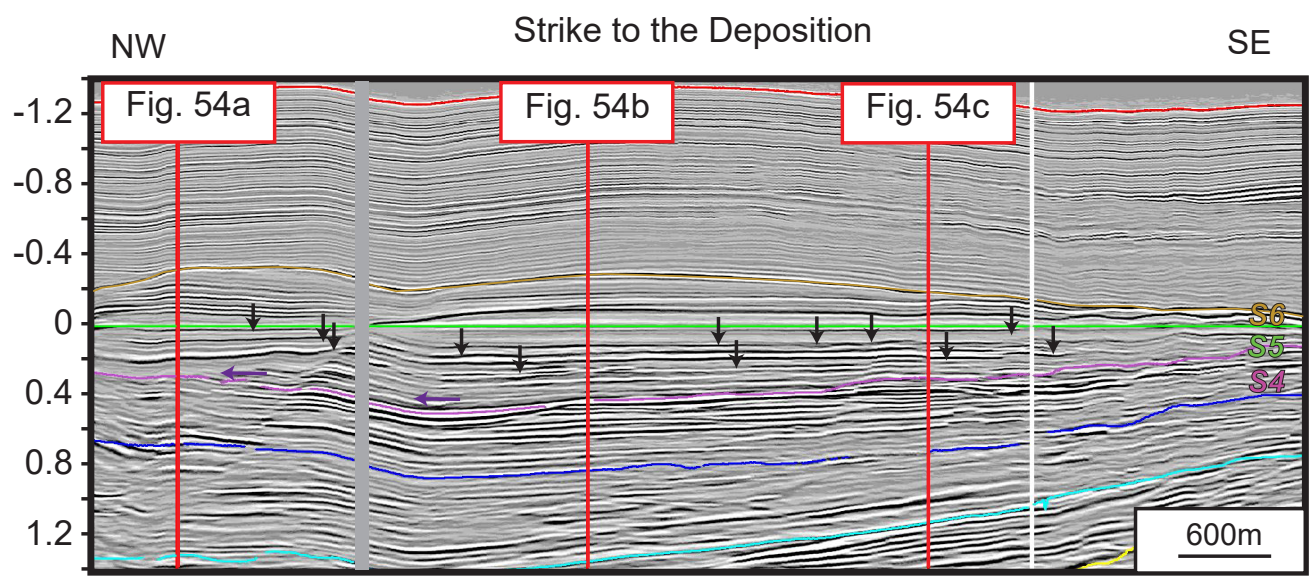

(d)

호응

은 응

인

.

ธิ

में

온 


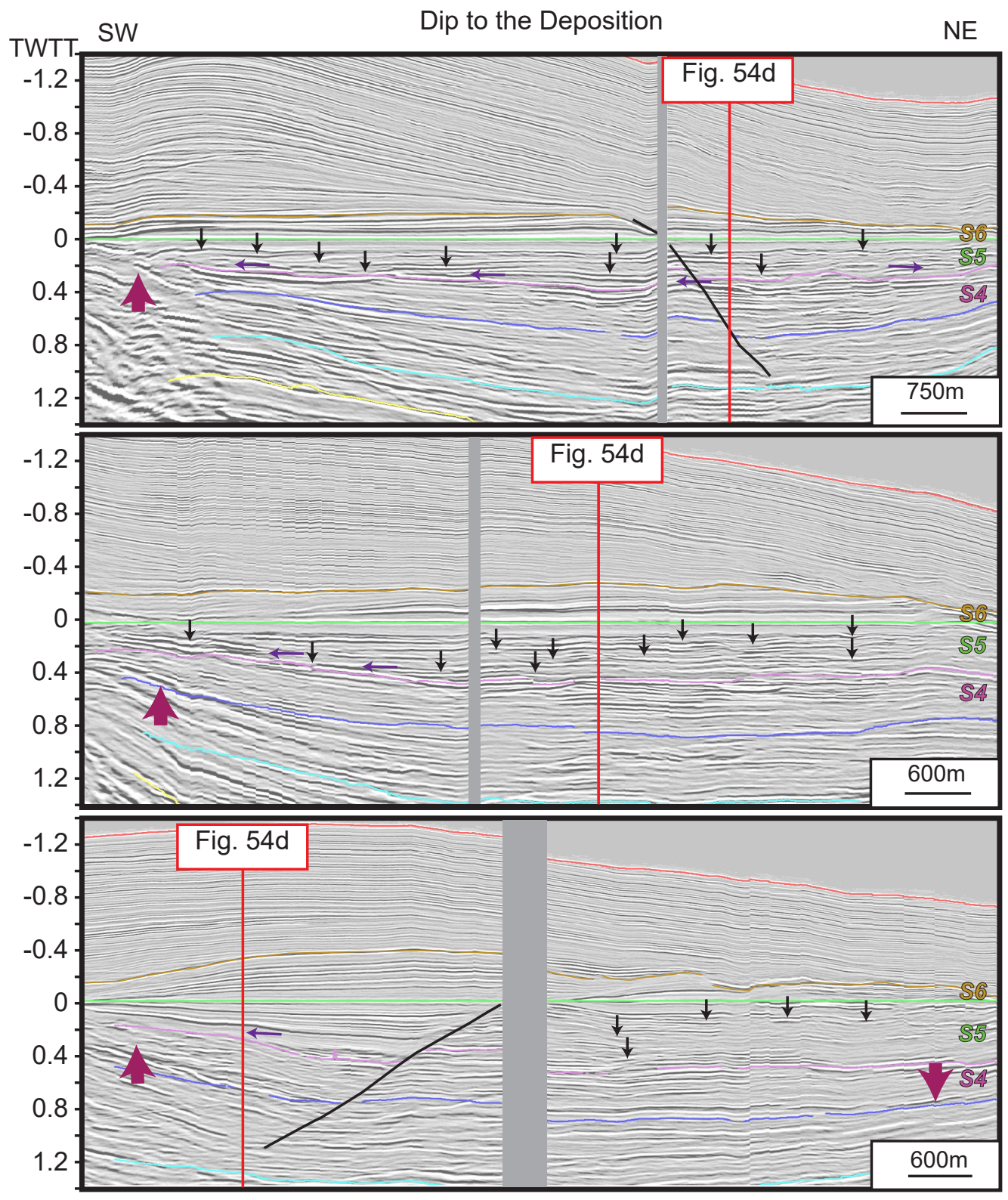

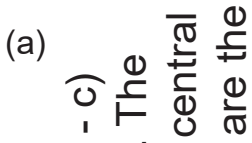

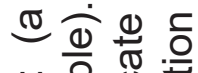

$\because$ 은 $\frac{0}{7}$

을. 흐

क

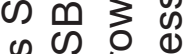

की 0 흐 $\frac{1}{x}$

는

๙ 0 它

(b) 0 은

$\frac{0}{0} \frac{1}{\frac{0}{2}}$

宁 ठ

\%

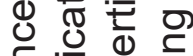

응

긍.马 응

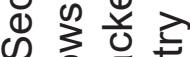

0 은

के थ ह

उิ

的这过。

(c)

ब

@응 응

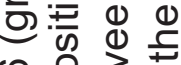

응으응

$\omega \frac{\infty}{0} \stackrel{\omega}{*}$

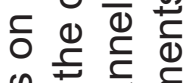

क त ह

đ원

잉 क व

으 들

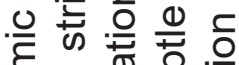

흐융 을

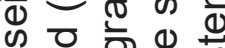

ஸ 등 万ั

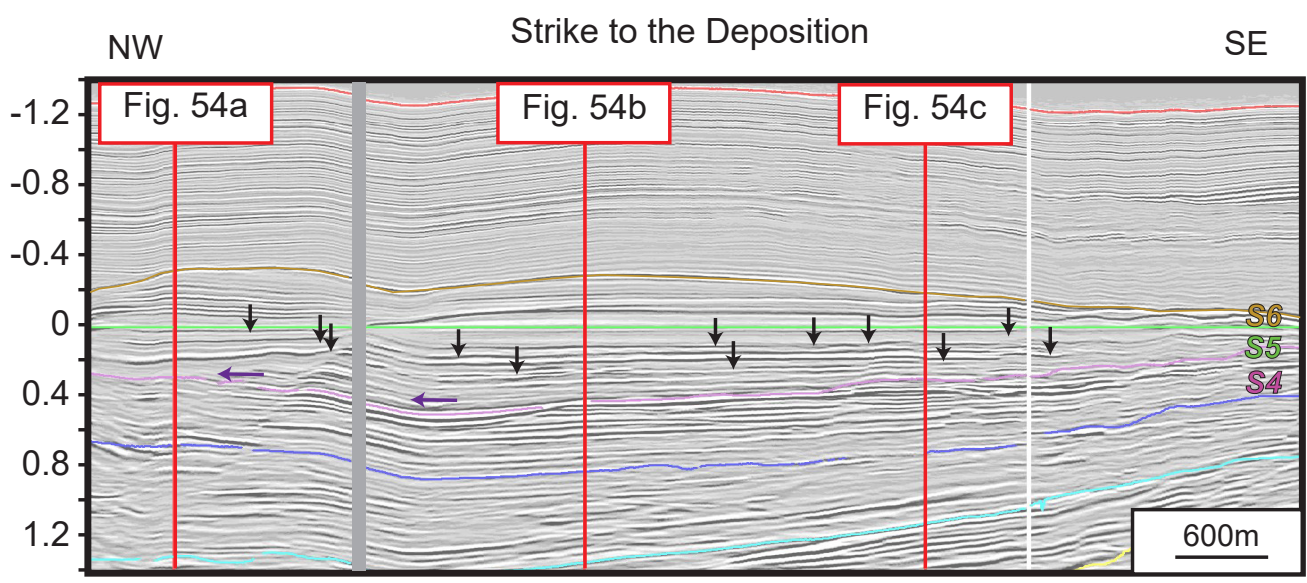

( $)$ 은

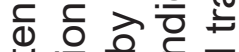
(d) 苋

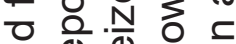
Q $\frac{0}{0}$ ब

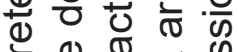
은 등 능 ब( 은 어 $\frac{\infty}{\overline{0}}$ 我过 แ $\frac{\bar{C}}{0} \frac{1}{0}$

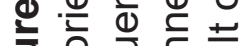
의 흠 으 응 d 등 


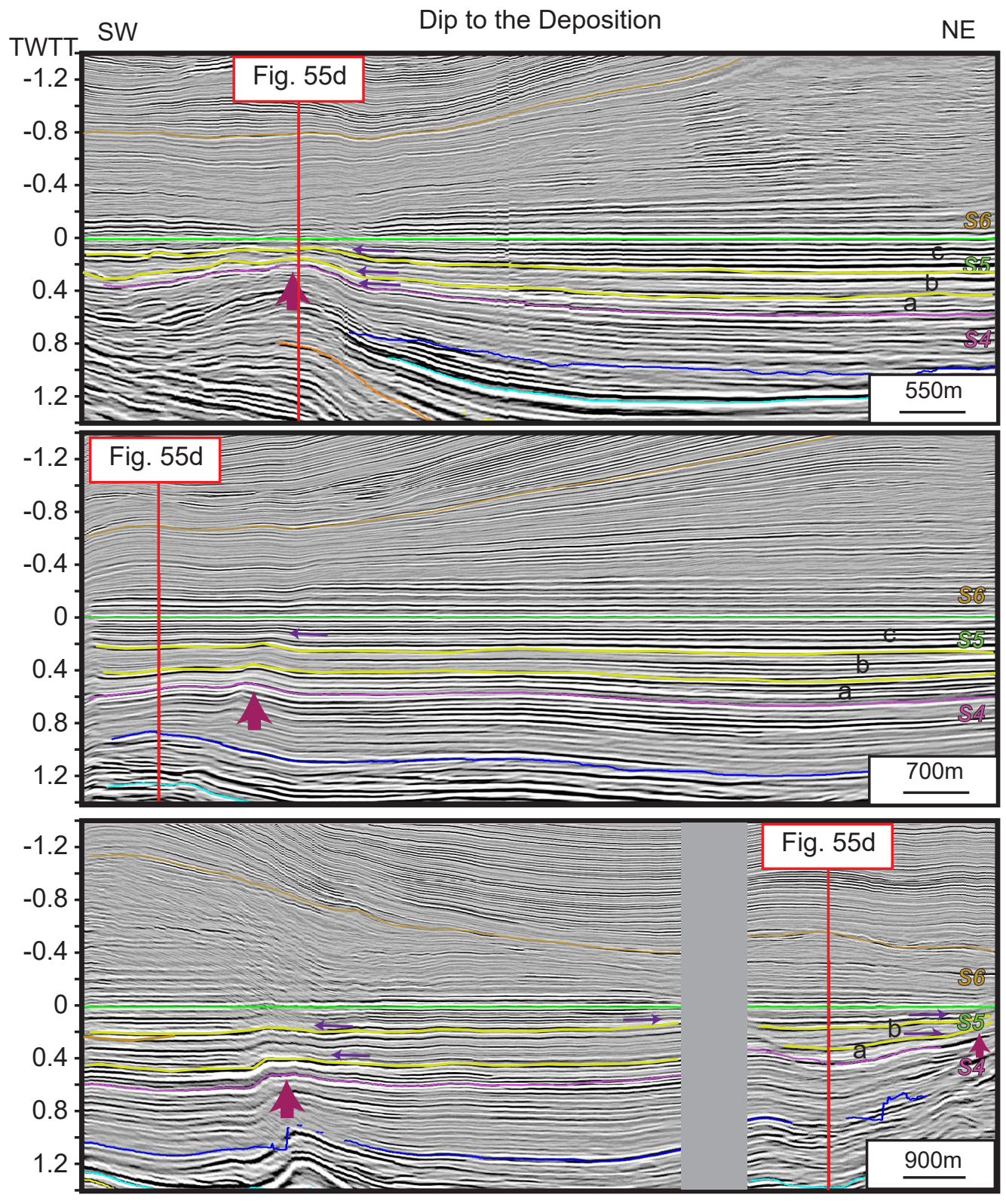

(a) ì

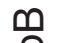

음

(

की 0

닌

즈 으

6 it

므.

㐫

(b)

(1)

ป $\frac{2}{\omega}$

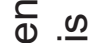

훙

(1) 으

๘

응

3

क

ᄃ 용

ญ

은유

(c)

ᄂ

ज त

등

क ํํ

क

은

으 흔

0 क

है

क

ส

¿

이 음

需

는

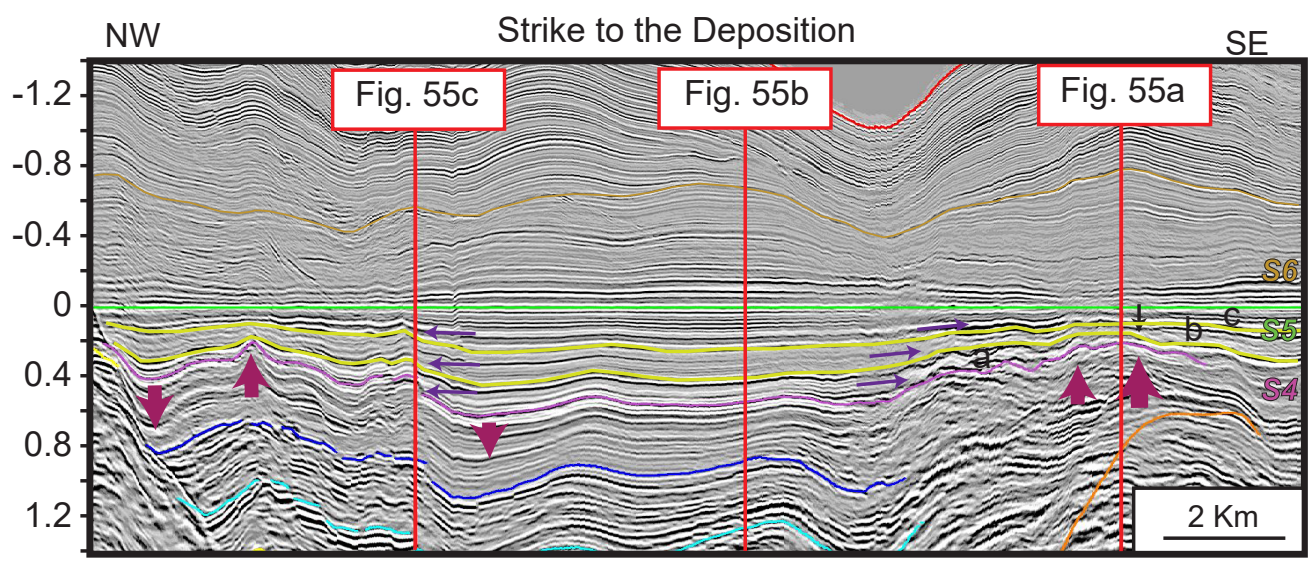

(d)

d) 원 음

过

.

ป

กค

เ

닌

ํำ

iz 

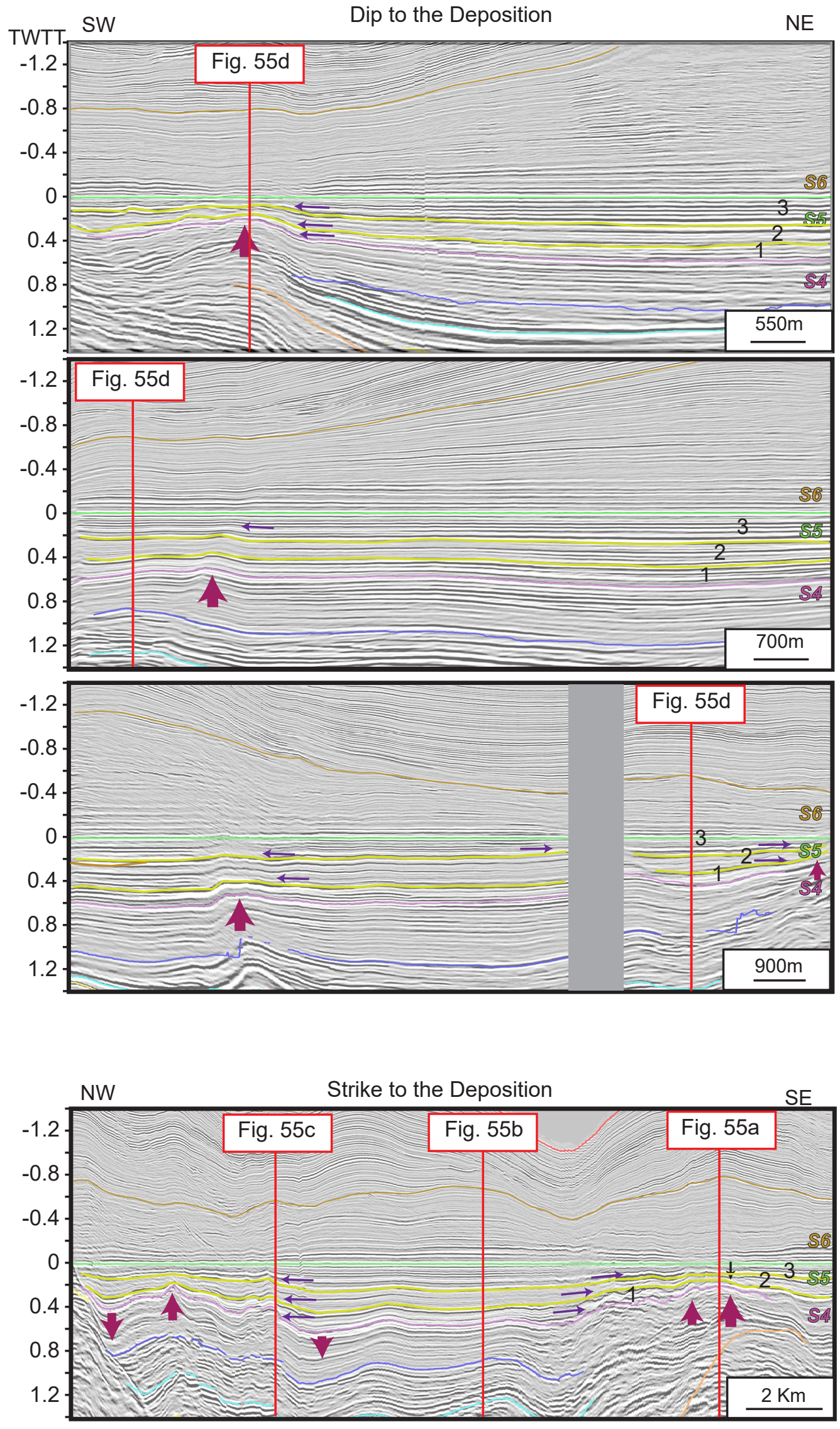

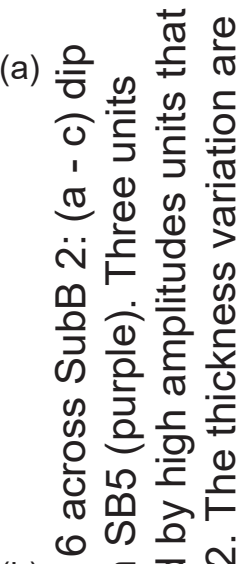

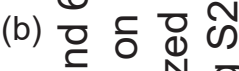

สิ थ Nㅡㄴ

เ $\frac{0}{\overline{0}} \bar{\Phi}$

Q $\frac{0}{2}$

U 중

๑ิ

귱

D) 을

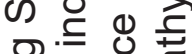

×

ว ว 응

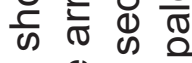

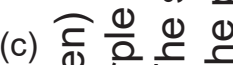

屯 는

क人 $>$ ○े

0 象

은 둥

क : $\stackrel{0}{.}$

ᄃ

웡 ठ응

क व

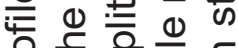

을 을윰

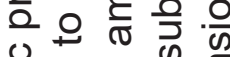

을

क 过茂

心 离导

రত ర

(1) 응

ब ब

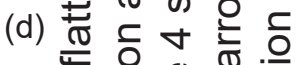

4 을 @

ब क 0 过

屯이웡

은 웡 웡

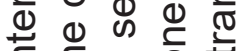

드은

ํํㅇำ 둥

(1) \& 00

는 的은

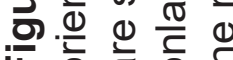



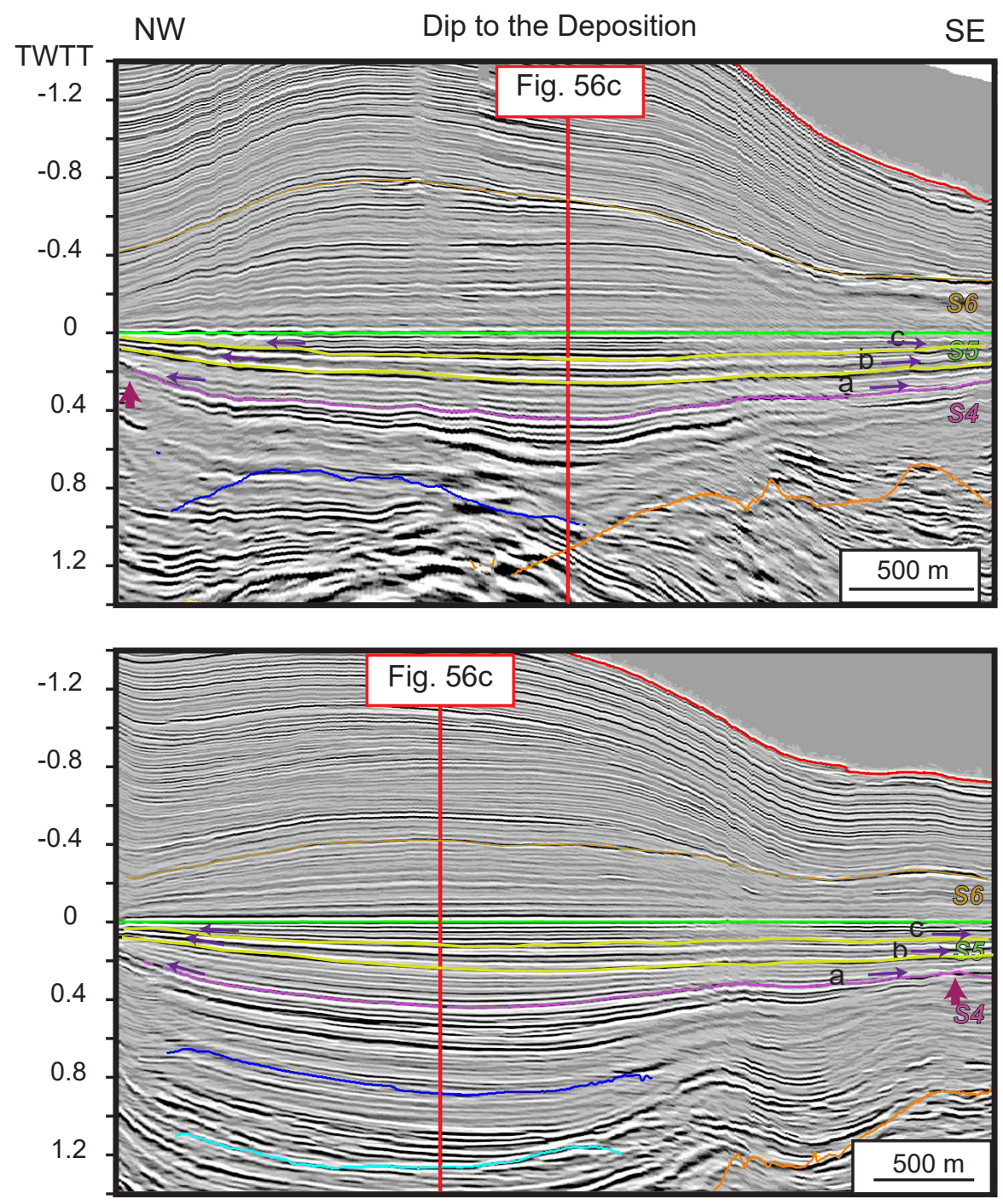

(b)
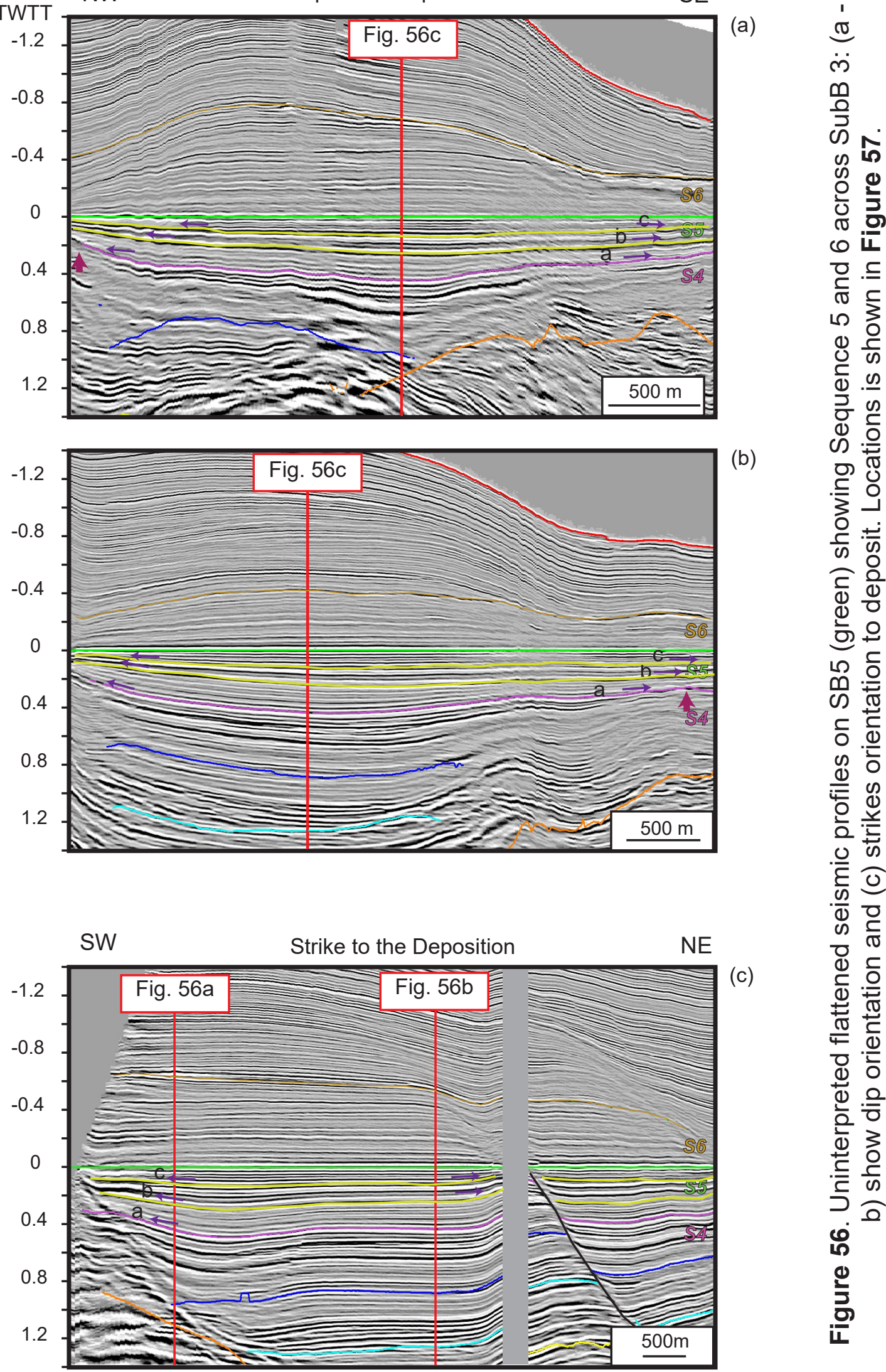

(c) 

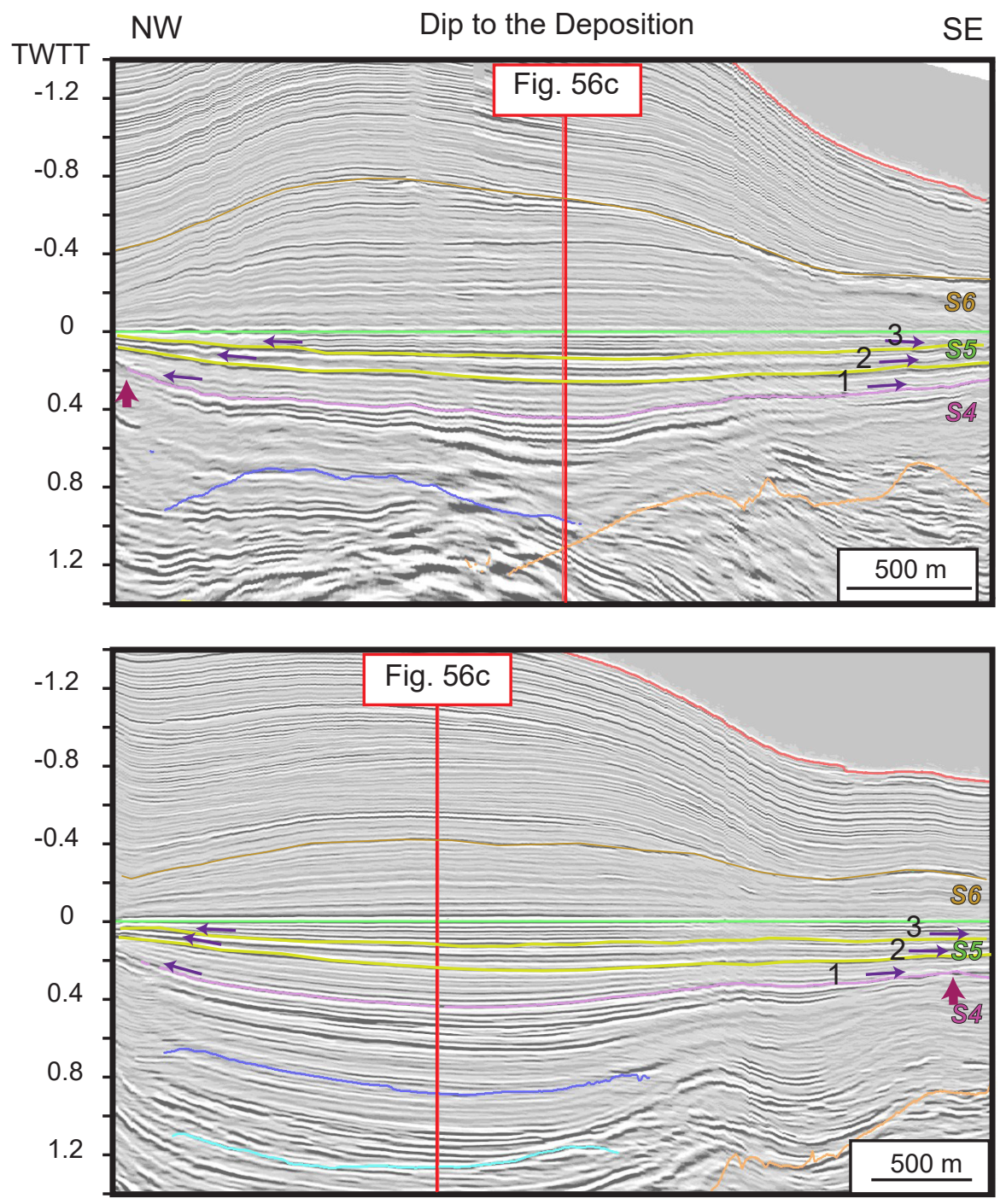

(b)

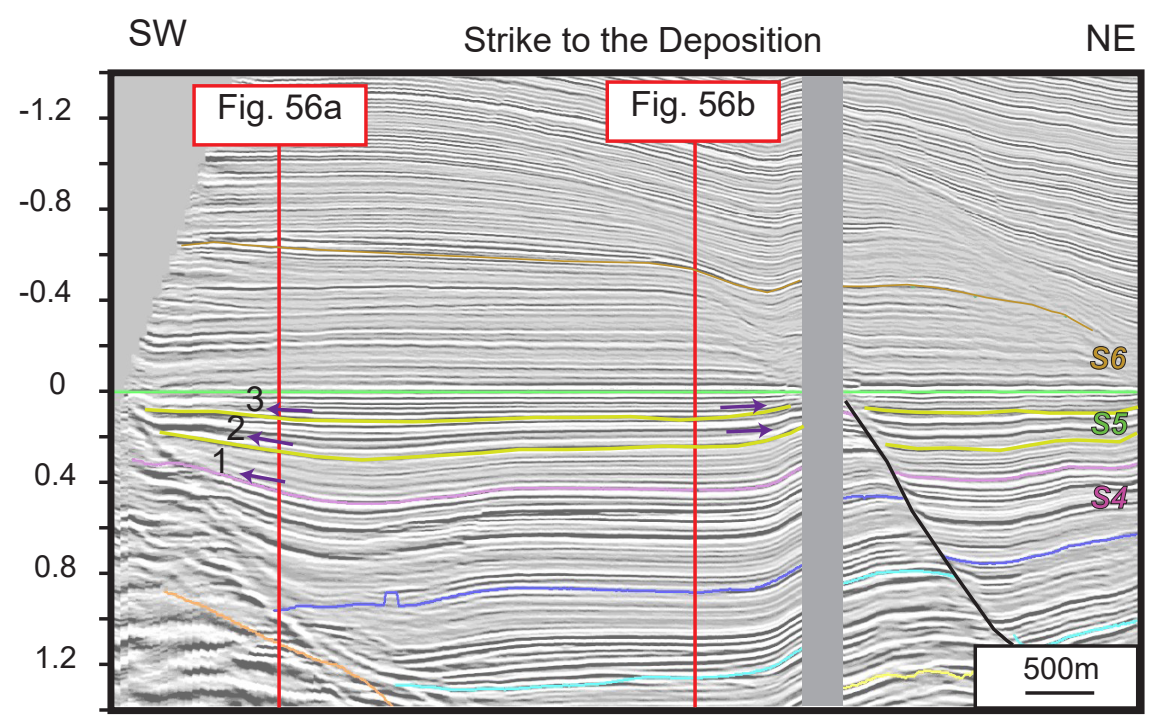

(a)

음

응

띠 으

लं 10

๓

ज을 엉

क क त

잉 응

त) N

0 ธำ

으 导

त 0 잉

ᄂ

ه..

U D D

ఏ)

응 인

ฮ

잉 䗆

든

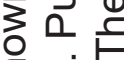

क ठ लं

ᄃ $m$

ఖ

万ब

0

๓

の

드은

क

() 등

힝

응 등

을 ฏ

的突

ब品 兵

क 으응

잉

ब $\frac{1}{0} \stackrel{0}{0}$

స 지

는 응 웡

व

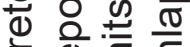

흔 웡 등

Q

$\subseteq £ \varepsilon$

웅응

ถ

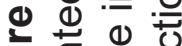

능

으 $\frac{0}{2}$ 


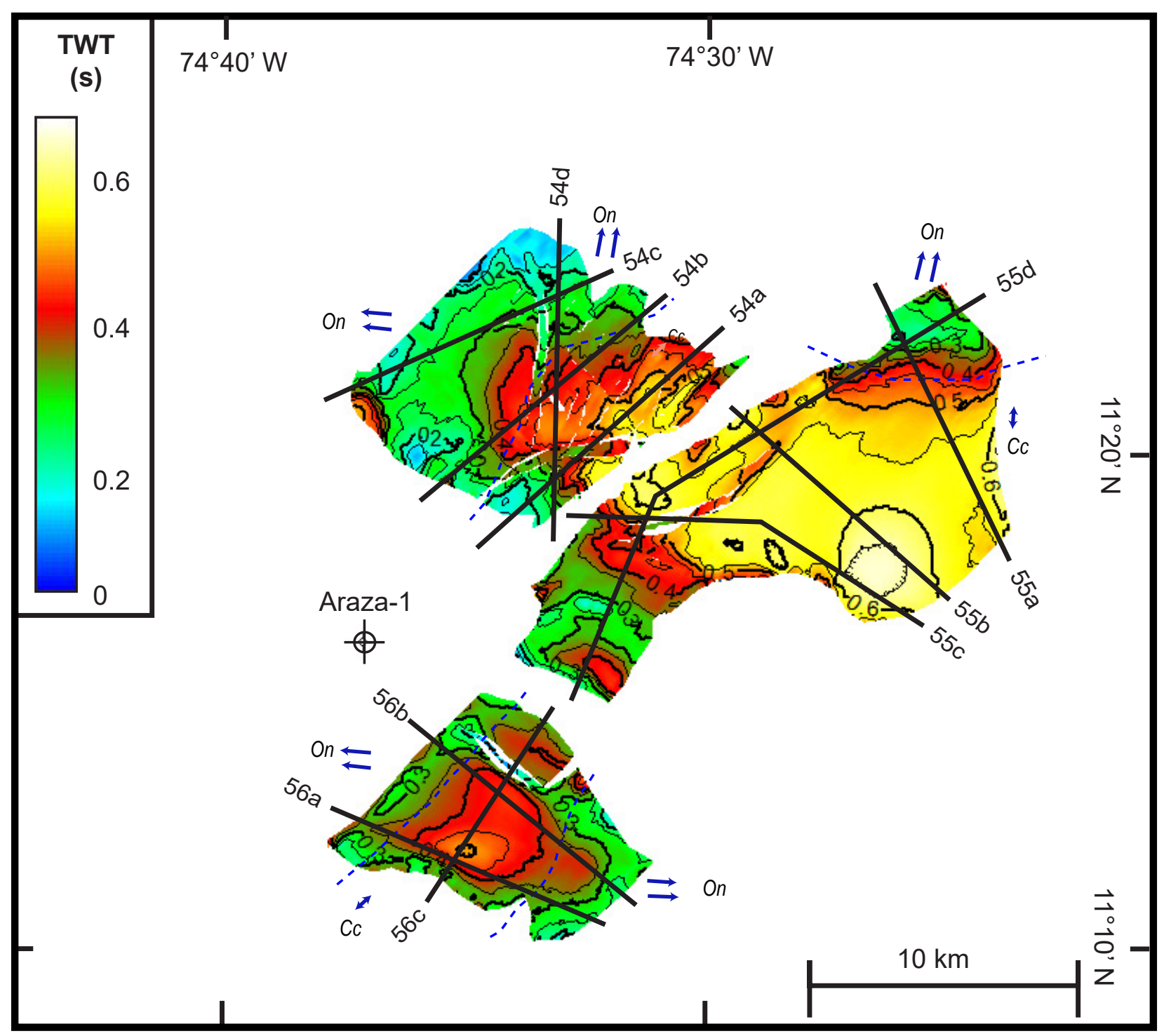

Figure 57. Isochron map of Interval 5. Warm colors indicate thicker areas. Contour interval is 0.05 seconds (TWTT). On: Onlap Cc: Concordant. Blue arrows indicate onlap direction. Dashed lines show transition from concordand to onlapping reflections. On: Onlap Cc: Concordant 


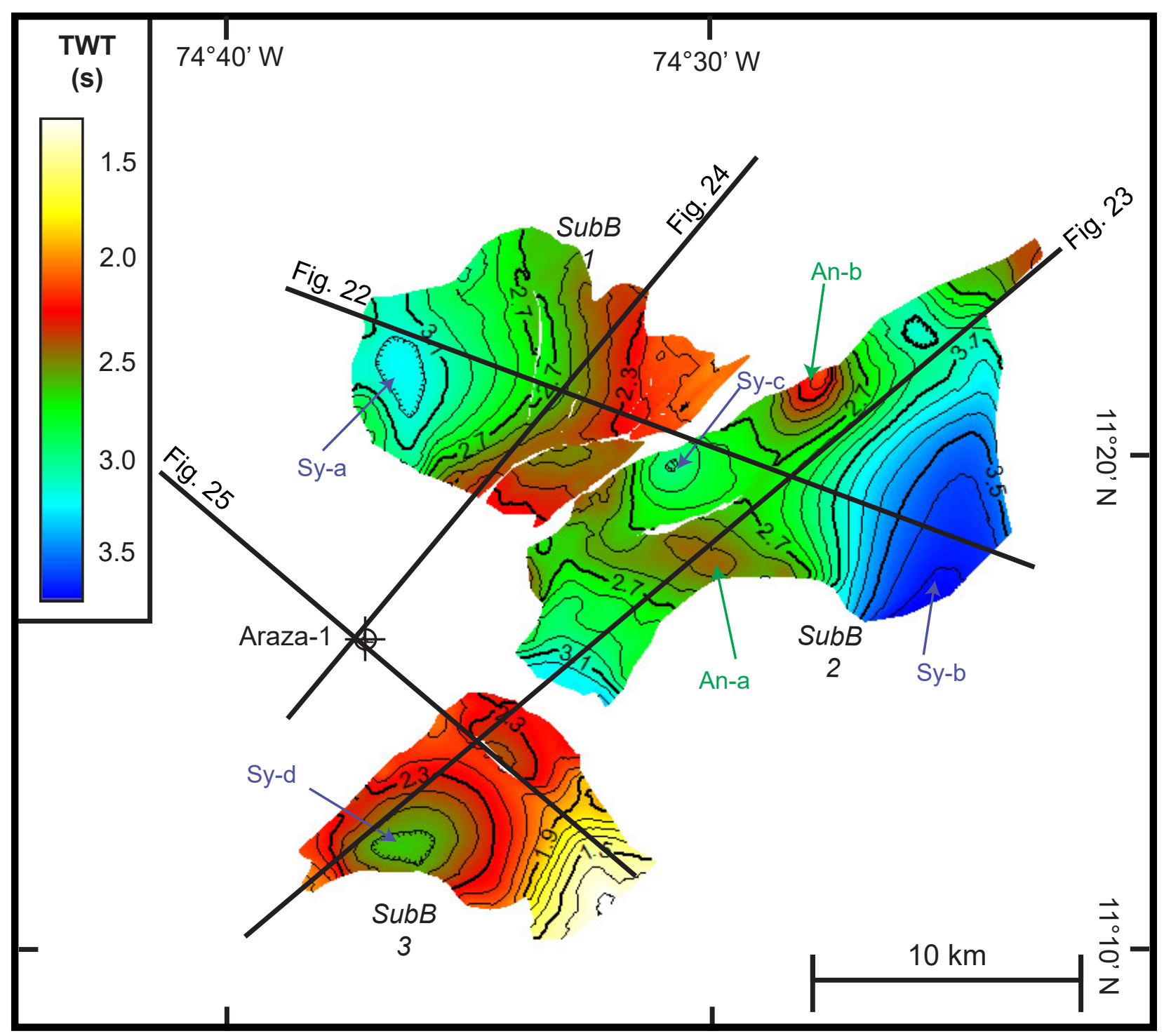

Figure 58. Time structure map at top of Sequence 5 (SB6). Warm colors indicate structural highs and cool colors lows areas. Contour interval 0.1 seconds (TWTT). Anticlines (An) and Synclines (Sy) are labeled. 


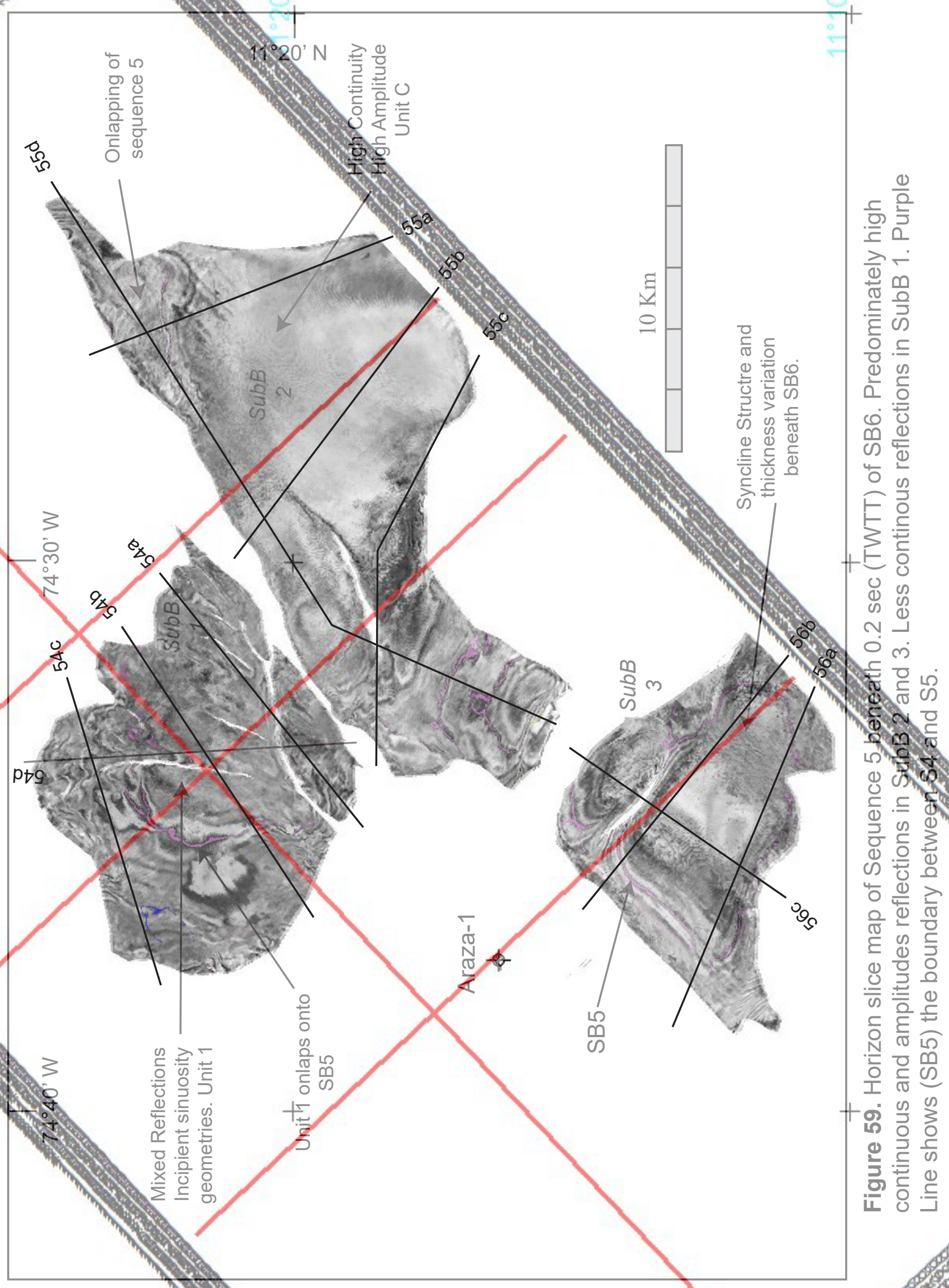




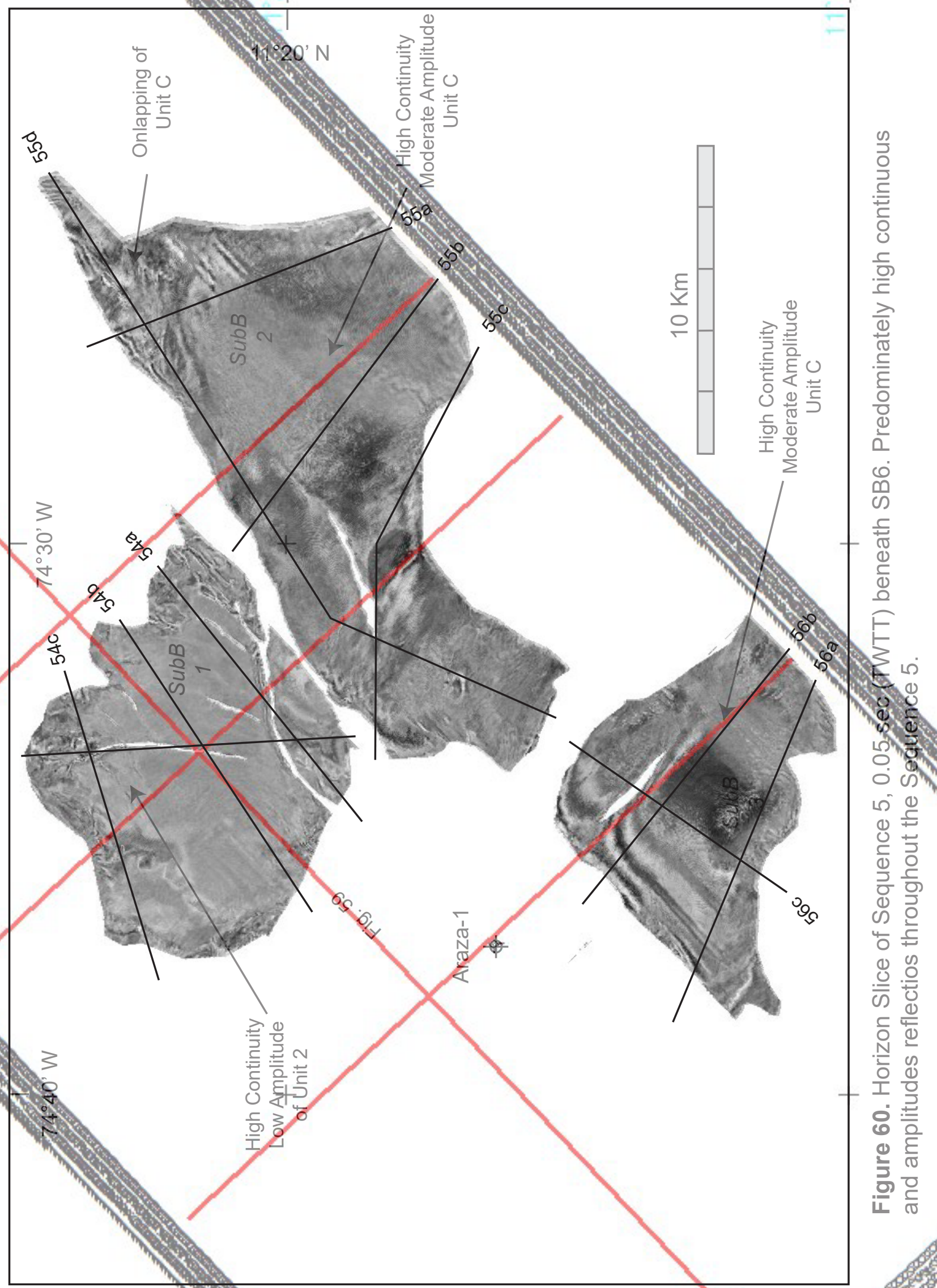




\section{Sequence 6}

Sequence 6 is bounded of the Bahía Basin at its base by SB6 and at the top by the UMU. The basal reflections are concordant over SB5 in all three basins (Figures 54 - 56). The upper reflections are eroded by the UMU. The central part of sub-basin 2 shows the thickest portion of sequence 6 (Figure 55). The unit is completely eroded across the Araza High (Figures 24, 25).

Seismic facies are similar to S5. High continuity characteristic of the sequence in the Bahia Basin. In sub-basin 1, the sequence is characterized by good continuous and high amplitude reflections (Figure 54). In sub-basin 2, wedge geometries thicken to the southeast (Figure 55), keeping reflection facies to sub-basin 1. In sub-basin 3, less continuous reflections with low amplitudes are present, in contrast to the seismic facies of the other sub-basins (Figure 56).

\section{WELL ANALYSIS}

Araza-1, the only well in the study area, was drilled along the crest of a structurally high block (Figures 19, 20). A prominent truncating unconformity is present overlying the potential reservoir sands. The exploration target in this well was geophysics anomalies interpreted in 2D seismic. The well penetrates all three tectono-sequences and reaches 13,300 feet of Total Depth (TD). Reliable GR and resistivity curves were recorded from 2,800 feet to TD. Duarte-Forero et al. (2008) summarized the ages of the area for Recent to Oligocene. As described above, the correlation of the well result into the three subbasins is difficult. 
The section is characterized generally in TS2 and TS3 by abundant upward coarsening packages, capped by flooding surfaces; TS1, in turn, is characterized by interbedded low and high GR package (Figure 61). Each of TS are described here in detail.

$\underline{\text { TS1 }}$

TS1 was divided into five informal logs units (TS1.1 - TS1.5) between 13,300 and 7,060 feet (Figure 61). TS1.1 extends from 13,300 to 12,825 feet, and It is characterized by shales interbedded with thin sandstones (less than 5 feet thick), all of which in HST (Figure 61). The top of TS1.1 has a higher value on the GR, interpreted to a Maximum Flooding Surface (MFS). TS1.2 is between 12,825 and 11,500 feet, and is characterized by an upward coarsening (HST), overlain by continuous low GR values (Figure 61). This unit interpreted as a package of sandstones interbedded with mudstones. The resistivity of the upper 500 feet is up to $16 \mathrm{Ohm}-\mathrm{m}$ values, the highest resistivity values in the well associated to gas shows. TS1.3 extends from 11,500 to 10,360 feet, and is characterized by a package of mudstones interbedded with some limestones associated to TST (Petrobras, 2008). It is capped by a sharp increase in GR values that is interpreted to correspond to a MFS (Figure 61). TS1.4 ranges from 10,360 to 7,950 feet. It is characterized by stacked packages, coarsening upward sandstone (HST) averaging 100 feet thick; in the upper part, section becomes finer upward (TST). It is bound by an abrupt high GR value MFS on the top (Figure 61). TS1.5 extend from 7,950 to 7,060 feet, and is composed by finer sediments with small upward coarsening packages all of which in HST. In general, TS1.5 becomes more shale-rich upward (Figure 61). 
$\underline{\text { TS2 }}$

TS2 is between 5,210 and 7,060 feet and has six informal units. TS2.1 is characterized by high GR package represented as fining upward (TST) siltstones to shales, with 40-foot thickness (Figure 61). It extends from 7,060 to 6,875 feet. At top is a high gamma ray spike, corresponding to a MFS. TS2.2 extends from 6,850 to 6,675 feet and is characterized by a sandy at the base with, interbedded with shale package. The unit becomes finer-grained upwards (TST). At top, an abrupt high GR value (MFS) caps the unit (Figure 61). TS2.3 is characterized by a 200 -feet shale package interbedded with some sand and silts, all of which a HST. It courses upward from shale to siltstone, and is bounded at the top by FS (Flooding Surface) (Figure 61). TS2.4 is between 6,125 and 5,675 feet and is characterized by three packages upward coarsening capped by a FS. The lower package is an upward fining 120-feet capped by a MFS, all of which a TST. The upper package has three internal coarsening upward package capped by a FS. It represents the HST (Figure 61). The TS2.5 extends from 5,675 to 5,210 feet and is characterized by an upward fining shale package at the base separated by MFS with a coarsening upward package from shales to sandstones (The coarser grain as GR recorded in TS2). The top is truncated by a major erosional surface, that is the upper Miocene unconformity (UMU) (Figure 61).

$\underline{\text { TS3 }}$

TS3 extends from the top log (2800 feet) to 5220-foot depth composed of interbedded shale, silts, and sands of 20 to 50 feet in thickness. Some upward coarsening patterns can be discerned in the lower part of the interval. In the shallower part, all of these patterns 
suggest a shallow to marginal marine setting in a HST, with the stacking of parasequence in shoreline (Figure 61).

\section{Biostratigraphy}

The biostratigraphy data gathered from the internal ECOPETROL report subdivide the well into eight foraminifera biozones, as originally defend by Berggren et al. (1995) (Figures 10, 61).

The P21 zone between 13,370 and 12,840 feet, is limited by the last appearance of the Globorotalia optima. This zone correlates with Unit T1.1 and is from the late Oligocene age (Rupelian). The presence of agglutinated foraminifera is reported, characteristic of turbidite deposits (Figure 61).

The P22-M3 zone is defined by the last appearance of Catapsydrax dissimilis and is between 10,920 and 12,850 feet. This biozone is correlated to unit T1.2 and the lower part of T1.3. It dates late Oligocene and the early Miocene, and is the zone with the lowest sedimentation rate within the well (Figure 61). Agglutinated foraminifera, with planktonics, were described within this zone, suggesting turbidite deposits.

The M4-M6 zone overlies P22-M3, and is defined by the last appearance of Praeorbulina spp. This zone is between 8,950 and 10,920 feet and correlates with the upper part of T1.3 and the lower part of T1.4. It extends from the middle Burdigalian age to middle Langhian (Figure 61). The planktoncs, together with some agglutinates, are the most frequent within the interval, assuming possibly continued deposition in turbidite sediment water (Figure 61). 
The M7-M11 zone, defined by the last occurrence of Globigerina mayeri, is limited between 6,220 and 8,650 feet. This zone comprises the upper part of TS1.4 to the top of unit TS2.3. Its age is constricted by the upper part of the Langhian and the Serravallian. The lower part is characterized by the presence of planktonics together with agglutinates, which toward the top varies due to the presence of benthonics and the lack of agglutinates (Figure 61).

The M12-M13a zone is the last zone of TS2, represented by the last appearance of Bolivina floridana. It is located between 5,090 and 6,220 feet and correlates with units TS2.4 to TS2.6. The lower part contains a greater amount of planktonic fauna with benthonic species increasing upward, like the Bolivina (Figure 61). The top of M12-M13a is ended by the late Miocene and early Pliocene regional unconformity and is overlaying by the PL2 zone (Figure 61). This zone is characterized by the last appearance of the Globorotalia margaritae (Figure 61).

In summary, TS1 in Araza-1 has the coarsest grains of the section (Figure 61) in TS1.2 and TS1.4, associated with high amplitude with fair continuity reflections (Figure 62). The boundary is clearly identified in seismic in contrast to the lack of biostratigraphy and lithostatigraphy elements at the top of TS1. TS2 is the finest grains section in Araza-1. This contrast to the abundance of neritic benthonic foraminiferous defined by DuarteForero et al. (2008). The morphology changes in the bathymetry associated by transpression and transtension may be related to abundant neritic biostratigraphy record. The SB interpreted in seismic coincides with the MFS and FS indicated in Araza-1 (Figure 61). The HST episodes, is likely associated to sediment input pulses during Bahia Basin sedimentary-fill. TS3 represent a continuous fine input sediment subsequent, represented 


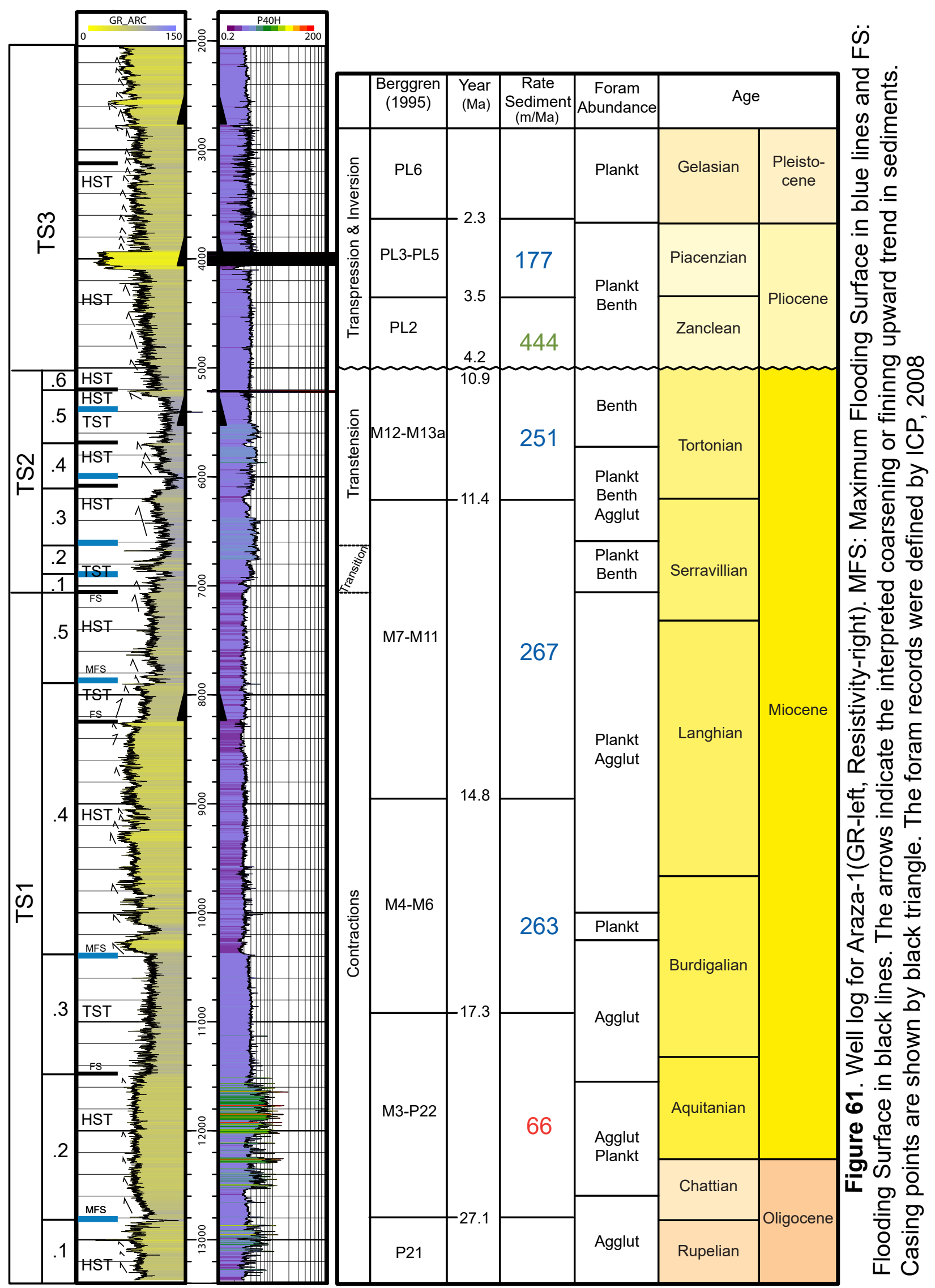




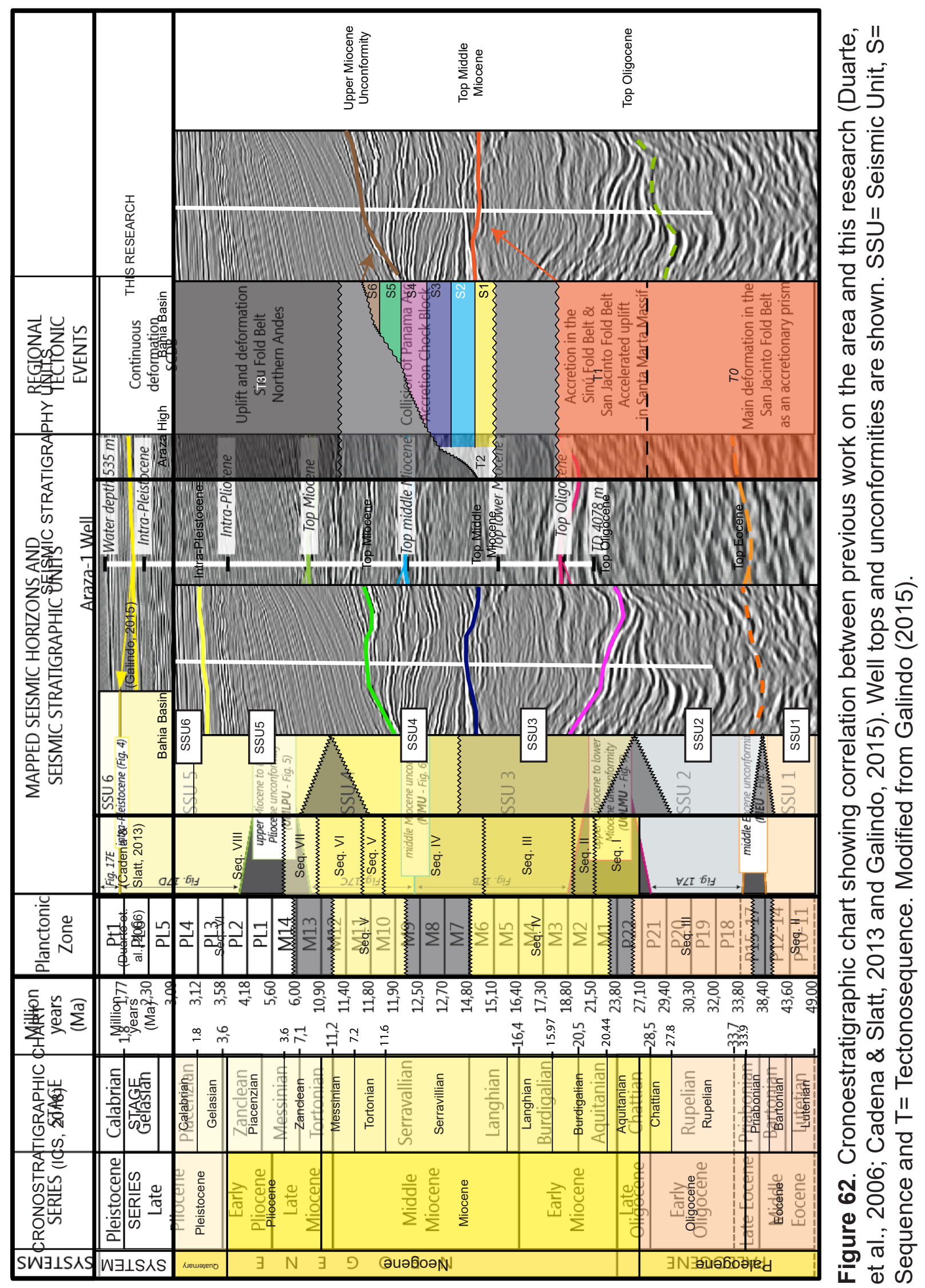


by high continuous and amplitude reflections during the early Pliocene to Recent (Figures $61-62)$.

The UMU major unconformity at Bahia Basin is clearly identified in the seismic data (Figures 17 - 20) and the Araza-1 well (Figures 10, 61 - 62). UMU eroded the youngest sequence deposited on TS2 due to a structural reactivation of an inversion of the Bahia Basin in the early Pliocene. Araza-1 foraminifera biostratigraphy shows a prominent hiatus of 6 Myr in duration, represented by biozone jump from M12 - M13a to PL2

This boundary is interpreted as a big tectonic uplifting event in the northern part of South America. Other studies reported the unconformity in different areas of the CCM; (Duarte et al., 2006; Alfaro and Holz, 2014a) reported UMU in San Jacinto and the Sinu prism and Ramirez et al. (2015) in the Guajira Basin.

\section{DISCUSSION}

The Bahia Basin area has developed in a complex area, affected by oblique stress, subduction, inversion, gravitational faults, and erosion.

The research walks through a detailed evolution of each sequence described in TS2 and later defines a general evolution associated with tectonic events occurred in the Colombian Caribbean Margin (CCM) during the Neogene.

\section{Tectonic evolution}

The Bahia Basin has developed in three main phases: Contraction (Thrusting), Transtension and sediment Filling, and Transpression and Inversion. All these phases have been characterized by structural features described in detail above. 


\section{Contraction}

This phase is defined by the deformation that occurred along TS1 by thrust faults and folds that strike southwest to northeast. This phase precedes the formation of Bahia Basin (Figures 17 - 21). Galindo (2015) interpreted TS1 as part of accreted terrains of the Sinu - San Jacinto Thrust belt, dating from the Eocene to middle Miocene (Figures 4, 6).

\section{Transtension and Filling (early Miocene - middle Miocene)}

The phase of opening and filling of the Bahia Basin is record by six sequences. This phase is associated with the abruptly shifting movement of the Caribbean Plate during the early Miocene (Pindell and Kennan, 2009) (Figure 5). The displacement on strike-slip faults $\mathrm{A}, \mathrm{B}$ and $\mathrm{C}$, started during the early Miocene - middle Miocene, creating three main depocenters or sub-basins (Figure 63). Older thrusting faults from TS1 were reactivate as normal and transfer faults that affect deposition.

Thus, sub-basins 1 to 3 were the main accommodation areas, where the sediment arrived. Faults A, B, and C created paleo-highs of exposed TS1. S1 to S6 represent the filling event and the transition of high erosive channels to draped sediments in the intraslope basin. This sedimentation process is similar to the fill and spill deposits in irregular intraslopes described by (Prather et al., 1998; Prather, 2000).

Inversion, Erosion, and Gravitational Fault (Pliocene to Recent)

The Pliocene was affected by a series events; The major displacement of the Bahia Basin, squeezing the northern part of the area, and represented by a positive flower in the Araza High, uplifting TS2. These events are related with inversion time in which TS2 depocenters are the new topography of TS3 (Figures 17 - 25). 


\section{Stratigraphic - structural evolution of the Bahia Basin}

The structural evolutions of the Bahia Basin for TS2 can be evaluated by looking at the isochrons of sequence 2.1 to 2.5 together. The changes in the morphology of the basin can be estimated during deposition from the thickness changes between sequence within sedimentary basins that developed associated with strike-slip basins. Basins common change through overall slope depending upon the changing stress regimens both transpression and transtentions.

S1 was deposited in a pre-existing bathymetry within a slope, that was inherited from TS1. Three districts depocenters are present in the sub-basins (Figure 63). The thickest sediments are adjacent to Fault B in sub-basin 2 reaching 0.9 seconds (TWTT). In the central part, a subtle paleo-high (Figure 63b) divided the sub-basin into two areas to the north and west. Two smaller iso-thicks depocenters are to the northwest of sub-basin 1, and to the north of sub-basin. Depositional elements consist of erosional and some aggradational channel-fill as a sediment bypass and fill area.

S2 is the thinnest sequence of the TS2 (Figure 64b). Three prominent depocenters characterize the sequence along the basin. In sub-basin 1, the depocenter has migrated to the south, where it is now adjacent to Fault B (Figure 64a, b). The depocenter in S1 has evolved into bathymetric high in S2, suggesting a local transpression (Figures 34, 64b). In sub-basin 2 and 3, the sediment-fill of the S1 main depocenter continues in S2

(Figure 35, 64b). The drainage direction varies from the NW in S1 to the NE in S2 and consist of erosive and aggradational channel-fill, keeping a sediment bypass and fill area (Figure 35). 
In the S3, the major depocenter in sub-basin 1 likely extended to sub-basin 2 (Figure 64c). Adjacent to the major frontal normal fault (Figure 23), the thickness variations are the initial stage of reactivated normal fault movement of inherit thrust faults in TS1 (Figure 41, 64). In sub-basin 3, incipient normal faulting (Figure 41), associated with that reactivated faults, begins to develop. Sedimentation continues developing NE erosive channels in sub-basin 1 and more aggradation in sub-basins 2 and 3 (Figures 40 - 42). In S4, a distinct south shift in the depocenter occurred to sub-basin 2 (Figure 64d). Subbasin 1 a paleo-high develop assosciated with transpression along Fault $A$; the main depocenter migrated to the south (Figure 64c, d). In sub-basin 2 increase in the size of the depocenter indicates increase subsidence, likely associated with increased transtension (Figure 64d). In sub-basin 3, the filling process continues the same drainage trend (Figure 49, 52 - 53). In sub-basin 1 erosive channel-fill continue dominate the depositional process. In sub-basins 2 and 3, channel-levee complexes sedimentation filling is predominating (Figures 48 - 49).

In S5, the depocenter in sub-basin 2 shifted to the south (Figure 64e). The connection of sub-basins 1 and 2 is restored. Sub-basin 3 shows increased thickness in sequence 5 in the central part as a result of change in location of subsidence (Figure $64 \mathrm{~d}, \mathbf{e}$ ). The main sedimentation in sub-basin 1 are channel-levee complexes, while draped sediments with channel-levee complexes dominate the sub-basins 2 and 3 deposition (Figures 54 - 56).

S6 is the continuity of the sediment scheme of sequence 5 culminating the filling process of Bahia Basin. The sequence is affected by the initial transpression and inversion stage post-Miocene (Figures 54 - 56). 


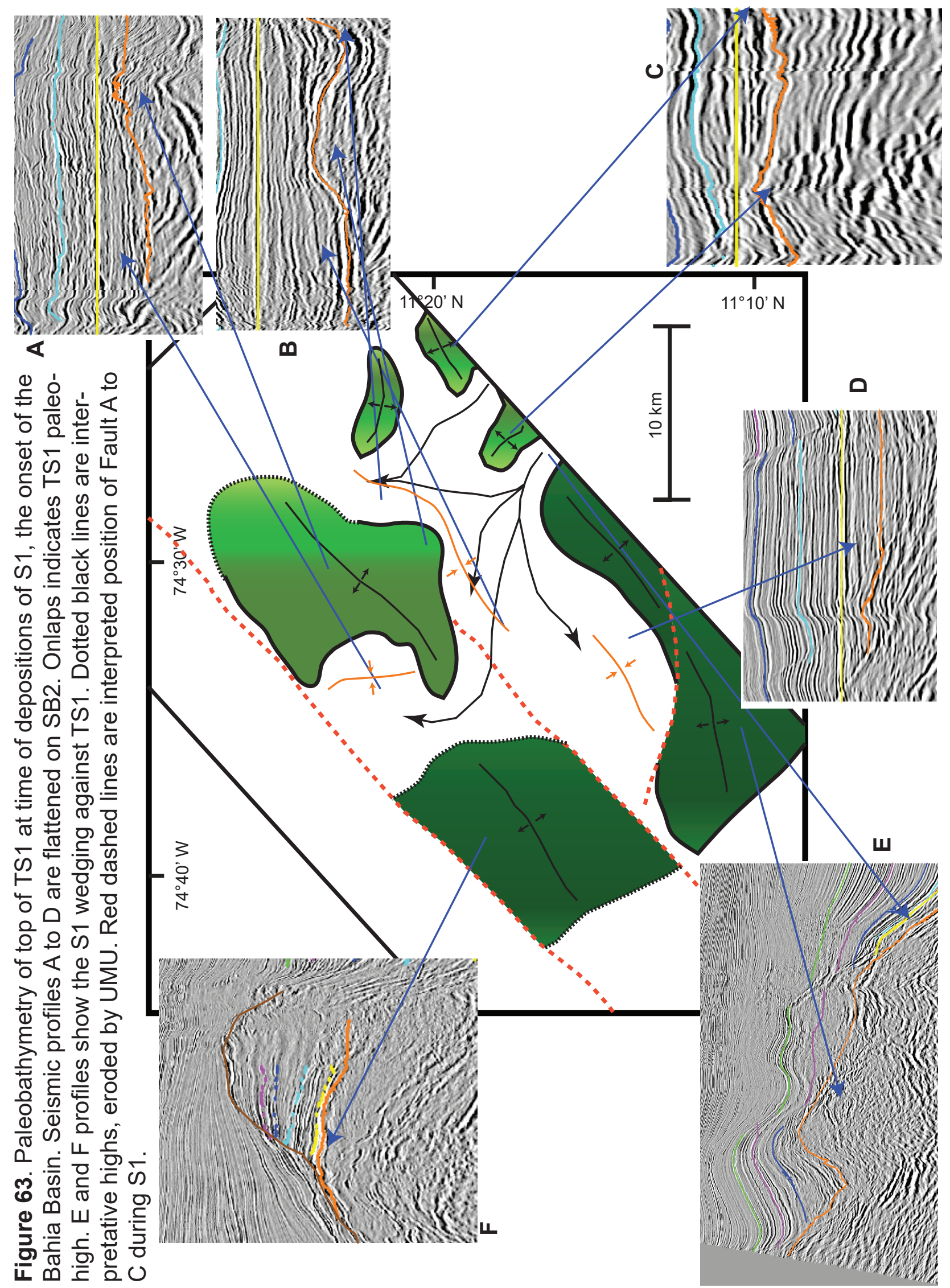




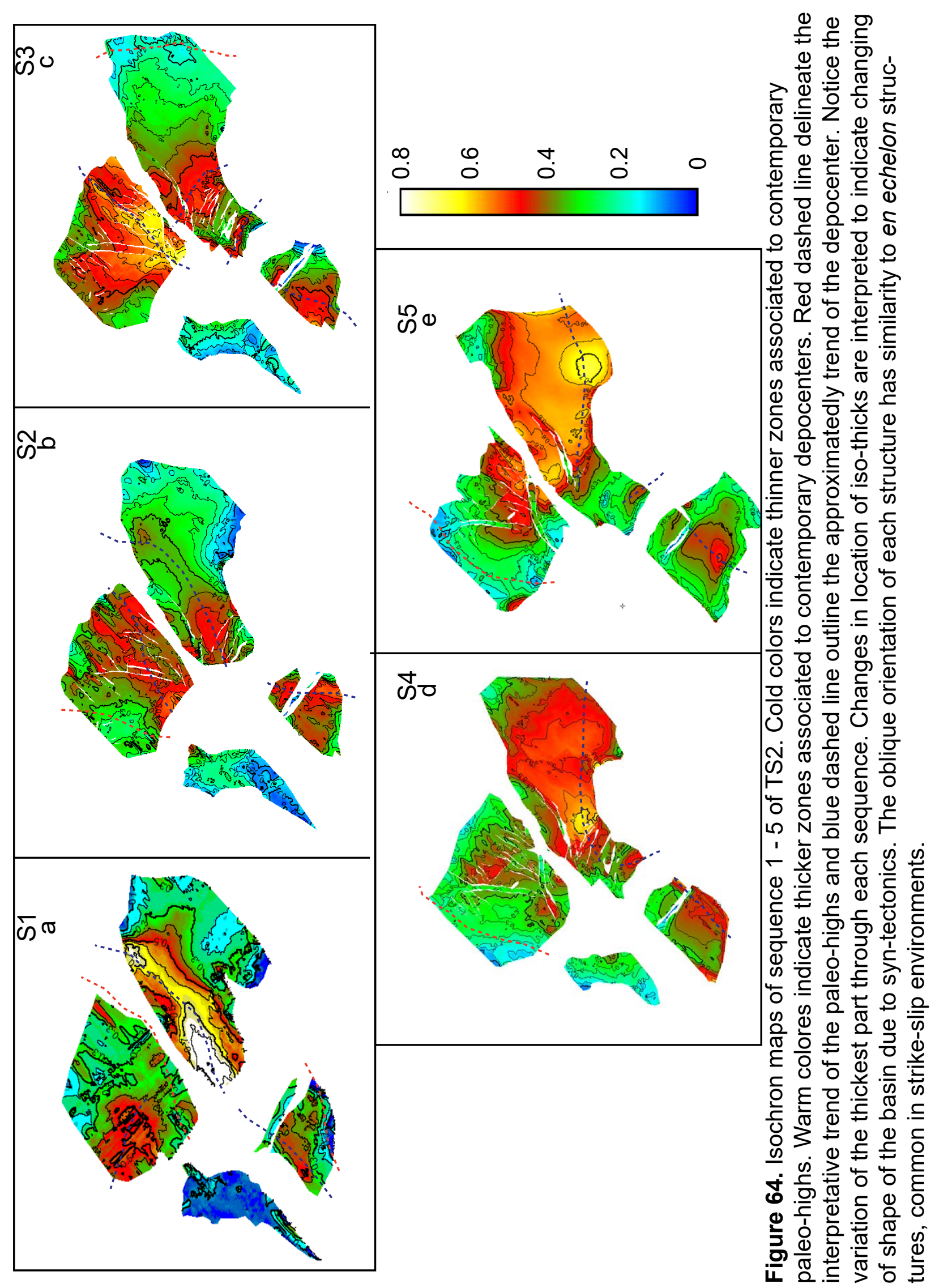


In summary, the Bahia Basin began to develop after a contractional event in TS1, which created the first main sub-basin of the Bahia. As the area became more transtentional, accommodation developed that allowed for the deposition of TS2. Slight deformations represented by numerous onlaps within the sequence prove subtle internal transpression deformation into a great transtensive stage. These minor folds minimally affected deposition. Continuous sedimentation during TS2 is markedly by variation from erosive and amalgamated channels at S1, to channel-levee complexes on top of S5 and S6. The transtensional and sediment-fill ended by the prominent early Pliocene deformation that uplifted the Bahia Basin strongly eroded the upper sequence (S6) of TS2.

\section{Shale Tectonics}

Shale tectonics in the northern part of the Bahia Basin have been reported by Galindo (2015). Mud diapirism is the result of over-pressured mud units and intruded with a mixture of different fluids (water, gas, oil, or combinations). In the SCDB, the shale units are thicker in the core of the anticlines, creating dome-shape forms (Galindo, 2015). In the Bahia Basin, some mud volcano are present along Fault $A$ that reaches the surface (Figure 65). These mud diapiris are associated with gas accumulation and expulsion using the fault pathways, as an escape route (an indicator of gas generation in the area). Nonetheless, there is not evidence that shale diapirism affected sedimentation during the Miocene.

\section{Petroleum System Elements: Assessment of Hydrocarbon Potential}

Each element in the petroleum system evaluated bellow using an informal ranking of risk (Low, Medium, and High). 


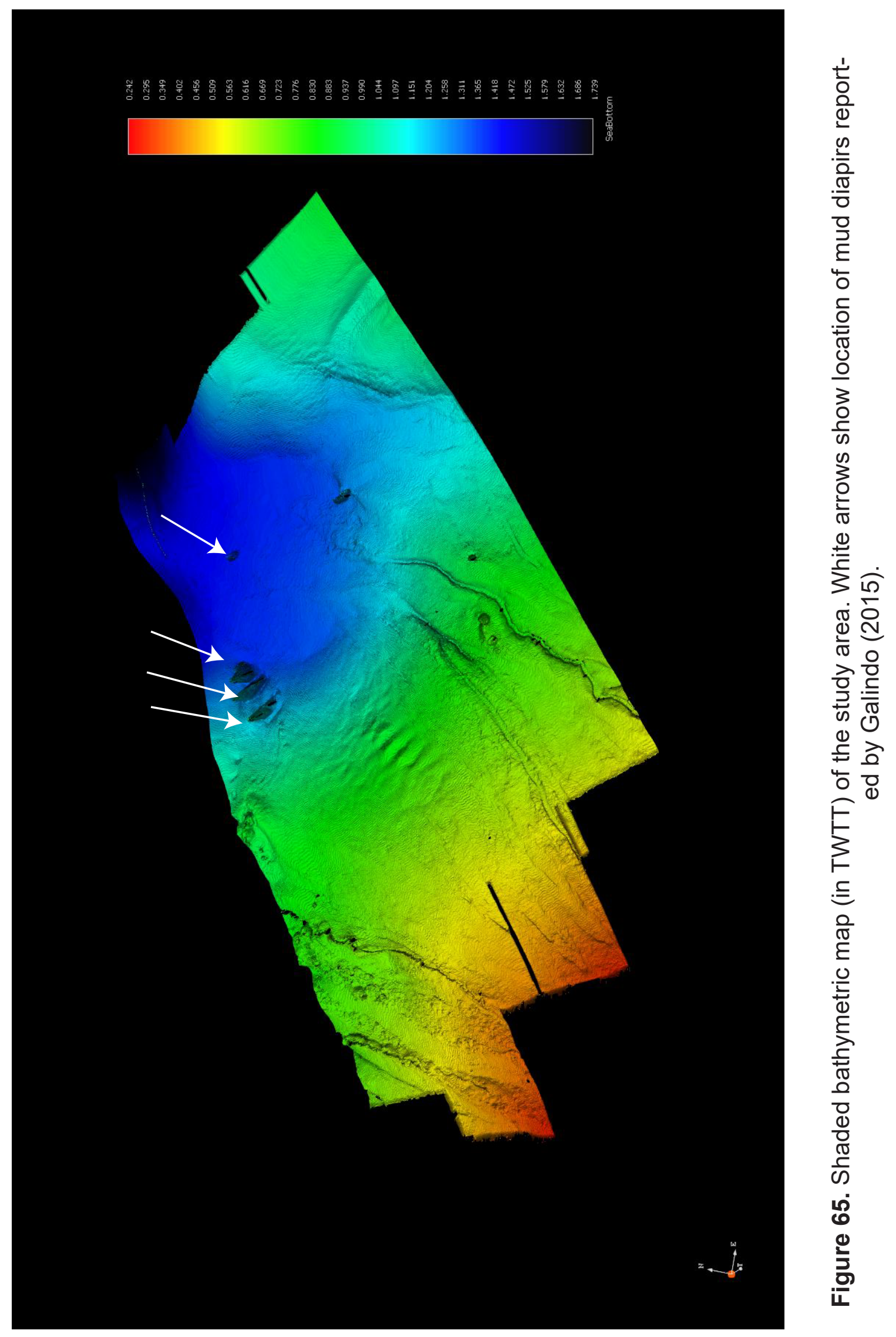




\section{Source Rock}

The best possible source rock in the Caribbean is related to onshore late Cretaceous strata reported by (Duque-Caro, 1991; Flinch, 2003; Nino, 2005). The Cansona Formation, is composing siltstones, green, grey, and black mudstone and some greywackes, are present in the San Jacinto and Sinu Belts (Guzman, 2007). The lower member has an average of $3.67 \%$ of TOC (Total Organic Carbon) reported, type-II kerogen with an $\mathrm{HI} 435 \mathrm{mg} \mathrm{HC} / \mathrm{g}$ (Nino, 2005). The $\mathrm{T}_{(\max )}$ is 435 (Nino, 2005), considered at the limit between the immature and early mature in thermal maturity for oil generation.

Offshore evidence of source rock is indicated by oil seeps, wells, and piston cores. High concentration of diamantoids associated with Cretaceous origin generated by type-II Kerogen might support evidence of the Casona Formation thermal generation in the area (Martinez et al., 2015).

Possible secondary source rocks Oligocene mudstone (El Carmen formation), reported in the San Jacinto - Sinu belts (Barrero et al., 2008). El Carmen Formation is composed by mainly dark gray fresh claystone (Guzman, 2007). In spite of the lack of geochemical analysis, the lithology descriptions of the mudstones evidence a potential source rock Oligocene. The source rock is evaluated as Medium Risk

\section{$\underline{\text { Reservoir }}$}

The Araza-1 well penetrated sand in all TS. In lower levels of TS1, sands are present deeply. In TS2, GR indicates serrate pattern of interbedded mudstone and siltstones coarsening upwards. Nevertheless, the Araza High is likely the most distal zone of the Bahia Basin and might be interpreted as a sediment bypass zone. This premise can support the thinner beds of S1 to S5 drilled in the area (Figures $24-25)$. Sands are 
frequently associated with channels and the strong channeling facies pattern described on TS2 inferred a reservoir potential. The Barranquilla Well, located $30 \mathrm{~km}$ southwest from the Araza-1 well, reported $230 \mathrm{~m}$ of sandstones dating from the Late Miocene (Jones, 2000; Martinez et al., 2015). The reservoir is assessed as Low Risk.

\section{Seal}

The sequences have several MFS described in the Araza-1 well (Figure 62). High spikes of GR indicate clay-rich sediments, with high potential impermeable rocks in TS2. Additionally, TS3 is described as a shaly unconfined hemipelagic unit in the internal ECOPETROL report (Figure 5). The Seal is judged as Low Risk.

\section{Trap}

Wilcox et al. (1973) stated that "en echelon folds are the most important structures of potential value for trapping hydrocarbon in most strike-slip zones," similar to the structure setting of the Bahia. The most important structures in TS2 are the Anticline A (Figures 14 - 16) limited by two faults in the north and south, and with the Anticline $B$, which is a three-way closure against Fault B. However, the area of this traps is too small to considered as potential. In addition, the high amount of faulting decreases the quality of the traps and increases the pathways escaping to the surface, which is assessed as Medium Risk.

\section{Migration}

Cretaceous and Oligocene oil seeps are present overall the Caribbean Margin, indicating a generating petroleum system at present. Plus, the DHI (Direct Hydrocarbon Indicator) flat spot shown in the An-a supports gas generation in the basin (Figure 66). The 


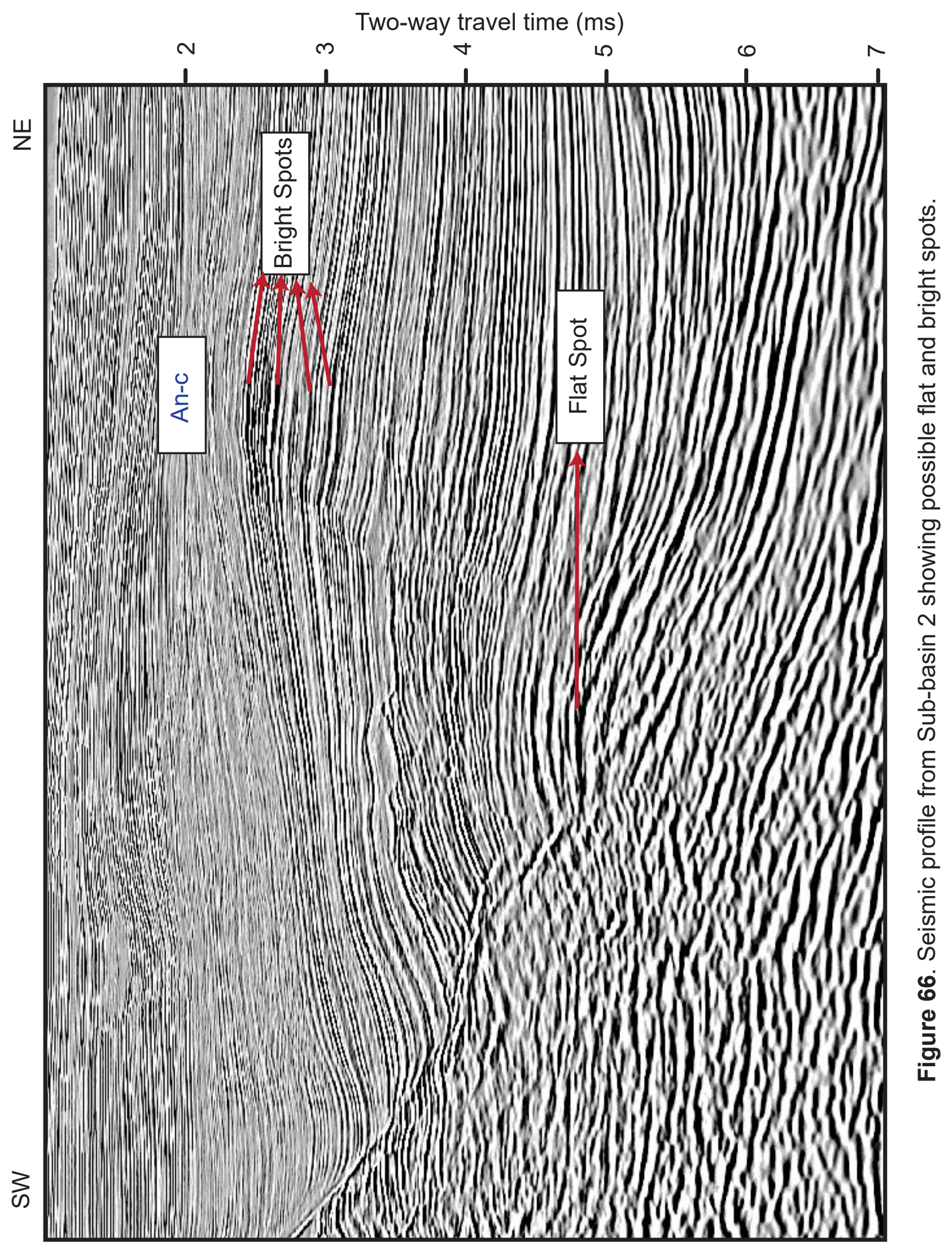


reactivated faults in the Bahia create pathways to connect the deeper units (rich in Organic Matter) to fill the shallow structures. The Migration is evaluated as Low Risk.

\section{Timing}

Recent hydrocarbon generation, demonstrated as multiple seismic gas evidence (Figure 68), indicates an active petroleum system. However, current activity of the strike-slip faults (Faults A, B, and D) affects considerably the efficiency of the traps (folds) and seals (clay-rich TS2 and TS3). For said reasons, the timing has been evaluated as high risk.

\section{$\underline{\text { Considerations }}$}

Hydrocarbon potential merely focuses on thermal generation without considering microbial generation. Discoveries, like Kronos-1, Purple Angel-1, and Gorgon-1 (Figure 2), are microbial gas discovers. Orca-1 is a mix between thermal and microbial gas. However, the high rates of sedimentation in Negoene in the Sinu Offshore basin differs from the lower sedimentation ratio in the Bahia Basin, constraining the microbial generation in the area. Some DHI (Direct Hydrocarbon Indicator) markers (Figure 68) support the gas evidence in the area, considering the Bahia Basin as a potential gas zone.

\section{CONCLUSIONS}

- The Bahia Basin developed in three regional tectonics phases. The contractional event deformed the sediments in TS1. Next, a transtensional phase created by the Bahia Basin TS2 and the sediment deposition in them. Finally, a major transpressional, uplifting the previous depocenter of TS2. 
- The Bahia Basin was filled by sediments that likely were six third-order sequences. The basin was characterized by subtle transpression deformation, which affects deposition. The Bahia Basin is filled by erosive channels in confined slopes that evolves to a channel-levee complexes and draped mudstones in unconfined slopes.

- Oblique structures along the basin regarding strike-slip faults evidence the continuous oblique deformation from the middle Miocene to Recent periods.

- The Araza High, where the Araza-1 well was drilled, is the distal area of the thickest sedimentation of TS2. However, the prominent unconformities interpreted on the seismic data allow constraining the TS2 age between the middle Miocene and late Miocene periods.

- The channeling-fill deposit in TS2 makes the Bahia Basin an attractive, potential high-quality reservoir zone. Petroleum elements are present which makes the Bahia Basin an interesting area to evaluate the hydrocarbon potential of an intraslope basin. 


\section{REFERENCES}

Alfaro, E., and M. Holz, 2014a, Review of the chronostratigraphic charts in the Sinú-San Jacinto basin based on new seismic stratigraphic interpretations: Journal of South American Earth Sciences, v. 56, p. 139-169.

Alfaro, E., and M. Holz, 2014b, Seismic geomorphological analysis of deepwater gravity-driven deposits on a slope system of the southern Colombian Caribbean Margin, v. 57, 294-311 p.

Barrero, D., A. Pardo, C. Vargas, and J. F. Martinez, 2008, Colombian sedimentary basins: nomenclature boundaries and petroleum geology, a new proposal, $\mathrm{ANH}$.

Berggren, W. A., D. Kent, C. C. Swisher III, and M.-P. Aubry, 1995, A Revised cenozoic geochronology and chronostratigraphy: Geochronology time scales and global stratigraphic correlation, v. 54, 129-212 p.

Cadena, A. F., G. A. Romero-Otero, and R. M. Slatt, 2015, Application of stratigraphic grade concepts to understand basin-fill processes and deposits in an active margin settings. Magdalena Submarine Fan and associated fold-and-thrust Belts, offshore Colombia, in C. Bartolini, and P. Mann, eds., Petroleum geology and potentianl of the Colombian Caribbeaan Margin, v. 108, AAPG Memoir.

Campbell, C. J., 1965, The Santa Marta wrench fault of Colombia and its regional setting.

Duarte-Forero, J. A., M. Pulido, and O. Mantilla, 2008, Reporte interno Ecopetrol.

Duarte, L. M., J. A. Rizzi, M. A. Toledo, J. Reistroffer, J. Buitrago, E. Avella, C. Guerrero, and M. Suarez, 2006, Estratigrafía y controles sedimentarios de la cuenca costa afuera en el Caribe Colombiano: 9th Simposio Bolivariano - Exploración Petrolera en las Cuencas Subandinas. 
Duque-Caro, H., 1991, Contributions to the geology of the Pacific and the Caribbean coastal areas of Northwestern Colombia and South America: Ph D thesis, Princeton University, $132 \mathrm{p}$.

Ercilla, G., B. Alonso, F. Estrada, F. L Chiocci, J. Baraza, and M. I. Farran, 2002, The Magdalena turbidite system (Caribbean Sea): present-day morphology and architecture model, v. 185, 303-318 p.

Escalona, A., and P. Mann, 2011, Tectonics, basin subsidence mechanisms, and paleogeography of the Caribbean-South American plate boundary zone: Marine and Petroleum Geology, v. 28, p. $8-39$.

Estrada, F., G. Ercilla, and B. Alonso, 2005, Sinuosity peaks on the channel IA of the Magdalena fan: faults and avulsions.

Flinch, J. F., 2003, Structural evolution of the Sinu-Lower Magdalena area (Northern Colombia): The Circum-Gulf of Mexico and the Caribbean: Hydrocarbon habitats, basin formation, and plate tectonics.

Flinch, J. F., and V. Castillo, 2015, Record and constraints of the eastward advance of the Caribbean Plate in northern South America, in C. Bartolini, and P. Mann, eds., Petroleum geolgoy and ptential of the Colombian Caribbean Margin v. 108, AAPG Memoir, p. 1-10.

Galindo, P., 2015, Transtension and transpression in a oblique subduction setting: evolution of the Bahia Basin, Colombian Caribbean margin, Imperial College London, Unpublished.

Galindo, P., and L. Lonergan, 2015, Transtension and transpression in an oblique subduction setting : evolution of the Bahia Basin, Colombian Caribbean margin: Great Britain, Imperial College London, 1 online resource $p$.

Galindo, P., and L. Lonergan, 2017, Transpressional inversion in the Bahia Basin, Offshore Santa Marta, Colombian Caribbean margin. 
Guerrero, J., 1993, Magnetostratigraphy of the upper part of the Honda Group and Neiva Formation : Miocene uplift of the Colombian Andes: Ph D thesis, Duke University, viii, 108, 87 leaves $p$.

Guzman, G., 2007, Stratigraphy and sedimentary environment and implications in the Plato Basin and the San Jacinto Belt northwestern Colombia, Université de Liège.

Hoorn, C., J. Guerrero, G. A. Sarmiento, and M. A. Lorente, 1995, Andean tectonics as a cause for changing drainage patterns in Miocene northern South America: Geology, v. 23, p. 237-240.

Jones, R. W., 2000, Bioestratigraphy of nine wells offshore Colombia: BP, Internal Report., p. 230.

Kolla, V., R. T. Buffler, and J. W. Ladd, 1984, Seismic stratigraphy and sedimentation of Magdalena Fan, Southern Colombian Basin, Caribbean Sea, v. 68.

Martinez, J. A., J. Castillo, A. Ortiz-Karpf, L. Rendon, J. C. Mosquera, and V. Vega, 2015, Deep water untested oil-play in the Magdalena Fan, Caribbean Colombian Basin, in C. Bartolini, and P. Mann, eds., Petroleum Geology and Potential of the Colombian Caribbean Margin, American Association of Petroleum Geologists.

Mitchum, J. R. M., P. R. Vail, and J. B. Sangree, 1977, Seismic stratigraphy and global changes of sea level, Part 6: Stratigraphic interpretation of seismic reflection patterns in depositional sequence, in C. E. Payton, ed., Seismic Stratigraphy - Applications to Hydrocarbon Exploration, American Association of Petroleum Geologists.

Nino, C. H., 2005, Sistemas petroliferos da parte norte da Bacia de Sinu-San Jacinto, Colombia. Ummaavaliacao geologica e geoquímica integrada., Universida de Federal do Rio de Janeiro.

Ortiz-Karpf, A., D. M. Hodgson, and W. D. McCaffrey, 2015, The role of mass-transport complexes in controlling channel avulsion and the subsequent sediment dispersal patterns on an 
active margin: The Magdalena Fan, offshore Colombia: Marine and Petroleum Geology, v. 64 , p. $58-75$.

Petrobras, 2008, Informe del post mortem del pozo Araza_001, reporte interno.

Pindell, J., and L. Kennan, 2001, Kinematic evolution of the Gulf of Mexico and the Caribbean, in petroleum systems of deep-water basins: Global and Gulf of Mexico experience, 159-192 p.

Pindell, J., and L. Kennan, 2009, Tectonic evolution of the Gulf of Mexico, Caribbean and northern South America in the mantle reference frame: An update, v. 328, 1-55 p.

Prather, B., J. R. Booth, G. Steffens, and P. A. Craig, 1998, Classification, lithologic calibration and stratigraphic succession of seismic facies from intraslope basins, deep water Gulf of Mexico, U.S.A, v. 82, 701-728 p.

Prather, B. E., 2000, Calibration and visualization of depositional process models for above-grade slopes: a case study from the Gulf of Mexico: Marine and Petroleum Geology, v. 17, p. 619-638.

Ramirez, V., L. S. Vargas, C. Rubio, H. Nino, and O. Mantilla, 2015, Petroleum systems of the Guajira Basin, Northern Colombia, in C. Bartolini, and P. Mann, eds., Petroleum Geology and Potential of the Colombian Caribbean Margin, American Association of Petroleum Geologists.

Romero-Otero, G. A., R. M. Slatt, and C. Pirmez, 2015, Evolution of the Magdalena deepwater fan in a tectonically active setting, offshore Colombia, in C. Bartolini, and P. Mann, eds., Petroleum geology and potentianl of the Colombian Caribbeaan Margin, v. 108, AAPG Memoir

Villamil, T., 1999, Campanian-Miocene tectonostratigraphy, depocenter evolution and basin development of Colombia and western Venezuela: Palaeogeography, Palaeoclimatology, Palaeoecology, v. 153, p. 239-275. 
Vinnels, J., R. W. H. Butler, W. D. McCaffrey, and D. Paton, 2010, Depositional processes across the Sinú accretionary prism, offshore Colombia, v. 27, 794-809 p.

Wilcox, R. E., T. P. Harding, and D. R. Seely, 1973, Basic wrench tectonics, v. 57, 74-96 p. 